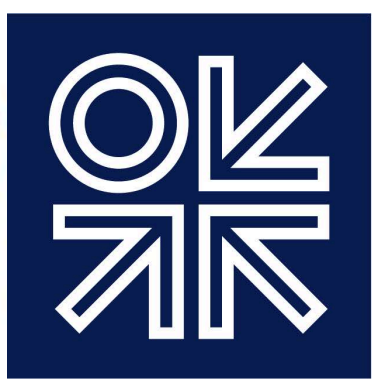

THE OXFORD

INSTITUTE

FOR ENERGY

STUDIES

September 2015

\title{
The Political and Commercial Dynamics of Russia's Gas Export Strategy
}

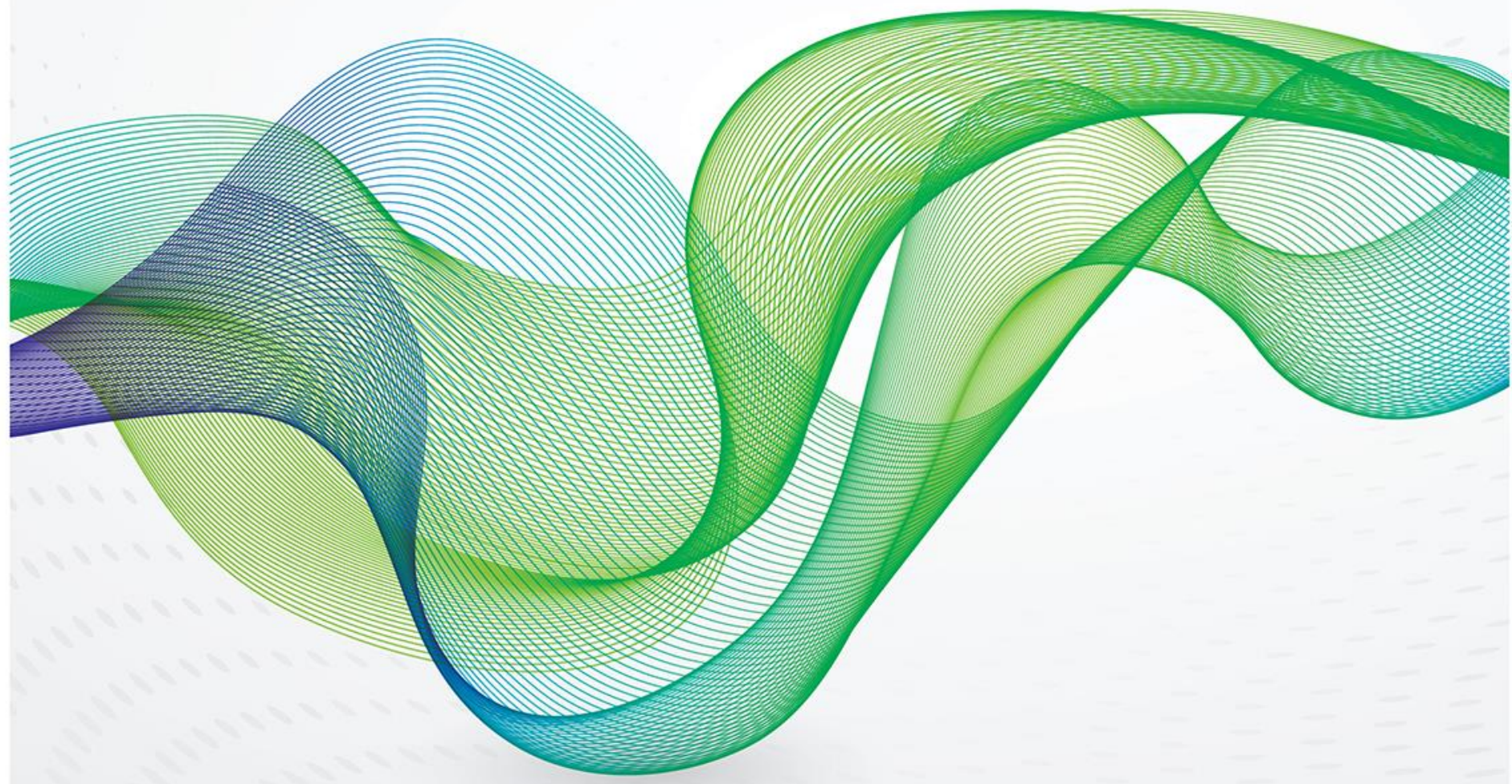



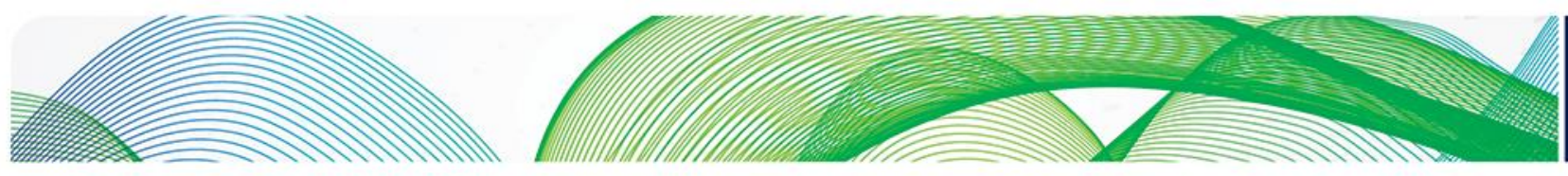

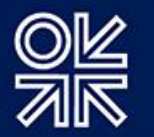

The contents of this paper are the authors' sole responsibility. They do not necessarily represent the views of the Oxford Institute for Energy Studies or any of its members.

Copyright $\odot 2015$

Oxford Institute for Energy Studies

(Registered Charity, No. 286084)

This publication may be reproduced in part for educational or non-profit purposes without special permission from the copyright holder, provided acknowledgment of the source is made. No use of this publication may be made for resale or for any other commercial purpose whatsoever without prior permission in writing from the Oxford Institute for Energy Studies.

ISBN 978-1-78467-039-9

*James Henderson is Senior Research Fellow, OIES \& Tatiana Mitrova is Head of Oil and Gas Department at Energy Research Institute, Russian Academy of Sciences (ERI RAS) 

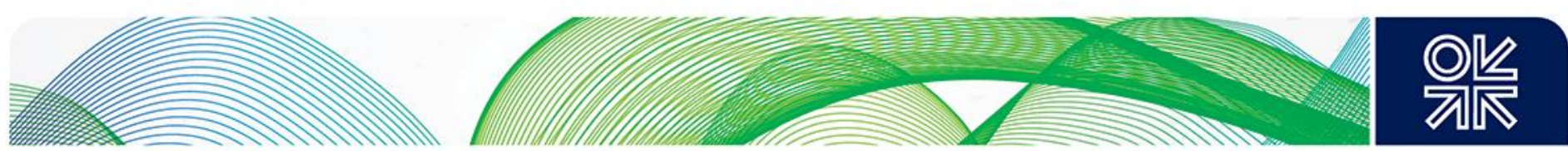

\section{Preface}

Russia has long been regarded as the world's pre-eminent gas producer, both by virtue of its reserves base and the central role played by Gazprom, its state-owned 'gas champion' in the 'matrix' of domestic supply and consumption, and import and export gas trade-flows linking it to Central Asian and Western former FSU states as well as European gas buyers. The construction of this gas network in terms of the sheer scale of physical infrastructure involved and the management of the contractual and political - economic relationships underpinning it, represents a spectacular achievement by any standard. Gazprom, at the centre of this system, has become an important source of state revenue as well as an agent dealing with FSU customers in the sometimes tensionridden post-Soviet landscape.

Markets, even physical commodity markets, do not stand still. As continental Europe followed North America and the UK before it down the path of gas market liberalisation and hub pricing, Gazprom's oil indexed long term contract business model came under siege and has yielded. In its domestic market, the rise of 'independents' has eroded Gazprom's market share to a remarkable extent. European gas market regulatory architecture re-design has clashed with Gazprom's plans to construct 'transit avoidance' pipelines around the Ukraine, with whom it has long running disagreements on gas pricing. The prospect of high demand growth for gas in the European gas generation, against which Gazprom invested billions developing the giant Yamal field complex has turned out to have been a mirage. Slow post financial crisis Eurozone economic growth and the zealous pursuit of renewable energy policy on the part of Brussels has resulted in stagnant demand for Russian gas pipeline imports and, following the Russia-Ukraine tensions of recent years, a desire to diversify away from Russian gas.

Russia's resulting campaign to access the Asian and specifically Chinese market, whilst sound in principle, has become bogged down in disagreements on contract pricing and route preference. The collapse in oil prices from late 2014 has crimped Gazprom's cashflow outlook and narrowed its room for manoeuvre. The impending surge in Australian LNG exports and later this decade the expected surge in US LNG as a consequence of the shale gas revolution, add to the challenges of Gazprom in Europe and Asia.

This paper adds to the considerable listing of books and papers produced by the Oxford Institute for Energy Studies Natural Gas Research Programme on the subject of Russia, Gazprom and its interaction with the global gas system. In addition to the looking at its emerging challenges and threats, the paper also offers unique insight into the ability of Gazprom to respond to its changing business environment, whether strategically or reactively.

Howard Rogers

Oxford 2015 

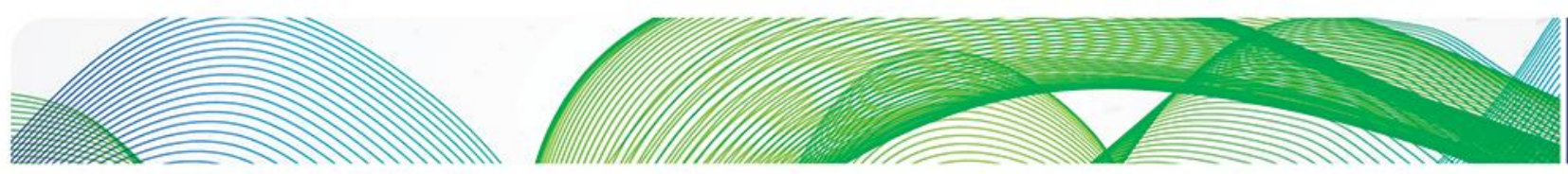

\section{O傮}

\section{Acknowledgements}

We would like to thank our colleagues at OIES and ERI RAS for their help with this research and to those who also assisted by reviewing this paper. In particular we am very grateful for the support and comments provided by Howard Rogers, Jonathan Stern, Simon Pirani, Katja Yafimava, and Anna Galkina whose contributions were all vital to the completion of our analysis. We would also like to thank our editor, John Elkins, for his detailed corrections and useful comments.

Thanks also to the many industry executives, consultants and analysts with whom we have discussed this topic, but as always the results of the analysis and any errors remain entirely our responsibility. 

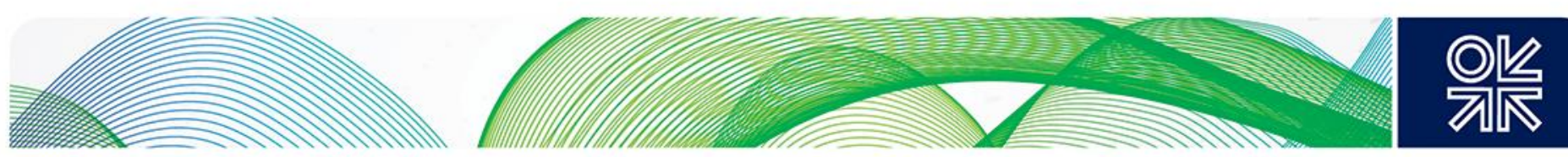

\section{Abbreviations and Units of Measurement}

$\begin{array}{ll}\text { bbls } & \text { Barrels } \\ \text { bcm } & \text { Billion cubic metres } \\ \text { bcma } & \text { Billion cubic metres per annum } \\ \text { bn bbls } & \text { Billion barrels } \\ \text { boepd } & \text { Barrels of oil equivalent per day } \\ \text { bpd } & \text { Barrels per day } \\ \text { FSU } & \text { Former Soviet Union } \\ \text { IOC } & \text { International Oil Company } \\ \text { kboepd } & \text { Thousands of barrels of oil equivalent per day } \\ \mathrm{kbpd} & \text { Thousands of barrels per day } \\ \mathrm{km} & \text { Kilometres } \\ \mathrm{mm} \text { bbls } & \text { Million barrels } \\ \mathrm{mcm} & \text { Thousands of cubic metres } \\ \mathrm{mmboepd} & \text { Millions of barrels of oil equivalent per day] } \\ \mathrm{mmbpd} & \text { Millions of barrels per day } \\ \mathrm{mmbtu} & \text { Million British thermal units } \\ \mathrm{mmcm} & \text { Millions of cubic metres } \\ \mathrm{mt} & \text { Millions of tonnes } \\ \mathrm{mtpa} & \text { Millions of tonnes per annum } \\ \mathrm{Mm} \text { tonnes } & \text { Millions of tonnes } \\ \mathrm{P} \& \mathrm{P} & \text { Proved and Probable } \\ \mathrm{tcm} & \text { Trillion cubic metres }\end{array}$

\section{Conversion Factors}

\begin{tabular}{|clcl|}
\hline \multicolumn{3}{c|}{ Equals } \\
\hline 1 & tonne oil & 7.3 & barrels of oil equivalent \\
1 & tonne condensate & 8.0 & barrels of oil equivalent \\
& & & \\
1 & bcm gas & 6.6 & mm barrels of oil equivalent \\
1 & bcm gas & 35.3 & billion cubic feet of gas \\
1 & bcm gas & 0.9 & mm tonnes of oil equivalent \\
\hline
\end{tabular}

Source: BP Statistical Review 

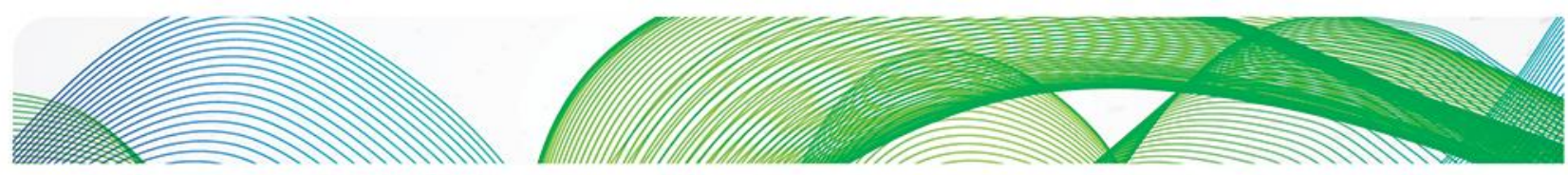
O는

\section{Contents}

Preface

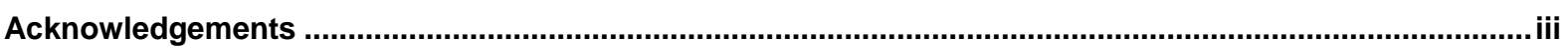

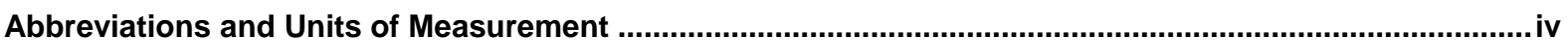

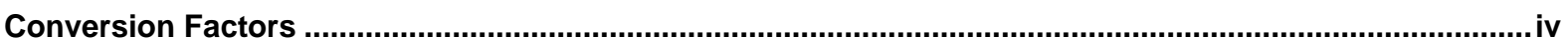

Introduction .................................................................................................................................................. vi

1. New environment for the Russian gas export strategy: Gazprom has an excess of gas looking for a market, and is also under political pressure in its western markets ................................................................

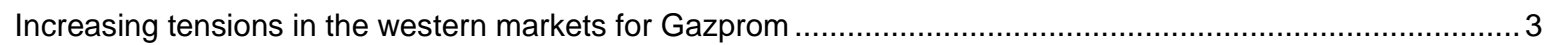

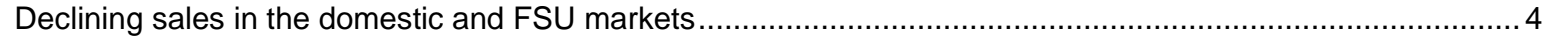

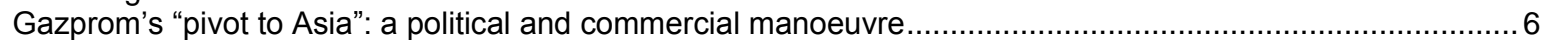

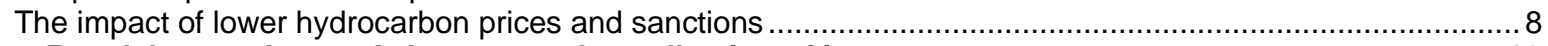

2. Russia's gas pivot to Asia - a complex collection of issues .................................................................10

China's complex gas supply and demand issues lead to uncertainty over import needs............................... 10

Russia's position in the Chinese gas supply compass...................................................................... 14

Russia and China have been negotiating for a long time, in particular about price.................................... 17

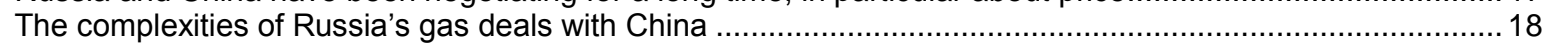

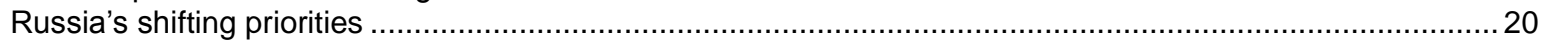

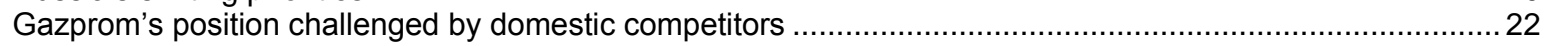

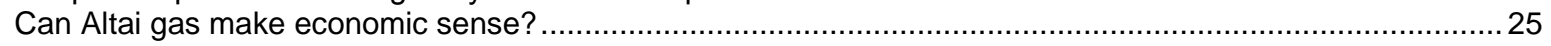

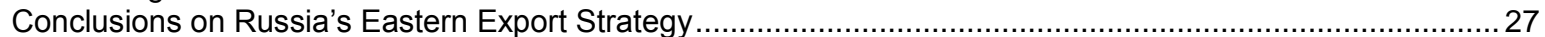

3. New strategy for Russian gas in the European market: "under construction" ......................................29

Soviet and Russian gas in the European market: historical overview .......................................................29

Economic crisis of 2008/09 catalysed significant changes in the functioning of the European gas market ......31

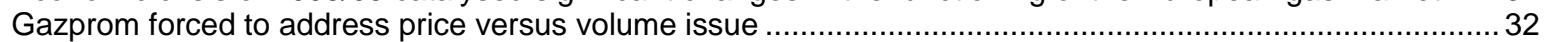

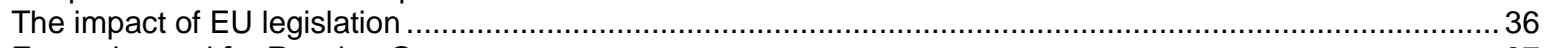

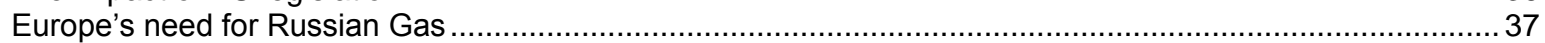

Gazprom's long-term contracts underpin confidence in European future ................................................4 41

How might Gazprom and Russia react to commercial and legislative pressure? Is a compromise solution

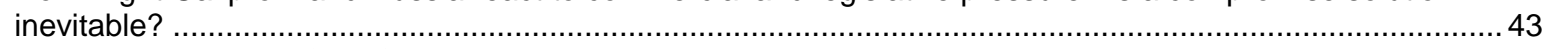

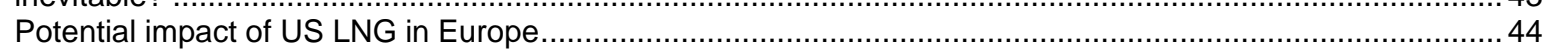

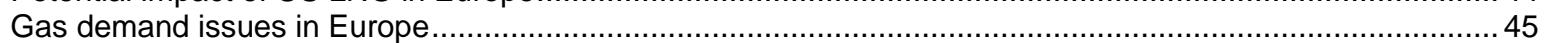

Corporate structure of European gas sector and Gazprom's long-term contracts .....................................46

Impact of European Commission regulations and investigations .......................................................... 48

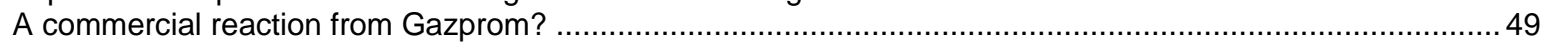

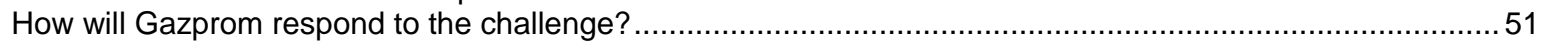

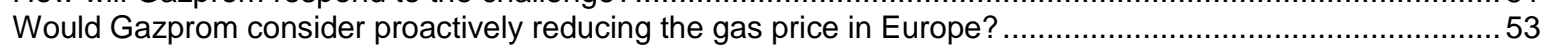

A preference for the status quo, but preparation for competition ........................................................5 55

Combination of evolving commercial strategy and complex political situation in Ukraine is reflected in volatile

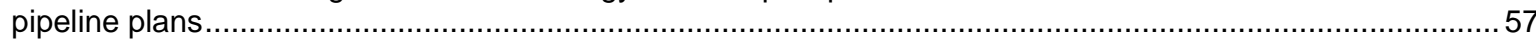

Russia's export pipeline strategy demonstrates the evolving nature of Gazprom's European plans ..............60 60

Given the uncertainty, what are the realistic options for Gazprom's export pipelines? .................................6 62

Russia's LNG strategy is also in a state of flux, with Novatek set to replace Gazprom as the country's leading

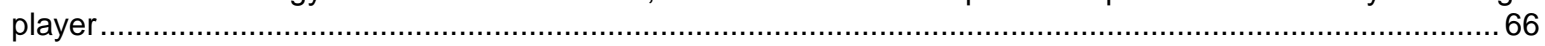

Is it possible that Gazprom's pipeline export monopoly could be broken? .......................................... 74

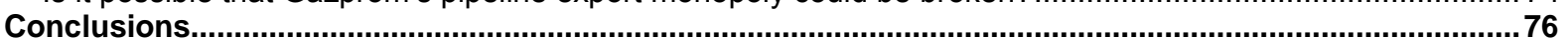

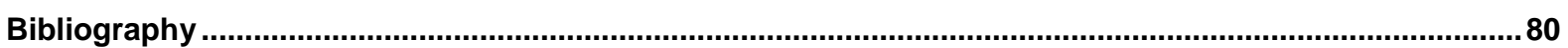

\section{Figures}

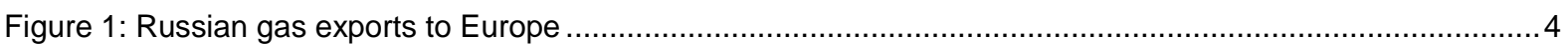

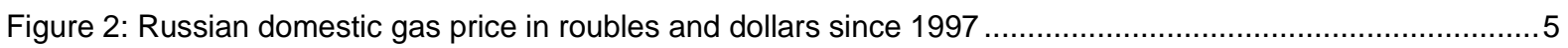

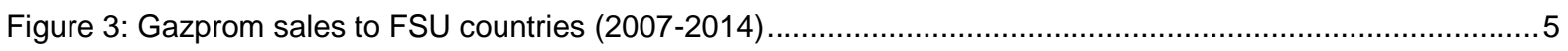

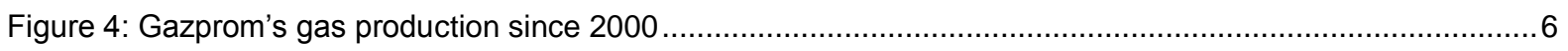



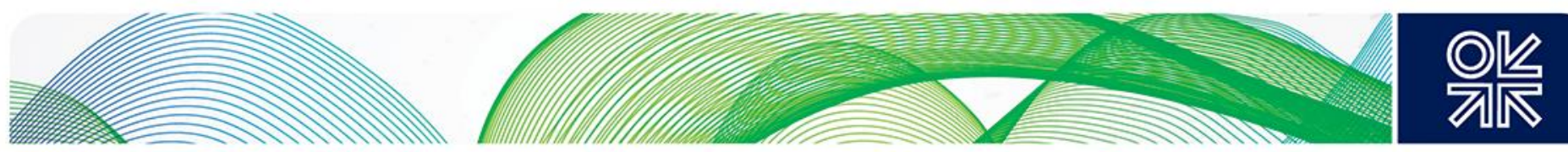

Figure 5: Split of Russia's Eastern Gas Reserves.

Figure 6: Actual and estimated Gazprom revenues and EBITDA ............................................................ 8

Figure 7: Range of potential Chinese gas supply and demand estimates................................................. 12

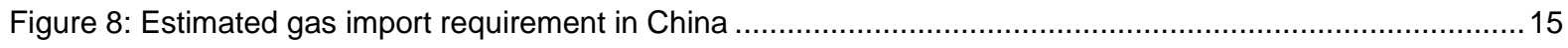

Figure 9: Potential sources of gas imports to China (excluding Non-Russian LNG) ..................................... 15

Figure 10: Estimated Russian share of Chinese gas imports under three scenarios ......................................16

Figure 11: Estimated residual demand for LNG under three scenarios........................................................16

Figure 12: Potential impact of new Asian contracts on Russian gas exports in a worst case scenario in Europe.19

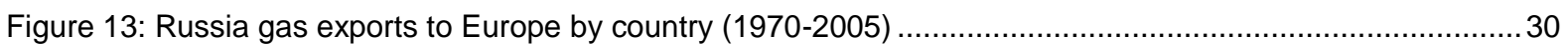

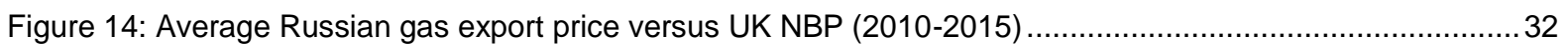

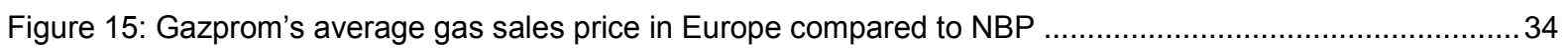

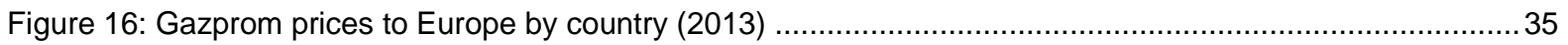

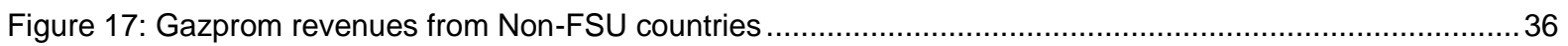

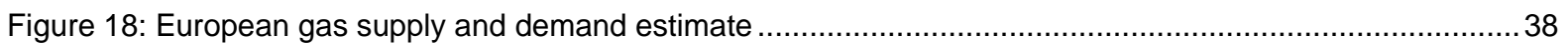

Figure 19: Volume of Gazprom's long-term contracts (LTCs) to Europe...................................................41

Figure 20: A range of possible outcomes for Russian gas exports to Europe .............................................43

Figure 21: The cost of US LNG versus European gas prices.............................................................4

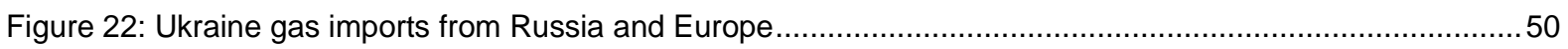

Figure 23: Competitive position of Russian gas in Europe ......................................................................52

Figure 24: Gazprom current and proposed pipeline capacity to Europe .....................................................61

Figure 25: Theoretical cost of supply from Baltic LNG project compared with US LNG ..................................... 72

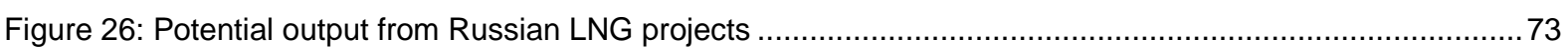

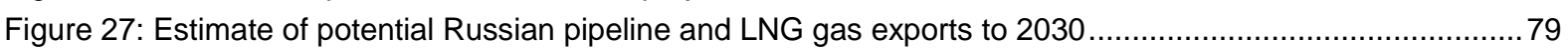

\section{Tables}

Table 1: Russian companies in the energy sector affected by US and EU sanctions

Table 2: Benchmark of Chinese Gas Import Prices for Potential Altai Gas Supply (Netbacks to Russia/China Border)

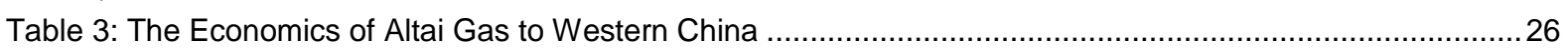

Table 4: Estimating Europe's gas import requirement to $2030(\mathrm{bcm})$ and potential sources of gas supplies.........39

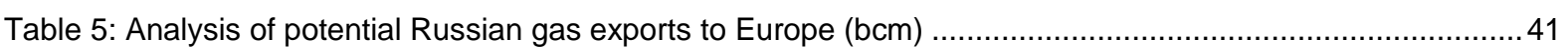

Table 6: Russian exports assuming expiry of long-term contracts at ACQ and 70\% ToP $(\mathrm{bcm}) \ldots \ldots \ldots \ldots \ldots \ldots \ldots . . . . . . . . . . . . .42$

Table 7: Comparison of scenarios for Russian export pipeline expansion to Europe .........................................66

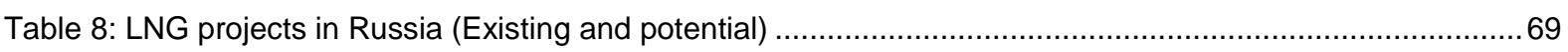

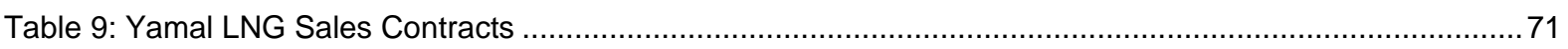

\section{Maps}

Map 1: Russia's Eastern Gas Programme, including Pipeline and LNG developments ...................................23

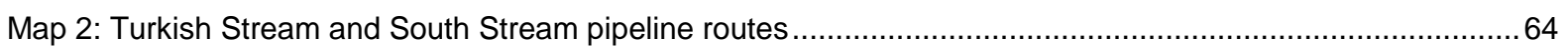

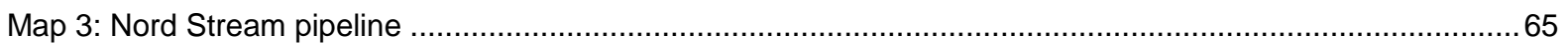



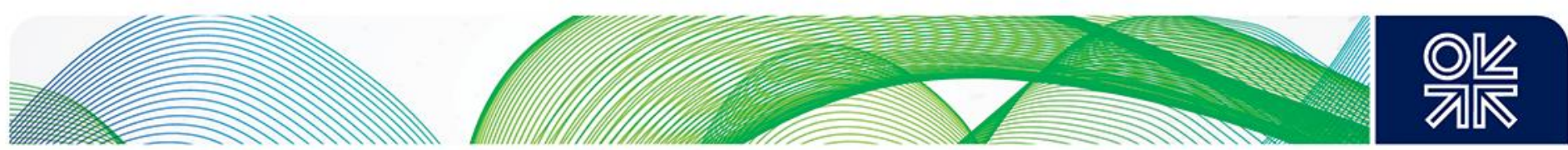

\section{Introduction}

Gas exports to Europe have been the foundation of the revenue-base of the Russian gas industry since the 1970s and have played a large part in allowing Gazprom, and its predecessor the Russian Gas Ministry, to generate the funds that could provide subsidised gas to the Russian economy. Furthermore, Gazprom has also been used for political purposes, with varying degrees of success, domestically, in the FSU and in Europe, with the Russian government using its majority ownership of the company, as well as its implicit control over gas revenues, as a foreign and domestic policy tool. However, attempts to juggle commercial logic with political objectives are bound to involve complex trade-offs given the uncertain nature of both. In the early to mid-2000s Russia and Gazprom appeared set to become ever more important players in a growing European gas market, with pressure being applied by consumers to ensure that adequate Russian production and transport infrastructure would be available. ${ }^{1}$ In contrast, by 2014 the impact of the US shale revolution, economic stagnation in Europe since 2008, increased energy efficiency, the rise of renewable energy, the arrival of cheap coal and the impact of the geo-political crisis in Ukraine have all served to undermine that view. As a result, Russia now faces the prospect of its major customers in Europe reducing their gas demand while at the same time seeking to diversify away from Russian supply. Furthermore, Gazprom's largest export market in the FSU, Ukraine, is also reducing its purchases of Russian gas, while the transit corridor that has been the backbone of Russian gas exports to Europe has become a continuous cause of uncertainty and debate.

The combination of all these factors, and in particular the strong sense that Europe would prefer to reduce purchases of Russian gas if possible, has led to a re-assessment of Gazprom and Russia's gas export strategy and also to an element of improvisation as the search continues for options to solve both short and long term issues. The opening of a new export route to Asia, plans for an expanded LNG business and a re-focussing of Gazprom's European export strategy are three of the key themes, and this paper will attempt to analyse both the political and commercial consequences for Russia and Gazprom and also for implications for the global gas market. In Part 1 we consider Gazprom's position in its traditional export markets, where it is under pressure to find customers for its gas at a time when it appears to have a significant excess of supply capacity. We conclude that the logic for a "pivot to Asia" has been apparent for some time, but that it has taken a political catalyst to accelerate the move east. In Part 2 we consider Russia's gas export plans in Asia, first highlighting the complexity of the Chinese gas supply and demand balance before considering the country's compass-like import strategy, which certainly can have room for some Russian gas from the north. We then discuss the gap for Russian gas in China, and consider the long-running negotiations between the two countries over export sales, which have generally found price to be the main sticking point. Next we consider the two deals that have been signed, for exports in the east via the Power of Siberia pipeline and in the west via the Altai (now Power of Siberia-2) pipeline, and discuss the conflicting interests of China and Russia concerning route priority. We then consider how Gazprom's position in the export market is being challenged by Novatek and Rosneft but also show how all of Russia's eastern LNG plans have been delayed. Indeed Gazprom has expressed a preference for developing the Altai pipeline over its original plans for Vladivostok LNG, and we consider the logic of this decision and the viability of the western pipeline route in the next part of the analysis, before presenting conclusions on Russia's eastern export strategy which suggest that it may not be quite the short-to-medium term insurance policy which the Kremlin and Gazprom had hoped for.

In Part 3 we then turn back to Gazprom's export strategy in Europe, first outlining the history of gas supply dating back to the late 1960s before outlining how the economic crisis of 2008/09 catalysed major changes in the market. As a result of this and other major factors, such as the advent of US

${ }^{1}$ For example see Stern (2009a) 

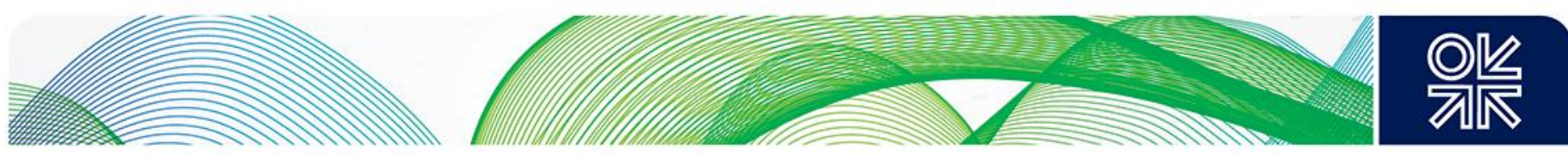

shale gas and European renewables, Gazprom has been forced to address the question of whether to maximise price or volume, and we discuss how the company's pricing strategy has evolved in the period 2008-2014 as it has been forced to adapt to changing market conditions. In the next section we consider the impact of EU legislation on the company's activities in Europe, in particular focussing on Russia's gas export pipeline plans, which reflect the evolving nature of the country's export strategy overall. Having assessed the large amount of pipeline capacity that Gazprom is considering for construction we then look at Europe's need for Russian gas in light of the continent's widening gap between demand and supply and also considering its import alternatives, including pipeline gas and LNG. We then assess how Gazprom might respond to commercial and political pressure over the coming years, and ask the question whether the company might be tempted to bring the European gas price sharply lower in order to disincentivise competition for its gas. We suggest that there may be a number of reasons why it may be tempted to do this, although it clearly would not be a strategy without significant risk. We then attempt to link Gazprom's strategy in Europe with its plans in Asia and also Russia's overall plans for expanding its presence in the LNG business in the Atlantic and Pacific Basins, considering whether this more global outlook may also encourage a new marketing strategy in Europe. We also consider whether the ending of Gazprom's monopoly on LNG exports might be extended to pipeline sales, before presenting our overall conclusions on Russia's gas export strategy. 

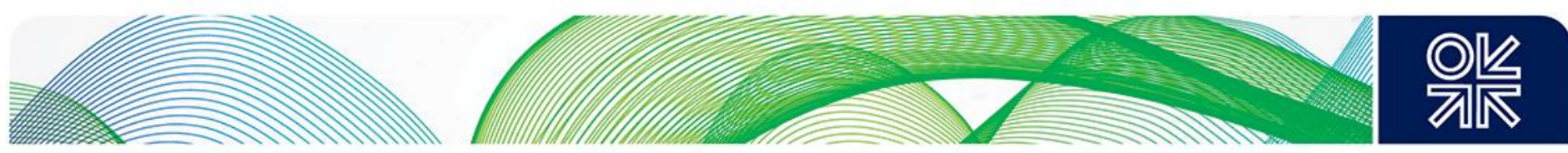

\section{New environment for the Russian gas export strategy: Gazprom has an excess of gas looking for a market, and is also under political pressure in its western markets}

\section{Increasing tensions in the western markets for Gazprom}

From a purely commercial perspective, Gazprom needs to find new markets for its developed gas reserves. As mentioned above, in Europe it has been surprised by changes in the marketplace since 2008 which have both reduced overall gas demand and led to a growing perception that customers are searching for alternatives to Russian gas where possible. Overall European gas consumption fell from $577 \mathrm{bcm}$ in 2008 to $528 \mathrm{bcm}$ in 2013 and below $500 \mathrm{bcm}$ in $2014,{ }^{2}$ with the outlook remaining relatively bleak as most forecasters do not see demand recovering to 2008 levels before the mid2020s at the earliest. ${ }^{3}$ Although from a Russian export perspective this decline has been offset by problems with North African gas exports and by the diversion of LNG to Asia following the Fukushima disaster, nevertheless Gazprom's sales to Europe have been relatively stagnant, and indeed declined sharply in 2014 (see Figure 1).

Furthermore Russia's geo-political problems in Ukraine have also undermined European confidence in Russia as a secure source of gas supply. The interruptions in transit through Ukraine in 2006 and 2009 raised questions about the need for the EU to reduce its perceived dependence on Russian gas, and these concerns have been amplified since the annexation of Crimea in February 2014 and the subsequent conflict in East Ukraine. Russia has argued that the Ukraine transit risk can be solved by construction of bypassing transit pipelines, and it has offered several alternatives including South Stream, Turkish Stream and an expansion of Nord Stream. However, the EU has responded rather differently, introducing legislation such as the Third Energy Package to liberalise the gas market and to make it more difficult for major producers such as Gazprom to dominate by controlling infrastructure or by monopolising individual markets. ${ }^{4}$

The EU has also started proceedings against Gazprom, via its competition authority DG COMP, alleging unfair practices and pricing, and although we will discuss the detailed implications of these moves in Part 3, it is enough to say here that the regulatory drive to ensure that Gazprom, as well as the other major gas market participants, adhere to new EU rules, has added to the pressure which Gazprom was already feeling due to the commercial issues mentioned above.

Meanwhile the threat of new sources of supply has started to emerge, the most notable example being the planned arrival of $10 \mathrm{bcma}$ of Azeri gas via the TANAP and TAP pipelines from the end of this decade, while the continuing growth of shale gas production in the US has provided increasing hope of LNG imports arriving at Henry Hub-linked prices from 2016. ${ }^{5}$ Furthermore, this US LNG, which is being portrayed in some quarters as a potential "saviour" of the European market, ${ }^{6}$ is likely to be supplemented over the next five years by LNG from sources such as Australia and Papua New Guinea, which will be entering the international gas market and creating a potential global oversupply situation. ${ }^{7}$

\footnotetext{
2 Total for EU35 provided by Eurostat

For example Honore, A. (2014), p.64, IEA (2014), p.139

${ }^{4}$ Stern, Pirani and Yafimava (2015) pp.3-5

${ }^{5}$ For detail see Stern et al. (2014c)

${ }^{6}$ Washington Post, 7 Mar 2014, "Can US natural gas rescue Ukraine from Russia?"

7 Fitch Ratings, 7 May 2015, "Oversupply, price risks dimming US LNG prospects
} 

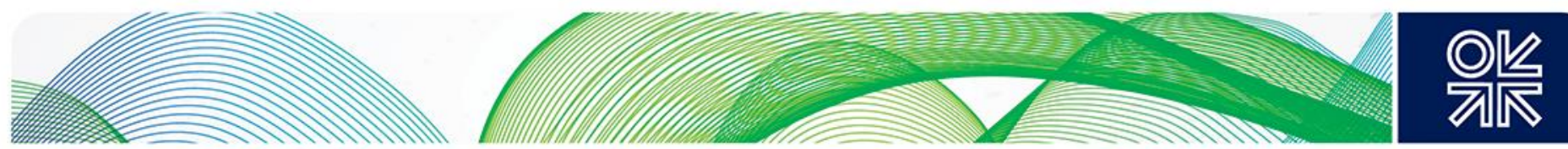

Figure 1: Russian gas exports to Europe

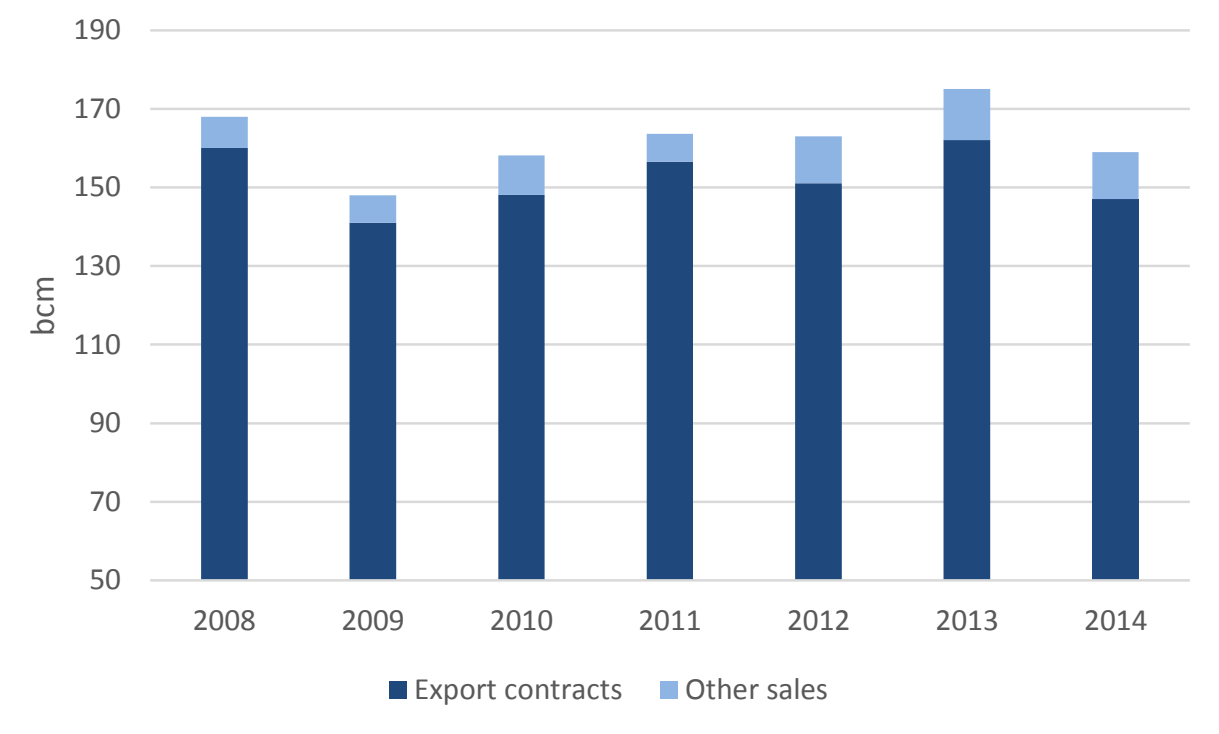

Source: Gazprom Strategy Day Presentation to Investors, 2014 slide 29 and 2013 slide 25

\section{Declining sales in the domestic and FSU markets}

Pressure on Gazprom sales to Europe has been exacerbated over the past 5 years by declines in the company's sales to its two other major markets, Russia and the FSU. Gazprom has lost significant volumes in its core domestic market over the past decade due to two main factors. Firstly, Russian gas demand has been relatively stagnant as the country's economic growth has remained slow following the 2008/09 crisis, with the 2014 fall of $1.4 \%$ to $453 \mathrm{bcm}$ marking a third consecutive year of decline and meaning that consumption is now $10 \mathrm{bcm}$ below the 2008 figure. ${ }^{8}$ Secondly, Gazprom has faced increasing competition from independent gas producers, especially Novatek and Rosneft, who have taken advantage of a rising regulated gas price (at least in rouble terms) to offer discounts to Russian industrial and power generation companies in order to win market share from Gazprom, which must by law sell its gas at the regulated price with no discount. ${ }^{9}$ As a result, Gazprom has lost almost 90bcma of gas sales in its domestic market between 2006 and 2013, compounding the issues it has faced in its major export markets.

Moreover, rouble devaluation at the end of 2014 and in the first half of 2015 has reduced domestic gas prices in US dollar terms down towards a level last seen in 2008, thus further decreasing Gazprom`s profitability and implying further subsidization of the domestic market from the export revenues.

\footnotetext{
${ }^{8}$ Gazprom Presentation, 29 April 2015, "2014 IFRS Consolidated Financial Results", slide 16

${ }^{9}$ Henderson (2015), p.363
} 

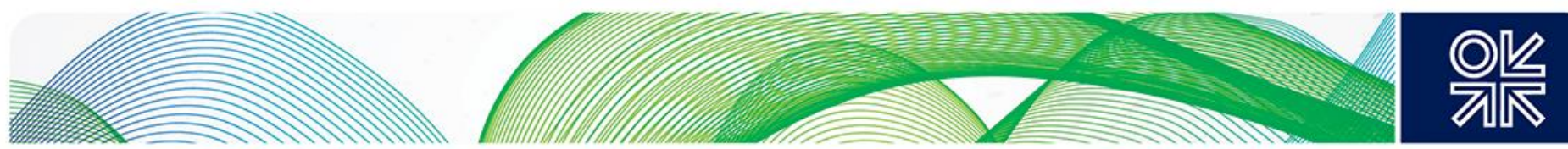

Figure 2: Russian domestic gas price in roubles and dollars since 1997

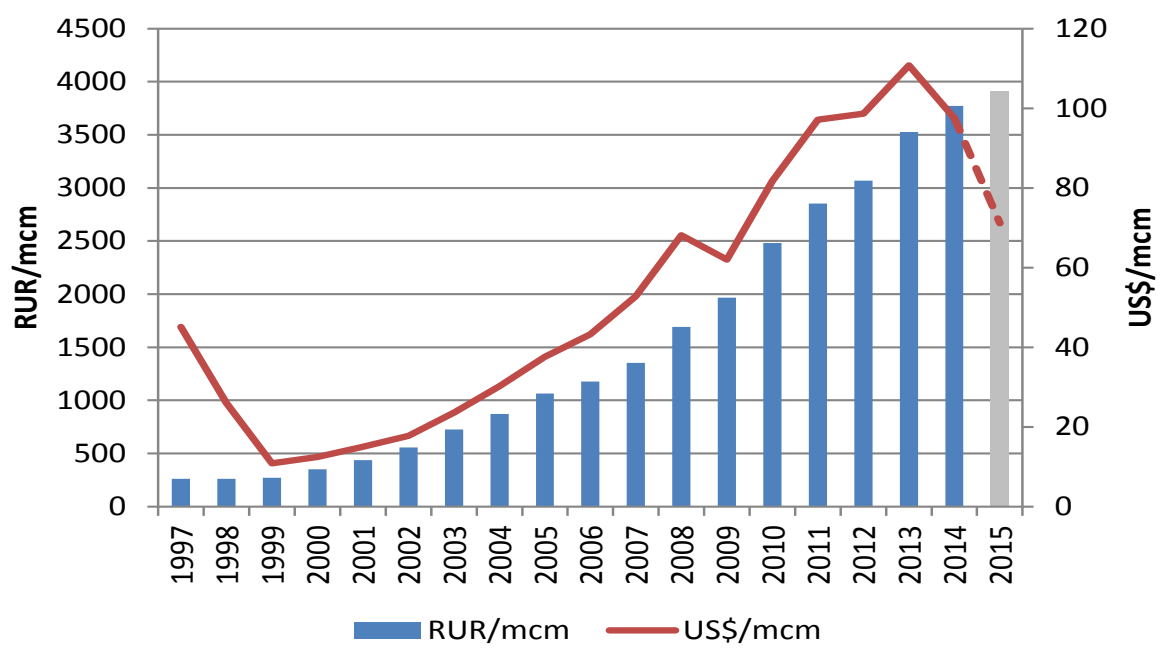

Source: Federal Tariff Service of the Russian Federation

Gazprom's gas sales issues have been magnified further by the fall in exports to FSU countries, led by Ukraine's decision to reduce its demand for Russian gas initially due to rising prices and then because of the conflict in Eastern Ukraine, which it regards as being catalysed by Russia. As a result, its imports of Russian gas have fallen from almost $60 \mathrm{bcm}$ in 2007 to less than $15 \mathrm{bcm}$ in 2014 (see Figure 3). Although sales to Russia's other major FSU customer, Belarus, have remained flat thanks to a preferential pricing policy for members of the Eurasian Economic Union, nevertheless overall exports to FSU countries have more than halved since the 2008 economic crisis, while revenues have fallen by $21 \%$ over the same period in dollar terms, reflecting the average increase in prices. ${ }^{10}$

Figure 3: Gazprom sales to FSU countries (2007-2014)

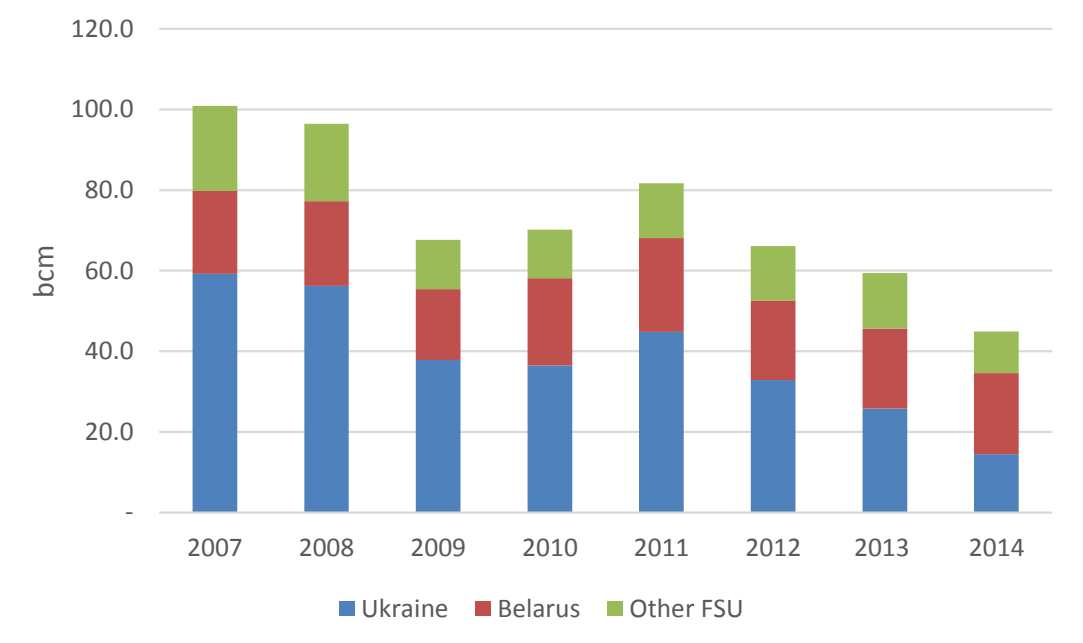

Source: Gazprom Databook 2009-2013, Interfax

${ }^{10}$ Gazprom Management Discussion and Analysis for 2008 and 2014 shows that in 2008 96.5bcm of gas was sold to the FSU at an average price of $\$ 159 / \mathrm{mcm}$. By 2014 the volume had fallen to $48.1 \mathrm{bcm}$ while the price had risen to $\$ 262 / \mathrm{mcm}$. When the volumes for the Baltic States are removed (Gazprom continues to include them in its FSU data) this implies a decline in revenues from $\$ 14.7 \mathrm{bn}$ in 2008 to $\$ 11.6 \mathrm{bn}$ in 2014. 

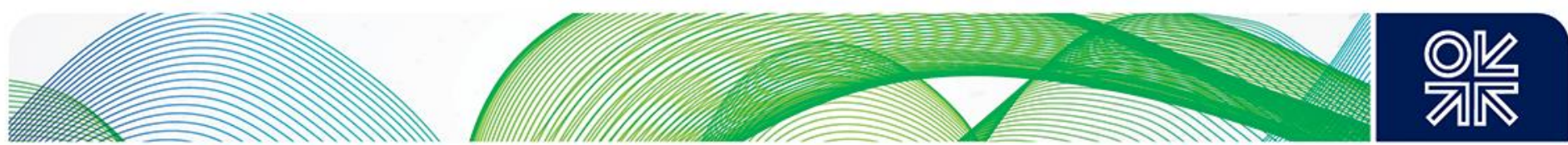

To make matters worse for Gazprom, these demand problems have come at a time when the company's supply capacity has been increasing due to the decision, taken in the mid-2000s when it appeared that gas demand growth would be much more robust, to begin development of the giant gas fields on the Yamal peninsula in northern West Siberia. ${ }^{11}$ The first field to be developed, Bovanekovo, has reserves estimated by Gazprom at $4.9 \mathrm{tcm},{ }^{12}$ with a production capacity of up to $140 \mathrm{bcma}$ if all its reservoirs are exploited fully. However, the lack of demand for Gazprom's gas has meant that at present the field is only producing around $43 \mathrm{bcma}$ and plans for increasing output have been delayed by a number of years. ${ }^{13}$ Indeed Gazprom's overall production has fallen consistently since 2008, because the company has been forced to rein in output due to a lack of demand for its gas. From a high of $550 \mathrm{bcm}$ in 2008 production has declined by more than $100 \mathrm{bcm}$ to $445 \mathrm{bcm}$ in 2014, and after a further 13\% fall in the first half of 2015 the Russian Economic Development Ministry has suggested that output for the full year may be as low as $414 \mathrm{bcm}$ (see Figure 4 below).

Figure 4: Gazprom's gas production since 2000

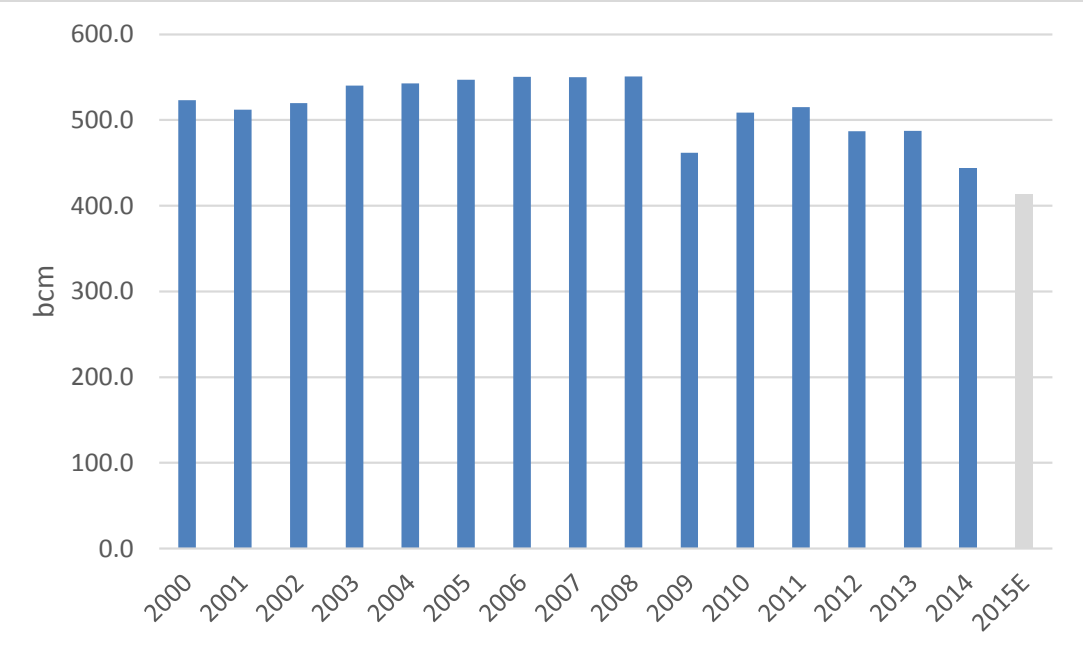

Source: Gazprom

As a result, the premature development of the Yamal fields combined with the continuing availability of production from Gazprom's core assets means that the company currently has a production capacity of more than $600 \mathrm{bcma}$, according to the company's CEO Alexei Miller. ${ }^{14}$ Even if this is a slight exaggeration, based on peak daily capacity rather than an annual average, the fact that the company produced almost $20 \%$ less gas in 2014 than in 2008 despite developing a giant new field demonstrates that there is an effective gas bubble in Russia, meaning that Gazprom is very eager to find new markets for its output.

\section{Gazprom's "pivot to Asia": a political and commercial manoeuvre}

As a result, the commercial logic for seeking new gas sales from the world's fastest growing gas markets in Asia has been obvious for some time, and indeed the first tentative moves in this direction were taken as early as the 1990s. ${ }^{15}$ However, the first formal co-operation agreement between Gazprom and Chinese state company CNPC was not signed until 2004, and it then took another

\footnotetext{
${ }^{11}$ Henderson \& Pirani (2014), pp.265-269

12 For a detailed description of the Bovanenkovo field see Gazprom web site at:

http://www.gazprom.com/about/production/projects/deposits/bm/

13 Interfax, 5 May 2015, "Gazprom slashes Bovanenkovo production plan nearly 50\% in 2015"

${ }^{14}$ Speech by Alexei Miller at Valdai International Discussion Club in Berlin, 13 April 2015, sourced from Gazprom web site at:

http://www.gazprom.com/press/miller-journal/029076/

${ }^{15}$ Henderson (2011b), pp.6-10
} 

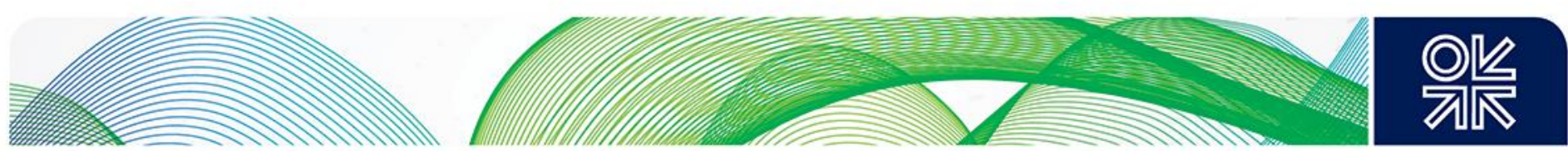

decade before a final sales and purchase agreement could be finalised in May 2014. Ironically, this initial deal for gas to be sold from East Siberia via the Power of Siberia pipeline into north-east China does not solve Gazprom's oversupply issue, as the gas will come from new East Siberian fields not from the existing "gas bubble" in West Siberia, but nevertheless it does demonstrate how the alignment of Russia's political objectives with commercial reality is vital if Russia's gas export strategy is to succeed.

Ostensibly the logic for linking Russia's huge gas reserves with China's growing gas demand is irrefutable. On the one side Russia has $31 \mathrm{tcm}$ of total proved gas reserves ${ }^{16}$ and, as has been noted above, a surplus of production capacity seeking out new markets. Furthermore, an additional $7.5 \mathrm{tcm}$ of probable reserves are located in East Siberia, much of it controlled by Gazprom in two major fields, Chayanda and Kovykta, but with significant gas also held by Rosneft and other "independent" operators (see Figure 5 below). Both Gazprom, which currently has a monopoly on pipeline exports from Russia, and the Russian government, which generates significant revenues from a $30 \%$ gas export tax and is keen to encourage regional development in the Far East of the country, ${ }^{17}$ are highly incentivised to monetise these assets from an economic perspective.

\section{Figure 5: Split of Russia's Eastern Gas Reserves}

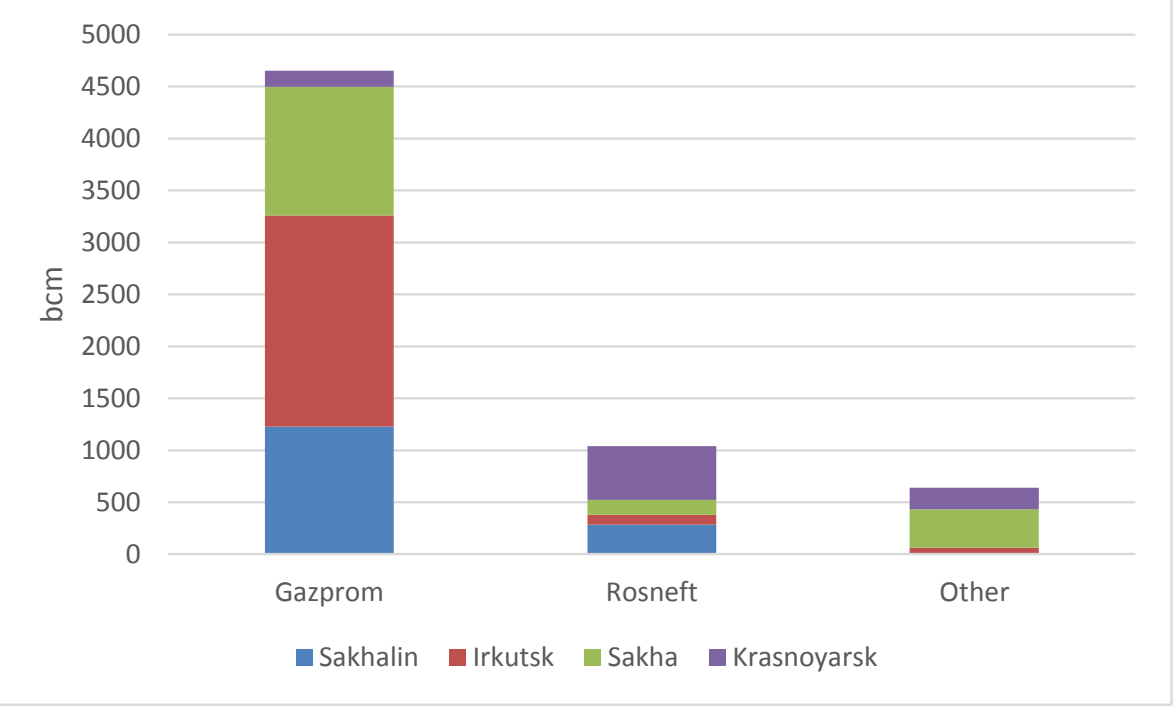

Source: Gazprom, Rosneft, Irkutsk Oil, Surgutneftegas company reports

Furthermore, a new source of exports in Asia could also provide an important commercial and geopolitical bargaining chip with traditional customers in the West and their respective governments. Although Gazprom's East Siberian fields are not connected to the main trunk pipeline system which supplies gas to western markets, the mere fact that Russia could transfer the emphasis of its export strategy towards Asia, providing a diversification away from sales to Europe, can provide a boost to its negotiating strength. Therefore, although Gazprom CEO Alexei Miller's claims that gas could be diverted to Asia if Europe obstructs Russian gas exports are something of an exaggeration, ${ }^{18}$ they do nevertheless reflect Russia's political as well as commercial objective to establish an alternative avenue for gas exports in the East. Indeed President Putin himself has expressed his desire for Russia to become a swing producer between the two continents, providing it with what he believes would be leverage in both markets. ${ }^{19}$

\footnotetext{
${ }^{16}$ BP Statistical Review of World Energy 2014, p.20. Note that Russia's own estimate of its gas reserves is higher at 47tcm

${ }^{17}$ Wall Street Journal, 4 Sept 2015, "Putin pitches for foreign investment in Russia's Far East"

${ }^{18}$ Reuters, 13 April 2015, "Russia's Gazprom warns EU over gas, Ukraine"

${ }^{19}$ Reuters, 23 May 2014, "Putin says Russia may become swing gas producers for Europe, Asia"
} 

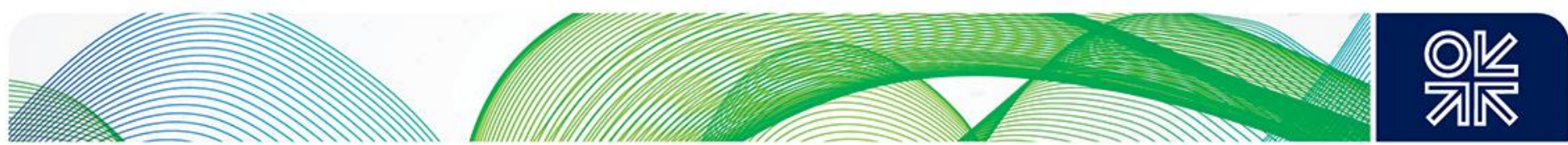

\section{The impact of lower hydrocarbon prices and sanctions}

While the commercial and political logic of this strategy is clear, the implementation of it faces significant hurdles. The specific issues of gas pricing, market dynamics and the cost of supply will be discussed below, but a more general concern for Gazprom concerns its ability to finance its export strategy in a world of lower oil (and therefore gas) prices, and at a time when sanctions imposed by the EU and the US are affecting all Russian companies. In this new environment it is becoming increasingly clear that Gazprom is very unlikely to have the ability to carry out all its investment plans, and will therefore have to make some important strategic choices either in prioritising projects or in securing partners to help it finance new developments.

The issue of lower gas prices is relatively transparent, as Gazprom's revenues from Europe and the FSU are set to fall sharply in 2015 and 2016, with the latter year a particular concern because of the 6-9 month lag effect in the setting of Gazprom's export prices to Europe. ${ }^{20}$ Figure 6 below shows the consensus forecasts from a number of financial analysts and it clearly indicates that, although the estimates have been made on a variety of price and exchange rate assumptions, the overall trend is for revenues in the period 2015-17 to be at least 30\% below the range in 2012-2014, while Gazprom's EBITDA is likely to be as much as $50 \%$ lower. This will inevitably place the company under some financial stress, even though its current levels of debt are relatively modest, and will mean that less company cashflow will be available for investment purposes.

\section{Figure 6: Actual and estimated Gazprom revenues and EBITDA}

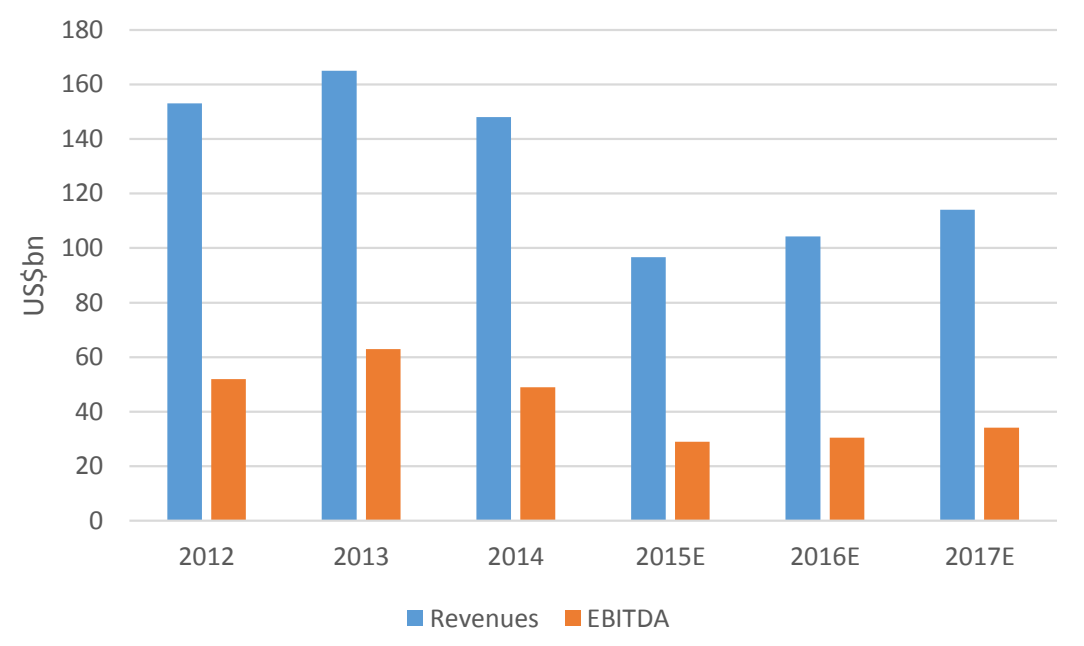

Source: Author's analysis

Under normal circumstances the company could respond to this difficult market environment by raising funds on international capital markets in anticipation of a future rebound in prices. However, the imposition of sanctions has hampered this process, even though Gazprom has not been specifically targeted from a fund-raising perspective (although one of its projects, the South Kirinskoye field in the Sakhalin 3 license, has now been put onto the sanctioned list). ${ }^{21}$ Indeed, as Table 1 shows, it is really Gazprom's two main competitors, Rosneft and Novatek, who have felt the main burden of the financial sanctions, as their ability to raise money in the US and Europe has been restricted to short-term loans ${ }^{22}$ while Rosneft's projects in the Arctic, in deep water offshore Russia and in shale oil have been banned from receiving western company assistance. ${ }^{23}$ Nevertheless, Gazprom and all Russian companies have been affected by the knock-on impact of sanctions, with

\footnotetext{
${ }^{20}$ Natural Gas Europe, 27 Oct 2014, "Gazprom relies on long-term contracts in European market"

${ }^{21}$ Reuters, 10 Aug 2015, "US sanctions put Gazprom-Shell alliance plans in jeopardy"

22 The US sanctions restrict borrowing to 30 days, the EU sanctions to 90 days

${ }^{23}$ Henderson (2015) pp.11-13
} 

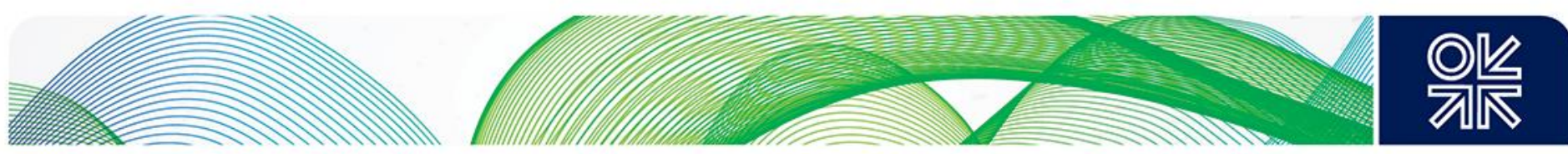

international banks and potential customers being reluctant to deal with companies which they believe might be undermined by sanctions in future. ${ }^{24}$ Furthermore, even countries such as China, which had been presumed to be a natural source of finance to replace western banks, have been reluctant to be seen to be undermining US sanctions against Russia, mindful of the fact that the US is always likely to be a more significant trading partner. ${ }^{25}$

Table 1: Russian companies in the energy sector affected by US and EU sanctions

\begin{tabular}{|l|ccccc|}
\hline & $\begin{array}{c}\text { US Treasury EO } \\
\text { 13662 Directive 2 } \\
\text { (Financing) }\end{array}$ & $\begin{array}{c}\text { US Treasury EO } \\
\text { 13662 Directive 4 } \\
\text { (Technology) }\end{array}$ & $\begin{array}{c}\text { US Commerce } \\
\text { Dept. Export } \\
\text { Controls }\end{array}$ & $\begin{array}{c}\text { EU Finance } \\
\text { Restrictions }\end{array}$ & $\begin{array}{c}\text { EU Technology } \\
\text { Restrictions }\end{array}$ \\
\hline $\begin{array}{l}\text { Transneft } \\
\text { Gazprom } \\
\text { South Kirinskoye field } \\
\text { (Sakhalin 3- Gazprom) }\end{array}$ & Yes & Yes & Yes & Yes & Yes \\
GazpromNeft & Yes & Yes & Yes & & Yes \\
Lukoil & Yes & Yes & Yes & Yes & Yes \\
Novatek & Yes & Yes & Yes & Yes & \\
Rosneft & & Yes & Yes & & \\
Surgutneftegas & & Yes & & \\
\hline
\end{tabular}

Source: US Treasury Department, US Department of Commerce, Europa.eu26

Gazprom has been particularly affected by this issue as it has tried to implement its LNG strategy, both in Asia and Europe. As will be discussed in more detail below, the company has been attempting to develop an LNG business for many years, with its only success being involvement in the Sakhalin 2 project that was originally developed by Shell. Attempts to develop the Shtokman field in the Barents Sea and the Baltic LNG project near St Petersburg both failed in the 2000s, mainly due to changing market circumstances, but more recently plans for an LNG plant at Vladivostok have been hit by a reluctance among potential customers to commit to purchasing new LNG from Russia for fear of future sanctions undermining the project. ${ }^{27}$ While other technical and operational factors have also caused a postponement in the project, the impact of sanctions on Asian LNG buyers, and consequently on banks who might have financed the project, has been significant.

The problem of raising sufficient financing is also likely to affect Russia's pipeline projects targeted at Asia and Europe, as it seems increasingly unlikely that the company will be able to persuade Asian or western banks to provide investment capital for all of them. It is therefore perhaps surprising that to date the company has appeared reluctant to accept Chinese financial assistance for the proposed export pipelines in the east, although one reason for this may be that Chinese banks have been exploiting their strong bargaining position to demand terms that have proved unattractive to Gazprom. Nevertheless, as will be discussed in the next sections, it would appear that Chinese financial, and perhaps even equity, involvement in one or more of the projects may still be necessary if they are to proceed on schedule.

\footnotetext{
24 The Moscow Times, 9 July 2014, "Sanctions push foreign lending to Russian companies to record low" ${ }^{25}$ Financial Times, 12 Oct 2014, "Chinese lenders grow wary of Russia"

${ }^{26}$ http://europa.eu/newsroom/highlights/special-coverage/eu sanctions/index en.htm, accessed on 26 March 2015

27 Financial Times, 10 Oct 2014, "Gazprom considers shelving Vladivostok LNG project"
} 

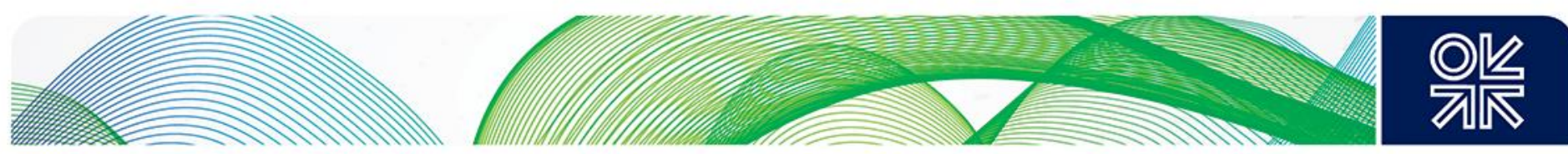

\section{Russia's gas pivot to Asia - a complex collection of issues}

\section{China's complex gas supply and demand issues lead to uncertainty over import needs}

China's gas demand has grown by a factor of almost five times in the decade from 2003-2013, with consumption growing by almost $11 \%$ in 2013 as it reached a total of over $161 \mathrm{bcm}$. This expansion has been driven by increased consumption across the Chinese economy, but in particular in the city gas and industrial sectors, although there has also been some switching away from coal in favour of gas in the power sector. ${ }^{28}$ Indeed environmental pressure continues to be a key catalyst for growth in gas demand as China seeks to reduce its reliance on coal, which accounted for $65 \%$ of total primary energy consumption in 2012 but is targeted to fall to $50 \%$ by $2030 .{ }^{29}$ In June 2014 President Xi underlined the energy revolution that this would imply for China in a speech to officials of the Communist Party, but emphasised his determination to see China diversify into non-coal energy resources, with gas, renewables and nuclear power at the forefront of this change. ${ }^{30}$

However, although the outlook for gas in the emerging Chinese energy economy looks bright, the more precise estimates for gas demand by 2020 and 2030 are less clear because of the inherent conflict between a number of issues which underpin the gas target. As outlined in detail by Paik (2015), these include:

- domestic environmental pressure which is spurring the need for a switch away from coal,

- development of China's domestic gas resources to enhance security of supply,

- balancing the sources of China's gas imports, including the split between pipeline gas and LNG, and

- the potential economic impact of switching away from cheap coal to more expensive gas. ${ }^{31}$

However, in the short term demand growth appears to be slowing, rising by only 8 to $9 \%$ in 2014 compared with a $14 \%$ average over the previous five years, ${ }^{32}$ while higher domestic gas prices also appear to be discouraging a faster pace of demand growth. ${ }^{33}$ Indeed expectations for gas demand in China by the end of the decade and beyond have been falling sharply over the past 12-18 months. For example, as recently as April 2014 some commentators continued to estimate demand in 2020 at $420 \mathrm{bcm}$, which was then reduced to $350 \mathrm{bcm}$ in data presented by CNPC and then to as low as $298 \mathrm{bcm}$ according to CNPC's Economics and Technology Research Institute (ETRI). ${ }^{34}$ External sources have also been reducing their demand estimates, with the IEA now forecasting $295 \mathrm{bcm}$ in 2020 in their latest World Energy Outlook compared to $307 \mathrm{bcm}$ in their previous projection, ${ }^{35}$ and these reductions have been given added credibility by the slow rate of demand growth in the first half of 2015 , when consumption increased by only $2.1 \% .36$

While estimates of Chinese gas demand remain unclear, the same is also true for Chinese gas production. One of the main motivations for the Chinese authorities to increase the domestic gas price has been to encourage the development of China's extensive conventional and unconventional gas resources, with a particular recent focus on shale gas, coal-bed methane and coal-to-gas as potential

\footnotetext{
${ }^{28}$ Chen (2014) p.37

${ }^{29}$ EIA, 14 May 2014, "China: International Energy Data and Analysis", p.3 sourced from

http://www.eia.gov/beta/international/analysis includes/countries long/China/china.pdf on 25 May 2015

${ }^{30}$ Cornot-Gandolphe (2014) p.12

31 Paik (2015) pp.21-22

32 IEA (2015), p.36

${ }^{33}$ O'Sullivan, S. on Trusted Sources Energy Blog, 3 March 2015, "China gas price reform to continue" sourced from http://www.trustedsources.co.uk/blogs/energy/china-to-continue-gas-price-reform on 25 May 2015

${ }^{34}$ Paik (2015) p.23

35 IEA World Energy Outlook 2014, p.139 and World Energy Outlook 2013, p.103

${ }^{36}$ Petroleum Economist, 18 June 2015, "China's natural gas demand sputters"
} 

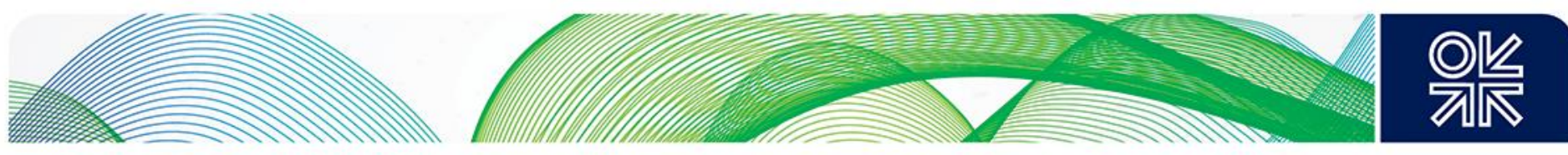

drivers of growth. Development of all these sources of gas will be important from a security of supply perspective, as China seeks to move away from an energy source in which it is almost entirely selfsufficient (coal) to one (gas) where it currently imports around $32 \%$, with this figure set to exceed $40 \%$ by 2020. ${ }^{37}$ Indeed, given that security of supply continues to be highlighted as a major issue in China's emerging energy strategy it remains unclear whether future gas demand may be constrained by the limits of China's domestic gas production, if the Chinese authorities have an implicit cap on the level of import requirement.

As a result, the future of Chinese gas production will have significant implications for all potential exporters of gas to China, but once again the range of estimates is wide. CNPC data produced in 2012 suggests that the total output from the country's three state-owned companies plus smaller local firms could reach $238 \mathrm{bcm}$ by 2020 and $311 \mathrm{bcm}$ by 2030 . On the assumption that demand reaches $300 \mathrm{bcm}$ in 2020 and $471 \mathrm{bcm}$ in $2030^{38}$, this leaves an import requirement of $62 \mathrm{bcm}$ in 2020 and $160 \mathrm{bcm}$ in 2030 . However, a more optimistic production scenario, produced by CNPC expert Xu Bo, ${ }^{39}$ suggests that output could be as high as $360-410 \mathrm{bcm}$ as early as 2020 by including some very positive estimates for unconventional gas output. Given this wide disparity in production forecasts, gas exporters such as Russia need to answer two fundamental questions as they market their gas to China. Firstly, will Chinese production meet expectations, and secondly, even if it does will this factor constrict imports or encourage higher gas demand?

One major question on the production outlook concerns unconventional gas, and in particular shale gas. Despite early positive indications, a detailed study by Gao in 2012 concluded that, despite the fact that China has potentially the largest shale gas resources in the world, ${ }^{40}$ there is unlikely to be a shale gas revolution in China by 2020 , in particular due to geological complexity, shortages of water, land access and the limitations of the service industry. This appears to have been borne out by subsequent events, as although a short term government target of $6.5 \mathrm{bcma}$ of shale output by 2015 appears achievable, medium term targets for 2020 have been halved from an initial estimate of 50 $80 \mathrm{bcma}$ to a firmer $60 \mathrm{bcma}$ and then to $30 \mathrm{bcma} .{ }^{41}$ On a more positive note Chinese gas price reform, which has seen the city-gate gas price increase to over $\$ 12 / \mathrm{mmbtu}$ in 2015 , has provided a clear boost to the shale industry and in its latest estimate the IEA remains positive over the longer term, seeing $110 \mathrm{bcm}$ of shale output in China by 2040, while CNPC and Sinopec also continue to express their confidence. ${ }^{42}$ However, the very heterogeneous nature of the shale industry and the lack of any concrete evidence for growth in China means that the ultimate outcome remains very uncertain, especially as the Chinese authorities seem reluctant to allow international companies with significant global shale experience to participate in domestic licences. As a result, this uncertainty in the shale sector adds further complexity to the country's supply/demand balance and the potential for future gas imports.

The outlooks for Coal Bed Methane (CBM) and Coal to Gas are really no clearer. To date CBM in China has been something of a disappointment, with a 2010 target of $10 \mathrm{bcm}$ of output being missed by $8.5 \mathrm{bcm} .{ }^{43} \mathrm{New}$ targets of $20 \mathrm{bcm}$ in 2015 and $40-50 \mathrm{bcm}$ in 2020 also seem unrealistic, although the EIA is forecasting growth to $28 \mathrm{bcm}$ by 2020 , implying some success in developing this new gas resource. Coal to gas technology is also being developed in order to exploit China's vast coal resources in a somewhat more environmentally friendly way, but again targets of $20 \mathrm{bcm}$ of output in 2015 rising to $60 \mathrm{bcm}$ in 2020 appear overly optimistic. Indeed it appears that the Chinese authorities

\footnotetext{
${ }^{37}$ Calculation based on data from IEA (2014), pages 139 and 149

38 The 2030 forecast is from IEA (2014), p.139

${ }^{39}$ Paik (2015), pp.23-24

${ }^{40}$ EIA/ARI (2011) World Shale Gas and Shale Oil Resource Assessment

${ }^{41}$ Reuters, 7 Aug 2014, "China finds shale gas challenging, halves 2020 output target"

42 Reuters, 30 Mar 2015, "Sinopec, PetroChina persevere with shale gas as drilling costs fall"

${ }^{43}$ O'Sullivan (2013) p.8
} 

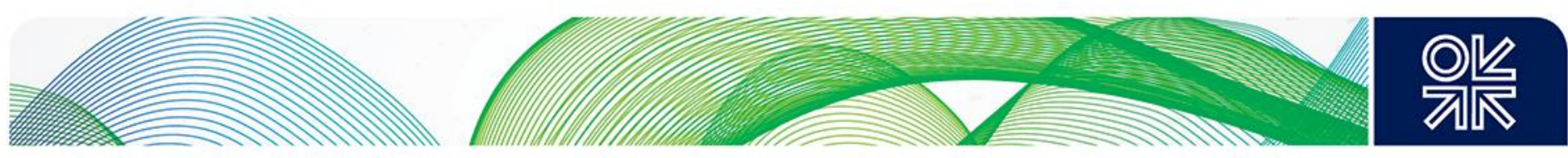

may be re-thinking their support for the industry given the environmental issues it creates (large emission of carbon dioxide in particular) and the high level of water consumption. ${ }^{44}$

As a result, the outlook for total Chinese gas production is very uncertain (see Figure 7 below). The range of realistic expectations is from a high of $238 \mathrm{bcm}$ in 2020 and $311 \mathrm{bcm}$ in 2030 from CNPC, to a mid-case of $178 \mathrm{bcm}$ and $266 \mathrm{bcm}$ from the IEA to a low case of $120 \mathrm{bcm}$ and $189 \mathrm{bcm}$ from the EIA, which would seem to assume very little unconventional gas development at all. ${ }^{45}$ Given the IEA demand forecast mentioned earlier, this implies a range of imports from $57-175 \mathrm{bcm}$ in 2020 and 160$282 \mathrm{bcm}$ in 2030, compared to imports of $58 \mathrm{bcm}$ in 2014.

\section{Figure 7: Range of potential Chinese gas supply and demand estimates}

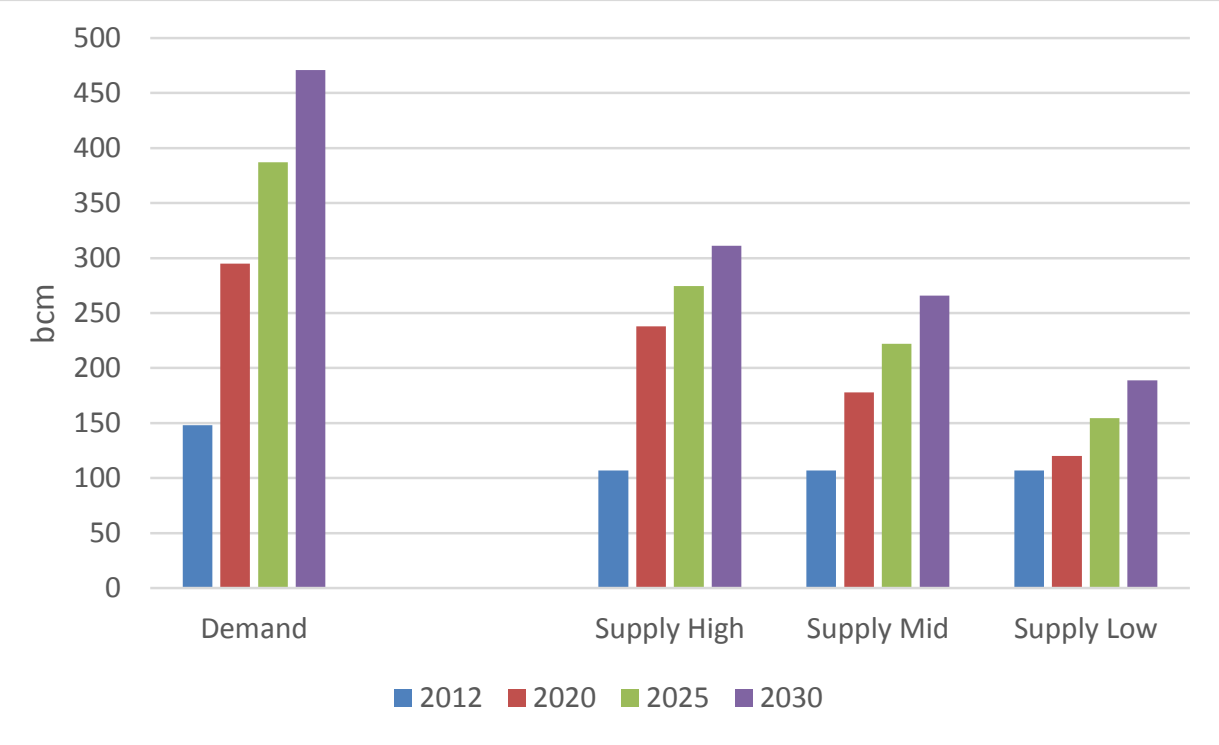

Source: IEA, CNPC, EIA data used in authors' calculations

In terms of filling this import gap, China has developed a "compass" of supply sources over the past decade to satisfy its security of supply concerns as well as its gas needs. From the west it takes gas from Central Asia, where Turkmenistan is its largest supplier. From the south gas is being supplied from Myanmar via a $12 \mathrm{bcm}$ pipeline that brings supply from the Bay of Bengal. Finally the eastern seaboard of China is also supplied by a growing number of LNG regasification facilities, bringing gas from a number of countries via a sea route, which provides further diversification from the other landbased pipeline options. The northern axis of this compass remains to be filled, and Russia is the obvious source to address this gap, with its ability to provide gas both via pipeline and LNG, the latter now being available not only from Gazprom but also soon from Novatek and perhaps Rosneft.

Strategically, then, Russian gas would appear to fit into the Chinese gas supply portfolio, but a clear question remains as to how large a volume will be required. Gas pipeline imports from Myanmar appear fixed given the capacity of the pipeline and the relatively small volumes involved, meaning that China's main currently planned source of pipeline imports is set to be Central Asia, where CNPC has invested heavily in pipeline infrastructure to bring gas from Turkmenistan, Uzbekistan and Kazakhstan via the Central Asia - China pipeline (CACP) as well as taking some upstream positions in all three countries. ${ }^{46}$ The first two lines of the CACP were completed in 2011 when full capacity of $30 \mathrm{bcma}$ became available, while Line $C$ is expected to be completed by the end of 2015 , when capacity will

\footnotetext{
${ }^{44}$ The Seattle Times, 25 Dec 2014, "China re-thinking plans to build coal-to-gas plants"

${ }^{45}$ EIA (2013)

${ }^{46}$ For a detailed description of Chinese gas investments in Central Asia see Paik (2012) pp.298-316
} 

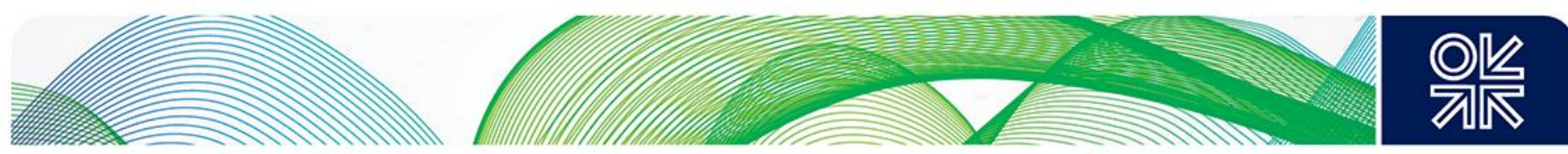

reach $55 \mathrm{bcm} .{ }^{47} \mathrm{~A}$ fourth string (Line $\mathrm{D}$ ) is also planned, which would increase capacity by a further $30 \mathrm{bcm}$ to $85 \mathrm{bcm}$ and would additionally connect China to Tajikistan and Kyrgyzstan. Contracts to fill the pipeline with gas have been signed with Turkmenistan, which is due to reach total sales of $65 \mathrm{bcma}$ by the end of this decade, Uzbekistan (10bcma) and Kazakhstan (10 bcma), although the exact timing of the deliveries remains unclear, as does whether Uzbekistan and Kazakhstan in particular have firm commitments. The nature of the deals appears to leave some room for flexibility depending on the level of Chinese gas demand and on the ability of Central Asian countries to produce enough gas. For example, Uzbekistan has a very significant domestic gas demand and may struggle to find an extra $10 \mathrm{bcma}$ for export, while Kazakhstan may also struggle to meet its full contractual commitment to Chinese gas exports. ${ }^{48}$ Indeed this uncertainty would appear to be reflected in China's decision to delay the construction of Line D of the CACP from 2016 to 2020, which suggests not only that the Chinese authorities are uncertain about their own gas demand but also that they perhaps do not want to commit completely to Central Asian gas as the only source of imports from the west. ${ }^{49}$

The other major increase in Chinese import volumes is set to come from LNG. Current regasification capacity on the east coast amounts to $32.5 \mathrm{mtpa}(44 \mathrm{bcma})$, most of which is owned by Chinese state company CNOOC, although it is increasingly being challenged by its main competitors CNPC and Sinopec and more recently by a number of private companies who now also have the right to import LNG without restriction. Indeed CNPC and Sinopec currently have 22mtpa of new capacity under construction, and the country's total capacity could rise to $80 \mathrm{mtpa}$ (109bcma) by 2018 if all the approved schemes are actually completed. ${ }^{50}$ Adding a further 13 plants that are currently at the planning stage could expand this further to $110 \mathrm{mtpa}(150 \mathrm{bcm})$ beyond 2020 . Although it is clear that actual operational throughput would be much lower than nameplate capacity, nevertheless China would seem to have the potential to import up to $100 \mathrm{bcma}$ of LNG by the early 2020 s to add to its pipeline gas imports.

The key issue for LNG imports, though, is price. China signed its first long-term LNG contract in 2003 with the North-West Shelf project in Australia at a time when the oil price was in a range of $\$ 25$ $30 /$ barrel, which resulted in a low gas price of around $\$ 3 / \mathrm{mmbtu} .{ }^{51}$ However since then the rising trend in oil prices (at least until July 2014) has meant that LNG imports have become increasingly expensive, especially when compared to the low regulated Chinese domestic gas price. As a result, although Chinese companies have signed long-term contracts that could see up to $27 \mathrm{mt}$ (37bcma) imported by 2017 and $50 \mathrm{mt}$ (68bcma) by 2030, ${ }^{52}$ supplemented of course by spot cargoes and new contracts if and when demand emerges, in reality this supply will only arrive if the price is competitive. Indeed, even at an oil price of \$65/ barrel in May 2015 it would appear that Chinese LNG importers are looking to offload cargoes, either because the price in the contract is too high or because there is insufficient gas demand in China at present. In 2014 total LNG imports amounted to $20 \mathrm{mt}(27 \mathrm{bcm})$, implying $61 \%$ capacity utilisation of the country's regasification facilities, while at the same time Chinese state companies are reported to be sellers of LNG which they have contracted over the past few years but for which they no longer have a profitable market. ${ }^{53}$ Furthermore, in the first half of 2015 imports have actually declined as demand growth stalled and indigenous production exceeded expectations, ${ }^{54}$ and as a result it would appear that China's aggressive contracting strategy, combined

\footnotetext{
47 Data from CNPC web site at http://www.cnpc.com.cn/en/FlowofnaturalgasfromCentralAsia/FlowofnaturalgasfromCentralAsia2.shtml, accessed on May 26 2015

48 Pirani (2012) p.87

49 Paik (2015) p.30

50 Ibid. pp.30-31

51 Henderson (2011b) pp.29-30

52 EIA, 14 May 2014, "China: International Energy Data and Analysis", p.30 sourced from

http://www.eia.gov/beta/international/analysis includes/countries long/China/china.pdf on 25 May 2015

${ }^{53}$ Reuters, 9 Dec 2014, "LNG boom over as China looks to sell out of long-term deals"

54 Trusted Sources Energy Blog, 3 Aug 2015, "China's gas imports decline as demand growth tumbles", sourced from http://www.trustedsources.co.uk/blogs/energy/china-s-gas-imports-decline-as-demand-growth-tumbles2 on 6 Aug 2015
} 

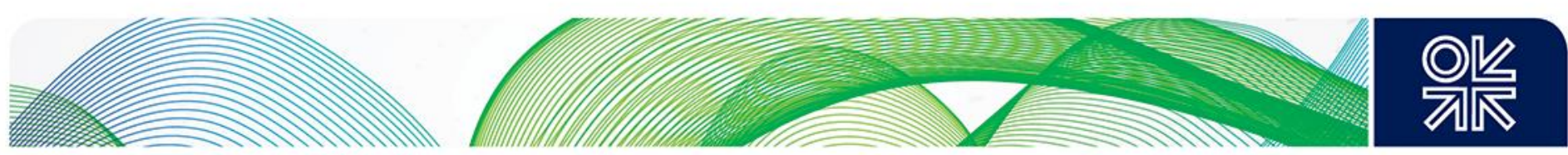

with its active investment in international LNG projects such as QCLNG in Australia, and Yamal LNG in Russia has led, at least in the short-term, to a situation of gas oversupply in China. ${ }^{55}$

\section{Russia's position in the Chinese gas supply compass}

Amid this rather uncertain picture in China, Russia has emerged as a potential exporter of up to $68 \mathrm{bcma}$ of gas (and perhaps even more in time) via pipeline plus further LNG cargoes from Yamal LNG and Sakhalin. However, despite initial contracts and memoranda of intent having been signed, significant questions remain about the outlook for Russian gas in China and NE Asia because of the demand uncertainties described above and also because of the lack of a clearly defined export strategy from Gazprom or the Kremlin. Although the overall objective for Russia is clear, to diversify its gas exports towards a growing demand region in order to expand sales and demonstrate that it has an alternative to Europe, the details of how this is going to be achieved remain under debate, and this fact alone could undermine the so-called "pivot to Asia" if it is not resolved by the end of 2016.

Perhaps the first question that needs to be asked, though, is how Russian gas might fit into the Chinese import portfolio. In answering this question a number of underlying premises need to be considered. Firstly, China clearly has security of supply concerns about all its energy sources, meaning that it will not wish to become overly reliant on one source, especially one where it has no control, such as Russia. Secondly, as it builds a gas supply portfolio China has shown a desire to balance pipeline and LNG imports, as well as prioritising indigenous production, with a notional goal of having local supply account for at least $50 \%$ of demand, and with pipeline and LNG imports accounting for the remainder in approximately equal proportions (as was the case in 2014). Finally, the level of uncertainty over future demand and supply projections means that the Chinese authorities are unlikely to want to make early commitments to an excess of inflexible pipeline options.

Bearing these points in mind it is possible to paint some scenarios of a future supply and demand balance to assess the likely realistic options for Russian gas. In doing this we have taken two forecasts of Chinese gas supply and demand, one from the IEA in Paris ${ }^{56}$ and one from the EIA in Washington, ${ }^{57}$ and calculated three gas import requirement scenarios, shown in Figure 8 . Although the EIA forecast has both lower supply and demand figures, it is interesting to note the implied import requirement is close to the IEA figure, and also to note that in both cases imports never account for more than $50 \%$ of demand. Figure 8 also includes a high case scenario, which combines the higher of the two demand estimates (IEA) with the lower supply estimates (EIA) to create a maximum import requirement. In this case imports reach a high of $62 \%$ of demand, which might be interpreted as concerning but perhaps acceptable to the Chinese authorities, given the low share of gas in the overall energy mix. ${ }^{58}$

\footnotetext{
${ }^{55}$ Arsov, Z \& Liu, L. (2012) “Natural Gas in China - potential for long-term oversupply?” Taylor Dejongh

56 IEA (2014), pp.139 and 149; EIA (2013)

${ }^{57}$ EIA (2013) tables A.1 and I.1

${ }^{58}$ In 2012 gas accounted for $4 \%$ of total primary energy demand, and is projected to account for $6 \%$ in 2020 and $9 \%$ in 2030 (IEA (2014) p.654)
} 

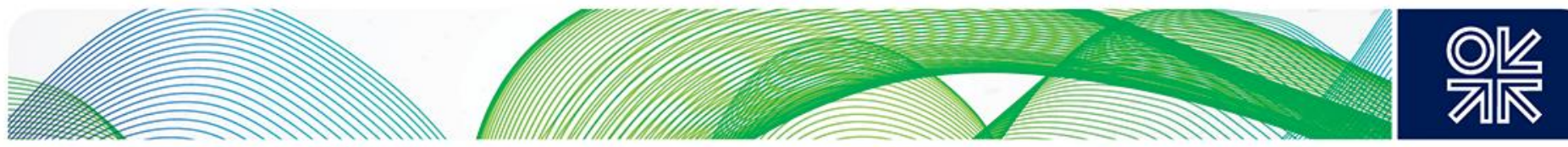

Figure 8: Estimated gas import requirement in China

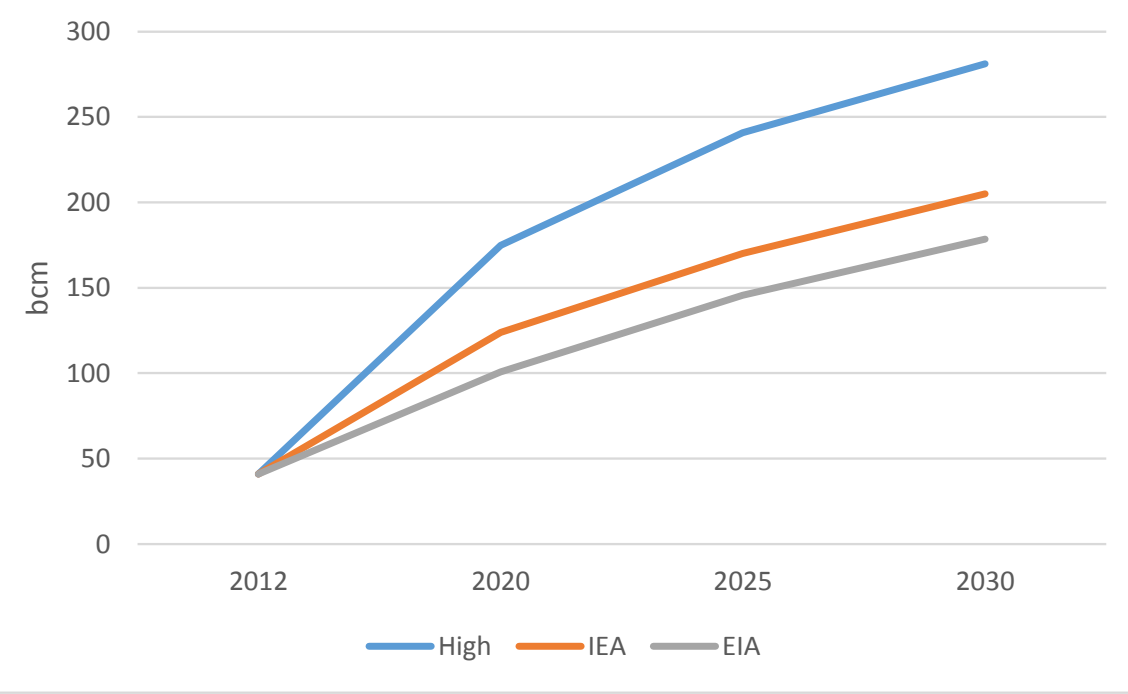

Source: Author's calculations from data in IEA (2014) and EIA (2013)

Given this range, it is then interesting to try and fit the various sources of supply into the Chinese gas import portfolio. Figure 9 shows estimates for imports from Central Asia, Myanmar and from Yamal LNG (where CNPC has a $20 \%$ interest and has contracted to buy $3 \mathrm{mtpa}$ of LNG, and where China's Silk Road Fund has recently purchased a $9.9 \%$ interest). ${ }^{59}$ It also shows the proposed Russian pipeline imports assuming that the Power of Siberia pipeline comes on line at its currently planned start-up date of 2019 (although there is the possibility of a 2-year delay to 2021) while the Altai route starts in the early 2020s. On this basis, LNG (some of which has already been contracted) would be the balancing item to fill any further gap to the overall import requirement (the three scenarios are shown in dotted lines).

Figure 9: Potential sources of gas imports to China (excluding Non-Russian LNG)

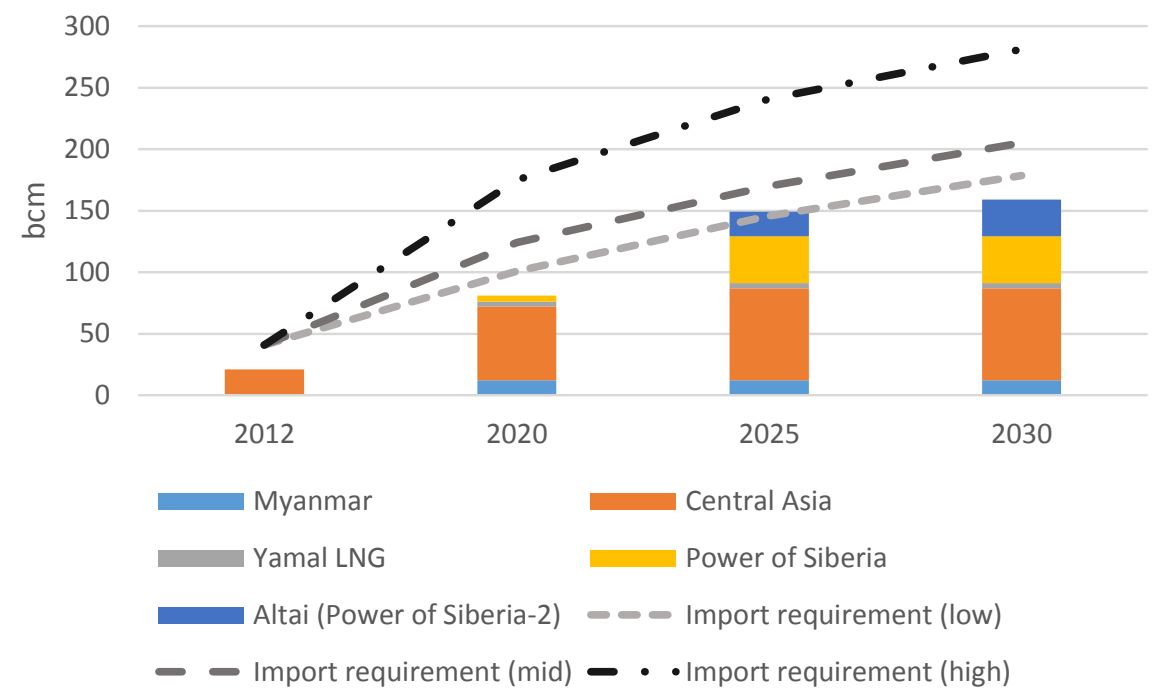

Source: Authors' estimates

${ }^{59}$ Interfax, 3 Sept 2015, "Novatek, China's Silk Road Fund sign agreement on purchase of 9.9\% stake in Yamal LNG" 

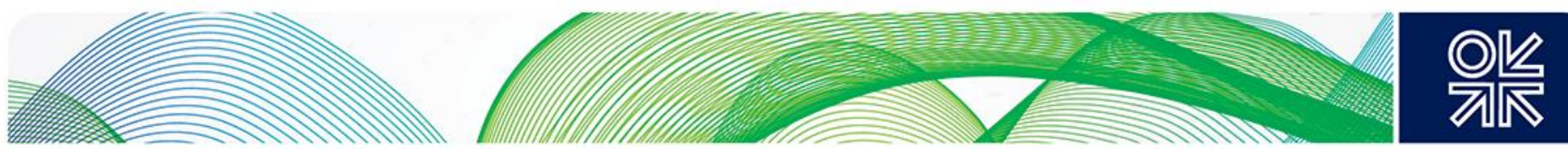

It is assumed that gas from Myanmar and Central Asia (primarily Turkmenistan, but also Kazakhstan and Uzbekistan) would be relatively secure, given China's political and commercial interests in these countries, although we have assumed that only half the 20bcma contracted from Uzbekistan and Kazakhstan will actually be delivered given the uncertainties discussed above. In addition we have also assumed that the volumes from Yamal LNG would also be secured by CNPC's equity interest. It is therefore interesting to see what impact $68 \mathrm{bcma}$ of Russian pipeline imports could have if Power of Siberia and Altai both proceed, and what role LNG would be left to play as a result. Figure 10 below shows the Russian share of Chinese gas imports if the Power of Siberia and Altai projects go ahead as shown above, while Figure 11 shows the incremental import demand for LNG other than that from Yamal.

Figure 10: Estimated Russian share of Chinese gas imports under three scenarios

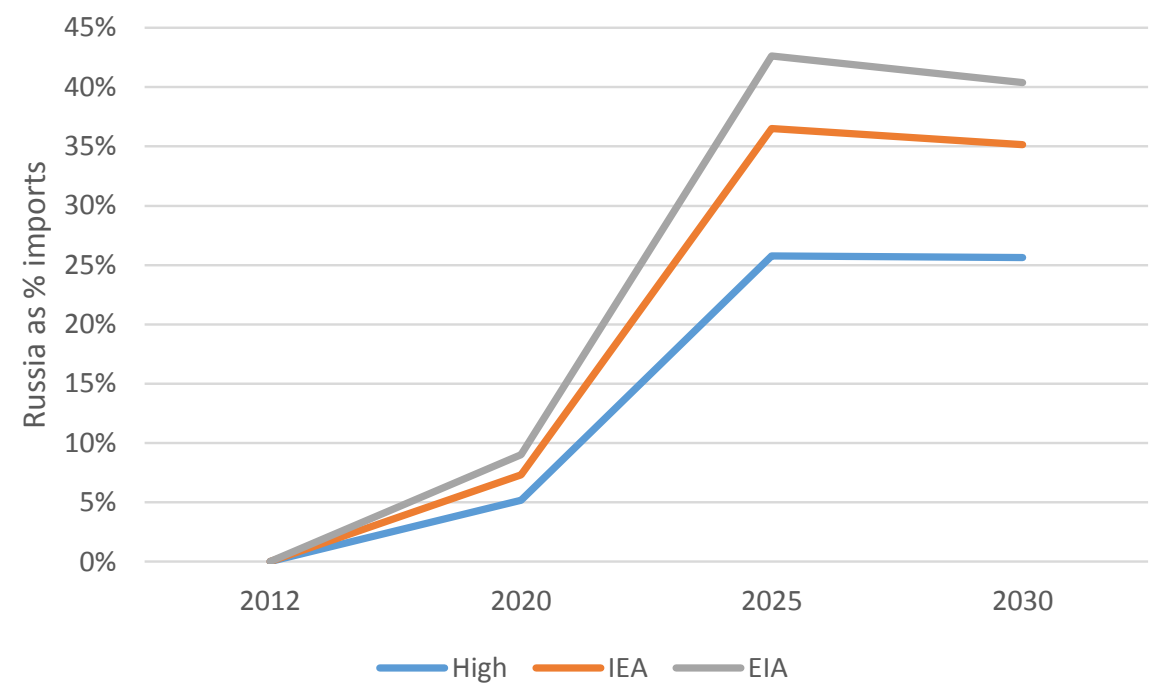

Source: Author's calculations based on assumptions outlined above

Figure 11: Estimated residual demand for LNG under three scenarios

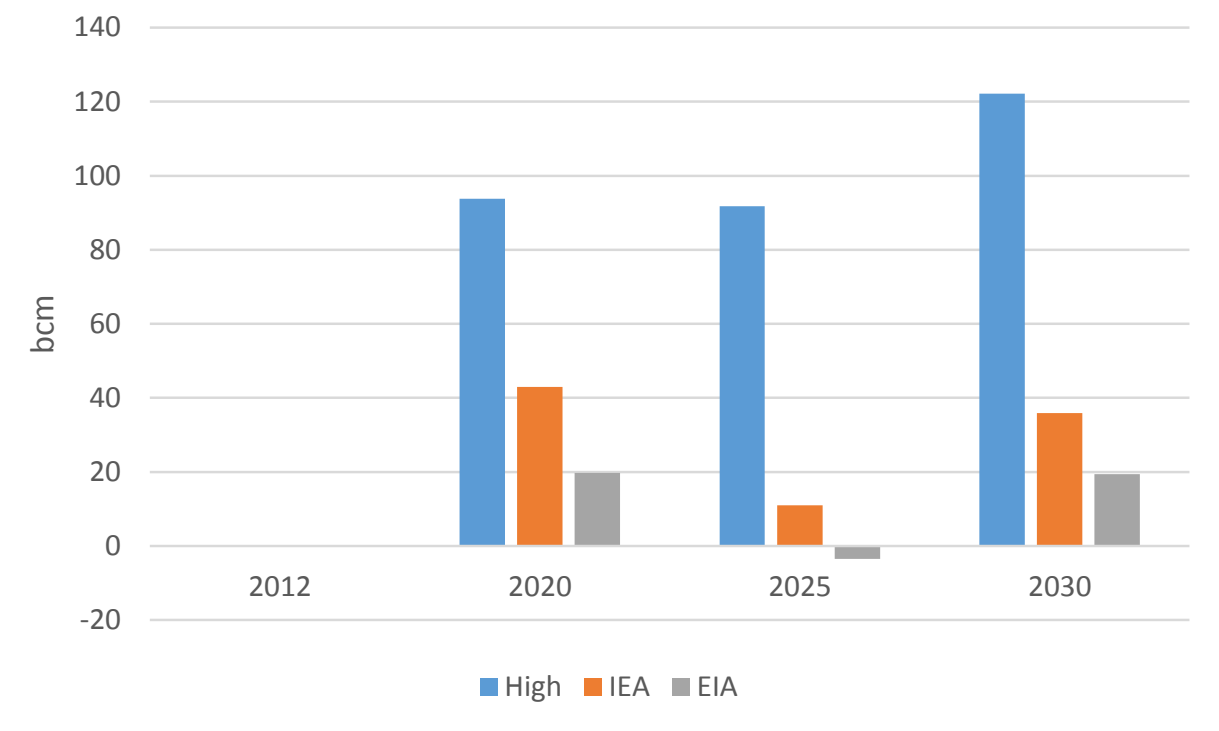

Source: Author's calculations based on assumptions outlined above 

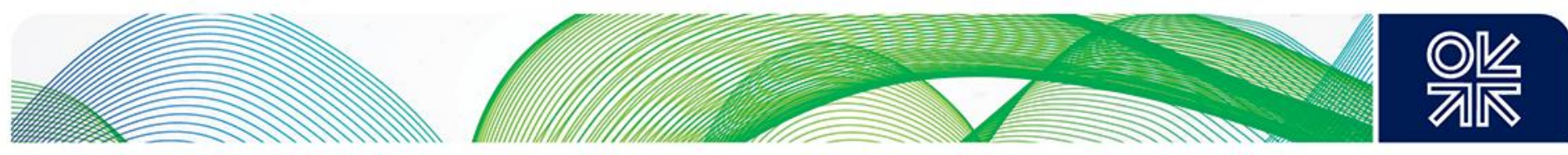

Two conclusions immediately emerge from the analysis. Firstly, the Russian share of total Chinese gas imports is above $35 \%$ between 2020 and 2030 in both the EIA and IEA cases, and is above one quarter even in the high import requirement case. This is likely to be uncomfortably high for the Chinese authorities as they consider the risk of reliance on one source. The second, and perhaps more definitive conclusion, is that the demand for non-Yamal LNG is very low in both the IEA and EIA cases, disappearing completely in 2025 and only reaching $20 \mathrm{bcma}$ in the IEA case by 2030 . Given the regasification plans outlined above and the existing contracts in place this would seem to be an untenable outcome, especially as it also reduces the flexibility of China's import purchases and keeps the share of LNG in the import mix at very low levels for the next fifteen years. Only in the high import case does LNG play anything close to the role that current investments in China would suggest is the target, and as noted above this high import scenario is itself questionable because of the overall security of supply risk it entails.

As a result, a final conclusion on the plans for Russian gas would suggest that the Chinese gas market may well not be ready for both pipeline supply routes on the currently proposed timetable. It is possible that one could start around the end of this decade and ramp up to full capacity by 2025, but the second would not appear to fit comfortably before 2030 at the earliest, unless Chinese gas demand expands rapidly and domestic supply disappoints. Given the uncertainty surrounding both assumptions at the present time, it would seem unlikely that the Chinese authorities would be prepared to gamble by signing two concrete Russian deals in 2014/15, unless the terms were so attractive as to be utterly compelling. As a result, Gazprom finds itself in a difficult negotiating position as it tries to balance its own needs with the objectives of its domestic government, the Chinese gas purchaser CNPC and the Chinese authorities.

The one major caveat to this analysis would be the lack of clarity over the elasticity of demand in China, as the country continues to consider its gas pricing policy. In early 2015 the domestic price appeared to be uncompetitively high relative to the low oil-linked LNG prices on offer in the global market, and demand growth has been affected. ${ }^{60}$ However, the Chinese authorities are already considering an adjustment, ${ }^{61}$ and it remains to be seen if this can catalyse a return to strong gas demand growth. This could be vital for Russia's gas export prospects, as even an increase of $1 \%$ /annum to the IEA growth forecast could add $75 \mathrm{bcm}$ to overall Chinese gas demand in 2030, with a potentially significant impact on the country's import requirement.

\section{Russia and China have been negotiating for a long time, in particular about price}

Russia first initiated contact with China concerning gas exports in the early 1990s, but a lack of Chinese demand and uncertainty over who actually controlled East Siberian gas reserves meant that no concrete negotiations could take place until 2004, when Gazprom signed a first memorandum of understanding with CNPC. ${ }^{62}$ Further progress was then made in 2007, when Gazprom acquired the Kovykta field from TNK-BP and could offer a concrete source of gas supply to China, but negotiations continued to drag on for a further seven years, with the constant theme being that all the details of a contract had been resolved apart from the price. A second recurring theme was the debate over which pipeline route should be used to send the supply, either an eastern route from East Siberia to NE China (preferred by China) or a western route from West Siberia through the Russian province of Altai to the Xinjiang province in western China (preferred by Gazprom and Russia). While these discussions were continuing Russia was also developing its Eastern Gas Programme, which planned

\footnotetext{
60 O'Sullivan, S., 22 June 2015, "Chinese gas prices are heading lower”, Trusted Sources Energy Blog at http://www.trustedsources.co.uk/blogs/china/chinese-gas-prices-heading-lower, sourced on 29 June 2015

O'Sullivan, S., 8 June 2015, "Is a summer gas price cut looming in China?", Trusted Sources Energy Blog at http://www.trustedsources.co.uk/blogs/china/is-a-summer-gas-price-cut-looming-in-china-with-medium-term-benefits-for-thesector sourced on 4 Sept 2015

${ }^{62}$ For a detailed history of Sino-Russian gas negotiations see Henderson (2011b) pp.6-10
} 

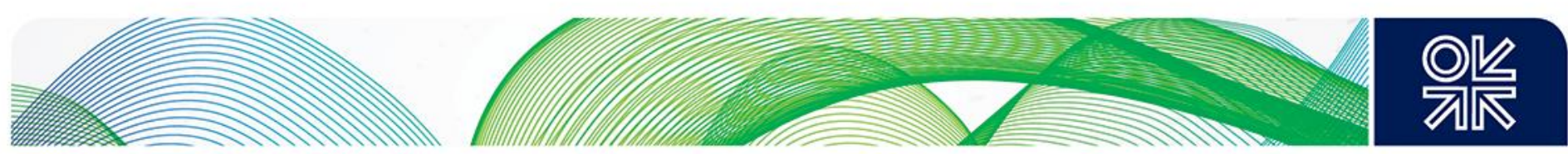

to incorporate the development of East Siberian gas reserves for export to China, for the expansion of the domestic market in Russia's Far East and for a potential LNG development at Vladivostok. ${ }^{63}$

Arguments over price continued to prevent an export agreement with China being reached, however. Russia consistently argued for a price linked to the Japanese Customs Cleared (JCC) price, equivalent to the high prices being achieved for LNG exports to Japan at the time, while China insisted on a much lower price based on its domestic market tariffs and the fact that it viewed the Russian gas as stranded with no alternative market but China. Rising oil prices in the period 20102014 meant that at times the price disparity between the two negotiating parties was as much as $\$ 100 / \mathrm{mcm}$ (c. $\$ 3 / \mathrm{mmbtu}$ ), ${ }^{64}$ providing little hope for a final agreement despite the clear strategic logic for a deal. The catalyst that was required, perhaps not surprisingly in a deal of such strategic importance, was political, and this arrived in early 2014 with the Russian annexation of Crimea, the start of the conflict in Eastern Ukraine and the consequent geo-political dispute between Russia, the EU and the US which ultimately led to the imposition of sanctions in July and September 2014. Rising tension between Russia and the West, and the perceived threat of a third Ukrainian gas transit interruption (following the previous events in 2006 and 2009) led the EU to prioritise the issue of diversification away from Russian gas, inspiring the need for a political response from Russia. ${ }^{65}$ The ideal riposte would be an alternative export route that could not only replace the potential decline in Russian sales to Europe, but might also be used as a threat from Russia to the long-term future of Russian sales to the West, and with this in mind President Putin became a driving force behind the finalisation of a gas sales agreement with China. This was partially achieved in May 2014, with an agreement being reached to supply a plateau of $38 \mathrm{bcma}$ for 30 years from fields in East Siberia through the Power of Siberia pipeline into NE China via the Russian border point at Blagoveshchensk. ${ }^{66}$ This offered a new export market for Russian gas and a diversification from sales to Europe, although it did not provide the additional threat of a possible displacement of future sales to the West, as the gas would come from a source not linked to the existing export pipelines. Nevertheless, it marked the first step in Russia and Gazprom's shifting export strategy.

\section{The complexities of Russia's gas deals with China}

However, the bald facts of the supply agreement, which is scheduled to ramp up to its peak over five years from 2019, disguise a subtle political and commercial balancing act and a complex matrix of operational, technical, financial and geo-political issues which create continuing risks for Gazprom's plans. What seems very clear, though, is that in the political circumstances of May 2014 Russia was forced to make concessions on price and pipeline route as the Chinese negotiators exploited their strong bargaining position. The latter clearly understood the necessity for Russia to sign a deal in order to provide a counterbalance to the inclination of European governments to diversify away from Russian gas. Figure 12 demonstrates how the Power of Siberia deal could compensate for a potential decline in European sales should the current long-term contracts between Gazprom and its western customers be run to expiry at the minimum take or pay level. By 2024 total export sales from Russia would return to their 2014 level of just over $140 \mathrm{bcm}$, even in a worst case scenario in Europe.

\footnotetext{
${ }^{3}$ http://www.gazprom.com/about/production/projects/east-program/ accessed on 1 June 2015

64 Interfax, 11 Oct 2010, "Russia, China remain at odds over gas routes"

${ }^{65}$ Financial Times, 27 April 2014, "Europe seeks alternative gas supplies"

${ }^{66}$ Financial Times, 21 May 2014, "China and Russia sign \$400bn gas deal"
} 

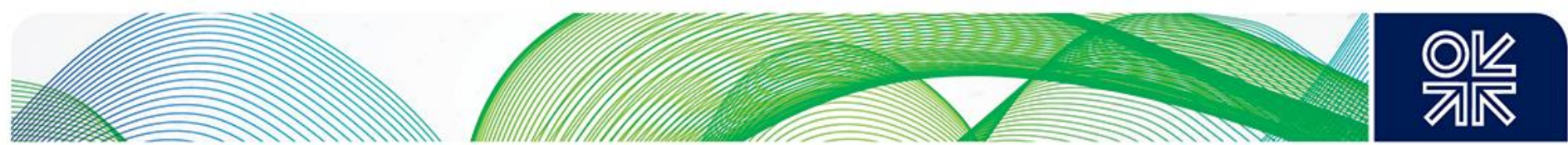

Figure 12: Potential impact of new Asian contracts on Russian gas exports in a worst case scenario in Europe

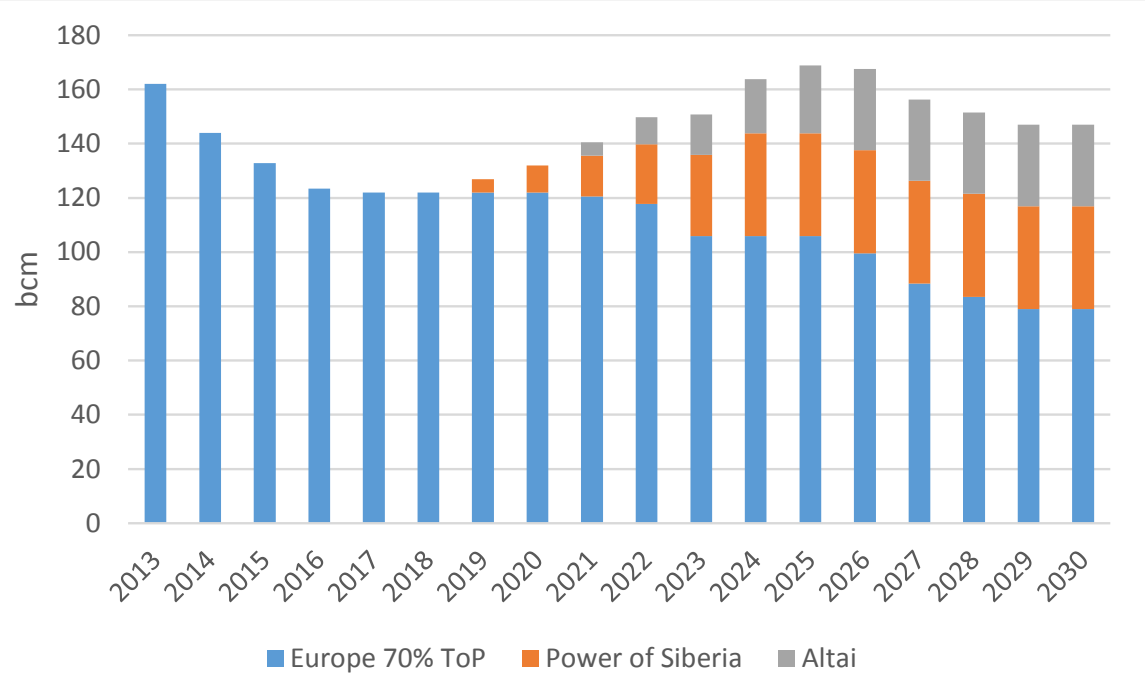

Source: Authors' analysis

In order to achieve both the political goal of demonstrating to Europe that Russia was not completely reliant on its gas demand and the commercial goal of establishing a quasi-insurance policy for a possible loss of western sales, Russia, via its state-controlled gas company Gazprom, ${ }^{67}$ had to first concede that the eastern export route preferred by China would proceed ahead of its own preferred western route, and also had to offer a price competitive with China's own alternative suppliers. This meant adjusting the traditional Asian contract terms (which normally relate to the JCC oil price), and also forgoing any hope of negotiating an aggressive slope ${ }^{68}$ such as the one that was generating LNG prices in the range of $\$ 15-17 / \mathrm{mmbtu}$ at the time the agreement was signed. Instead, Gazprom was forced to agree to a price of around $\$ 10 / \mathrm{mmbtu}$ at the Russia-China border linked to Singapore oil product and LPG prices (the official price has never been disclosed). ${ }^{69}$ This equates to a delivered price of around $\$ 12-12.50 / \mathrm{mmbtu}$ after transport costs to the eastern seaboard of China have been added (at an oil price of approximately $\$ 109 /$ barrel in May 2014). ${ }^{70}$ This lower price was an effective acknowledgement that Russian gas needed to be priced in competition with Central Asian imports as well as current and future LNG supplies. In May 2014 the delivered price of Turkmen gas to Shanghai was estimated at $\$ 13.50 / \mathrm{mmbtu}$, while the average contracted $L N G$ import price at the time was $\$ 11.40 / \mathrm{mmbtu}$ and the LNG spot price was approximately $\$ 16.50 / \mathrm{mmbtu} .{ }^{71}$ Importantly the Chinese domestic price was in a range of $\$ 10-14 / \mathrm{mmbtu}$, set partly by a market-oriented mechanism in Shanghai and partly by a lower regulated price for existing customers. ${ }^{72}$ As a result, the agreed Russian gas price seems to have been set at a level that could provide competitive gas for China into regions in the east of the country where demand is highest. According to the authors' calculations, it also provided a price at which Gazprom could make a low but politically acceptable rate of return

\footnotetext{
67 The Russian government has a $50.2 \%$ stake in Gazprom, giving it overall control

68 The slope, in LNG contract terms, is the relationship between the gas price in $\$ / \mathrm{mmbtu}$ and the oil price in $\$ / \mathrm{barrel}$. A standard slope would be around $14.5 \%$, meaning that at a $\$ 100$ oil price the gas price would be $\$ 14.50 / \mathrm{mmbtu}$.

${ }^{69}$ Alexei Miller announced a total value of the deal at $\$ 400$ bn for just over $1 \mathrm{tcm}$ of total gas sales, implying a price of around $\$ 11 / \mathrm{mmbtu}$, but later discussions with officials on both sides suggest that a price of $\$ 10 / \mathrm{mmbtu}$ is a more accurate reflection of the real price.

${ }^{70}$ Oil price for Russian export blend as reported in Argus FSU Energy on 22 May 2014, p.1

${ }^{7}$ Chen (2014), p.7

72 Henderson (2014), p.9
} 

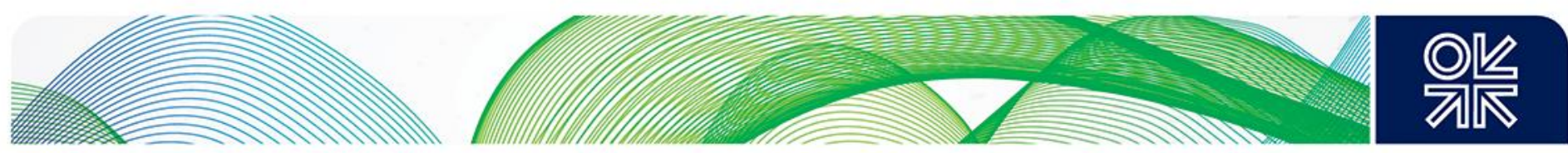

(around $8 \%$ real) on its investment of $\$ 55-70$ billion given that the upstream and midstream facilities would provide the foundation for the development of Russia's Eastern Gas Programme. ${ }^{73}$

Another significant element of the eastern gas deal was that it initially included the promise of $\$ 25$ billion of financing from China, effectively to underpin the cost of the Power of Siberia pipeline. ${ }^{74}$ Gazprom had initially refused to include the financing deal in the supply agreement in order to separate it from any pricing discussions, and as a result further negotiations over any loan agreement were bound to take place after the May agreement had been signed. However, the first signs that the Power of Siberia deal might not be as robust as expected started to emerge as the financing discussions dragged on, before Gazprom eventually announced that they had been cancelled in November 2014. ${ }^{75}$ This was a particular surprise because, as discussed above, Gazprom has been struggling to raise money on international markets and was also being hurt by the decline in the oil price and the consequent fall in its gas export prices. Indeed evidence for the problems with financing "Power of Siberia" have since become stronger, as on August 10, 2015 President Putin signed a special decree on measures to implement the agreement between Russia and China on gas supplies ${ }^{76}$, including the order to develop a complex plan for state support of the pipeline construction, implying that Gazprom may not be able to provide financing alone. On a more positive note, though, Gazprom has announced a near halving of the initial price of the tender for the construction of the second $94 \mathrm{~km}$ part of the pipeline, ${ }^{77}$ implying that the benefits of rouble devaluation are helping to cut costs and reduce the overall level of financing that may be needed. Nevertheless, the announcement by Gazprom CEO Alexei Miller and Russian President Vladimir Putin that negotiations were starting immediately on the western "Altai" delivery route straight after the May 2014 agreement immediately raised questions as to how Gazprom could hope to finance these two Asian pipelines as well as its promised Black Sea export pipeline (originally South Stream to Bulgaria but now Turkish Stream to Turkey)..$^{78}$

\section{Russia's shifting priorities}

One initial conclusion was that, if forced to prioritise, the Russian parties might prefer to delay Power of Siberia and advance the Altai pipeline in its place, and there are a number of reasons for believing that this may have been the case. Firstly, as mentioned above, the western route via Altai has always been the Kremlin and Gazprom's preferred route, as it has political and commercial advantages. ${ }^{79}$ From a political perspective, it is the route which does link a single source of (already developed) gas (in West Siberia) to both the European and Asian markets, offering some leverage in the longer term as a potential "threat" to either or both customers if they try to undermine Russia's position. From a commercial perspective the Altai route can help Gazprom to use its excess gas supply in West Siberia, which can both help to improve the balance in the domestic market and also to provide very low cost gas supply for exports, which will be needed if the company is to offer a competitive price once the gas has reached eastern China, given the vast distances involved. The upstream development cost will effectively be zero, while the cost of the pipeline, which for much of its journey will run alongside existing UGSS ${ }^{80}$ infrastructure, will be lower than Power of Siberia (Altai is

\footnotetext{
${ }^{3}$ Pre-rouble devaluation the upstream capital expenditure was put at $\$ 25$ billion, the cost of the Power of Siberia pipeline at $\$ 27$ billion. The cost of the gas processing plant is estimated at $\$ 20$ billion, although this includes helium processing that may not be carried out by Gazprom. Nevertheless, the total capital expenditure could be as high as $\$ 72$ billion, although at an exchange rate of RR54=US\$1 this could be reduced significantly, depending upon how much of the equipment is sourced domestically

${ }^{74}$ Reuters, 23 May 2014, "Russia, China agree on \$25 billion prepayment under supply agreement"

75 Interfax, 10 Nov 2014, "Gazprom not considering advance for Power of Siberia to further reduce price"

${ }^{76}$ Kremlin.ru/acts/news/50116

77 www.anfi.ru/news.shtml\&oid=2828118

${ }^{78}$ Natural Gas Europe, 23 May 2015, "Russia/Gazprom: Commercial realities coming to the fore"

${ }^{79}$ Note that the Altai pipeline has now been renamed Power of Siberia-2, but for clarity we have retained the original nomenclature. The Altai route refers to the western pipeline from West Siberia to Western China, while Power of Siberia refers to the eastern route from East Siberia to NE China.

${ }^{80}$ Russia's internal trunk pipeline system is known as the United Gas Supply System or UGSS
} 

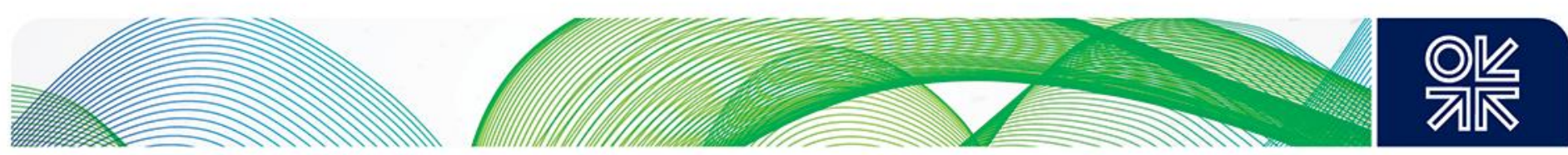

estimated to cost $\$ 10-\$ 20$ billion versus $\$ 27$ billion for Power of Siberia). In contrast, development of the eastern route will involve not only the cost of the pipeline but also the significant cost and difficulty of developing the Chayanda and Kovykta gas fields, as well as the very large and complex gas processing plant that will be needed to provide suitable quality gas and strip out the large quantities of helium that will be produced at both fields. From a political perspective the East Siberia fields do not provide the same implied threat to Europe, as they are not connected to the western export pipelines, and so the gas exports really only act as a balance in the case of a decline in European sales. The Altai route however, offers the opportunity (however theoretical) to suggest that exports to China could undermine the European market.

From a Russian perspective, then, there is significant circumstantial evidence to suggest that, even though the eastern sales contract was signed first, and in the presence of the Russian and Chinese leaders, and the pipeline has now started to be built on both sides of the border, ${ }^{81}$ a change of plan could be a desirable outcome. In particular this is likely to be driven by the economics of the Power of Siberia project in the light of the fall in the oil price from $\$ 115 / \mathrm{barrel}$ to $\$ 50 /$ barrel, which must have reduced the gas price agreed in May 2014. Although no contractual details have been revealed, and it is unlikely that the gas price and oil price will have moved on a 1-to-1 basis as "kink points" are usually included in contracts to mitigate the impact of very low or high oil prices, it is probably safe to assume that the gas price has fallen from the initial $\$ 10 / \mathrm{mmbtu}$ to around $\$ 6 / \mathrm{mmbtu}$ in August 2015 . Although it is obvious that the price may have recovered by the time that the gas is actually produced, and it is also the case that the devaluation of the rouble has reduced capital expenditure, around $80 \%$ of which is likely to be in roubles, nevertheless the economics of the East Siberian gas export project have certainly been undermined. Our economic model suggests that at a gas price of $\$ 6 / \mathrm{mmbtu}$ at the Russian border Gazprom's rate of return falls to only $5 \%$ real assuming a rouble exchange rate of RR60 $=U S \$ 1$ and a consequent total capital expenditure of $\$ 44$ billion. These numbers clearly do not make the project financially attractive for Gazprom, even on the assumption that the relatively generous capital expenditure assumption is correct, and provide another reason why Gazprom might prefer the western route.

From a practical perspective, there is also evidence to suggest that progress in the development of the eastern route has been slow. Despite the announcement that the first section of the Power of Siberia line was welded in September 2014,82 and subsequent announcements that adequate progress is being made, ${ }^{83}$ Gazprom's latest plans show that only $43-50$ kilometres of pipe are planned to be laid in $2015 .{ }^{84}$ Given that the line stretches for almost 2,400 kilometres it seems barely credible that it could be completed by 2019, even if 2015 is largely spent in preparatory work. In addition, work at the Chayanda field is still at a relatively early phase on a structure that Gazprom itself admits is both geologically complex, remotely located and in a harsh environmental setting. ${ }^{85}$ Geological work will only be completed in 2015 , at which point the field's oil rim is set to be developed in advance of the gas reserves that will be needed to fulfil the export contract. An additional complication will be the utilisation of the field's large helium reserves, which as a valuable commercial and strategic resource must be separated and stored for sale. This will involve the construction of both a huge processing plant and a helium plant, the total cost of which is estimated at $\$ 10-20$ billion, with a further problem being that much of technology for the helium plant can only be supplied by foreign companies. ${ }^{86}$ Although this equipment is not currently sanctioned, the sanctions regime is causing a reluctance among foreign suppliers to deal with Russia that can cause delays, while the rouble devaluation has increased the cost importing such expensive equipment into Russia.

\footnotetext{
${ }^{81} \mathrm{http}: / /$ russian.rt.com/article/95140

${ }^{82}$ Gazprom Press Release, 1 Sept 2014, "Power of Siberia construction launched"

83 Oil and Gas Technology, 23 Mar 2015, "Chayanda and Power of Siberia will be completed right on time, says Gazprom chief"

${ }^{84}$ Oil and Gas Eurasia, 20 May 2015, "China's CNPC will begin the construction of the Power of Siberia leg on its territory in June"

${ }^{85}$ Gazprom web site at http://www.gazprom.com/about/production/projects/deposits/chayandinskoye/, accessed on 26 May 2015

${ }^{86}$ Interfax, 15 May 2015, "Gazprom helium projects in East threatened by sanctions"
} 

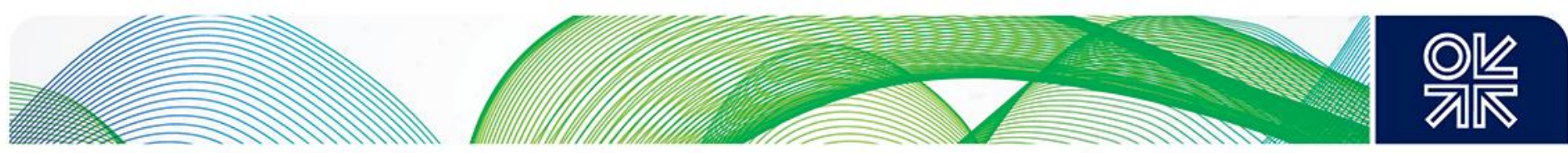

Even if these problems can be resolved to allow Chayanda production to begin in 2019, the field does not have adequate production capacity to meet the $38 \mathrm{bcma}$ peak supply requirement on its own, as maximum production is estimated at $25 \mathrm{bcma}$. As a result Gazprom will also need to develop the Kovykta field to the south in the Irkutsk region and to connect it via an additional 800 kilometre pipeline to Chayanda. This is planned to take place by the mid-2020s when sales to China are scheduled to reach their maximum level, but presents Gazprom with another problem because it only needs to develop a small proportion of Kovykta's 35bcma production capacity to meet the Chinese export requirement. Partial development of the field is of course possible, but an alternative plan has been put forward by various independent producers led by Rosneft that non-Gazprom gas should be given access to the Power of Siberia pipeline and possibly some form of access to the Chinese export market. ${ }^{87}$

\section{Gazprom's position challenged by domestic competitors}

This challenge to Gazprom's pipeline export monopoly has been rebuffed by Alexei Miller, the company's CEO, who stated that "the Power of Siberia pipeline and export supplies to China were planned only for Gazprom's resource base", 88 but nevertheless Rosneft has threatened a legal challenge if its gas is not allowed into the pipe. ${ }^{89}$ Indeed the Russian state oil company went as far as to suggest that it had significant gas reserves waiting to be produced and that other independents also have further potential for gas supply in the region. ${ }^{90}$ Furthermore the company's CEO Igor Sechin proposed to the Government Energy Commission that the issue of gas exports to China by independent producers should be considered, ${ }^{91}$ clearly demonstrating that the debate over Power of Siberia is an extension of a broader challenge to Gazprom that has been emerging in the East of Russia.

Specifically, Gazprom's monopoly over exports has been undermined in the LNG market, where its own plans have not materialised while the government has increased its support for alternative Russian options. In December 2013 the Russian government granted permission for projects operated by Novatek and Rosneft to sell their output in overseas markets, ${ }^{92}$ providing direct competition to Gazprom's plans to expand its existing project on the island of Sakhalin (Sakhalin 2) and to build a new plant at Vladivostok. However, the reality since then is that all three companies' plans have been set back to varying degrees by a combination of political and commercial issues. The details of Russia's LNG strategy in both eastern and western markets will be discussed below in Part 3, but as far as the Asian market is concerned it is sufficient to state that the impact of US and EU sanctions, in particular on the ability of Russian companies to raise long-term finance, and the fall in the oil (and as a result gas) price in Asia have undermined Russia's prospective LNG projects in the East. ${ }^{93}$ Novatek's Yamal LNG project has been hindered by problems securing project financing, although the scheme is still likely to proceed before the end of the decade, ${ }^{94}$ while Rosneft is having to re-prioritise its Far East LNG project on Sakhalin Island. ${ }^{95}$ Perhaps most significantly, though, Gazprom has announced the deferral of Vladivostok LNG ${ }^{96}$ and it now seems that plans to add a third LNG train at Sakhalin 2 are also under threat due to an extension of the US sanctions regime to

\footnotetext{
${ }^{87}$ Financial Times, 3 July 2014, "Putin suggests ending Gazprom pipeline monopoly"

88 Business New Europe, 10 July 2014, "Battle of the gas giants"

89 Rosneft press release, 1 July 2014, "Rosneft Announcement Regarding Gazprom Position on the Admission of Independent Gas Producers to the Major Gas Pipeline Network"

90 TAAS, 22 May 2014, "Rosneft ready to lay main pipelines in Eastern Siberia - CEO"

91 Interfax, 5 June 2014, "Russian govt. considering two options for possible export of eastern gas by independents"

92 Financial Times, 22 Nov 2013, "Russia paves way for limited liberalisation of LNG exports"

${ }^{93}$ Hague Centre for Strategic Studies, 29 Oct 2014, "Russian LNG projects hit hard by sanctions"

${ }_{94}^{4}$ Financial Times, 31 Dec 2014, "Russia takes steps to prop up struggling companies"

95 Reuters, 7 April 2015, "Rosneft's Sakhalin LNG plant delayed for at least two years - sources"

${ }^{96}$ Bloomberg, 19 June 2015, "Gazprom said to weigh delaying LNG spending on China Link costs"
} 

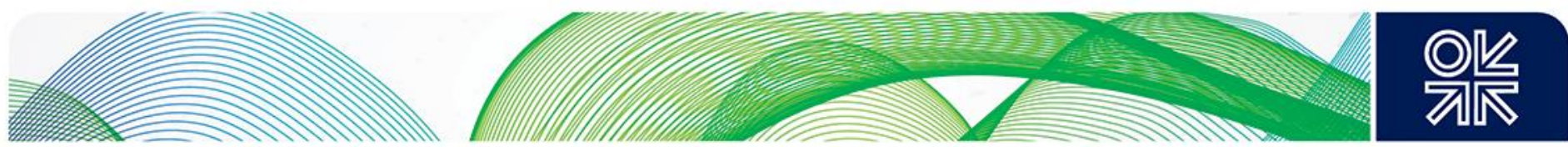

include a field at the Sakhalin 3 licence that was to have been the source of extra gas needed for the new project. ${ }^{97}$

\section{Map 1: Russia's Eastern Gas Programme, including Pipeline and LNG developments}

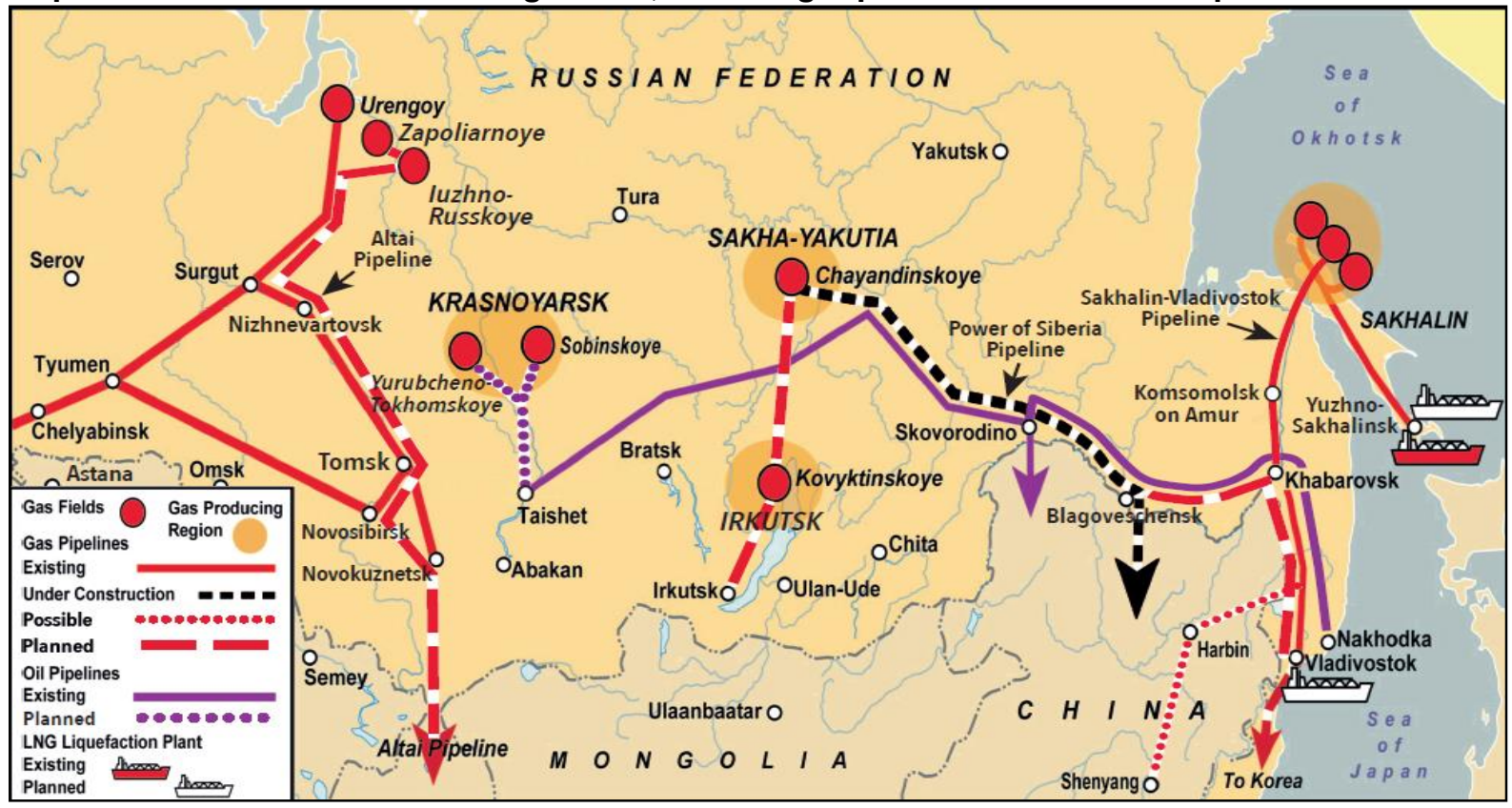

Source: OIES, Gazprom

The switch away from LNG development has allowed Gazprom to refocus on its more traditional skill of exporting gas via pipeline and building the export infrastructure to achieve this. The postponement of Vladivostok LNG has, however, had one important impact on the eastern export strategy in that it has removed one of the reasons for actively pursuing the Power of Siberia route, which had originally been planned to end on the Pacific Coast. It now appears that, at least for the foreseeable future, the pipeline will end at the Chinese border at Blagoveshchensk, reducing not only Gazprom's export options but also its ability to complete the domestic elements of the Eastern Gas Programme. When these strategic factors are added to the technical and financial problems highlighted above, it is easy to see why Russia and Gazprom would prefer to prioritise the western Altai route. Indeed it has even been suggested that active discussion about the postponement of Power of Siberia has been taking place, as Russia actively tries to persuade the Chinese authorities to consider the western route first. 98

Nevertheless, although the logic for Gazprom and Russia to prioritise the Altai pipeline is clear, China will need to see some obvious benefits if it is to allow gas to be delivered to its western provinces before its north-east region receives Russian gas. From a strategic point of view the logic of such a move from a Chinese perspective is opaque to say the least. As previously discussed, the Chinese gas demand outlook for 2020 appears less optimistic than previously forecast, meaning that the need for imported gas overall is likely to be less than expected by this date. It would therefore make sense to receive gas where it is most needed, on the eastern seaboard where the major energy demand centres are located or in the north east where gas can help to replace extensive coal consumption, thus easing some of China's environmental burden. ${ }^{99}$ The relative proximity of Blagoveshchensk to these locations means that CNPC can afford to offer a higher price for gas delivered there, due to the lower transport cost from the border delivery point to market. It is estimated that the cost of moving

\footnotetext{
97 Reuters, 10 Aug 2015, "US sanctions put Gazprom-Shell alliance plans in jeopardy"

${ }_{99}$ Reuters, 18 Mar 2015 , "Russia could postpone gas pipeline to China touted by Putin - sources"
} 

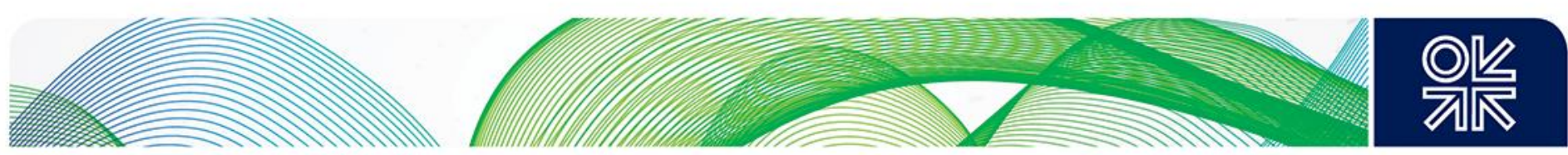

gas from the border in NE China to Shanghai, for example, is around $\$ 2-2.50 / \mathrm{mmbtu}$, compared to $\$ 4.50 / \mathrm{mmbtu}$ from the western delivery point of the proposed Altai pipeline. ${ }^{100}$

Furthermore, CNPC already receives a growing amount of imported gas in its western region of Xinjiang from Central Asia, and also has a large source of domestic supply in the area. The main trunk pipeline system which brings this gas to the east coast, the West-East Pipeline (WEP), is already in operation, with WEP 1 bringing $17 \mathrm{bcma}$ of domestic gas supply across the country, while WEP 2 has 30bcma of capacity allocated to Central Asian imports, mainly from Turkmenistan. ${ }^{101}$ WEP 3 is due to be completed in 2016-17 with a further $30 \mathrm{bcma}$ of capacity to take the planned increase in Central Asian gas imports, and a further three WEP strings are then planned, as gas demand continues to increase. In terms of potential sales from Russia via Altai, it will therefore be important to see which string gets allocated to gas from that source. At present its seems that WEP 4 will be used for increased domestic supply from the Tarim Basin, WEP 5 will take yet more Caspian gas as Turkmen supply peaks at $65 \mathrm{bcma}$ and $10 \mathrm{bcma}$ comes from each of Uzbekistan and Kazakhstan, while WEP 6, which is unlikely to appear before the early 2020s, will be for Russian gas. When one combines this outlook with the fact that CNPC has already begun construction of its part of the Power of Siberia route on the Chinese side of the border, then it looks rather unlikely that China will be prepared to take Altai gas from Russia first. ${ }^{102}$

However, there are four possible arguments that could see the Chinese persuaded to shift their position and contemplate either a re-prioritisation or the conclusion of a second deal to add Altai gas to its import portfolio in addition to Power of Siberia.

- The first concerns the amount of gas set to come from Central Asia, in particular because the $20 \mathrm{bcma}$ due from Uzbekistan and Kazakhstan is far from secure, as highlighted by Pirani (2012). Uzbekistan has significant domestic demand, and is unlikely to have sufficient surplus to meet Chinese requirements, while Kazakhstan may also use any extra gas production internally while focussing on its growing oil production for export. This would leave a potential gap for Altai gas rather earlier than anticipated, and would also allow Russian gas to compete with supply from Central Asia in a manner which could helpfully increase China's bargaining position with both regions.

- Secondly, China's recently developed "New Silk Road" strategy, otherwise known as "One Belt, One Road", 103 could also encourage new gas supplies in the west from Russia. As China implements its goal to stretch its influence towards Europe and SE Asia via transport and infrastructure routes in its western provinces, it would make sense to tie in as many countries as possible, and certainly not to leave out a potential major partner in Russia, which has its own Eurasian project that could compliment or compete with China's strategy. ${ }^{104}$

- Thirdly, any new competitively priced gas can help to encourage the economic development of Xinjiang, which is a key goal for the Chinese authorities as it develops the Xinjiang Circular Gas Grid. ${ }^{105}$

- And finally, CNPC could be offered equity in upstream fields supplying gas into the pipe, which could act as a major incentive to get a deal done as it would mirror the Chinese strategy in many countries around the world where it has invested in the energy assets that supply its market.

\footnotetext{
100 Henderson (2014), p.9

101 Paik (2015), p.27

102 Interfax, 1 June 2015, "China begins to build extension of Power of Siberia, ceremony for welding first join at end of June"

${ }^{103}$ Financial Times, 4 May 2015, "China must prove Silk Road plan is serious"

104 Foreign Affairs. 19 April 2015, "China's Road Rules"

105 Paik (2015), pp.27-28
} 

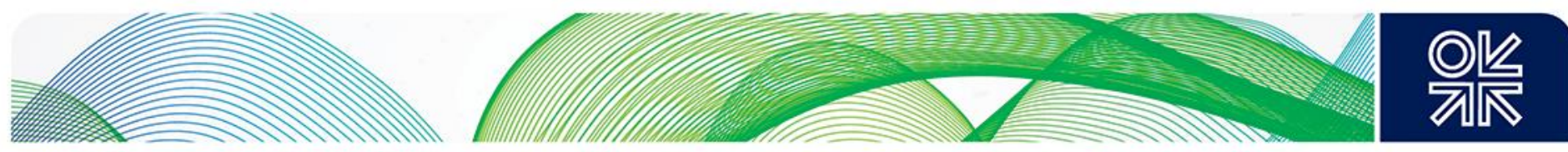

\section{Can Altai gas make economic sense?}

However, these three arguments in favour of Russian gas via Altai would all fail to be persuasive if a fifth argument cannot be made by Gazprom to provide a competitive source of supply from Russia. In Henderson (2014) an initial analysis showed that a price of $\$ 9.50 / \mathrm{mmbtu}$ at the Russia-China border in the west could have allowed Altai gas to compete with China's various alternative sources of supply, while also giving Gazprom a similar netback to its gas sales in Europe. ${ }^{106}$ However, this calculation was carried out using gas prices based on a $\$ 100+$ oil price, and although in a relative sense the comparison is still valid the absolute figures have been made irrelevant by the decline in oil to around $\$ 50-60 /$ barrel in the summer of 2015 . Table 2 therefore attempts a more current benchmarking process for Altai gas, assuming a decline in gas prices in line with the oil price fall (the table assumes a $\$ 55$ oil price).

Some of the prices are directly verifiable from current sources, that are noted, but others such as the Turkmen and Myanmar import prices are less transparent and have therefore been calculated from earlier data. For example, the Turkmen import price has been calculated on a pro rata basis from the average 2013 price of $\$ 9.60 / \mathrm{mmbtu}$ quoted by Chen (2014) when the average oil price was $\$ 108 /$ barrel, while a similar adjustment has also been made for the Myanmar price based on an original price of $\$ 11.75 / \mathrm{mmbtu}$ related to the 2013 oil price. ${ }^{107}$ The Chinese domestic price in Shanghai reflects the latest adjustment made by the Chinese regulator in April 2015. ${ }^{108}$

Table 2: Benchmark of Chinese Gas Import Prices for Potential Altai Gas Supply (Netbacks to Russia/China Border)

\begin{tabular}{|c|c|c|c|c|c|}
\hline & $\begin{array}{c}\text { Price at entry } \\
\text { to China }\end{array}$ & $\begin{array}{c}\text { Transport } \\
\text { to } \\
\text { Shanghai }\end{array}$ & $\begin{array}{c}\text { Price in } \\
\text { Shanghai at } \\
\text { City Gate } \\
\text { US\$ } / \mathrm{mmbtu}\end{array}$ & $\begin{array}{c}\text { Transport } \\
\text { back to } \\
\text { Xinjiang } \\
\text { US\$/mmbtu }\end{array}$ & $\begin{array}{c}\text { Net back } \\
\text { price at Altai } \\
\text { pipeline } \\
\text { entry point } \\
\text { US\$ } / \mathrm{mmbtu}\end{array}$ \\
\hline Turkmen price in West China & 5.86 & 4.48 & 10.34 & 4.48 & 5.86 \\
\hline Russia East Siberia Gas & 6.06 & 2.50 & 8.56 & 4.48 & 4.08 \\
\hline Asia Spot LNG (May 2015) & 7.80 & 0.00 & 7.80 & 4.48 & 3.32 \\
\hline Average LNG imports (Jan-Feb 2015) & 10.71 & 0.00 & 10.71 & 4.48 & 6.23 \\
\hline Qatar LNG & 15.58 & 0.00 & 15.58 & 4.48 & 11.10 \\
\hline US LNG (HH \$5/mmbtu) & 10.45 & 0.00 & 10.45 & 4.48 & 5.97 \\
\hline Myanmar imports & 6.95 & 1.85 & 8.80 & 4.48 & 4.32 \\
\hline Benchmark Import Price & & & & & 5.84 \\
\hline Shanghai city-gate price (2015) & 12.18 & 0.00 & 12.18 & 4.48 & 7.70 \\
\hline Average Overall Benchmark Price & & & & & 6.07 \\
\hline
\end{tabular}

Source: Author's Calculations based on data from Energy Intelligence Group databases

As can be seen from the table, a straight non-volume-adjusted average benchmark price to make Altai gas competitive at the Russia-China border in Xinjiang would be $\$ 5.84 / \mathrm{mmbtu}$, or $\$ 6.07 / \mathrm{mmbtu}$ if the Shanghai domestic price is excluded. The most relevant import price is probably the Turkmen border price of $\$ 5.86 / \mathrm{mmbtu}$, as this will be a direct competitor for Russian gas, while the most concerning is the benchmark for the current Asian spot LNG price, which in May 2015 was priced at

\footnotetext{
106 Henderson (2014), pp.9-10

${ }^{107}$ A $10 \%$ adjustment has also been made to allow for the fact that the relationship between the gas and oil price in most gas contracts is not linear, and makes allowances for lower oil prices. In this case the authors have assumed that the gas price will be $10 \%$ higher than would have been the case in a straight line calculation.

${ }^{108}$ Reuters, 2 Mar 2015, "China's city-gate natural gas prices by province"
} 

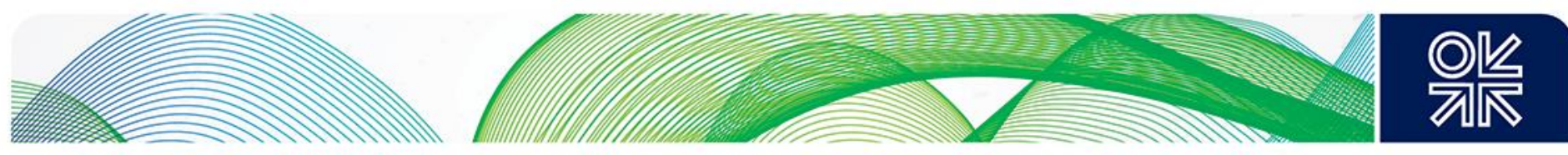

below $\$ 8 / \mathrm{mmbtu}$ on China's eastern seaboard, ${ }^{109}$ equivalent to only $\$ 3.32 / \mathrm{mmbtu}$ when netted back to the entry point for Russian gas via Altai in the West. On a more encouraging note, though, the current domestic gas price in Shanghai of just under $\$ 12.20 / \mathrm{mmbtu}$ would allow for an Altai gas price of $\$ 7.70 / \mathrm{mmbtu}$ in western China, while the most expensive gas imports (from Qatar) result in a netback price of over $\$ 11 / \mathrm{mmbtu}$. It is interesting to note, though, that the assumed price of Russian gas from East Siberia is currently one of the cheapest on offer in China, given that the agreed price of around $\$ 10 / \mathrm{mmbtu}$ was settled when the oil price was well over $\$ 100 /$ barrel in May 2014. ${ }^{110}$

The key question, therefore, is whether Gazprom can afford to offer Altai gas at a price that can compete in this new low oil and gas price world. Table 3 offers two potential answers to this question and suggests that the answer is a cautious "maybe". Under the Tariff 1 scenario the built up cost of supply is calculated from an average upstream cost of supply in West Siberia, following the devaluation of the rouble, ${ }^{111}$ of less than $\$ 0.4 / \mathrm{mmbtu}$, and a mineral extraction tax (MET) of US $\$ 0.33 / \mathrm{mcm}$. ${ }^{112}$ To this is then added an average transport tariff for the entire UGSS pipeline system of $\$ 0.68 / \mathrm{mmbtu}$, on the generous assumption that Gazprom decides to spread the cost of the Altai pipeline across its overall tariff. ${ }^{113}$ When a $30 \%$ export tax is added, the total cost of delivered gas in western China is just below $\$ 2.00 / \mathrm{mmbtu}^{114}$

At the other end of the scale, the same upstream and MET costs are added to a transport tariff that is calculated on a stand-alone basis for the Altai pipeline. A discounted cashflow model was created on the assumption that Gazprom would be prepared to accept a utility rate of return (set in this instance at $10 \%$ real) for its pipeline investment. Capital expenditure estimates for the Altai pipeline have ranged from $\$ 10$ billion to $\$ 20$ billion, ${ }^{115}$ and taking the higher estimate but adjusting for rouble devaluation on the assumption that $80 \%$ of costs will be domestic, we have assumed a $\$ 12.5$ billion total cost. On this basis the transport tariff required for the project to breakeven would be $\$ 5.25 / \mathrm{mcm} / 100 \mathrm{~km}$, equivalent to $\$ 3.92 / \mathrm{mmbtu}$. As a result, and with an increased export tax as a result of the higher delivered cost, the breakeven price on the Chinese border would be approximately $\$ 6.50 / \mathrm{mmbtu}$ (although it should be noted that both calculations could be lower if the zero MET tax concession given to Power of Siberia gas exports is extended to Altai gas). ${ }^{116}$

Table 3: The Economics of Altai Gas to Western China

\begin{tabular}{|l|cc|}
\hline US\$\$mmbtu & Tariff 1 & Tariff 2 \\
\hline Upstream Cost & 0.34 & 0.34 \\
MET & 0.33 & 0.33 \\
Pipeline Tariff & 0.68 & 3.92 \\
Export Tax & 0.58 & 1.97 \\
Total & $\mathbf{1 . 9 3}$ & $\mathbf{6 . 5 6}$ \\
\hline
\end{tabular}

Source: Authors' calculations

This range of prices would suggest that Gazprom can offer a competitive gas price to CNPC in western China, depending on how it accounts for transport tariffs. Current regulation would suggest that the transport cost should not be spread across the pipeline system as a whole, especially as this could also cause significant complaints from domestic producers who do not have access to exports.

\footnotetext{
${ }^{109}$ World Gas Intelligence, 27 May 2015, "Spot LNG: Prices edge up in Asia, down in Europe"

110 Bloomberg, 2 July 2014, "Gazprom's China gas price said to be near German level"

${ }^{111}$ We assume US\$1=RR60 throughout, although the rate in August 2015 had fallen as low as US\$1=RR64

112 Gazprom presentation to investors, June 2015, slide 25 shows an upstream cost of RR765/mcm and an MET rate of RR745/mcm in 2015

113 The transport tariff is calculated from a Gazprom presentation in June 2015 which states that the average cost of transporting Gazprom's gas in the UGSS is RR58.9/mcm/100km. Assuming a distance for the Altai pipeline of 2,666km this equates to $\$ 0.68 / \mathrm{mmbtu}$ for gas delivered to the Chinese border from West Siberia.

${ }^{114}$ Export tax is calculated as $30 \%$ of the final delivered price.

115 Siberian Times, 12 Nov 2014, "Huge new Siberia gas deal with China"

${ }^{116}$ Interfax, 22 May 2014, "Mineral extraction tax of zero for gas shipped to China essentially approved - Dvorkovich"
} 

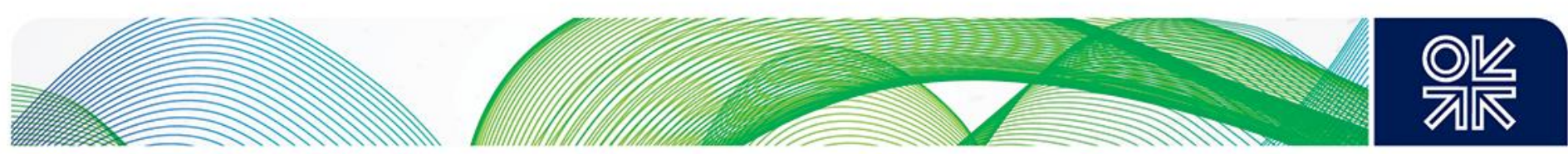

Therefore additional options could be for the Russian government to make an adjustment to the export tax or for Gazprom to accept a lower rate of return on its pipeline investment in order to bring the breakeven price down. Furthermore, Gazprom may also be prepared to offer a relatively low price in 2015, but tie it to oil product prices (as is the case for Power of Siberia) in anticipation of a higher price level once the gas starts to flow. As a result, it is certainly possible to imagine a scenario in which China could be strategically and commercially persuaded to take Altai gas sooner than anticipated.

However, despite this positive analysis it still remains very clear that China has a strong bargaining position. Its leader Xi Jinping personally finalised the Power of Siberia agreement with Russian President Vladimir Putin, and so any shift in the priority of this first deal would be a major concession and one that Putin might need to expend significant political as well as commercial capital to achieve. Furthermore, the fact that CNPC has started to build the connecting pipeline to Power of Siberia on the Chinese side of the border implies that no change in the original plan is anticipated. ${ }^{117}$ China also has plenty of supply alternatives in a global gas market that is becoming increasingly long in new LNG, as reflected in the fall in the Asian LNG spot price from over $\$ 19 / \mathrm{mmbtu}$ at the start of 2014 to the level of $\$ 7.80 / \mathrm{mmbtu}$ seen in Table 2. As a result, if Russia does push for a shift in priority for the Altai pipeline, China can either continue to negotiate in the knowledge that any delay in supply can be covered with non-Russian gas or in the expectation that the price of Russian gas will have to become even more competitive.

One further concern for Russia is whether Gazprom will be able to finance both its Asian pipeline projects, in whichever order they appear, as well as the Turkish Stream pipeline it proposes to build across the Black Sea to Europe and expansion of Nord Stream. The details of Gazprom's financial situation have been discussed above, and it is clear that over the past 12 months since the rejection of the initial CNPC proposal of $\$ 25$ billion to help finance the Power of Siberia pipeline ${ }^{118}$ the commercial environment has changed dramatically. ${ }^{119}$ Given the fall in the oil price since then and the difficulty that all Russian companies are having in raising new project financing, Gazprom may need to turn to China again for a loan and may have to offer both a competitive gas price and/or equity in upstream projects to secure any funds, especially if it wants to secure an agreement for the Altai pipeline. Historically it has been very reluctant to countenance any Chinese involvement in upstream projects, in contrast to Rosneft and Novatek who have welcomed Chinese equity participation, but this stance may have to change if Russia's eastern gas export strategy is to move ahead over the next five years. Indeed Vladimir Putin and Deputy Prime Minister Arkady Dvorkovich have both indicated a willingness to countenance Chinese investment in strategic energy assets, with the former stating that "we set no restrictions on our Chinese friends", while the latter suggested that Russia is now prepared to grant Chinese investors controlling stakes in oil and gas assets. ${ }^{120}$

\section{Conclusions on Russia's Eastern Export Strategy}

Russia's eastern gas strategy has been long in the making, and the results of 10 years' effort appeared to reach a definitive conclusion in May 2014 with the agreement between Gazprom and CNPC for the supply of $38 \mathrm{bcma}$ of gas via the Power of Siberia pipeline from 2019. However, numerous factors have complicated the situation over the subsequent 12 months, meaning that, despite the obvious commercial logic of Russian gas sales to China, doubts remain about the timing and direction of Gazprom's future eastern exports. Lowering of Chinese gas demand estimates, increased global availability of new LNG, lower gas and oil prices and the imposition of sanctions on Russia have all undermined the potential position of Russian gas in NE Asia. Indeed the failure to

\footnotetext{
117 See http://russian.rt.com/article/95140, accessed on 10 Aug 2015

118 Interfax, 21 May 2014, "Prepayment under gas contract with China possible, may total \$25bln"

${ }^{119}$ Financial Times, 5 May 2015, "Moscow offers bigger stakes in energy projects to lure Chinese"

${ }^{120}$ Financial Times, 5 May 2015, "Moscow offers bigger stakes in energy projects to lure Chinese"
} 

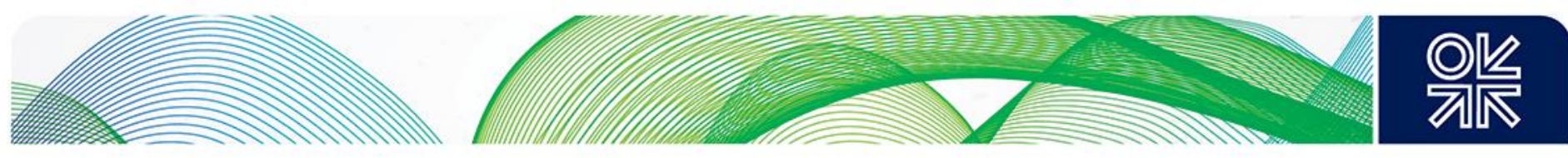

reach final agreement on the future of the Altai pipeline during President Putin's visit to Beijing in September 2015 underlined the difficulty in negotiating a deal at this time, with "commercial issues" not surprisingly remaining the key area of debate. ${ }^{121} \mathrm{~A}$ memorandum of understanding on a third pipeline, from Sakhalin in the Far East, was signed instead, but this appeared to be a face-saving move rather than the establishment of a concrete alternative plan as even Gazprom admitted that the "third priority is the study of the possibility of gas supplies from the Far East of Russia from around Vladivostok to China."122

Already Gazprom and Rosneft's LNG plans have been derailed, and now Gazprom's pipeline plans are also uncertain due to the poor economics of the Power of Siberia project at current prices. Gazprom and the Kremlin appear to have a logical preference for the cheaper Altai route in the West, which would allow Gazprom to use existing developed gas reserves in West Siberia through a cheaper pipeline to China. However, the logic for China is not so obvious, as the gas would have to travel many thousands of kilometres on its territory to reach the main demand centres. As a result, a very competitive Russian gas price would be required, but even then CNPC might decide that a delayed negotiation could only strengthen its bargaining positon, given the current oversupply situation in the global market. An agreement over financing and/or equity participation could unlock a new deal during 2015-2016, but in any case it seems clear that expectations of Russian gas reaching China before 2020 are receding, and could disappear altogether if delays in progress on one or both of the proposed pipelines occur. Indeed, although the initial Power of Siberia deal committed Gazprom to first deliveries in 2019, and the sanctity of contract was confirmed in May $2015,{ }^{123}$ there is a clause in the contract which allows for a two-year delay to 2021 which could easily be triggered if market circumstances do not improve. As a result it would increasingly appear that Gazprom is at the mercy of its Chinese counterparts, who are operating in a buyers' market, have the lure of financing to offer, and have every incentive to adopt a wait and see policy in gas import negotiations. In contrast Gazprom and the Russian authorities appear to be searching for any alternative options that can allow gas exports to progress, without a necessarily coherent plan for implementation (with the new discussion on a Far East pipeline being the latest example of their increasing desperation). As of August 2015 it seems that Power of Siberia is likely to go ahead at some point between 2019 and 2021 , with Altai as a potential second, and later, project, but it is by no means inconceivable that this outlook could change if the market dynamics continue to deteriorate or if the political situation catalyses a change of perspective.

Therefore, although Russia's pivot to Asia was created as a diversification away from western, and particularly European markets, and was even seen in Russian circles as providing the opportunity to threaten European security of supply, in fact it would appear that Gazprom is set to remain as reliant on Europe as ever, especially over the next seven to ten years. Indeed, given the uncertainties surrounding the Chinese and NE Asian gas markets, and the increasing strength of China's position as a major centre of gas demand with the consequent bargaining strength that provides, it would be logical to argue that Russia needs to avoid becoming too reliant on the Chinese market. It is certainly conceivable that as China continues to establish a more market related gas price domestically, it could seek to renegotiate the terms of trade for any or all of its gas import contracts, meaning that exporters such as Gazprom will need to have alternative markets to use as diversification from that risk and also to create some form of bargaining leverage in negotiation with CNPC and other potential Chinese gas importers. Furthermore, the interaction between all the major global gas demand centres is likely to increase as growing LNG supply leads to greater interconnection of prices on a netback basis, with the result that Gazprom's European business will remain vital to its global portfolio and will interact on a price and volume basis with its expanding Asian export business.

\footnotetext{
${ }^{121}$ Interfax, 3 Sept 2015, "Gazprom expecting to sign agreement on purchase, sale of gas along western route to China in spring 2016"

122 Interfax, 3 Sept 2015, "Gazprom, CNPC sign memorandum for pipeline gas deliveries to China from Far East"

123 Interfax, 8 Aug 2015, "Contract of Gazprom, CNPC on Eastern Route came into effect on May 13"
} 

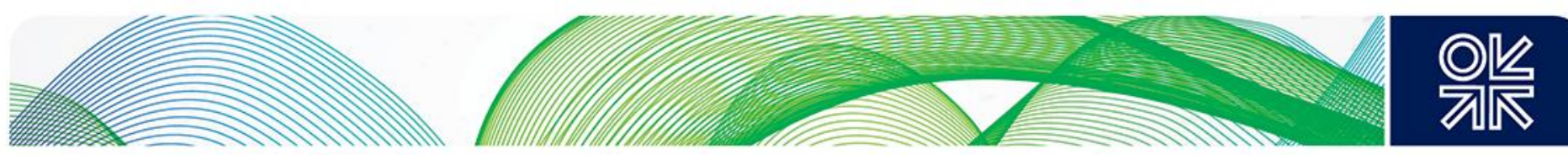

\section{New strategy for Russian gas in the European market: "under construction"}

\section{Soviet and Russian gas in the European market: historical overview}

Russia (and previously the USSR) has been supplying gas to Europe since the late 1960s, when first exports flowed to Austria in $1968 .{ }^{124}$ From this point gas flowed continuously for the rest of the Soviet period, with volumes increasing to over $100 \mathrm{bcma}$ by 1990 . Indeed it is interesting to note, at the current time of heightened political tension in Ukraine, that Soviet gas exports began only months before the USSR invaded Czechoslovakia and continued uninterrupted throughout that period and for the duration of the Cold War. Furthermore the Soviet authorities prioritised the security of export sales to the extent that the domestic population in western Russia and Ukraine frequently had to endure gas shortages in order to ensure sales to the West continued uninterrupted. ${ }^{125}$

From this early beginning Soviet and Russian gas benefitted from the growth in gas demand in Europe, which expanded consistently through the 1970s as far as the mid-2000s as customers across all sectors switched from oil (and in some instances coal) to gas. From a level of just over $100 \mathrm{bcm}$ in 1970, demand in Europe exceeded $570 \mathrm{bcm}$ in 2005 driven by the expansion of gas networks across the continent and in particular by increasing consumption in the power sector, ${ }^{126}$ where the widespread construction of CCGT plants in the 1990s and early 2000s created what became known as the "Dash for Gas" in a number of countries. Over this period Gazprom's exports to Non-FSU countries rose from an initial level of $3.5 \mathrm{bcm}$ in 1970 to a peak of $162 \mathrm{bcm}$ in 2005 , with sales extending across 28 countries in the region (see Figure 13).

An important consequence of the replacement of oil by gas in the energy mix was the creation of a netback market pricing mechanism within a long-term contract structure. This form of pricing and sales reflected the fact that consumers had a real choice between using oil or oil products and gas, and also the fact that suppliers such as Russia were making huge investments in upstream and transportation assets and needed to ensure a multi-year market for their product. The pricing relative to oil ensured that gas would remain competitive with its main energy rival, with a discount normally being ensured under the formulae used in the contracts, while the long-term nature of the deals, which included take-or-pay clauses to ensure that the buyers would take a minimum annual quantity (usually $85 \%$ ) meant that the risk could be spread between supplier (taking the price risk) and buyer (taking the volume risk). ${ }^{127}$

\footnotetext{
124 Hogselius (2013), p.105

125 Hogselius (2013), pp.89-103

${ }^{26}$ IEA Energy database, figures for EU35 in 2005

127 See Stern (2007) and Stern (2009b) for a full discussion of oil-linked gas contracts in Europe.
} 

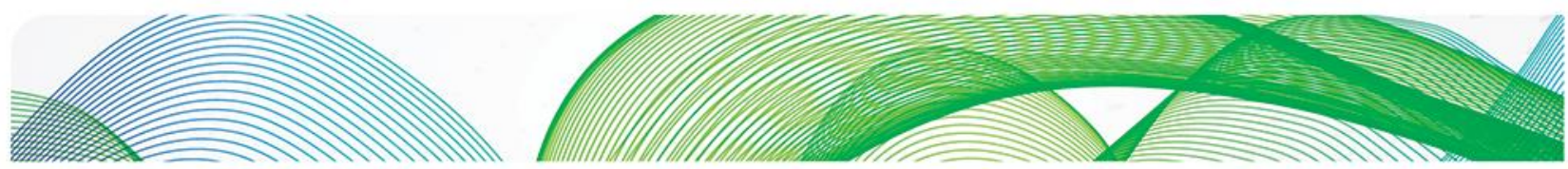

Figure 13: Russia gas exports to Europe by country (1970-2005)

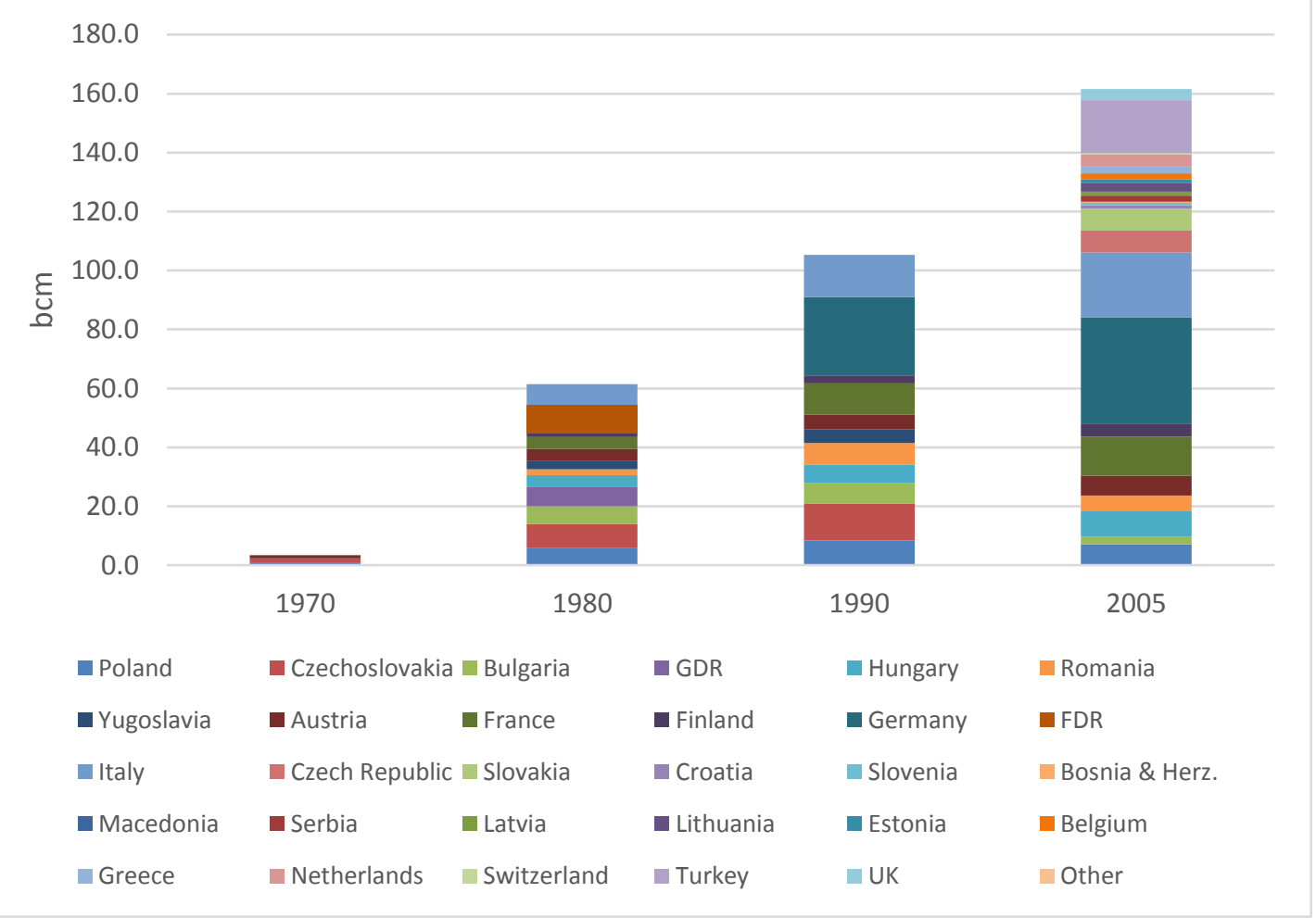

Source: Hogselius (2013), Gazprom Databooks 2008-2014

Over time oil was largely removed from the majority of stationary energy sectors in Europe, with oil product demand being focused on transportation, but despite this the concept of oil-linked gas pricing remained in place due to the familiarity of the concept amongst buyers and sellers, the profits being made from it and the lack of obvious alternatives. Furthermore, the governance structure of the European energy market, which was dominated by monopsony buyers and monopoly sellers of gas, also created a sense of inertia as the dominant utility companies in most European countries could essentially pass through the cost of their purchased gas to end-consumer segments who had very little choice, if any, in their gas supply. As a result, although the link between oil and gas prices was an increasingly irrelevant reflection of supply and demand in the gas market, often causing gas prices to be higher than they might naturally have been, this did not disturb the contractual relationship between suppliers such as Russia and their major utility customers in Europe, as it was the captive end-consumers of these utility companies who ultimately paid the price..$^{128}$

This story of market growth and utility domination finally peaked in 2005, when the "golden age of gas" in Europe arguably came to an end. ${ }^{129}$ By then rates of growth for gas demand in the power sector had started to slow, with the result that overall consumption plateaued and imports of Russian gas stabilised in the range 150-160bcma. ${ }^{130}$ However, with oil prices, and therefore gas prices, rising consistently throughout the period, both suppliers such as Gazprom and the utility company buyers continued to make significant profits from the European gas business. This era of stability was not to last though, as a multiplicity of complex and inter-related factors combined to introduce significant challenges to both European gas demand and to the region's major sources of imported gas.

\footnotetext{
${ }^{128}$ For a full discussion of the governance structure of the European utility market and the interaction with gas suppliers, see Stern and Rogers (2014b)

${ }^{129}$ See Stern J. "Russian responses to commercial change in the European gas market" in Henderson \& Pirani (2014), Ch.3, pp.50-81

${ }_{130}$ Gazprom Databook 2003-2008
} 

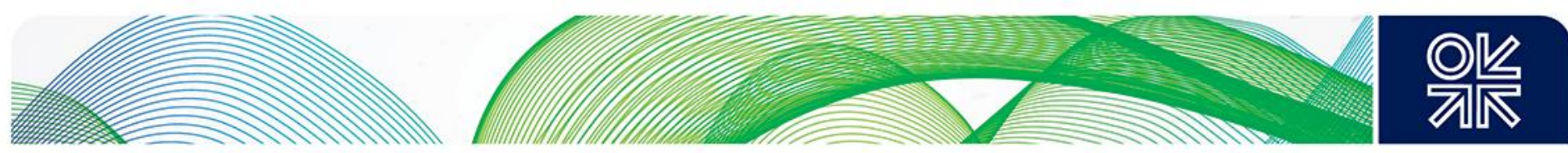

\section{Economic crisis of 2008/09 catalysed significant changes in the functioning of the European gas market}

Primarily, the economic crisis of 2008/09 and its aftermath brought energy demand growth in Europe to a halt, as recession in many countries initiated a period of economic stagnation that has continued into 2015. As a consequence gas demand, which reached $587 \mathrm{bcm}$ in 2008 has been in structural decline since (with the one exception of 2010 when there was a very cold winter), reaching a low of $476 \mathrm{bcm}$ in 2014,131 a situation that was further compounded by the fact that many European countries had over-contracted for gas supply at the same time. ${ }^{132}$ This very sharp decline in gas demand has been exacerbated by the impact of two other energy sector changes. Firstly, an increasing focus on renewable energy sources across Europe has seen gas and other hydrocarbons losing market share in the power sector as various countries across the EU have offered financial support mechanisms to increase the use of solar and wind power in order to meet environmental targets. ${ }^{133}$ Secondly, the specific role of gas in the power sector has been further undermined by the impact of the shale gas revolution in the USA, where the prevalence of cheap gas has frequently driven the Henry Hub price down to levels where gas starts to displace coal in the US power sector. This has freed up a large amount of US coal for export, which has then arrived in Europe at distressed prices and displaced gas under long-term contracts tied to the oil price, which was above $\$ 100 /$ barrel until the end of $2014 .{ }^{134}$

This sharp decline in demand would have been enough to put pressure on gas prices in Europe by itself, but a second impact of the US shale revolution, the redirection towards Europe of LNG, notionally reserved for, but no longer needed by, the US market, led to a sharp decline in spot prices at the major gas hubs in the UK and Continental Europe. ${ }^{135}$ As a result, by mid-2010 a significant disparity had opened up between the hub-based "market" price in Europe and the price for gas sold under long-term oil-linked contracts, with significant implications for European utility companies and for Gazprom. Primarily it meant that the utility companies came under pressure from their customers to reduce gas prices, as the difference between the price that the latter were being forced to pay and the price of gas at the hubs was becoming increasingly obvious. A consequence of this was that Gazprom was put under pressure from its buyers, who wanted not only to reduce volumes down to minimum take-or-pay levels, or even below in some cases, but were also looking to renegotiate price levels and volume flexibility. ${ }^{136}$

\footnotetext{
${ }^{31}$ Data from Honore (2014) and IEA (2015)

132 Melling (2010), p.48

${ }^{133}$ BP Statistical Review of World Energy 2015, see http://www.bp.com/en/global/corporate/about-bp/energyeconomics/statistical-review-of-world-energy/review-by-energy-type/renewable-energy/renewables-in-this-review.html for discussion of impact of renewables

${ }^{134}$ Financial Times, 3 Oct 2012, "US coal exports to Europe soar"

135 Reuters, 24 Mar 2011, "Analysis: Japan fails to divert LNG away from Europe"

136 Fitch Ratings, 9 Nov 2012, "EU utilities may press for more price cuts from Gazprom"
} 

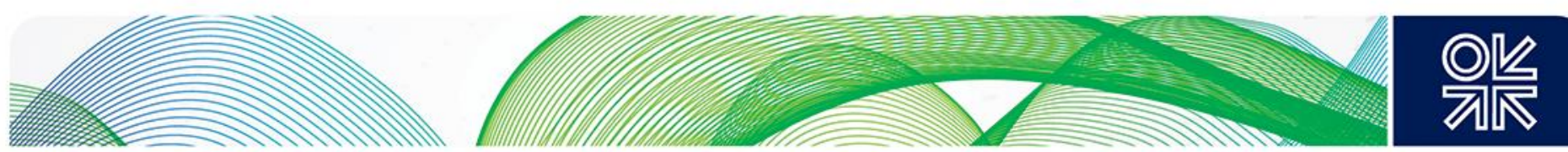

Figure 14: Average Russian gas export price versus UK NBP (2010-2015)

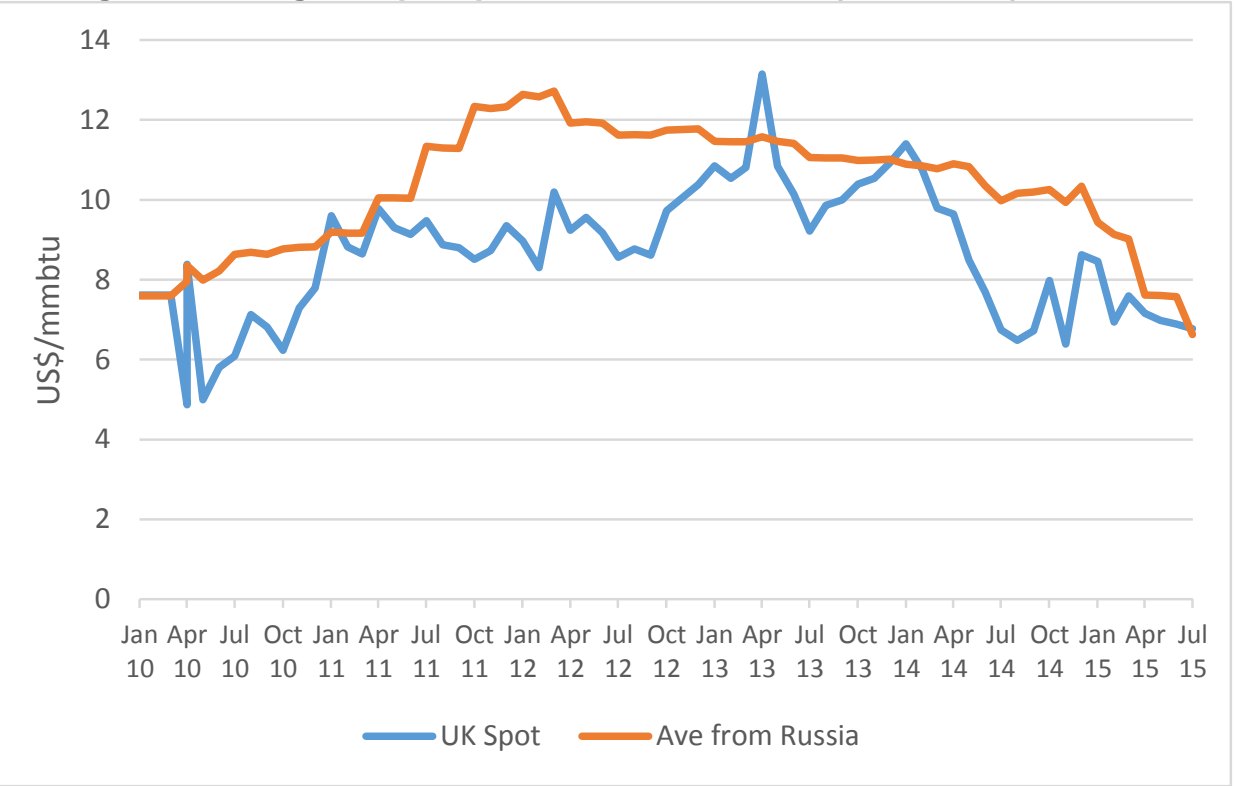

Source: World Gas Intelligence

The ability of European end-consumers of natural gas to put pressure on the utility buyers of Russian gas was enhanced by another dislocation in the European market, created by EU policy on market liberalisation and increased competition in energy markets, which has ultimately been consolidated under the terms of the Third Energy Package. ${ }^{137}$ With third party access to gas pipelines being opened up and the ownership of assets in the gas sector being unbundled, gas buyers were given much greater access to a variety of suppliers, while at the same time the liquidity at gas hubs was improving and an increasing number of producers were starting to sell their gas on a market, rather than an oil-linked, basis. ${ }^{138}$ As a result, gas consumers could start to demand lower prices from utility companies, even if those utilities were set to make a loss on the purchase of gas under long-term contracts that remained linked to the oil price.

\section{Gazprom forced to address price versus volume issue}

For Gazprom, this led to a major change in priority in terms of its European export strategy. Until the mid-2000s the company's main objective had been to ensure that it could produce enough gas to satisfy its customer base across a broad geography stretching from West Siberia through the countries of the Former Soviet Union and into the European continent, and indeed questions had started to be asked about its ability to fulfil its export obligations. ${ }^{139}$ Given the need to ensure supply to European customers, who were effectively contributing the revenues generated by a high gas price which could allow Gazprom to subsidise the low gas prices it was forced to offer domestic customers, ${ }^{140}$ the company embarked on the development of the huge gas resources on the Yamal peninsula, starting with the Bovanenkovskoye field. ${ }^{141}$ However, after 2008 the company was faced with a different dilemma, namely whether to try and maximise price, by maintaining its oil-linked contract strategy, or volume, by offering new lower prices. In effect it has chosen to try and find a mid-

\footnotetext{
137 See Stern, J. in Henderson \& Pirani (2014), Ch.4, pp.83-88

${ }^{138}$ Heather (2012) pp.44-46

139 Stern (2009a), p.2

140 Henderson \& Pirani (2014) pp.117-123

141 See http://www.gazprom.com/about/production/projects/deposits/bm/ for detail, accessed on 12 June 2015
} 

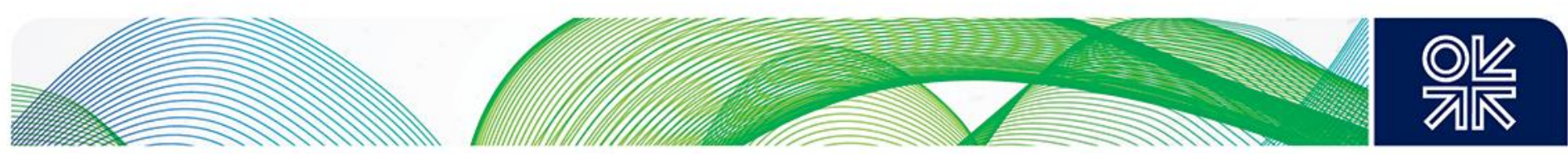

ground between the two, ostensibly asserting the importance of oil-linked prices while adapting to the demands of its customers and market reality.

Primarily, Gazprom's position on oil-linked prices appears to be driven by political will as much as commercial argument, as Russian President Vladimir Putin has endorsed the view that Russia, and other major suppliers, should "continue to support gas pricing based on oil/oil products indexation to ensure fair prices and stable development of natural gas resources." 142 From a more commercial perspective, Gazprom has also argued that long-term oil-linked contracts provide suppliers with security of demand and support the flexibility offered by the take-or-pay arrangements, while also suggesting that oil and gas prices are in any case inextricably linked and that this is merely reflected in the price formation mechanism used in their contracts. ${ }^{143}$ However, despite these arguments being made, it has become clear that the company has been forced to respond to market pressure which has seen some, although not all, of its major competitors switch to a hub-based pricing strategy. ${ }^{144}$

In the first years after the 2008 economic crisis pressure was brought to bear in a series of renegotiations with major European buyers which ultimately led to international arbitration proceedings being launched, first by Italian company Edison in 2010 but then by a series of other utilities including E.ON, Erdgas Salzburg, PGNiG and RWE. ${ }^{145}$ The process of negotiation and court proceedings led to a number of contracts being reset out of court, but others, such as the RWE case, resulted in a change in contract structure which has led not only to reimbursement of some customers, but also to an easing of take-or-pay terms and the introduction of an element of hubbased pricing into many contracts. However, Gazprom made these adjustments to its contracts on the assumption that any changes would be short-lived and that the market would revert to its pre-crisis norms within three years. Further, while the initial changes involved the acceptance that some gas should be priced at hub levels, this was restricted to any purchases above the minimum $85 \%$ take-orpay level, with the bulk of the sales remaining at oil-linked prices. ${ }^{146}$ Nevertheless, this led to a gradual closing of the gap between Gazprom's contract prices and the hub price in 2009-2011, but the premium still remained on average above $20 \%$ and it gradually became clear that the impact of the economic crisis was going to be longer than expected.

Some important caveats do need to be made, though. The first is that all contract terms are highly confidential, and so many of the results of the arbitrations and contract renegotiations have only become public via the press or conference hall conversations. The second is that Gazprom has occasionally offered a different interpretation of the outcomes than its customers, consistently claiming that it has managed to re-affirm the principle of oil-linked pricing. ${ }^{147}$ And the third is that Gazprom clearly has adopted a different pricing strategy in the various gas consuming countries in Europe, according to the energy mix of each. ${ }^{148}$ Nevertheless, it would appear to be the case that, despite its outward statements on the oil-linked methodology Gazprom gradually started to adapt its pricing levels to take account of market factors, as seen in Figure 15.

\footnotetext{
142 Vladimir Putin quoted at Gas Exporting Countries Forum, Moscow, 1 July 2013, in paragraph 5 of the Moscow Declaration of the GECF, The Second Gas summit of the Heads of State and Government of GECF countries.

143 Stern \& Rogers (2013), p.7

144 Financial Times, 19 Nov 2013, "Statoil breaks oil-linked gas pricing"

145 Stern J. in Henderson and Pirani (2014), Chapter 3, pp.50-81

146 Stern, J. in Henderson \& Pirani (2014), p.63

147 GazpromExport Press Release, 28 June 2013, "GazpromExport on arbitration ruling on price review with RWE Supply and Trading CZ"

${ }^{148}$ Wall street Journal, 22 April 2015, "EU files formal charges against Gazprom for abuse of dominant position"
} 

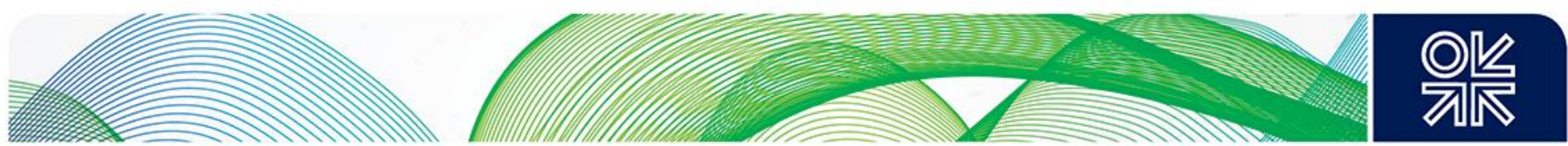

Figure 15: Gazprom's average gas sales price in Europe compared to NBP

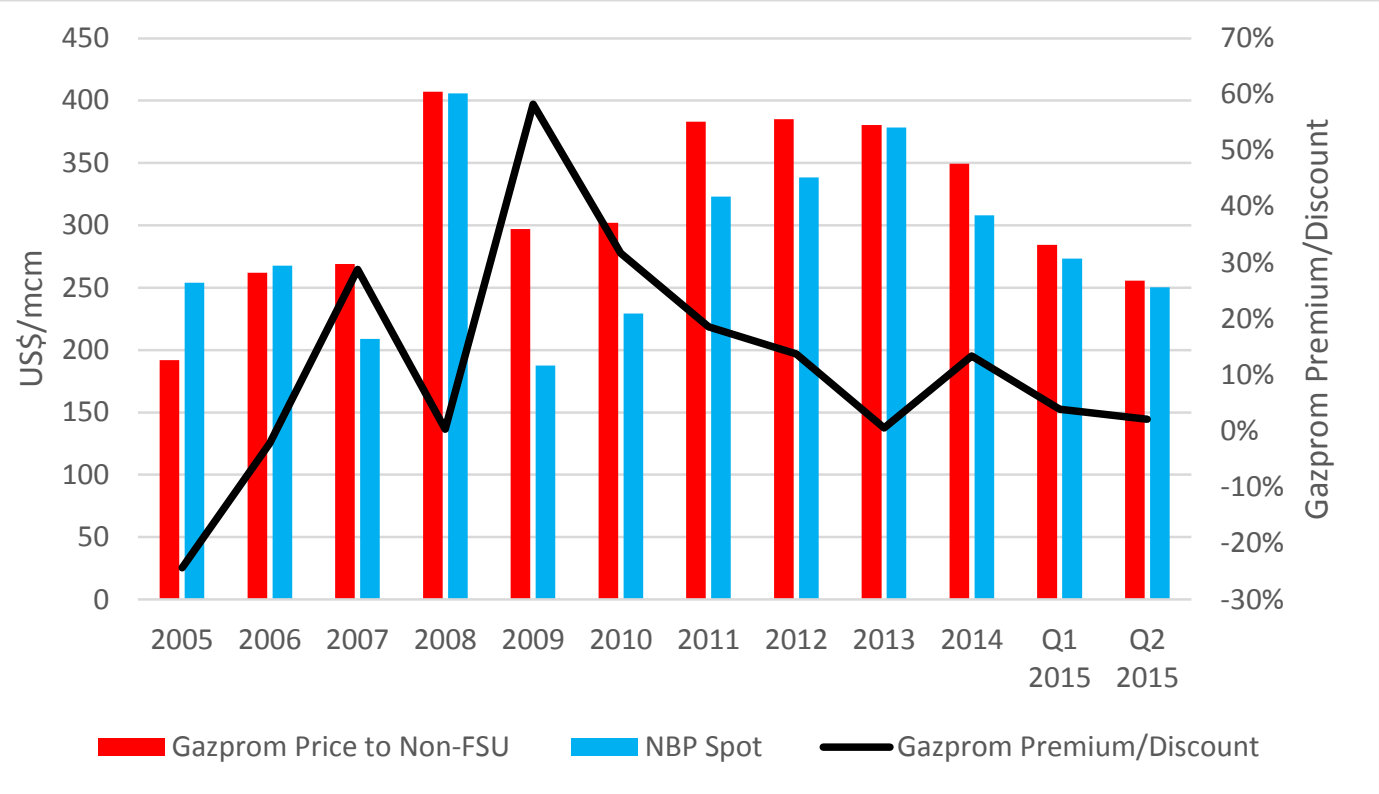

Source: Gazprom Management Discussion and Analysis reports, World Gas Intelligence

However, the persistence of economic problems in Europe and the continuing gap between spot and contract prices meant that Gazprom's gas remained an expensive product, with customers continuing to demand a more competitive price level. As a result, from 2012 further changes were introduced, involving a reduction in the base price (or $\mathrm{P}_{0}$ ) in some contracts by an estimated $7-13 \%$, the reduction in the minimum take-or-pay level to $70 \%$ and the introduction of a rebate system whereby buyers would be compensated for any major difference between the European hub price and Gazprom's contract price. ${ }^{149}$ As a result, Gazprom's average price to its European customers was at parity with the UK spot price in 2013 and also in the first half of 2015, with the premium in 2014 being much lower than the historical post-crisis average (and indeed it may be reduced to zero retorspectively if a rebate, which is currently under negotiation, is ultimately paid to customers).

However, as can be seen from the graph, the reduction of the Gazprom premium has not just been a function of reduced Russian prices but has also been caused by fluctuations in the spot price. Indeed, as Gazprom has often pointed out, a number of unexpected events have impacted the market, most particularly the Fukushima disaster in Japan in 2011 which caused a rapid tightening of the market in Europe as LNG was diverted east to compensate for the shut-down of the Japanese nuclear power sector. Winter weather, whether mild or cold, clearly also plays a major role, but nevertheless it is still apparent that Gazprom has shown an ability to adapt to changing circumstances despite clinging to its overall oil-linked principle.

Another important historical issue, noted above, is that Gazprom has priced its gas according to individual market conditions, creating apparent anomalies in prices across Europe. Figure 16 below shows the prices paid by 23 different countries for Russian gas in 2013, split into regions by colour (West Europe - blue; Central Europe - green; South and South-East Europe - orange; FSU - red). Two main points are worth noting. The first is that distance from Russia, which one might expect to play some part in the pricing decision (with countries further away from Russia paying a higher price for a longer transport distance), seems to have no relation to end price. On average countries in South-East Europe and Central Europe pay more than countries in Western Europe. Furthermore,

\footnotetext{
${ }^{149}$ If the contract price exceeded the hub price by more than a certain amount, believed to be in the range 5-15\%, then Gazprom would refund the difference at the end of the period
} 

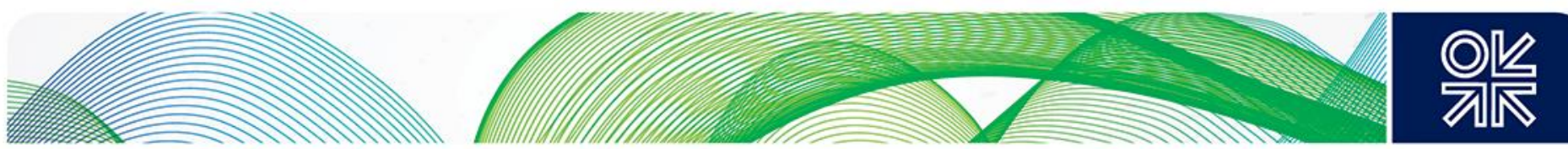

even within regions there are wide price discrepancies, between, for example, Holland and Denmark, Germany and Poland, Turkey and Macedonia. These differences would clearly suggest that Gazprom has exploited its position as a "discriminating monopolist" to extract the maximum value from each market where it sells its product, essentially pricing its gas relative to the alternative fuel in each case (and arguably in line with best business school practice).

Figure 16: Gazprom prices to Europe by country (2013)

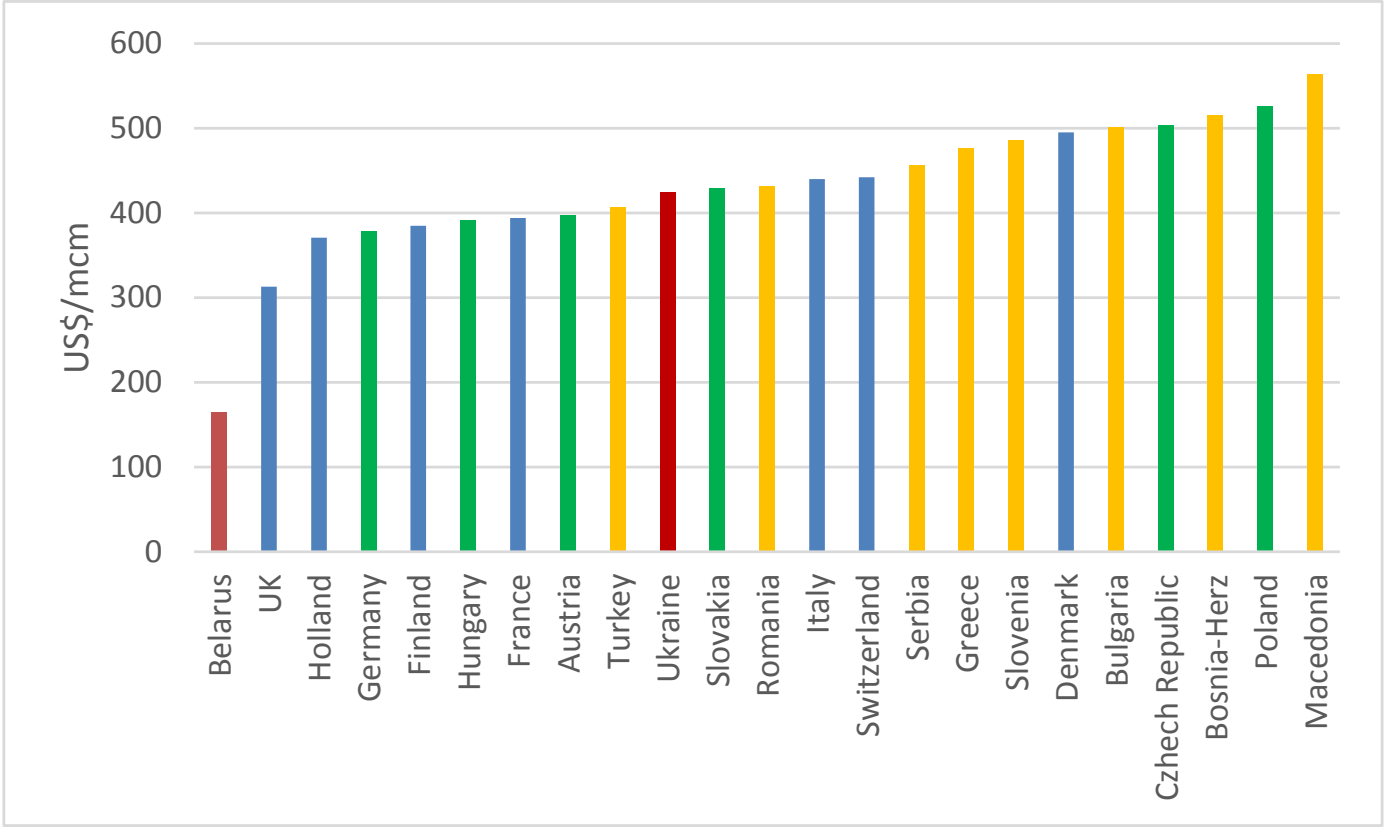

Source: Izvestia, Gazprom

NB: Blue countries are Western Europe, Green are Central Europe, Yellow are South and South-East Europe and Red are FSU

As a result, Gazprom's overall export strategy to date can be summarised as the maximisation of short-term revenue, ${ }^{150}$ establishing a foundation of oil-linked long-term contracts and adapting it in an ad hoc fashion to suit individual markets in Europe according to their ability to access alternative sources of supply and alternative price benchmarks. As can be seen from Figure 17 below, the company has been relatively successful in achieving its goal, with revenues rising consistently to 2008, before reversing in the aftermath of the economic crisis but then recovering to 2008 levels by 2013. The decline in 2014 may, however, mark the start of a new more difficult period for the company in Europe, but before discussing that we should address the legislative and political pressure that is also being put on the company by the EU.

\footnotetext{
${ }^{150}$ Alexander Medvedev, quoted on Gazprom web-site, 26 April 2011, "Alexander Medvedev: Profit is our Priority" at http://www.gazprom.com/press/reports/2011/main-profit/, accessed on 12 June 2015
} 

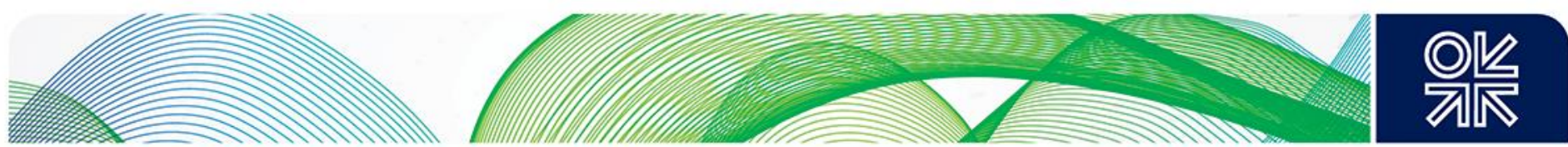

Figure 17: Gazprom revenues from Non-FSU countries

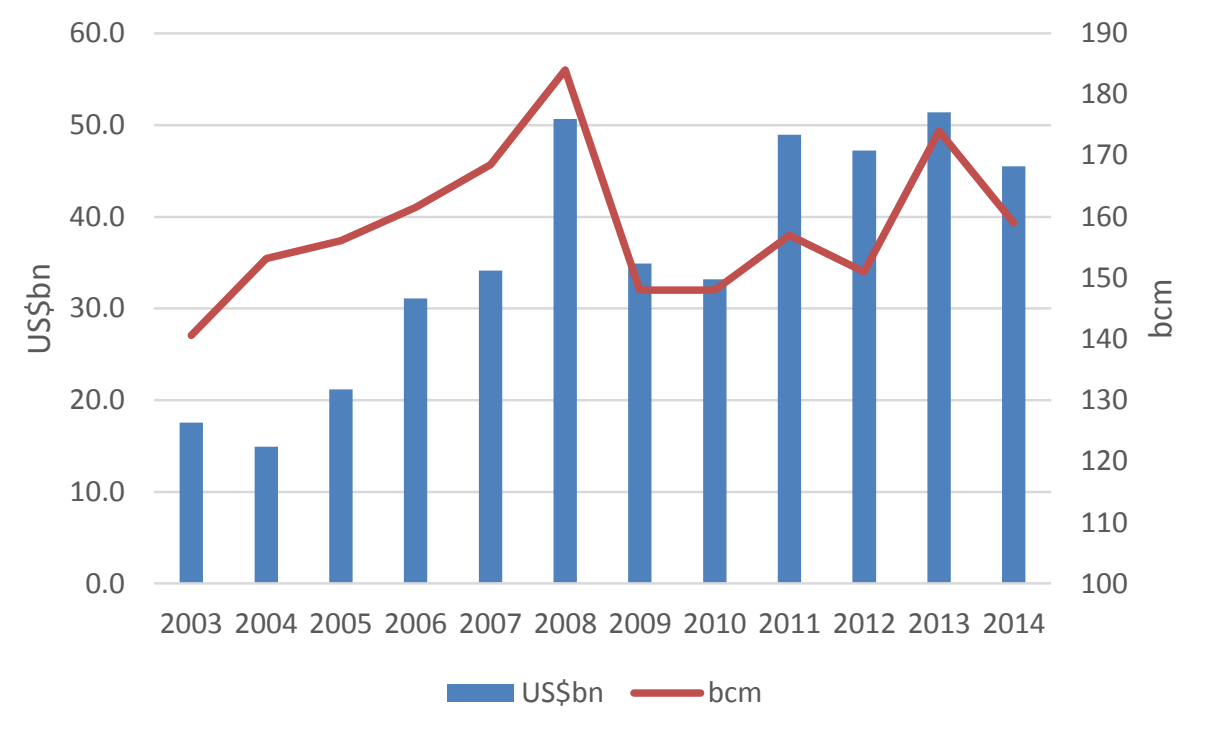

Source: Gazprom IFRS Financial Statements, 2003-2014

\section{The impact of EU legislation}

EU intervention with regard to Russia has been driven by two key motivations, which have overlapped to an extent as they have been developed into legislation and policy. The first has been the economic desire to create a more liberalised gas market where dominant suppliers such as Gazprom are forced to compete, while the second is a political desire to allow and encourage European consumers (especially those in countries largely or wholly dependent on Russian gas) to diversify away from Gazprom's exports, which are seen as a security risk in the light of the current Ukraine crisis. The steps taken by the EU to achieve these goals have been varied, and have certainly not always been directly targeted at Gazprom and Russia, but nevertheless they have changed both the way in which Russian gas can be sold into Europe and also the vision which Gazprom has for its future in the European gas market.

As mentioned above, the primary driver of change has been the Third Energy Package (TEP), the impact of which has been described in detail by Yafimava (2013). The deregulation of the gas market will obviously impact all the participants, but Gazprom is particularly affected because it is the largest supplier and its gas crosses many transit countries to reach its customers. This is important because under the new rules gas now has to pass through hubs in Europe, using back-to-back transport deals to move the gas from hub to hub and ultimately to the end consumer. As a result, while in the past Gazprom would negotiate transport contracts across countries that would uniquely allocate pipeline capacity to its gas, under the new rules all pipes must offer third party access and capacity must be auctioned on a regular basis. This means that the potential for a mismatch between Gazprom's longterm supply contracts and its transport needs has emerged, as although its existing contracts have been exempted from the TEP, when they expire (which is set to happen at different times for transport and supply) Gazprom must then comply with the new rules.

As a result, Gazprom was already facing increased complexity in dealing with the European market before the EU took another more specific step related to the variable pricing discussed above. Following a complaint from Lithuania, in 2012 the Competition Authority of the EU (DG COMP) opened proceedings against Gazprom alleging malpractice in a number of countries in Central and 

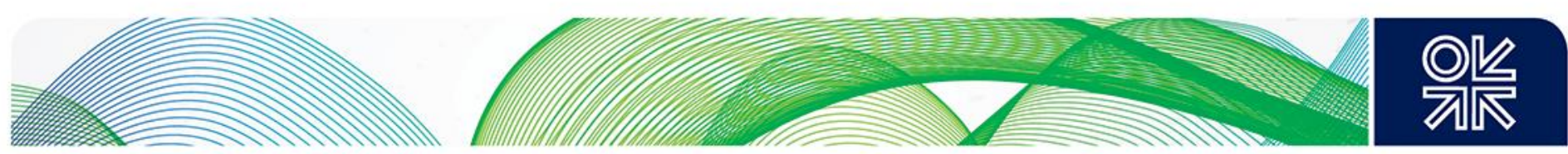

Eastern Europe. ${ }^{151}$ In April 2015 DG COMP reached its initial conclusions on the case, asserting that in eight countries Gazprom hindered competition by preventing cross-border selling, in five it then used this situation to charge excessively high prices at oil-linked rates, while in two countries it used gas prices as leverage to secure favourable pipeline deals. ${ }^{152}$ Gazprom has until September 28th 2015 to respond to these claims, a number of which have already been resolved, ${ }^{153}$ but nevertheless the EU has sent a clear message that the company's business methodology in Europe needs to change.

\section{Europe's need for Russian Gas}

However, despite the clear pressure on Gazprom to respond to regulatory changes in Europe and to adapt to changing customer demands on price formation and price levels, the company remains confident that its gas will continue to be needed in the West, and its senior management consistently make statements to this effect. ${ }^{154} \mathrm{~A}$ key element in understanding the impact of Gazprom's changing export strategy, then, is an assessment of whether this confidence is well-placed or a significant strategic mistake. Figure 18 below shows a graphic analysis of Europe's gas supply and demand balance to 2030,155 and emphasizes the fact that the region's import requirement is set to rise significantly. Based on a forecast by Honore (2014), which she has adjusted to take actual data from 2014 into account, demand in Europe is set to rebound gradually from its 2014 low of $476 \mathrm{bcm}$ to reach $594 \mathrm{bcm}$ by 2030 , assuming average weather patterns over that time (in contrast to 2014 which saw an unseasonably warm winter). In contrast, European gas supply is set to continue the decline which has been on-going since the start of this century. Production on the UKCS has been in rapid decline since 2000, and although the rate has slowed it seems inevitable that it will continue. ${ }^{156}$ Meanwhile production in the Netherlands has been hit by problems at the Groningen field, where a series of seismic events has led to restrictions on output. ${ }^{157}$ Norway, regarded here as indigenous production, appears to have peaked in 2012 at $115 \mathrm{bcm}$, and although no rapid fall is expected output is likely to stay in a $100-105 \mathrm{bcm}$ range to 2020 before gradually declining thereafter. One bright spot could be the development of European shale gas, ${ }^{158}$ and despite the current reluctance of many countries to endorse fraccing we have assumed some small growth from 2020 to reach a (perhaps optimistic) production level of $20 \mathrm{bcm}$ of output by 2030. As a result overall European gas output is expected to slip from around $250 \mathrm{bcm}$ in 2014 to $225 \mathrm{bcm}$ in 2020 and $150 \mathrm{bcm}$ in 2030, leaving an import gap of over $310 \mathrm{bcm}$ by the end of this decade and over $420 \mathrm{bcm}$ by 2030 .

\footnotetext{
${ }^{151}$ European Commission Press Release, 4 Sept 2012, "Antitrust: Commission opens proceedings against Gazprom"

152 See EU Statement of Objections at http://europa.eu/rapid/press-release IP-15-4828 en.htm, accessed on 12 June 2015

153 Interfax, 4 Sept 2015, "Gazprom to present written response to antitrust claims to EC Sept 28"

${ }^{154}$ For example Alexei Miller speech at the Conference "Europe and Eurasia: Towards the New Model of Energy Security", 13 April 2015, at http://www.gazprom.com/press/miller-journal/029076/, accessed on 25 Aug 2015

55 Europe is defined according to Honore (2014), meaning the 28 countries of the EU plus Albania, Bosnia \& Herzegovina, Macedonia, Norway, Serbia, Switzerland and Turkey

${ }^{156}$ Financial Times, 28 May 2014, "The North Sea's decline is a problem for the whole of the UK"

${ }^{157}$ New York Times, 4 June 2014, "A gas cache, now under shaky ground"

158 Ernst \& Young, "Shale gas in Europe: revolution or evolution?" at

http://www.ey.com/Publication/vwLUAssets/Shale gas in Europe revolution or evolution/\$File/EY-Shale gas in Europerevolution or evolution.pdf, accessed on 26 June 2015
} 

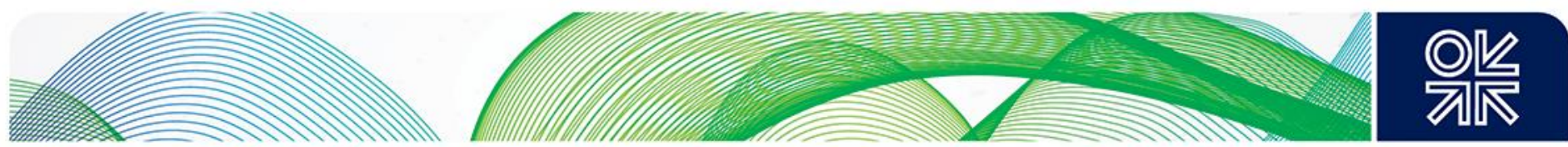

Figure 18: European gas supply and demand estimate

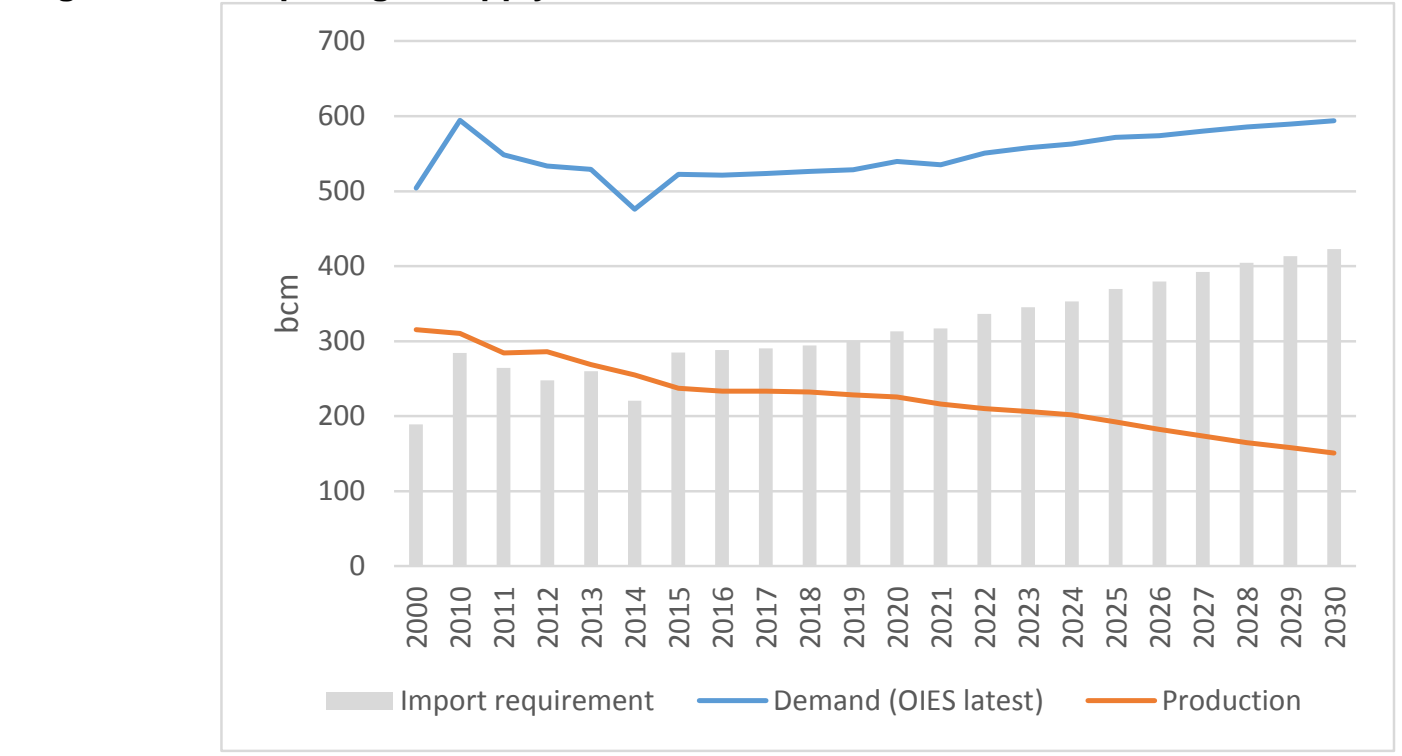

Source: Honore (2014) and Authors' calculations

As the picture of an increasing import requirement continues to develop, Gazprom's confidence in the need for its gas in Europe has been further boosted by the growing perception that alternative sources of pipeline gas from traditional and new sources may be in short supply. This issue has been analysed in depth by Stern et al (2014), but their analysis can be summarised briefly as follows. Flows of North African gas, which have supplied Europe for many years, have been undermined by the political turmoil in the region as well as rising domestic demand that has been encouraged by subsidised prices. Although the three main exporting countries, Algeria, Libya and Egypt, hold combined proved reserves of $7.8 \mathrm{tcm}$, the difficulties associated with attracting finance in a worsening investment climate and reducing local consumption will continue to undermine exports to Europe. Algerian production peaked in 2008 at $86 \mathrm{bcm}$, and despite a government target of $100 \mathrm{bcm}$ by 2015 , a series of project delays combined with increasing bureaucracy and political problems mean that this level is unlikely to be reached in the near future. There is some hope for a medium term rebound if the political and business environment improves, which could see exports also increase (see Table 4 below), with the potential for growth in pipeline sales (which land in Italy and Spain) and LNG exports (mainly directed to Europe but obviously available to the global LNG market). A major caveat remains the level of domestic demand (bolstered by low regulated prices), though, which is also forecast to grow and could mean that gas exports in 2030 are barely higher than in 2013. ${ }^{159}$

Libya and Egypt have even bigger problems, having been impacted by a number of years of political turmoil that have undermined their hydrocarbons production. Egypt has also been particularly affected by the rise in its domestic gas consumption, and in 2014/15 the Energy Ministry has even suggested that gas output may be below the level of internal demand, meaning that the country could be a net gas importer for the first time. ${ }^{160}$ Although a number of new gas field developments are planned, and ENI has in September 2015 made a giant new gas discovery off the Egyptian coast, ${ }^{161}$ it appears unlikely that they will be sufficient to make Egypt a gas exporter again in the foreseeable future, and its LNG facilities are set to remain idle unless a third party (perhaps Israel - see below) contracts to use them. ${ }^{162}$ Pipeline gas exports from Libya have continued, although at a level around half of the

\footnotetext{
159 Stern et al (2014), pp.19-20

${ }^{160}$ Middle East Economic Survey, 57:6, 7 Feb 2014, "Egypt heads for gas deficit”; Reuters, 21 May 2015 , “Egypt permits private sector to import natural gas"

${ }^{161}$ Wall Street Journal, 31 Aug 2015, "ENI reports huge natural gas discovery off Egyptian coast"

162 Financial Times, 27 Jan 2014, "BG Group shares tumble after warning on Egypt production"
} 

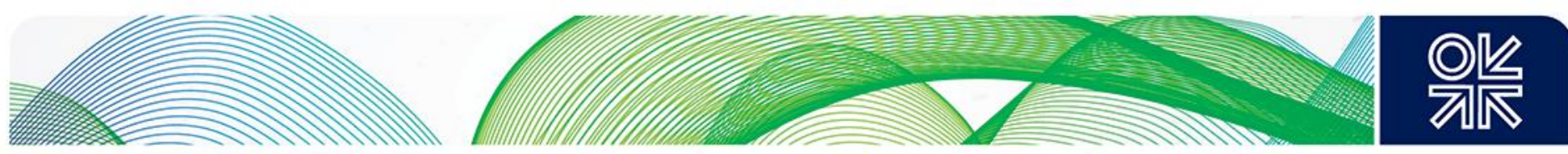

country's $11 \mathrm{bcm}$ export capacity. The future is difficult to predict, given the disarray being caused by the political turbulence in the country, but on the assumption that this ultimately abates the possibility exists for a recovery in sales to Europe towards $11-15 \mathrm{bcm}$, as the country certainly has the reserve capacity to meet the required level of production. ${ }^{163}$

Two other potential sources of gas from the south also deserve to be mentioned. The East Mediterranean has seen a number of gas discoveries made over the past few years, with the Leviathan field offshore Israel and the Aphrodite field in Cypriot waters offering the potential to supply domestic and export markets. However, plans for LNG exports from Cyprus have been hit by disappointing drilling results which mean that production in not expected in the near future, ${ }^{164}$ as well as political issues with Turkey. Israel's prospects look more promising, although it seems that its gas will initially be focussed on regional markets rather than Europe. A number of solutions have been suggested, including use of Egypt's LNG facilities, pipeline exports to neighbouring countries and also a pipeline to Turkey, although all of these are subject to significant political risk. ${ }^{165}$ Nevertheless in Table 4 we have assumed that pipeline sales to Europe will have commenced by the end of the next decade.

The most important new source of gas pipeline imports to Europe, though, will be Azerbaijan, which already exports gas to Turkey but is set to send its gas into the heartland of the European continent thanks to the development of the second phase of the Shah Deniz field and the construction of the TANAP and TAP pipelines across Turkey and into southern Europe. ${ }^{166}$ However, although export volumes are set to expand sharply by the end of this decade, reaching $23 \mathrm{bcm}$ by 2020 from their current level of $6 \mathrm{bcm}$, a recent study by Ryazeva (2015) has suggested that further upside from here is limited by a lack of new gas development options, meaning that sales are only likely to reach a maximum of $27 \mathrm{bcma}$ by $2030 .{ }^{167}$ Other potential sources that have been identified to satisfy European demand through the "Southern Corridor" via Turkey include Iran and Northern Iraq. However, it now seems likely that the former will focus on markets much closer to home in the Middle East and SE Asia rather than trying to compete in Europe, ${ }^{168}$ while the latter will clearly depend upon a much improved political situation and both are unlikely to have any material impact before 2030. ${ }^{169}$

Table 4: Estimating Europe's gas import requirement to $2030(\mathrm{bcm})$ and potential sources of gas supplies

\begin{tabular}{|l|rrrr|}
\hline & $\mathbf{2 0 1 3}$ & $\mathbf{2 0 1 5}$ & $\mathbf{2 0 2 0}$ & $\mathbf{2 0 3 0}$ \\
\hline $\begin{array}{l}\text { Europe Demand } \\
\text { Indigenous Supply }\end{array}$ & $\mathbf{5 2 9}$ & $\mathbf{5 2 2}$ & $\mathbf{5 4 0}$ & $\mathbf{5 9 4}$ \\
Conventional & & & & \\
Shale & 269 & 237 & 225 & 151 \\
European Import Requirements & & & 1 & 20 \\
Non-Russian Pipeline Imports & $\mathbf{2 6 0}$ & $\mathbf{2 8 5}$ & $\mathbf{3 1 3}$ & $\mathbf{4 2 3}$ \\
Algeria & & & & \\
Libya & & & & \\
Egypt & 25 & 28 & 20 & 22 \\
Azerbaijan & 11 & 8 & 10 & 15 \\
Israel & 0 & 0 & 0 & 0 \\
Northern Iraq & 6 & 6 & 23 & 27 \\
Gap for Russia and LNG & 0 & 0 & 0 & 10 \\
\hline
\end{tabular}

Source: Honore (2014), Stern et al (2014), Author's calculations

\footnotetext{
${ }^{163}$ Stern et al (2014) p.21

164 Natural Gas Europe, 23 Jan 2015, "Cyprus moves onto the next drilling"

165 Financial Times, 6 Nov 2013, "Israel set to become major gas exporter"

${ }^{166}$ Financial Times, 1 Jan 2014, "Azerbaijan gas pipeline aims to carve out a niche across Europe"

167 Ryazeva (2015), p.58-59

168 Interfax, 8 June 2015, "Iranian demand no barrier to exports - NIGC exec"

169 Interfax, 15 June 2015, "Solving Kurdistan's gas riddle"
} 

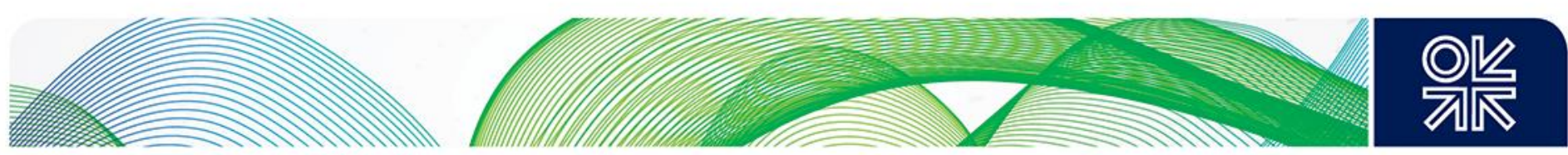

The overall supply and demand for gas in Europe, based on the assumptions discussed above, is shown in Table 4 and confirms Gazprom's confidence that the continent's import requirement is set to grow sharply even with nearly flat demand dynamics. At a recent press conference ahead of the June 2015 AGM, Gazprom's Deputy Chairman of the Management Committee Alexander Medvedev estimated that Europe would require an extra $211 \mathrm{bcm}$ of imports by $2035,{ }^{170}$ and the analysis above, which sees an extra $163 \mathrm{bcm}$ needed by 2030 , compared with 2013 , would seem to support this trend. Table 4 also details the pipeline imports that are estimated to arrive from non-Russian sources, which has either been contracted already or which we assume will be prioritised by European countries as they seek to diversify away from Russian gas where possible. Given the assessments for North African, East Mediterranean and Southern Corridor gas outlined above, it is not surprising that there is a significant remaining gap for a combination of LNG and Russian pipeline gas to be imported into Europe.

Table 5 below takes the analysis one stage further and assesses the impact of Gazprom maintaining its share of sales to Europe at the levels seen in 2014, when it accounted for just over $30 \%$ of total demand and $60 \%$ of total gas imports. Indeed the company's stated strategy is to maintain its market share at $30 \%$ of demand out to 2030,171 and the impact of it meeting this goal is shown in the first scenario for Russian exports. Given that European gas demand in 2015 is expected to be lower than in 2013 Gazprom's export volumes can also be expected to fall slightly, and thereafter they would only grow slowly given the modest levels of demand growth which are expected. As a result, Gazprom's volumes would increase by $20 \mathrm{bcma}$ between 2015 and 2030, leaving the remainder to be filled by LNG imports. Table 5 shows some assumptions for LNG from North Africa and the East Mediterranean, which could be expected to have the European market as their target, while the remainder would be sourced from the global marketplace. At present total LNG regasification capacity in Europe is approximately $200 \mathrm{bcma}$, and so the total of $153 \mathrm{bcma}$ of LNG imports by 2030 shown in Table 5 would certainly be manageable.

A possible, and more positive, alternative scenario for Russian exports to Europe could be one in which Gazprom maintains its share of imports at the 2014 level of $60 \%$, which would imply a much faster growth in export volumes to just below $190 \mathrm{bcm}$ by 2020 and to over $250 \mathrm{bcm}$ by 2030 . The obvious corollary to this would be a reduction in LNG imports over the same period, with less than half Europe's regasification capacity being used throughout the period and with a minimal gap for imports apart from North Africa and the East Mediterranean. It would also imply an increase in Gazprom's share of European demand from $30 \%$ to $43 \%$ over the next fifteen years, which would be a very controversial political outcome, and as such is unlikely to occur unless the company, encouraged by the Kremlin, decides to take a much more competitive position on pricing. However, the current Gazprom strategy suggests that this is a much less probable outcome and we would very much regard it as a maximum possible level.

\footnotetext{
${ }^{170}$ Gazprom Press Conference "Gas Export and Enhancing Reliability of Gas Supply to Europe", 9 June 2015, slide 2, available at http://www.gazprom.com/press/conference/2015/export-to-europe/, accessed on 16 June 2015

Gazprom Investor Day 2015, Feb 2015 in Hong Kong and Singapore, slide 11
} 

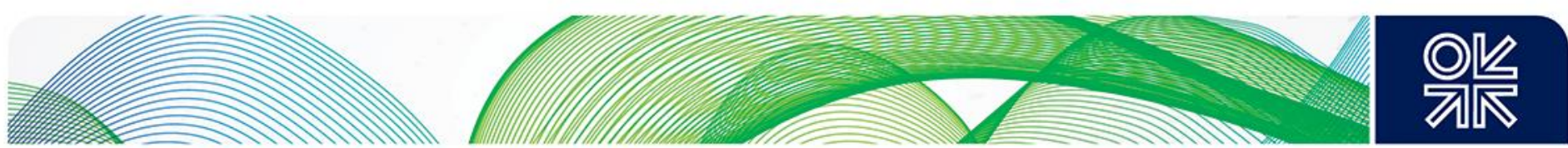

Table 5: Analysis of potential Russian gas exports to Europe (bcm)

\begin{tabular}{|c|c|c|c|c|}
\hline & 2013 & 2015 & 2020 & 2030 \\
\hline $\begin{array}{l}\text { Gap for Russia and LNG } \\
\text { Of which }\end{array}$ & 218 & 243 & 260 & 339 \\
\hline North Africa LNG & 13 & 16 & 21 & 47 \\
\hline Eas Med LNG & 0 & 0 & 6 & 8 \\
\hline Russia & 159 & & & \\
\hline Other LNG & 46 & & & \\
\hline \multicolumn{5}{|c|}{ Outcome 1: Russian gas is $30 \%$ of European Demand } \\
\hline Russia 30\% Demand & & 157 & 162 & 178 \\
\hline Implied Other LNG & & 71 & 71 & 106 \\
\hline Implied Total LNG & & 87 & 98 & 161 \\
\hline Implied Russia \% Imports & & $55 \%$ & $52 \%$ & $42 \%$ \\
\hline \multicolumn{5}{|c|}{ Outcome 2: Russian gas is $60 \%$ of European Imports } \\
\hline Russia $60 \%$ Imports & & 171 & 188 & 254 \\
\hline Implied Other LNG & & 56 & 45 & 30 \\
\hline Implied Total LNG & & 72 & 72 & 85 \\
\hline Implied Russia \% Demand & & $33 \%$ & $35 \%$ & $43 \%$ \\
\hline
\end{tabular}

Source: Gazprom, Authors' Analysis

\section{Gazprom's long-term contracts underpin confidence in European future}

Gazprom's confidence that it can at least maintain its position in Europe is underpinned to 2020 by its current portfolio of long-term contracts, under which the annual contract quantity is $190 \mathrm{bcm}$ in 2015 , falling to $174 \mathrm{bcm}$ in 2020 , meaning that for the next five years it could see exports increase sharply if its customers were to nominate their full amount each year. ${ }^{172}$ As discussed earlier, though, the past five years have seen renegotiations of almost all of Gazprom's European contracts, with the take-orpay level (the minimum annual purchase under each contract) reduced to an estimated average level of $70 \%$. Nevertheless, even under this more conservative measure Gazprom would sell a minimum of $133 \mathrm{bcm}$ in 2015 and 122bcm in 2020 (see Figure 19).

Figure 19: Volume of Gazprom's long-term contracts (LTCs) to Europe

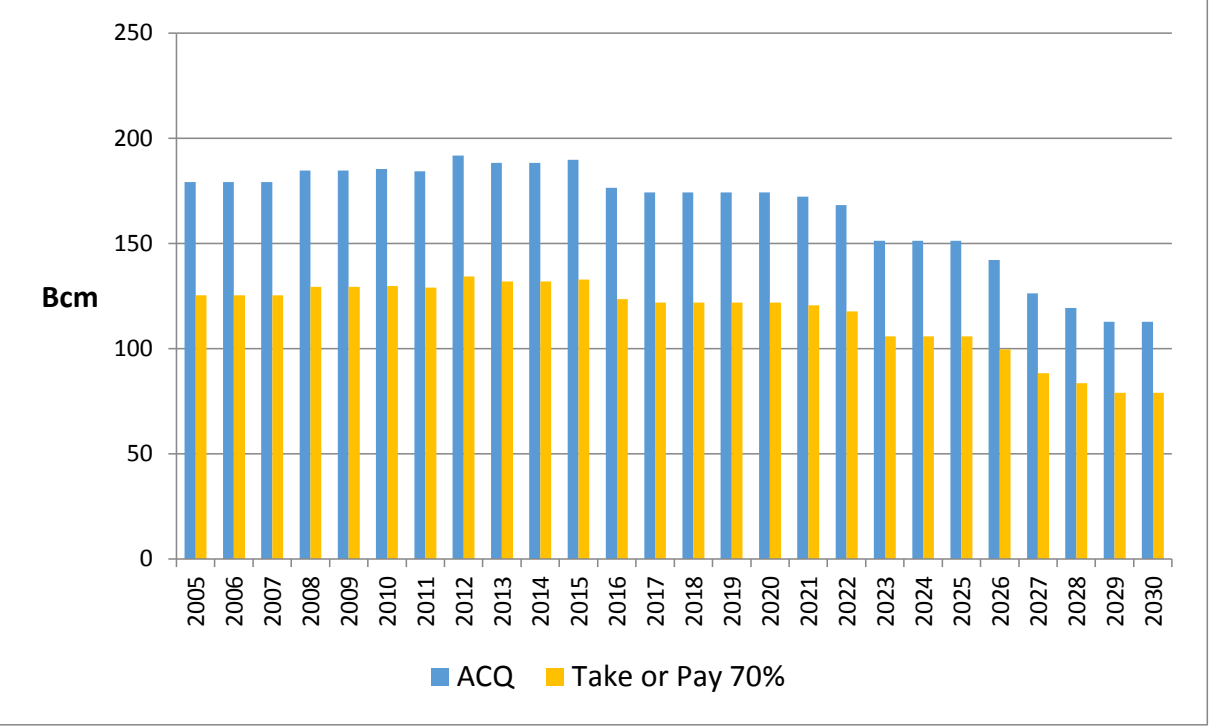

Source: Nexant Energy Database

172 Nexant Energy Database

September 2015: The Political and Commercial Dynamics of Russia's Gas Export Strategy 

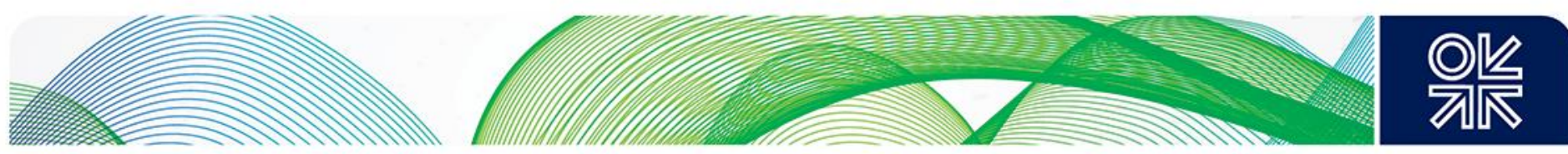

Of more concern to Gazprom on a contractual basis, though, is the period beyond 2020 when its LTCs begin to expire more rapidly. Volumes could drop to $113 \mathrm{bcm}$ on an ACQ basis and to less than $80 \mathrm{bcm}$ on a take-or-pay basis by 2030 if the contracts are allowed to expire without any renewal, meaning a possible halving from current levels. The implications for Europe are shown in Table 6, where two further possible outcomes ( $3 a$ and $3 b$ ) highlight the increase in LNG imports that would be required in Europe should the Russian contracts just run to expiry. Potential outcome 3a (Russian contracts at ACQ) sees total LNG imports of $226 \mathrm{bcm}$ by 2030 while potential outcome $3 \mathrm{~b}$ (Russian contracts at $70 \%$ ToP and no contract extensions) results in $260 \mathrm{bcm}$ of LNG needing to arrive in Europe. Both these estimates exceed the current capacity to regasify LNG on the continent, but it is certainly not inconceivable that sufficient terminals could be built over the next decade and a half if Europe does decide to take an aggressive stance on switching away from Russian gas towards LNG. Indeed in its latest Medium Term Gas Report the IEA already sees an increase to $221 \mathrm{bcm}$ of import capacity from terminals currently under construction. ${ }^{173}$ The two possible outcome would certainly reduce the impact of Russian gas, with $3 a$ leading to Gazprom's share of European demand falling to $19 \%$ by 2030 and $3 b$ seeing it decline to $13 \%$.

Table 6: Russian exports assuming expiry of long-term contracts at ACQ and $70 \%$ ToP (bcm)

\begin{tabular}{|c|c|c|c|c|}
\hline & 2013 & 2015 & 2020 & 2030 \\
\hline Europe Demand & 529 & 522 & 540 & 594 \\
\hline Europe Import Requirement & 260 & 285 & 313 & 423 \\
\hline Gap for Russian Gas and LNG & 218 & 243 & 260 & 339 \\
\hline \multicolumn{5}{|c|}{ Outcome 3a: Russian contracts run down at $A C Q$} \\
\hline Russia & & 190 & 174 & 113 \\
\hline Implied Other LNG & & 37 & 59 & 171 \\
\hline Implied Total LNG & & 53 & 86 & 226 \\
\hline Implied Russia \% Imports & & $67 \%$ & $56 \%$ & $27 \%$ \\
\hline Implied Russia \% Demand & & $36 \%$ & $32 \%$ & $19 \%$ \\
\hline \multicolumn{5}{|c|}{ Outcome $3 b$ : Russia contracts run down at $70 \%$ ToP } \\
\hline Russia & & 133 & 122 & 79 \\
\hline Implied Other LNG & & 94 & 111 & 205 \\
\hline Implied Total LNG & & 110 & 138 & 260 \\
\hline Implied Russia \% Imports & & $47 \%$ & $39 \%$ & $19 \%$ \\
\hline Implied Russia \% Demand & & $25 \%$ & $23 \%$ & $13 \%$ \\
\hline
\end{tabular}

Source: Nexant Energy, Authors' calculations

The potential outcomes of this analysis for Russia and Gazprom can be summarised in Figure 20, which shows an upside case where Gazprom accounts for $60 \%$ of European imports, a middle case where it accounts for $30 \%$ of total gas demand and a downside case where its contracts run to expiry at a 70\% ToP level with no new contracts or contract prolongation. The difference between the high and low cases in 2030 is stark, at $175 \mathrm{bcm}$, while even the gap between the low and middle cases is a significant $100 \mathrm{bcm}$. 

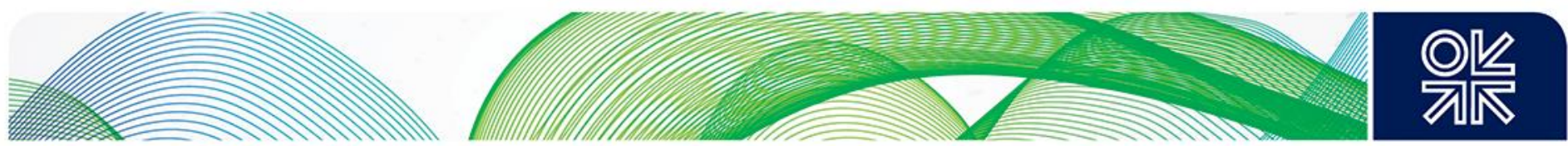

Figure 20: A range of possible outcomes for Russian gas exports to Europe

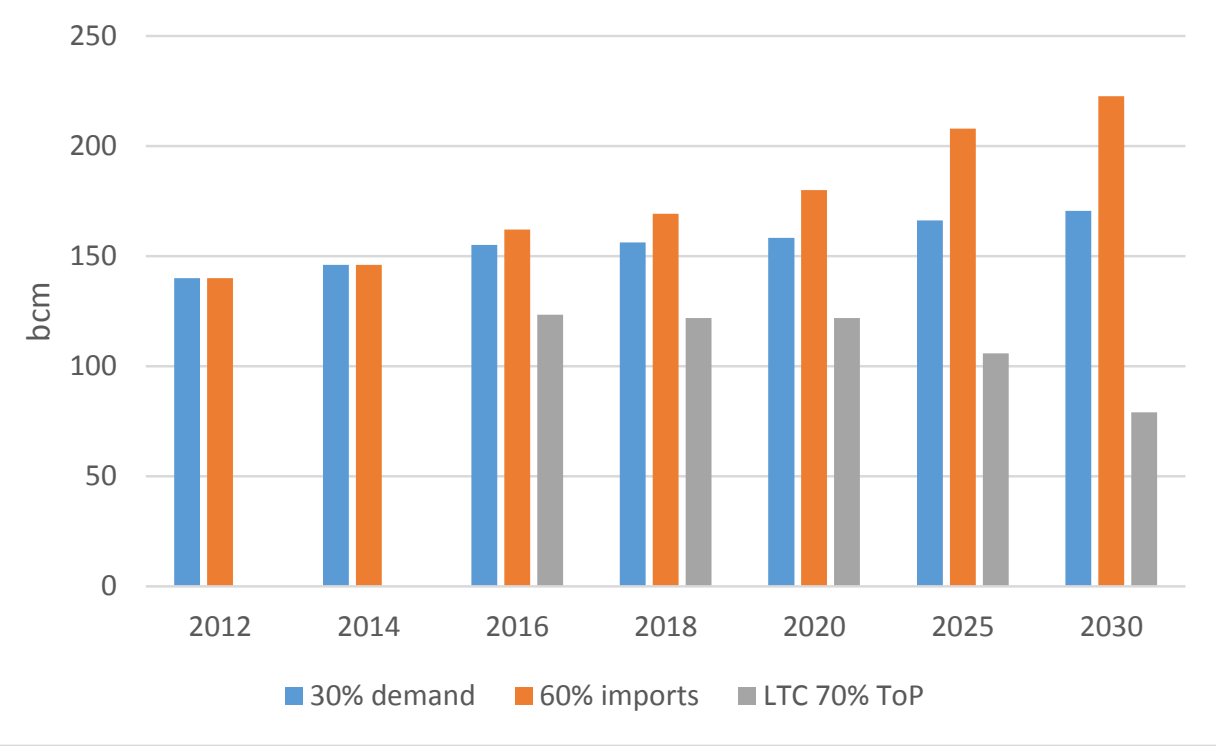

Source: Authors' calculations

\section{How might Gazprom and Russia react to commercial and legislative pressure? Is a compromise solution inevitable?}

An obvious conclusion to be drawn from Figure 20 is that the middle case appears to be a convenient compromise outcome for all parties, and is therefore most likely to occur. It meets Gazprom's market share objective, it prevents Europe's exposure to Russian gas increasing beyond current levels and it allows for the entry of significant amounts of new LNG that can offer diversity and price competition. It is also supported, at least to 2020 , by the long-term contracts that are currently in place, providing volumes that sit mid-way between the take-or-pay and ACQ levels. Indeed it would appear that Gazprom is assuming that this rather benign outcome will result from a continuation of the current market status quo, as it understands that the high case scenario is likely to be politically unacceptable while the low case scenario would risk a significant increase in the European gas price in order to incentivise sufficient development of new LNG projects.

However, there are a number of variables that could disturb this calm picture, and as a result the most interesting element of Russia's gas export strategy concerns how it might react to these or even anticipate them. The variables include, in no particular order, the anticipated oversupply of LNG in the global gas market in the period from 2015 to the early 2020s; lower than expected Asian gas demand; the imminent arrival of US LNG onto the global gas market; the continuing rise of renewables in Europe and the increased focus on reducing the use of hydrocarbons; the changing governance structure of European utilities sector; the possibility of an increase in the oil price; Russia's apparent determination to reduce the use of Ukrainian transit; and the continued emphasis in Europe on liberalising energy markets and diversifying the region away from Russian gas. These drivers are inter-linked in many ways and have overlapping consequences and timescales that create a very complex matrix of outcomes to which Gazprom and the Kremlin may have to respond. 

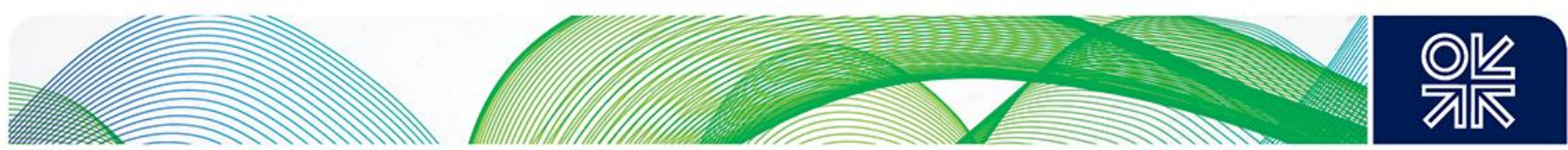

\section{Potential impact of US LNG in Europe}

The imminent start-up of a large number of new LNG projects has been well documented in a number of sources, most recently in the IEA's Medium Term Gas Report (IEA 2015) where $175 \mathrm{bcm}$ of new gas output is estimated to be due to arrive on the global gas market in the period 2015-2020. ${ }^{174}$ In the short-term the majority of this will come from Australia, but the launch of the Sabine Pass liquefaction terminal on the Gulf coast of Louisiana at the end of 2015 will also mark the start of a surge in US LNG exports for the first time. ${ }^{175}$ The Australian gas will be targeted mainly at the Asian market, but importantly could displace current spot supplies that may then revert to Europe, which is likely to continue to act as a sink for any LNG that is surplus to requirements elsewhere. The destination of the gas from the US is much more difficult to determine, as much of it has been sold to aggregators such as BG who will add it to their global portfolios to be sold into the most profitable destination. For some this may be Europe as a primary market, ${ }^{176}$ in particular because lower oil prices have currently reduced the competitiveness of Henry Hub-based gas in Asia, ${ }^{177}$ meaning that the economics of US supply are of great importance to Gazprom.

As described by Cheniere Energy, the first significant developer of a US LNG export site, the full cost economics of US LNG are calculated by taking the spot price of US gas (generally taken as the Henry Hub price), adding $15 \%$ for shrinkage, transport and trading costs, then adding the cost of liquefaction (generally a tolling fee), marine transport and regasification. In the case of sales to Europe, at the

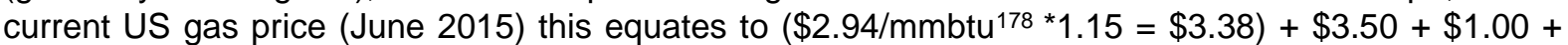
$\$ 0.50=\$ 8.38 / \mathrm{mmbtu} .{ }^{179}$ However, this is the Long Run Marginal Cost of US LNG and as Figure 21 shows, the Short Run Marginal Cost, assuming that the liquefaction cost is sunk, is clearly much lower. Indeed, even if the Henry Hub price were to rise significantly (which many forecasters think unlikely) US LNG can remain very competitive in Europe on a short-run marginal cost basis compared to both the current NBP spot price and Gazprom's average LTC price.

Figure 21: The cost of US LNG versus European gas prices

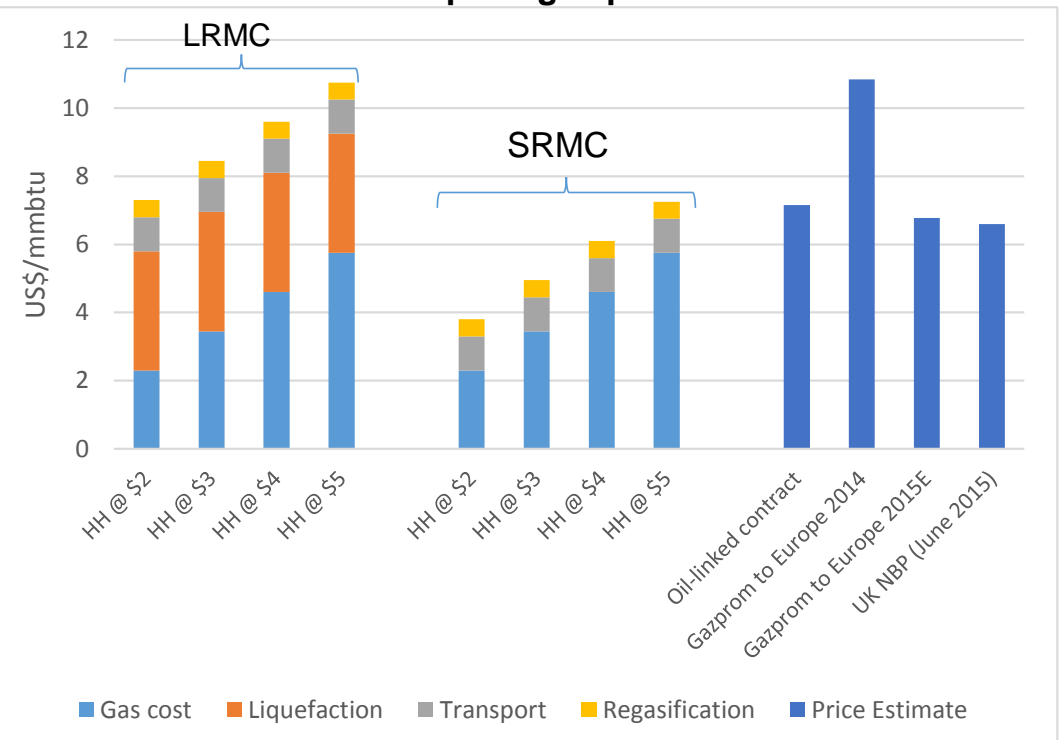

Sources: Cheniere Energy, Energy Intelligence, Gazprom (n.b. oil-linked contract calculated at an oil price of $\$ 65 /$ barrel)

\footnotetext{
174 IEA (2015), p.112

${ }^{175}$ Wall Street Journal, 22 Feb 2015, "Cheniere: First LNG Export Facility to Start in Late 2015"

${ }^{176}$ Reuters, 21 Feb 2014, "As global gas output surges, US seen to rival Russia in Europe"

177 Wall street Journal, 7 May 2015, "Why cheap oil is bad news for US natural gas"

178 Henry Hub price on 17 June 2015

${ }^{179}$ Costs sourced from Cheniere Energy presentation to investors, January 2014, slide 5
} 

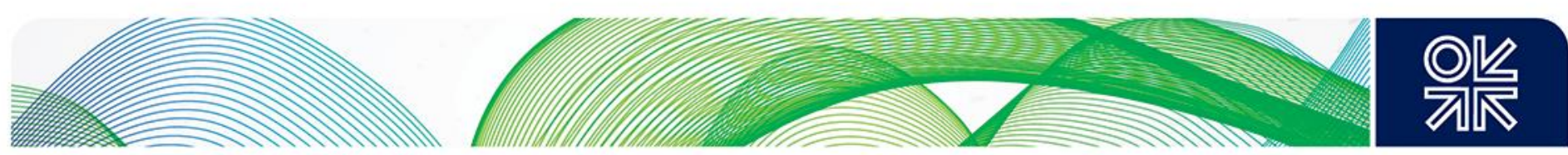

However, it is also apparent from Figure 21 that any company considering a new LNG export facility in the US will undoubtedly be cautious, given the fact that the full cost of a new facility at the current Henry Hub price would not produce gas competitive with the UK spot price or with Gazprom's anticipated sales price in Europe in 2015, following the fall in the oil price. ${ }^{180}$ However, any existing plant where the liquefaction cost is sunk, or any aggregator of US LNG who has committed to paying a tolling fee already, will be prepared to sell gas into Europe at a price that covers the Henry Hub gas price plus transport and regasification, which at the current US gas price equates to below $\$ 5 / \mathrm{mmbtu}$. Indeed the Henry Hub price itself would need to rise to $\$ 5 / \mathrm{mmbtu}$ before US LNG exports became uncompetitive in Europe on an SRMC basis.

As a result, Gazprom (and other pipeline suppliers to Europe) need to carefully consider their response to the arrival of a new source of competition providing gas under an alternative pricing formula. During 2015 the lower oil price has effectively brought Gazprom's oil-linked price into line with the European spot gas price and with the potential competition from the US. However, if the Brent oil price starts to rebound towards the $\$ 70-75 /$ barrel range suggested by the forward futures curve then the gap between the oil-linked price and hub-based prices, which will be influenced by the arrival of cheaper US LNG, is likely to open again, leaving all holders of oil-linked contracts in a difficult position. ${ }^{181}$ Gazprom has certainly argued that it would be prepared to compete with US LNG as and when it arrives in Europe, although it currently appears to believe that it can do so under its current long-term contract terms due to the reduction in prices over the past year. ${ }^{182}$ However, the risk of US LNG being priced at SRMC levels presents a clear threat to Gazprom's position in Europe, especially as gas from North America is being presented in some quarters as a political solution to the EU's security of supply issues. ${ }^{183}$

The threat of US gas arriving in Europe may also prompt a political reaction in Russia, given that relations between the two countries are tense, but irrespective of this a more pertinent commercial problem for Gazprom may be the impact on its existing long-term contracts. As mentioned above, these do provide Gazprom with some security of demand, at least to 2020, but it is in precisely this period that its customers are likely to see surplus LNG from the US, Australia and other new producers arriving on the global market, leading to a possible supply glut in a market where demand in Europe is stagnant and in Asia is showing less than expected growth. The low spot market prices (below $\$ 8 / \mathrm{mmbtu}$ in both Europe and Asia) that have initially emerged as a result of a falling oil price could therefore be set to continue, and have the potential to prompt further renegotiations of long-term contracts similar to those seen in the 2010-2014 period. However, while the timing of any discussions will clearly be dependent on a difference between spot prices and contract prices emerging, there are a number of other structural reasons to believe that Gazprom's LTCs may not necessarily provide the insurance that the company anticipates.

\section{Gas demand issues in Europe}

In addition to the risk of gas oversupply in Europe, risks to Gazprom's position could also come from demand side issues, market reform and changes in the corporate landscape. The supply and demand scenarios analysed above describe a world in which European gas demand recovers slowly due both to a gradual economic recovery but also due to two key policy drivers concerning competing fuels. Firstly, coal-fired power plants are due to be phased out over the next five to ten years as the Large Combustion Plant Directive and the Industrial Emissions Directive come into force. ${ }^{184}$ This should clear a space for alternative fuels such as gas, but as of August 2015 the price of the latter remains

\footnotetext{
180 Financial Times, 29 April 2015, "Gazprom predicts export gas price to fall due to cheaper oil”, in which Alexander Medvedev estimates an average Gazprom sales price in Europe of $\$ 242 / \mathrm{mcm}((\$ 6.78 / \mathrm{mmbtu})$ in 2015

${ }_{181}$ Data sourced from http://www.barchart.com/commodityfutures/Crude Oil Brent/CB?search=CB* on 17 June 2015

182 Forbes, 11 Mar 2015, "Gazprom says it can compete with US LNG in Europe"

183 Bordoff \& Houser (2014), p.3

184 See http://ec.europa.eu/environment/industry/stationary/lcp/legislation.htm, accessed 22 June 2015
} 

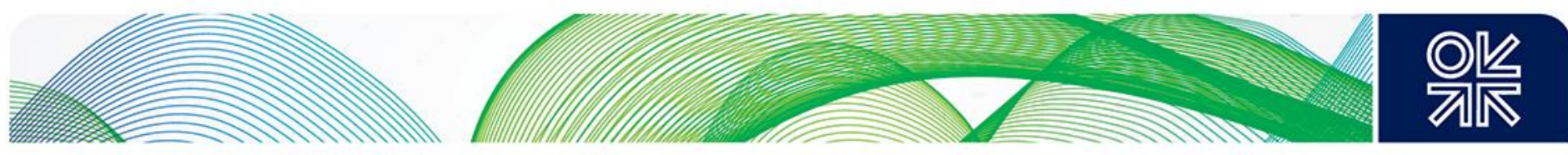

uncompetitive relative to coal leading to the paradoxical situation in which a number of countries have been switching away from rather than towards gas. ${ }^{185}$ With national energy policies set to play an important role in the future of both fuels, in combination with but not necessarily subordinate to EU regulation, it remains unclear exactly how fast coal will be displaced, especially in the power sector where some countries are still building new coal-fired stations, meaning that gas demand could be lower than expected if it remains expensive on a relative basis.

In addition to this possible downside scenario, the future of nuclear power and renewables will also be of vital importance to the outlook for gas demand. The question of nuclear power in Europe is creating significant debate, with countries such as Germany, Italy and Belgium seemingly committed to removing nuclear from their energy mix, while others such as France and the UK seem equally ready to maintain or expand their use of nuclear as a means to reducing carbon emissions. However, uncertainty over the eventual outcome is apparent as countries preparing for nuclear shutdown question the speed of removal of an energy source that is relatively cheap and clean (once already constructed), ${ }^{186}$ while countries looking to expand question the cost of new facilities. ${ }^{187}$ The impact of the answers could be significant for the gas sector as nuclear power provides $28 \%$ of electricity output in the EU, and any decision to slow the planned phase-outs could provide a further dampening of gas demand expectations.

A more general concern to all producers of hydrocarbons, which is linked to the position of nuclear and coal in the energy mix, is the rise of renewable energy as a source of clean fuel in the power sector, especially as it is becoming increasingly competitive with fossil fuels. Although Gazprom has regularly downplayed the potential impact of renewables in Europe because of the cost of the financial support mechanisms that have historically been needed to sustain this new energy source, ${ }^{188}$ analysis by IRENA ${ }^{189}$ suggests that solar power and onshore wind are at least approaching grid parity, ${ }^{190}$ while the IEA has also produced research that supports the argument that renewable costs are falling quickly and may soon reach a level where the industry can be sustained without financial support. ${ }^{191}$ The speed of adoption of renewables in Europe is also accelerating, and the IEA expects this to continue over the next 25 years, during which time it believes that renewables will account for $70 \%$ of all power generation investment in the region and that regional investment will equate to almost one quarter of global spending on renewables. ${ }^{192}$ Clearly this is a trend over which Gazprom and other gas suppliers have no influence, but it nevertheless suggests that, in addition to the new supply of gas which is set to arrive on the European gas market, there should also be a concern over any significant expectations of gas demand growth. Indeed some commentators are already suggesting that demand will remain weak until the mid-2030s. ${ }^{193}$

\section{Corporate structure of European gas sector and Gazprom's long-term contracts}

Perhaps even more important than the impact on gas demand, though, could be the impact of renewables on the structure of the utilities sector in Europe which, as mentioned earlier, is already under pressure from the evolution of the gas market itself. Stern and Rogers (2014b) have highlighted how the business model for mid-stream energy trading companies in Europe is becoming gradually obsolete, as they try to balance managing a supply portfolio of oil-linked and hub-based contracts with

\footnotetext{
${ }^{185}$ Cedigaz (2014), pp.9-10

186 Scientific American, 16 Mar 2014, "Will Germany really phase out nuclear by 2021?"

187 Financial Times, 25 Nov 2013, "French mood cools on nuclear question"

188 Gazprom press release, 21 Feb 2011, "From illusions to realities" sourced from

http://www.gazprom.com/press/reports/2011/eternal-values/ on 22 June 2015

189 The International Renewable Energy Agency

190 IRENA (2015) p.12

191 IEA (2013) pp.217-221

192 IEA (2014) p.272

${ }^{193}$ Financial Times, 23 Oct 2014, "Europe gas demand to stay weak until mid-2030, says IEA economist"
} 

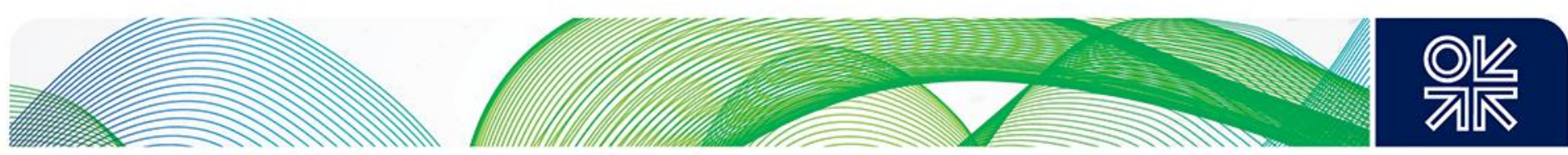

a consumer base that has increasing access to market-based volumes and prices. ${ }^{194}$ These problems could be further exacerbated by the rise of renewables in the power generation mix, which will further decentralise the energy market and put incumbent operators under pressure to change their entire business model. Two priorities in this transition could well be an accelerated move away from oillinked pricing to hub-based pricing in many European markets, and also the possible termination or radical adjustment of long-term contracts in order to reduce risk exposure and increase flexibility in a rapidly changing marketplace. One prime example of this shift in the European utility model is the split of E.ON into two businesses, one focussing on fossil fuels and nuclear while the other becomes a renewables-based business. ${ }^{195}$ As discussed by a number of commentators, this trend is set to continue across the power sector in Europe, with a focus on the need for more flexible hydrocarbon supply to provide the back-up generation to support the growing share of renewables in the electricity sector. ${ }^{196}$

As a result of these significant changes in the European power sector it is becoming apparent that Gazprom's traditional long-term contract model based on oil-linked prices could become increasingly untenable for its core customers over the next few years. However, an additional issue is that Gazprom itself may find its pricing methodology is also incompatible with its marketing strategy as it attempts to alter the direction of its gas supplies to Europe. In particular, one consequence of the shift from the South Stream pipeline to Turkish Stream, if it ultimately occurs, could be the renegotiation of any long-term contracts for gas that currently passes through Ukraine, if Gazprom insists on delivering all the gas to the Greece-Turkey border instead. All the contracts include a clause defining the delivery point, and although Gazprom has not expressed an intention to change this, its belief that new infrastructure will be built by companies other than Gazprom to move the gas from Greece to its final stipulated destination may be misplaced. In this case, if there is a question about where the gas will be delivered and renegotiation is required, then this situation could provide consumers with the opportunity to initiate discussions on a variety of other issues such as pricing, flexibility and contract length, with the possibility of a complete overhaul of the existing terms.

Gazprom has certainly started to imply that its sales strategy is changing and that it may sell its gas at the borders of Europe, with CEO Alexei Miller stating that "the decision on stopping South Stream is the beginning of the end to our operation model of the market [sic] within which we oriented ourselves towards supplying the end consumer...If the buyer doesn't want the purchase to be delivered home, well then perhaps he needs to get dressed and go to the store.... In our case the store is certainly the delivery point on the Turkish-Greek border." ${ }^{197}$ Miller elaborated further on this change of strategy during a speech to the Valdai Club in April 2015, where he discussed the fact that the traditional "interlocking and interdependence" model between Gazprom and its customers had now been radically altered. Using the relationship between Gazprom and its German customers as a specific example, he explained the Russian view that the integration of the gas chain by producers and consumers from the well-head through to the end-user had now been replaced by a "model of pure diversification" within which both parties needed to consider the increased risks involved. 198 Furthermore, he suggested that this new model is at the heart of the European Commission's energy security strategy which is embodied in the European Energy Union project, with the further implication that this has created a situation in which "Russian gas is being fought against." 199

However, once again the improvised nature of Gazprom's strategy is highlighted by its actions, as although Miller's statements suggest a change of strategy in Europe the company now appears to be having second thoughts. Having initially declared that it no longer wished to be involved in the delivery

\footnotetext{
194 Stern J. and Rogers H. (2014) pp.75-76

195 Financial Times, 2 Dec 2014, "E.ON split driven by technology"

${ }^{196}$ AD Little, Prism 2/2014, "Radical change for European Power Utilities" sourced from http://www.adlittle.nl/prism nl.html?\&view=425 on 22 June 2015

${ }^{97}$ Interfax, 6 Dec 2014, "Europe will have to care about delivering Russian gas from the Turkish border"

198 Speech by Alexey Miller at conference "Europe and Eurasia: Towards the New Model of Energy Security", sourced from http://www.gazprom.com/press/miller-journal/029076/ 23 June 2015

${ }^{9}$ http://www.gazprom.com/press/miller-journal/029076/ 23 June 2015 , final paragraph
} 

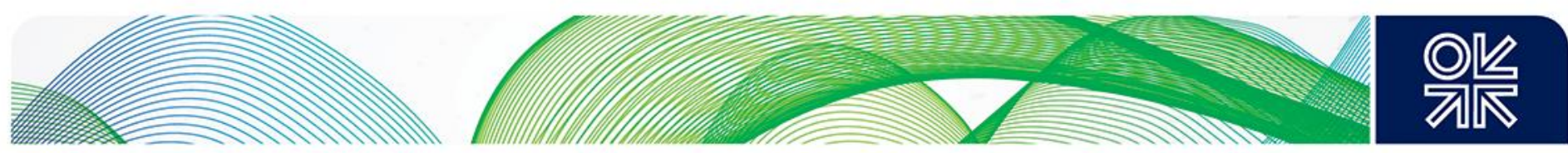

of gas to end-consumers in Europe, Gazprom reinforced this statement by ending its plans to take its stake in Wingas, a marketing company in Germany, to $100 \%$. It had originally planned to increase its exposure to the European downstream market using this vehicle, ${ }^{200}$ but then changed its mind and confirmed its new tactics by the announcing plans to also sell its $10.5 \%$ stake in VNG, another German gas supplier. ${ }^{201}$ However, Gazprom has now reversed its decision on Wingas again, completing the original swap agreement in September 2015.202 It is unclear whether this implies a complete reversal of the company's downstream strategy in Europe or whether it is another example of the desire of senior management and the Kremlin to create options for Russia and Gazprom in their major export market. In either case, though, it points once again to the evolving nature of Russia's gas export strategy as it navigates the changing commercial landscape in the European gas market.

\section{Impact of European Commission regulations and investigations}

Russia's concern about attacks on its position in the European gas market and the increased risks it faces there has been reinforced by statements from Donald Tusk, the President of the European Council, who has been a strong advocate for a European Energy Union in order to "end Russia's energy stranglehold" 203 and who warned German Chancellor Angela Merkel to take actions "so that dependence of Russian gas doesn't paralyse Europe when it needs...a decisive stance." ${ }^{204}$ However, Tusk's original concept of a single unified European body to negotiate with Russia over gas contracts has since been modified into a more generic Energy Union strategy involving the continued liberalisation of energy markets, increased interconnection between countries and the potential for oversight of contract negotiations by an EU body when requested by individual member countries. ${ }^{205}$ As a result, Gazprom has been able to take an increasingly conciliatory stance, with Alexey Miller suggesting that "speaking of the Energy Union project...we think that it contains some interesting ideas and provisions," and that "Gazprom is ready to work with the European Commission in the European market even within this model." 206 It is becoming clear, therefore, that Gazprom is starting to adapt its rhetoric, and potentially even its strategy, to accommodate the emerging EU regulation, with the decision to scrap the South Stream pipeline a clear indication of the company's acceptance that the project could not continue unless the EU was satisfied both that it complied with European gas market rules and also that the Bulgarian procurement process had been conducted fairly.

Furthermore, Gazprom's relatively calm and unexpectedly understated reaction to the European Commission's Statement of Objections concerning the company's activities in the European gas market (issued by DG COMP in April 2015), can also be interpreted as an indication that a change in strategy is gradually taking place. The details of the three main accusations have been discussed above, but it is informative to note that the only clear Gazprom reaction has been against the charge of unfair pricing, which even the Commission itself attested was hard to define. ${ }^{207}$ Alexey Miller, again in his speech to the Valdai Club, underlined how difficult it is to decide what is an unfair price, given the different energy mix within each country, and DG COMP itself in its original statement confirmed that setting different prices to different customers is not a grounds per se for complaint against any supplier. The key question is whether Gazprom's use of oil-linked pricing has created an artificially high price for any of its customers, but this may also be difficult to prove. As for the other charges, any

\footnotetext{
${ }^{200}$ Wall Street Journal, 18 Dec 2014, "BASF, Gazprom call off asset swap amid political tensions"

201 Reuters, 6 April 2015, "Russia's Gazprom plans to sell stake in German gas group VNG"

202 Interfax, 4 Sept 2015, "Gazprom, BASF held asset exchange that was delayed due to political motives"

${ }^{203}$ Financial Times, 21 April 2014, "A united Europe can end Russia's energy stranglehold"

${ }^{204}$ EurActiv, 11 Mar 2014, "Tusk warns Merkel against Russian gas addiction”, sourced from

http://www.euractiv.com/energy/tusk-warns-merkel-russian-gas-ad-news-534039 on 23 June 2015

205 Financial Times, 13 April 2015, "The EU is quietly shaping its energy union"

${ }^{206}$ Speech by Alexey Miller at conference "Europe and Eurasia: Towards the New Model of Energy Security", sourced from http://www.gazprom.com/press/miller-journal/029076/ 23 June 2015

European Commission Press Release, 22 April 2015, "Antitrust: Commission sends Statement of Objections to Gazprom Factsheet" at http://europa.eu/rapid/press-release MEMO-15-4829 en.htm, accessed on 26 June 2015
} 

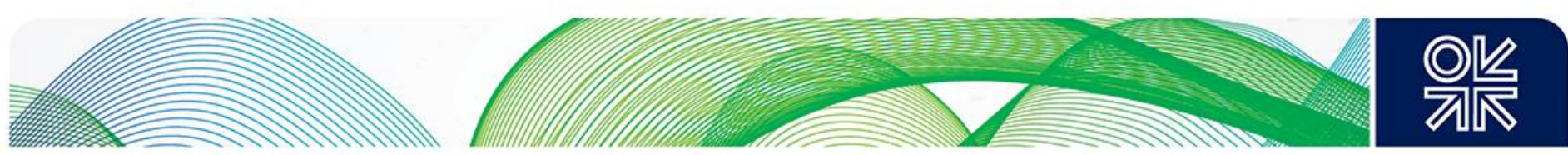

of the contracts under investigation that did contain restrictions on forward sale (destination clauses) were clearly illegal, and as this certainly appears to have occurred in a number of cases fines could be levied as a result. However, the fact that all the charges relate to a period before 2014 means that it is almost certain that the destination clauses have now been removed, making the charge something of a non-issue. The same may also be true of the accusation that Gazprom linked prices to pipeline deals in Poland and Bulgaria, given that the Yamal Europe line through Poland has now been in operation for more than a decade and the South Stream line through Bulgaria has been cancelled. As a result, it is perhaps not surprising that Alexander Medvedev, the deputy chairman of Gazprom's management board, was able to make a fairly sanguine response to the publication of the Statement of Objections, saying "the story with the European Commission is not new. It's just that it has moved to the formal course with the issue of the statement of objections. And we, like before, will respond to these claims like respectful people, with argumentation." Furthermore, in terms of the consequences that could emerge, he further stated that "besides fines, there could be an agreement to assume certain obligations within the context of the discussions...therefore we believe that this is not just a question of a monetary fine, particularly since we weren't speeding." ${ }^{208}$

\section{A commercial reaction from Gazprom?}

Gazprom's apparent calm in the face of the accusations of malpractice by the European Commission, as well as its confidence that both the future of gas demand in Europe is robust despite the challenges of renewables and cheap coal and that the future of Russian exports is also secure thanks to declining European production, suggests again that the company's preference would be to maintain a contractual and pricing strategy as close to the current status quo as possible. Even the threat of a surge in LNG supply, led by Australia and the US, does not seem to have caused any major concern, with Alexander Medvedev continuing to state in respect of US shale gas that "as a model, it's not sustainable," 209 while he has expressed the opinion that "I don't anticipate that the LNG exports from the United States could reach big volumes."210

Nevertheless, despite this outward bravado it is also apparent that the company is preparing for a changed landscape in the European gas market. As mentioned above, Gazprom has already shown its willingness to respond to market forces through the renegotiation of contract terms, with the average level of its contract prices in Europe having returned to the same level as the average spot price in the first quarter of 2015 (see Figure 14 above). Although Gazprom still formally follows the traditional oil-indexation rhetoric, it has in fact already significantly reviewed its pricing policy. During the period $2009-2014$ nearly 60 gas supply contracts were reviewed with 40 clients, providing price discounts, easing of take-or-pay obligations and the introduction of a spot component. Furthermore, by 2014 Gazprom had already provided an average 15\% discount (around $\$ 70 / \mathrm{mcm}$ ) to its European customers compared to its pre-crisis traditional oil-linked price formulas, rising to $20 \%$ or more in some instances in 2014 itself. ${ }^{211}$

In addition, it has also reacted in instances where specific pressure has been applied, where, for example, countries that have historically been reliant on Russian gas have demonstrated a new diversity in their supply options, with Ukraine and Lithuania being the most obvious examples. The former has established the ability to purchase "reverse flow" gas from Europe from countries such as Poland, Hungary and Slovakia, which have all been prepared to send gas back into Ukraine via pipelines that normally export Russian gas to the rest of the continent. ${ }^{212}$ This new source of supply has not been without its technical challenges, but nevertheless it has catalysed an immediate reaction

\footnotetext{
208 Interfax, 30 April 2015, "Gazprom advised to study Fifty Shades of Grey for talks with EC"

209 Platts, 17 Oct 2013, "As world waits for US LNG, Russia's Gazprom plays it cool"

210 Moscow Times, 20 Feb 2012, "Gazprom sees competition from US only in 10 years"

${ }^{211}$ Mitrova, T. (2015), pp. 39-40

212 Reuters, 23 Jan 2015, "EU reverse gas flow capacity to Ukraine to rise"
} 

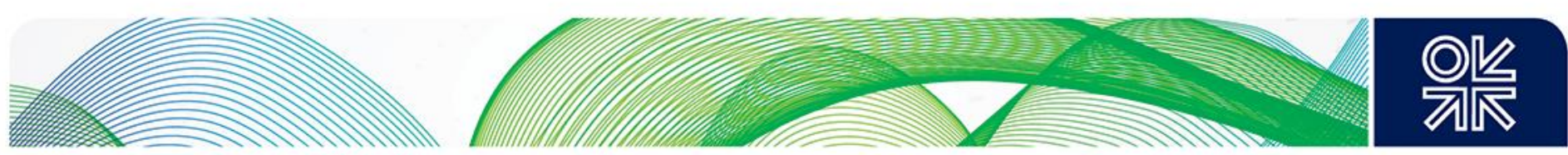

from Gazprom. In spite of the obvious political problems that exist between Moscow and Kiev, and the fact that many observers have assumed that Russia would continue to use gas as a "weapon" to exert further pressure on the Ukrainian authorities, Figure 22 below demonstrates that Gazprom has in fact reduced its prices to Ukraine in direct competitive response to the challenge of reverse flow gas. ${ }^{213}$

Figure 22: Ukraine gas imports from Russia and Europe

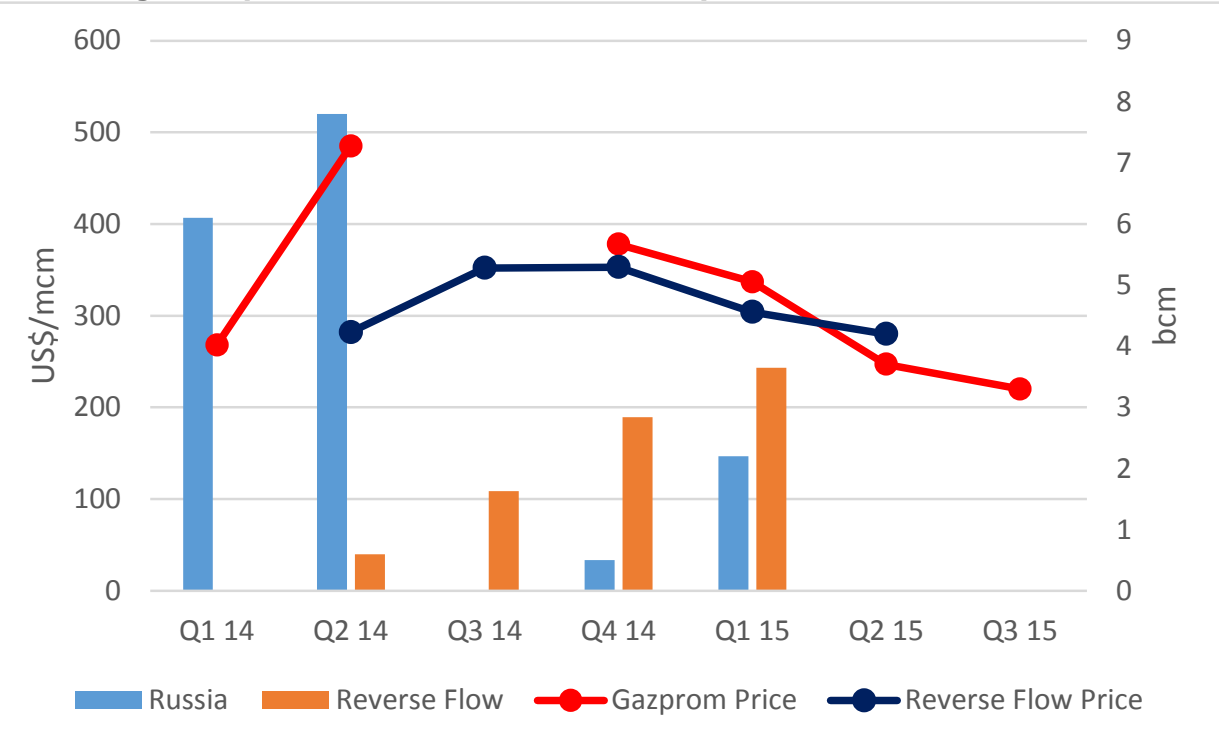

Source: Pirani (OIES)

In Q1 2014 Gazprom was still selling gas to Ukraine at a previously agreed discounted price, but in Q2 the discount was removed following the annexation of Crimea and the start of the conflict between the Ukrainian government and separatist movements in the east of the country. At this point Ukraine began to explore the potential for reverse flow gas, with first volumes flowing in Q2 but accelerating through the rest of the year as alternatives to Russian gas (which was actually cut of in Q3 due to a non-payment dispute) were sought. As soon as this started to occur, Gazprom responded with a price negotiation that brought the cost of Russian gas down to the level of reverse flow gas, even reaching a discount in Q2 2015. As a result the flow of Russian gas started to rebound, in spite of the continuing political problems that have prevailed throughout the period, providing clear proof of Gazprom's willingness and ability to respond to commercial pressure.

Indeed it is also interesting to note the failure of the company's more political response to the issue of gas flowing back into Ukraine from Europe at the end of 2014 and the beginning of 2015. Effectively reverse flow gas to Ukraine is supply purchased under take-or-pay terms from Russia by other countries that is then re-directed to a third market (Ukraine), and in an apparent attempt to stop this occurring during the winter of 2014/15 Gazprom adopted a policy of restricting gas flows to various customers in Europe. ${ }^{214}$ However, the cost of this strategy, which may also have involved an attempt to support hub prices in Europe through restricting gas flows to other countries without the ability to send gas to Ukraine, appears to have been high, with some estimates putting the loss to Gazprom as high as $\$ 6$ billion. ${ }^{215}$ In addition, although reverse flow was limited for a time, continued demand weakness in European gas markets also meant that Gazprom's actions were rendered ineffective in as much as prices continued to fall and any volumes it held back could be replaced by alternative suppliers. As a result the strategy was abandoned at the end of Q1 2015.

\footnotetext{
${ }^{213}$ Reuters, 21 Mar 2015, "Russia will have to sharply lower gas price, Ukraine says"

${ }^{214}$ Bloomberg, 10 Sept 2014, "Gazprom limits Polish has supplies as reverse flows halt" and Financial Times, 26 Sept 2014,

"Hungary halts flow of gas to Ukraine"

215 Interfax, 19 Mar 2015, "Reverse flow supplies to Ukraine cost Gazprom up to \$6 billion"
} 

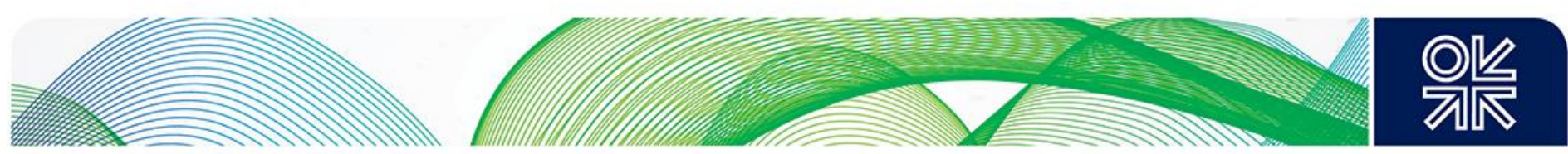

Another example of Gazprom's response to competition was provided by Lithuania, where the authorities initially took Gazprom to an arbitration court over unfair pricing practices but ultimately decided to lease a floating regasification and storage unit (FRSU) in order to break the Russian supply monopoly. The project was supported by EU funding and provided an important boost to Lithuania's bargaining power in its negotiations with Gazprom, which ultimately led to a significant reduction (estimated to be at least 20\%) in the import price of Russian pipeline gas. ${ }^{216}$ The Lithuanian gas company Lietuvos Dujos subsequently signed a 5 -year contract to import LNG from Norway at a price based on the European hubs, even though it has been reported that it is paying around $10 \%$ more for this new source of gas than for renegotiated Russian supplies. ${ }^{217}$ This underlines not only that Gazprom is prepared to compete with new LNG supply to Europe but also that it faces the potential prospect of losing market share even if it offers a lower price than its competitors if its customers are determined to diversify away from Russia and can access cheap EU finance to build the necessary infrastructure to achieve this goal.

Indeed the political nature of Europe's desire to diversify away from Russian gas is a clear source of bargaining weakness for Gazprom, and is being exploited by future exporters of US LNG who are actively lobbying potential customers in the EU via groups such as LNG Allies, whose stated mission is to "support our NATO and other allies...with enhanced fuel diversity and energy security." 218 Furthermore, as discussed earlier, Europe certainly contains adequate spare regasification capacity to import new US LNG or additional supplies from other producing countries who may have an excess over the next few years, and additional import terminals are either under construction (at Swinoujscie in Poland) ${ }^{219}$ or planned to start building soon (for example at Krk in Croatia), ${ }^{220}$ while Greece is considering the use of floating regasification facilities to supplement its existing capacity. ${ }^{221}$ As a result, Gazprom is likely to face increasing pressure from other countries across Europe to consider its pricing policy, and also the structure of its contracts given the relatively flexible nature of the LNG that is likely to be competing with it.

\section{How will Gazprom respond to the challenge?}

Gazprom has responded to this potential challenge by asserting the competitiveness of its pipeline gas versus any LNG imports, especially from the US. Indeed Alexander Medvedev has been blunt in his assessment of the cost of US LNG in Europe, stating: "Let them give us the calculations. As far as I understand, even if this is done on a very balanced basis, the price of LNG to be supplied from the United States of America will be $40 \%$ more expensive than the Russian pipeline gas." 222 However, this somewhat bold statement disguises a more complex picture that could result in a sharp decline in European gas prices if Gazprom really decides to compete with US LNG at any price.

As Figure 23 demonstrates, there is a wide range of cost of supply estimates for both Russian pipeline exports and future US LNG exports. The full cost of developing a new gas field in Russia plus associated transport costs could be as high as $\$ 10.2 / \mathrm{mmbtu}$ when delivered to Europe (including export tax) although, after the impact of the recent devaluation of the rouble is taken into account, this could fall to around $\$ 7 / \mathrm{mmbtu}$. However, as discussed above, Gazprom has a significant surplus of developed gas at present, with the capital costs of its new Bovanenkovo field having been largely sunk and its other West Siberian fields being mainly heritage assets or cheap satellite fields. As a result, a more relevant measure of the cost of Russian gas supply is the short-run marginal cost of its production and delivery to the European border. This can be calculated in two ways. Firstly, one can

\footnotetext{
${ }^{216}$ Wall Street Journal, 28 May 2014, "Gas terminal plans helped Lithuania negotiate lower price from Gazprom"

217 Reuters, 13 Nov 2014, "Lithuania to pay more for Norwegian LNG than Russian gas"

218 See http://www.Ingallies.com/mission/, sourced on 23 June 2015

${ }^{219}$ Natural Gas Europe, 30 Mar 2015, "Swinoujscie LNG terminal ready in summer if Poland provides additional support"

220 Interfax, 25 May 2015, "Croatia to start Krk LNG terminal construction by mid-2016"

${ }^{221}$ Natural Gas Europe, 21 Oct 2013, "There are several plans for floating LNG stations in Greece"

222 Interfax, 20 April 2014, "Russia should be able to supply gas to Asia as well as Europe - Medvedev"
} 

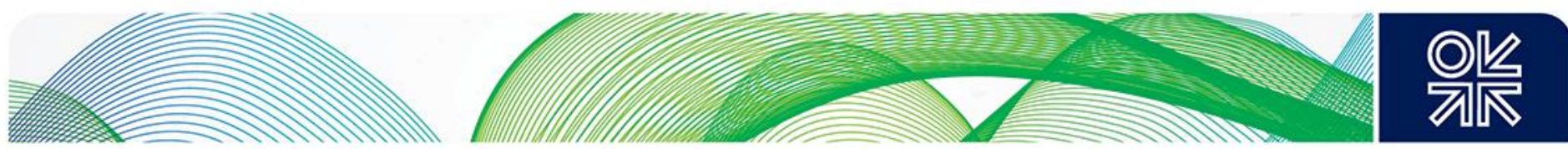

take the average lifting cost for Gazprom's gas (estimated at around $\$ 0.36 / \mathrm{mmbtu}$ ), ${ }^{223}$ add MET at RR745.mcm $(\$ 0.35 / \mathrm{mmbtu}),{ }^{224}$ plus domestic transport $(\$ 0.81 / \mathrm{mmbtu})^{225}$ and the cost of export via Nord Stream $(\$ 1.20 / \mathrm{mmbtu})^{226}$ plus export tax $(30 \% \text { of gross sales value })^{227}$ to get a delivered price at the German border of just under $\$ 4.00 / \mathrm{mmbtu} .{ }^{228}$

Figure 23: Competitive position of Russian gas in Europe

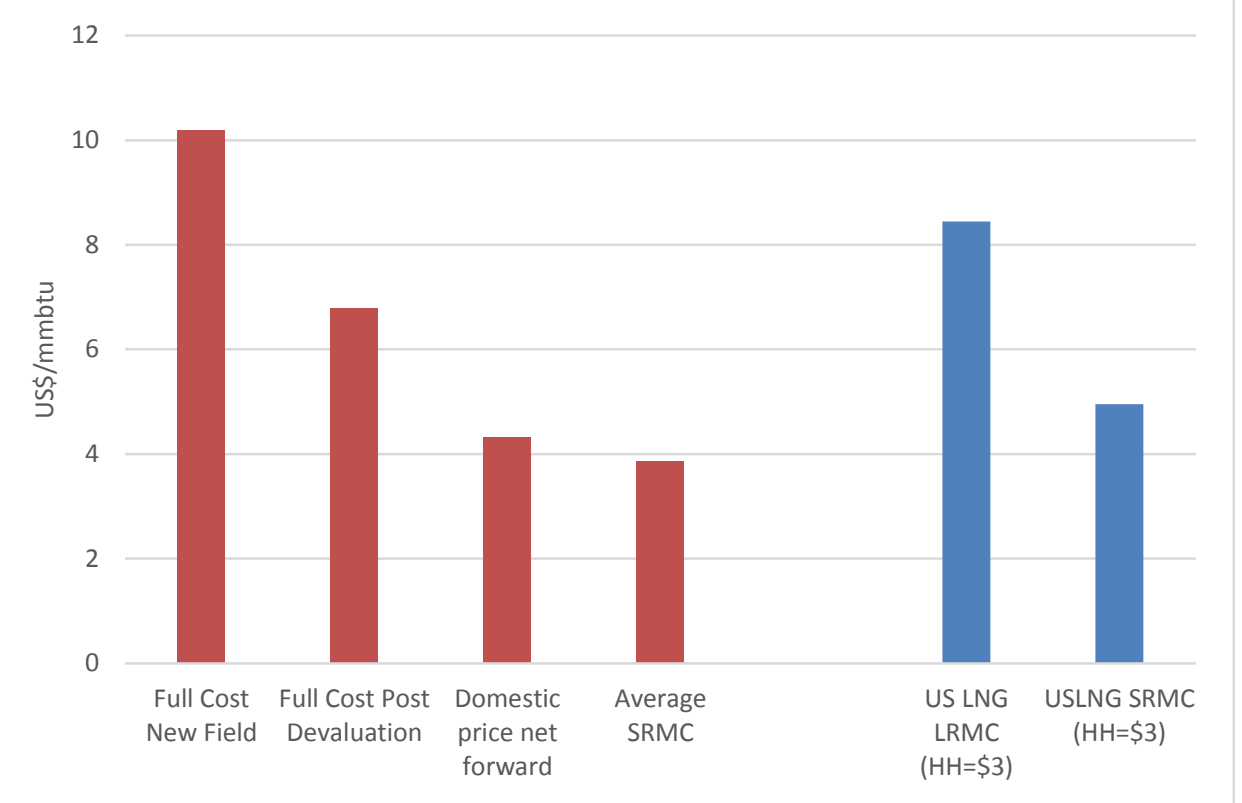

Sources: *Full Cost New Field from Mitrova et al (2015), remaining data is authors' calculations

An alternative methodology is to take the Russian domestic gas price in the Leningrad region and add the Nord Stream tariff and export tax, which gives a total gross price of $\$ 4.33 / \mathrm{mmbtu}$. ${ }^{229}$ Although a simplification, this methodology can be justified to an extent by the fact that since 2009 Gazprom has broken even or made a small profit on its domestic sales, although the company continues to argue that it is not sufficient to generate cash for reinvestment in its asset base. ${ }^{230}$

When these figures are compared with the potential cost of US LNG in Europe it is clear that while on some levels Gazprom's gas can be seen as much cheaper, if both are compared on a short-run marginal cost basis then the difference is much smaller. The full cost of US LNG exports assuming the current Henry Hub price of US $\$ 3 / \mathrm{mmbtu}$ would be approximately $\$ 8.50 / \mathrm{mmbtu}$, rising to $\$ 10.75 / \mathrm{mmbtu}$ if the US gas price rises to $\$ 5 / \mathrm{mmbtu}$. On this basis one can see how Gazprom could claim that its marginal gas exports could be much cheaper than US gas. However, if the liquefaction cost is regarded as sunk, then the marginal cost of US gas falls to a range of $\$ 5-7.25 / \mathrm{mmbtu}$, and would be $\$ 1$ lower than this if the transport cost is also regarded as sunk (if long-term tanker leases have been signed). On this basis Gazprom would have to price its gas at the very bottom end of its

\footnotetext{
${ }^{223}$ Gazprom presentation to investors, June 2015, slide 25 cites an average lifting cost of RR745/mcm, equivalent to

$\$ 0.4 / \mathrm{mmbtu}$ at an exchange rate of RR54=US\$1

${ }_{224}$ Interfax, 25 June 2015, "MET on gas for Gazprom to rise by 3.6\% to 745 rubles per 1000 cubic metres in 2015 - company" ${ }_{225}$ Gazprom presentation to investors, June 2015, slide 25 cites an average transportation cost of RR58.9/mcm/100km.

Assuming a transport distance from Nadym pur Taz to St Petersburg of approximately $3,500 \mathrm{~km}$ this implies an overall tariff of $\$ 38 / \mathrm{mcm}$ (at an exchange rate of RR54=US\$1), or $\$ 1.07 / \mathrm{mmbtu}$

${ }^{226}$ Interfax Energy, 11 Sept 2014, “Nord Stream tariff drops to $\$ 3.5 / \mathrm{mcm} / 100 \mathrm{~km}$." The Nord Stream pipeline extends $1,222 \mathrm{~km}$ from the Russian border to Germany under the Baltic Sea, implying a total tariff of $\$ 43 / \mathrm{mcm}$ or $\$ 1.20 / \mathrm{mmbtu}$

${ }^{227}$ Export tax is calculated as $30 \%$ of the gross sales value of the gas in Europe. To calculate a breakeven cost including export tax it is therefore necessary to sum the total costs and divide by 0.7 to reach a full gross price

${ }^{228}$ Calculations assume a rouble exchange rate of $\$ 1=\mathrm{RR} 60$

229 The domestic gas price in Leningrad in 2014 was RR3921/mcm

${ }^{230}$ http://www.gazprom.com/press/news/2014/april/article189315/, accessed on 25 June 2015
} 

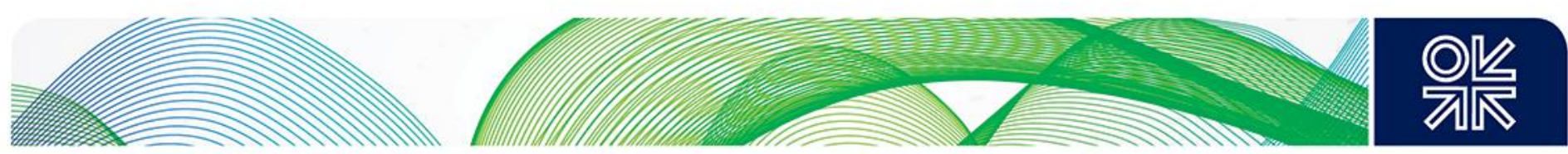

marginal cost range in order to keep surplus US gas that could be searching for a spill-over market in Europe (assuming that Asian demand had been satisfied) from reaching end consumers.

\section{Would Gazprom consider proactively reducing the gas price in Europe?}

Given the low marginal cost of both Russian pipeline gas and US LNG the possibility of a price war in the European gas market would seem to be one logical conclusion of this analysis, especially given the potential for an oversupply of LNG in the period to the early 2020s. However, for this to occur Russia and Gazprom would need to decide that defence of market share in Europe had become a priority, whereas historically the company has shown a preference for maximising price where possible and sacrificing volumes if necessary. ${ }^{231}$ Having said that, there are a number of logical reasons for Gazprom to consider a more proactive low price strategy, at least in the short-term.

The first reason might be political, in direct response to LNG from the US rather than any other source. As shown in the supply and demand analysis above, there would appear to be room for Gazprom to meet its market share objectives and for LNG imports to Europe to increase over the next fifteen years. However, if President Putin decides that that he needs to respond to the challenge of US gas acting as a saviour for Europe against increasing dependence on Russian gas, then a reaction to the first arrival of US LNG into Europe could be significant. Furthermore, if US sanctions are still in place at this time and if the US has taken further steps in Europe that could be viewed as antagonistic by the Russian side (such as the placing of US military equipment in the Baltic States), ${ }^{232}$ then again Putin may feel that a response in the gas market may be one means to express Russia's antipathy.

Beyond politics, though, the future of gas demand in Europe may also encourage a lower gas price strategy. In particular the displacement of gas by coal in the power sector in a number of countries over the past few years (in particular in Germany and the UK) might suggest a need for gas to compete on price with coal for power generation. Analysis by Timera Energy (2015) shows that in order to see switching from coal to gas for base load the gas price in Europe needs to fall from its current level of around $\$ 7-8 / \mathrm{mmbtu}$ to $\$ 5 / \mathrm{mmbtu}$ or below. This very low price for gas is caused both by the currently depressed price for coal imports (driven to an extent by coal displacement by gas in the US) but also by the ineffectiveness of the Emissions Trading System (ETS) in Europe to set a high enough carbon price to incentivise fuel switching away from high to lower carbon emitting fuels.

It is generally estimated that the carbon price would need to increase to at least $€ 30 /$ tonne to catalyse a significant shift away from coal towards gas, and although the European Parliament has taken some initial steps to reform the ETS by removing surplus carbon allowances from the market, this will not start to take effect until the end of the decade. ${ }^{233}$ As a result, although the Large Combustible Plant Directive should catalyse the removal of some coal-fired plants over the next few years, in purely commercial terms the gas price will continue to be the most important driver of competitiveness in the power sector over the next 4-5 years. A recognition of this situation is seen in the fact that some mention has been made in Russia about offering a new lower gas price just to power companies in Europe, but as this would contravene EU law it is unlikely to become a realistic part of Gazprom's marketing strategy.

A further concern for all hydrocarbon producers, but especially for gas and coal in the power sector, is the continuing rise of the share of renewable energy and the reducing cost of its production. According to research produced by Lazard ${ }^{234}$ the cost of onshore wind generation has fallen by $58 \%$ over the past five years while the cost of solar PV has declined by $78 \%$, brining both to a level within

\footnotetext{
${ }^{231}$ Natural Gas Europe, 3 June 2014, "Putting a price on gas or Putin's gas price"

232 Reuters, 23 June 2015, "US to pre-position tanks, artillery in Baltics, eastern Europe"

${ }^{233}$ The Guardian, 24 Feb 2015, "European carbon market set for reform from 2019"

234 Lazard (2014) slide 9
} 

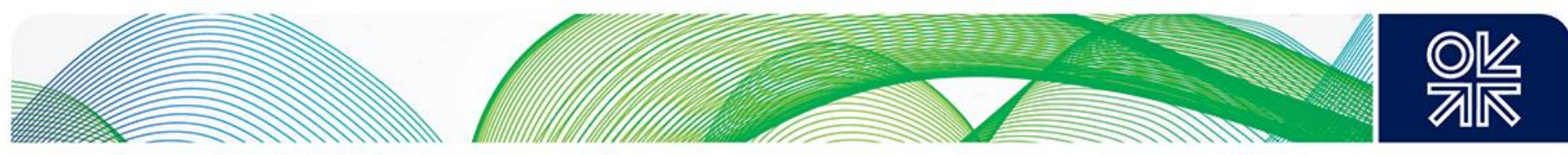

the range of gas-fired power costs. As a result of these declining costs and the continuing subsidisation of renewables across Europe, their share of total energy consumption in the EU had risen to almost $12 \%$ in 2013 , with the target to reach $20 \%$ by $2020 .{ }^{235}$ Meanwhile in the power sector the share of renewables had reached $25.4 \%$ in 2013, with wind accounting for $26.5 \%$ of the renewables total while solar accounted for $9.5 \%$, up from $0.1 \%$ over the previous decade. If the current rate of progress is continued then gas and coal face the prospect of having to compete with renewables on a full cost basis even if subsidies are removed (which is set to happen for onshore wind in the UK), ${ }^{236}$ meaning that once again the gas price will be a crucial determining factor of the future position of gas in the power sector. Indeed a low price may be essential for gas to maintain even a role as a back-up fuel, given the very low marginal cost of renewables production once the relevant equipment has been installed and the likely continuation of a low price for coal as it is gradually removed from the energy mix. Some power generating companies are even talking about a world in which hydrocarbons have no role in the power sector in OECD countries, with the chief executive of Engie being quoted as saying that: "The choice we have made is very clear. We have stopped investing - and so did others by the way - in thermal power generation in Europe and we are investing in renewables." 237

The competitive position of Russian gas relative to alternative energy sources could be further undermined if the oil price starts to recover from the low level seen in August 2015. Although general expectations are for the oil price to stay in a range between $\$ 55$ and $\$ 75 /$ barrel for the next few years, ${ }^{238}$ even a rise towards the top end of this range could leave Gazprom significantly disadvantaged versus alternative gas suppliers who price their gas on the hubs and against coal. At a time when the political mood in Europe is also for a diversification away from Russian gas, ${ }^{239}$ it would clearly make sense for Gazprom to avoid creating an additional commercial logic for a switch, and indeed it would arguably make more sense for it to ensure that its gas is competitive, and perhaps even the cheapest, in the market in order to undermine the political logic of the EU and to respond to the charges made against it by DG COMP of unfair pricing. The examples of Ukraine and Lithuania have shown that, at the right price, any country is prepared to continue buying Russia gas, despite the current momentum towards searching for alternative options, and Gazprom would therefore appear to have a reasonable opportunity to counter the political drive to diversify away from its gas if it can find the appropriate marketing and price strategy.

However, having considered the commercial logic in favour of Gazprom adopting a low gas price strategy it is also important to note three reasons why the company, and the Russian government, would be reluctant to move in this direction. Primarily the reasons are short-term in nature, and as this appears to be a feature of Russian political and corporate decision-making that has been noted by a number of commentators, ${ }^{240}$ it is likely that they will carry significant weight in deciding on Gazprom's tactics over the next one to three years.

The first reason is the impact of a lower export gas price on Gazprom. Exports to Non-FSU countries accounted for $56 \%$ of the company's net gas sales (after the removal of export tax) and $30 \%$ of the company's total net revenues in 2014. ${ }^{241}$ The average price of sales to Europe was just under $\$ 350 / \mathrm{mcm}$ in $2014,{ }^{242}$ but if this had been reduced to the average UK NBP price for the year $(\$ 8.39 / \mathrm{mmbtu} \text { or } \$ 299 / \mathrm{mcm})^{243}$ it seems certain that Gazprom's profits for the year would have been

\footnotetext{
235 http://ec.europa.eu/eurostat/statistics-explained/index.php/Renewable_energy_statistics

${ }^{236}$ BBC, 18 June 2015, "Earlier end to subsidies for new UK onshore wind farms"

${ }^{237}$ Financial Times, 21 May 2015, "Coal and gas power dying out in Europe, says energy chief"

${ }^{238}$ EIA Short Term Energy Outlook, 9 June 2015 sourced from http://www.eia.gov/forecasts/steo/report/prices.cfm on 25 June 2015

239 Financial Times, 14 Oct 2014, "Can Europe wean itself off Russian gas?"

${ }^{240}$ For example: Moscow Times, 21 Sept 2014, "Russia's short-term thinking imperils its future", and The Age, 12 June 2015 ,

"The West should prepare now for sudden and turbulent change in Russia"

241 Gazprom IFRS Accounts 2014, note 26, p.41

242 Gazprom Management Discussion and Analysis of IFRS 2014 Results, p.33

243 Prices sourced from World Gas Intelligence
} 

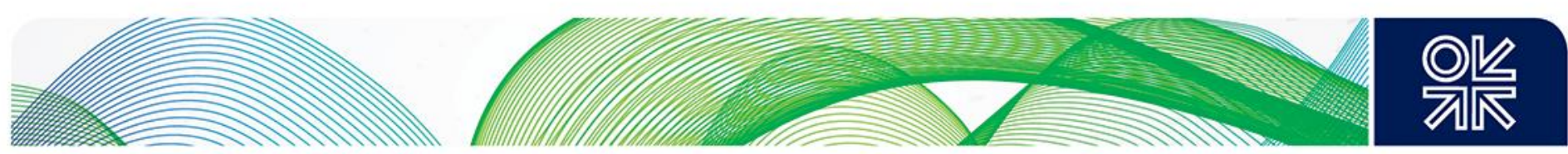

wiped out and its cashflow would also have been severely restricted. Concern over the risk of Gazprom's financial stability being undermined by a longer period of low prices in Europe is already concerning financial analysts, and so it seems unlikely that Gazprom would attempt to catalyse this outcome itself. ${ }^{244}$ Having said that, the low level of current prices even under its oil-linked formulae means that the company may not have as much to lose as it fears, as in July 2015 the price of its gas fell below the UK spot price for the first time in 18 months (see Figure 14). Nevertheless, Gazprom is unlikely to want to catalyse a continuation of this trend or a prolonged price war.

A second reason is that a reduction in the gas export price to Europe would impact Russian budget revenues via lower receipts of gas export tax. Although the Russian budget is much more reliant on oil than gas revenues, ${ }^{245}$ nevertheless in 2014 Gazprom paid RR398 billion ( $\$ 10.3$ billion) in customs duties for its Non-FSU sales, which accounted for just under $3 \%$ of the RR14.2 trillion budget total. ${ }^{246}$ As a result, a drop in the export price from $\$ 350 / \mathrm{mcm}$ to the August 2015 spot price of $\$ 220 / \mathrm{mcm}$ would cut the export tax income by approximately 150 billion roubles, or $1.2 \%$ of total budget revenues. Although this is not a dramatic figure, it is certainly significant at a time when the Russian government is already struggling to balance its revenue and expenditure during a period of low oil prices, and would provide a further short-term incentive not to proactively cut gas prices.

The third reason is more political in nature, and relates to the fact that a lower gas sales price to Europe would obviously benefit customers in countries that are currently imposing sanctions on Russia in response to its actions in Ukraine. Although the Kremlin and Gazprom appear to be doing their best to separate political and commercial activity during the current crisis, it nevertheless seems unlikely that President Putin would condone any action that could benefit the EU economically at a time when Russia's own economy is struggling through a recession catalysed by low hydrocarbon prices.

\section{A preference for the status quo, but preparation for competition}

Given this context, and Gazprom's consistently stated belief that Europe will need more rather than less of its gas over the next two decades, the preferred strategy for the company in terms of pricing and contract terms would clearly seem to be maintenance of the status quo, at the very least in the hope that events will move in its favour. Indeed Gazprom management has often been vociferous in its view that both coal and renewables will ultimately make way for gas in Europe as the former is phased out by policy initiatives while the latter is ultimately found to be too expensive in a region still struggling with economic stagnation. ${ }^{247}$ As a result, the tactic of waiting for the market to "come right" for Russian gas is clearly the preferred option, based on the assumption that Europe will have no choice as gas demand rebounds and indigenous production continues to decline. Furthermore, for Russia history also suggests that unforeseen events, such as the Fukushima accident or the political upheaval in North Africa, ${ }^{248}$ have tended to disrupt the market on a regular basis, providing additional hope of an upturn in Gazprom's fortunes.

However, despite this preference for the status quo it would be wrong to equate this with a "do nothing" strategy, as Gazprom has been taking steps to adjust its tactics in a number of directions, albeit mainly in response to, rather than in anticipation of, commercial reality. As discussed above, the company is developing a new pipeline export strategy, and although it is still at an evolutionary stage at least one element of it, Turkish Stream, appears commercially logical as it focuses new infrastructure on a growing gas market with the potential for increased export volumes. Furthermore,

\footnotetext{
244 Bloomberg, 28 May 2015, "Gazprom retreats on Europe export outlook as Russian ADRs drop"

245 Mitrova, T. in Henderson \& Pirani (2014), Chapter 1, p.7

246 CEIC, 8 Oct 2014, "Federal Budget Execution in 2014 and Targets for 2015-17"

${ }^{247}$ For example, Alexander Medvedev speech to Ministerial Gas Forum, 20 Nov 2010, "Role of Natural Gas in a Sustainable Energy Future"

${ }^{248}$ See Minyanville, 6 June 2011, "Russia's lucky earthquake: why Gazprom will profit from the Fukushima disaster"
} 

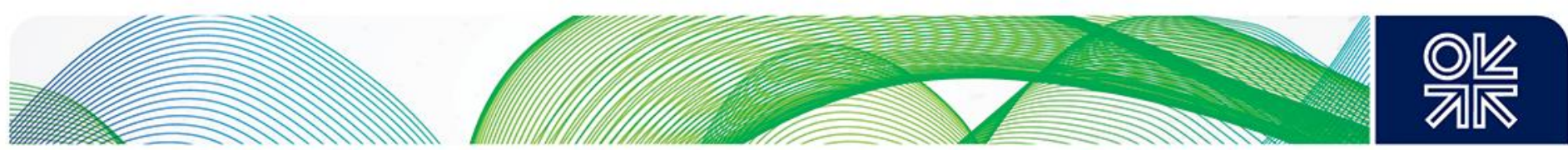

although the concept of a new hub at the Greece/Turkey border appears unrealistic at present, being both legally and commercially vague in its definition, the very mention of trading Russian gas at a hub on the European border is a step towards a new marketing position, albeit one couched to suit Russian, rather than European, goals. Along similar lines, Gazprom's recent announcement that it will auction $3 \mathrm{bcm}$ of gas for Europe for delivery to Greifswald (the landing point of Nord Stream in Germany) also points to a more market-oriented solution to problems with the EU. ${ }^{249}$ In 2009 the European Commission had demanded that Gazprom auction $3 \mathrm{bcm}$ of gas for delivery through the OPAL pipeline in order to encourage third party access, and when Gazprom refused to do this its access to the pipe was limited to $50 \%$ of the capacity. Therefore, this change of heart by Gazprom might be interpreted as a new approach to its relations with the EU, although again with a Russian twist as the gas will be auctioned in GazpromExport's offices in St. Petersburg, with the possible goal of selling Russian gas to third parties before it enters the European pipeline system and thus avoiding the problem of Gazprom dominance of the OPAL pipeline. As a result, it would appear that Gazprom and the Kremlin are prepared to countenance a new gas marketing strategy, but are introducing conditions (a new hub on the Greece/Turkey border; trading gas in St. Petersburg) that provide an element of Russian control or at least a basis for further negotiation over the terms of trade between Gazprom and its European customers.

Further evidence for this gradual shift in strategy is provided by the company's increasing willingness to talk about adapting its pricing methodology and its contractual terms. As discussed previously, the period 2010-2014 has seen Gazprom react to commercial pressures to lower prices, introduce market-related pricing for some of its gas and reduce take-or-pay levels, but at the press conferences ahead of the company's June AGM the company suggested that it could more radically alter its contract terms. According to the new head of GazpromExport, Elena Burmistrova, Gazprom is considering the removal of flexibility from some its contracts in Europe, most likely those in north-west Europe where the spot markets are most liquid and where customers can therefore satisfy changes in demand by purchasing gas on the hubs. ${ }^{250}$ Furthermore, the company is also preparing to add more gas indexation to its contracts as customers in north-west Europe are increasingly demanding the removal of the oil linkage. This strategy could certainly tie in with the company's new plan to expand the Nord Stream pipeline and the possible creation of a Baltic trading hub, and would allow it to develop a two tier marketing strategy for different regions. According to Burmistrova, customers in south and south-east Europe are still keen to retain flexibility in their contracts, meaning that supply through Turkish Stream could remain in the traditional contract structure while sales through infrastructure in the north-west are adapted to changing market demands. ${ }^{251}$

This growing ability to demonstrate flexibility in supply routes, contract terms and pricing mechanisms can benefit Gazprom, as well as its customers, in a number of ways. Firstly, of course, responding to customer requirements at a time when the political and commercial incentives are encouraging a move away from Russian gas must be a sensible strategy to retain market share in Europe. It can certainly demonstrate that Gazprom is at least willing to attempt to keep business and politics apart and is prepared to react to competition from alternative gas and energy supplies. A second benefit, though, is that a new market-based strategy can allow Gazprom to be more proactive, rather than just reactive, in its marketing efforts in Europe and ultimately in the global gas market. The company has frequently argued that the higher prices that oil-linked contracts often generate can be justified by the flexibility which it offers via the take-or-pay mechanism, ${ }^{252}$ although the logic of this argument has always been rather spurious as the premium varies every day and provides no true indicator of the value of flexibility. By removing the link between flexibility and price Gazprom can therefore set a competitive price for both, if customers wish to add flexibility to their contract agreements, or can allow customers to provide their own flexibility by signing contracts of varying lengths as well as

\footnotetext{
249 Interfax, 26 June 2015, "Gazprom to auction 3 bcm for Europe on St. Pete Exchange in September"

250 Argus FSU Energy, 11 June 2015, "Ready to revise flexibility", p.6

251 lbid.

252 Gazprom Magazine, Issue 9, "Buyers are unable and sellers are unwilling", sourced from

http://www.gazprom.com/press/reports/2014/european-market-at-a-crossroads/ on 26 June 2015
} 

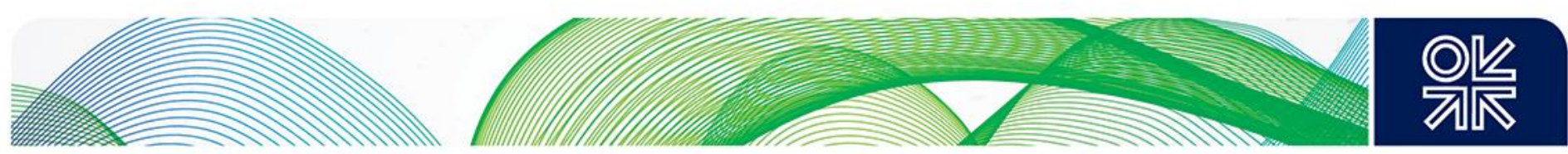

trading on the spot market. Gazprom itself can also benefit from this new methodology in its capacity as a major supplier, trading between summer and winter prices and even day-to-day as temperatures and demand change. Furthermore, by trading more actively itself it can avoid loss-making tactics such as the one adopted between September 2014 and March 2015, when attempts to restrict gas flow into Europe caused a reduction in both revenues and market share without having any significant price impact. In agreeing to change the contract terms to customers in north-west Europe Gazprom could also negotiate the right to meet some of the nominations by itself supplying gas from the hubs. As suggested in a recent paper by Rogers this "hub re-delivery" strategy would mean that it could avoid the risk of its customers purchasing gas under long-term contracts, selling any excess on the spot market, thus driving down the price, and then using this lower spot price to demand either rebates or a renegotiation of contracts terms. ${ }^{253}$ It would also allow Gazprom, as a large supplier, to have significant market power via its trading arm, with the potential to move prices.

This could provide another benefit with regard to competing with new sources of LNG. As highlighted earlier, the key for any incumbent supplier to Europe is to prevent new LNG schemes taking FID, because once capital has been committed or spent then the short-run marginal cost becomes very competitive with the cost of pipeline gas in Europe and is certainly well below the oil-linked contract price. In the case of the US, it was shown that an existing LNG scheme (i.e. post investment phase) would be incentivised to sell gas in Europe down to a price of US\$5/mmbtu at the current Henry Hub price of around US $\$ 3 / \mathrm{mmbtu}$, because the capital cost is effectively ignored. Gazprom's current pricing strategy, which is essentially reactive, offers it very little ability to create an environment which would discourage new projects, although at present this is perhaps not a major concern because low oil prices are effectively doing the job for it by keeping the gas price in Europe below the long-run marginal cost of new LNG developments. However, if the oil price starts to rise then it will be vital for Gazprom to have a mechanism to either lower prices, or more profitably to create sufficient price volatility in order to undermine the confidence of companies to invest in new LNG projects. This volatility can also provide trading opportunities for Gazprom, but its main purpose would be to disincentivise new supply options that might compete with it in Europe, and could only be achieved if Gazprom adopts a more hub-based pricing and trading strategy.

\section{Combination of evolving commercial strategy and complex political situation in Ukraine is reflected in volatile pipeline plans}

Given that Gazprom's sales strategy to Europe is in an evolutionary phase it is perhaps not surprising that its infrastructure plans are also relatively unclear, with multiple options being discussed and shifts in emphasis occurring regularly during 2014 and 2015. This situation has reflected the commercial complexities of Gazprom's price versus volume dilemma, and has been made significantly worse by political objectives concerning Ukraine. Throughout the post-Soviet period Russia and Ukraine have continually struggled to adjust from a situation in which one combined state owned significant gas reserves and a vast pipeline system stretching to the borders of Europe, to a new reality where one country controls gas supply which the other relies on while having a significant influence over its delivery to important export customers. Through the 1990s and early 2000s a debate continued between Russia and Ukraine about the fair price for gas and the cost of transit. Gazprom was always keen to see the gas price approach international levels, while Ukraine used its implicit strategic position within the Russian sphere of influence and its provision of security of transport for Russian gas exports to support its own need for low prices.

Various remedies to the pricing issue were attempted, including the direct supply of Central Asian gas to Ukraine and the use of intermediaries such as RosUkrEnergo and EuralTransGas, who provided a

${ }^{253}$ Rogers (2015), p.33 

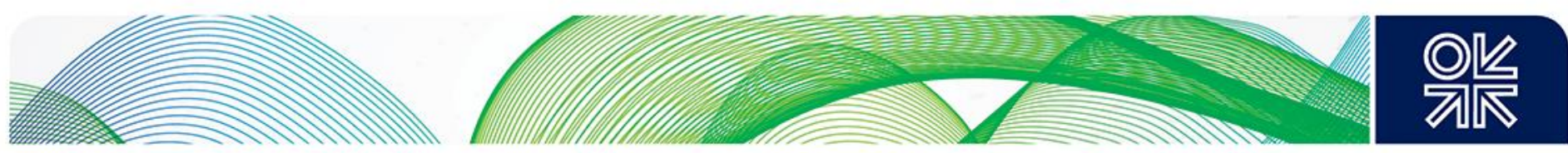

buffer for Gazprom in negotiations with Naftogas Ukrainy and the Ukrainian authorities. ${ }^{254}$ However, by the mid-2000s it had become clear that, with European gas prices rising rapidly in line with the oil price, Gazprom would need to take a direct hand in negotiations if the price discount enjoyed by Ukraine was to be reduced. ${ }^{255}$

This new Russian strategy led to the start of a series of annual negotiations (normally held in late December) where the next year's gas contract was discussed, including agreements on price and volume. Given the importance of the outcome to both countries, the debates tended to continue to the very last moment, with the underlying threat of a cessation of supply from the Russian side matched by the threat of a cut in transit of exports to Europe by Ukraine. This threat finally materialised in 2006 when, at the height of the annual disagreement, Ukraine started to syphon off gas intended for the European market, causing shortfalls in a number of countries in south-east Europe. ${ }^{256}$ Although no Gazprom customer suffered a complete cessation of supply, the interruption being very brief and hardly noticed in some countries, the impact of the incident on Russian export strategy was profound. For President Putin, who is widely regarded as the primary driver of Gazprom's key decisions, ${ }^{257}$ it confirmed his view that Russia needed to continue its tactic of removing Ukrainian transit risk, which had already started with the building of the Yamal Europe pipeline, the Blue Stream pipeline to Turkey and the plans for the Nord Stream line across the Baltic Sea. It was decided to create a new line across the Black Sea (South Stream) to finally free Russia of its reliance on a potentially disruptive neighbour. 258

This plan was re-confirmed in 2009, when a much more serious price dispute with Ukraine arose, catalysed by an initial agreement that would have seen Russian gas sold at or even higher than international prices, but which was subsequently rejected by a newly-elected Ukrainian government. ${ }^{259}$ Russia initially refused to supply gas to Ukraine unless it paid the agreed price and then, following allegations of "theft" of gas against Ukraine as it tried to replace the lost volumes, supply through the pipe was shut down, cutting off European customers for two weeks in the depths of harsh winter weather. ${ }^{260}$ However, although this dispute confirmed Russia's "transit avoidance strategy" and its plans for the South Stream pipeline across the Black Sea, it caused deep concern in the EU over the security of Russian gas supply, and raised the question of the need to diversify to alternative sources as well as the imperative to create and implement market rules to help the diversification process.

This EU concern has clearly been magnified by the crisis in East Ukraine that was catalysed by the annexation of Crimea in February 2014. In response to the perceived threat from Russia and the desire to support Ukraine the EU has used its legislative and judicial powers in a more political fashion in an attempt to counter Russia's desire to reduce gas transit through Ukraine by building alternative export infrastructure. The construction of the Yamal pipeline through Belarus and the subsequent addition of two strings of the Nord Stream offshore pipeline from North-West Russia to Germany had caused an element of controversy when they were completed in 2006 261 and 2011,262 but the main bone of contention in 2014 and 2015 has been the South Stream project, which President Putin appears to have viewed as the final piece in the jigsaw to reduce Ukraine's bargaining power over Russia. ${ }^{263}$ The main area of dispute for both Nord Stream and South Stream has been that their onshore legs need to comply with the Third Energy Package, which means that they may not be controlled by Gazprom and must offer third party access, unless an exemption is granted by

\footnotetext{
${ }^{254}$ See Pirani (2007) p.31

${ }^{255}$ For more detail on the history of Russo-Ukrainian gas relations see Pirani (2009)

256 Pirani (2009), pp.5-12

${ }^{257}$ The Guardian, 30 May 2001, "Putin takes charge of Gazprom"

258 Interfax, 22 Nov 2007, "South Stream a strategic project - Putin"

259 Pirani (2010), p.2

${ }^{260}$ New York Times, 1 Jan 2009, "Russia cuts off gas deliveries to Ukraine"

${ }^{261} \mathrm{http}: / /$ www.gazprom.com/about/production/projects/pipelines/yamal-evropa/, accessed on 10 July 2015

${ }^{262}$ http://www.gazprom.com/about/production/projects/pipelines/nord-stream/, accessed on 10 July 2015

${ }_{263}$ Natural Gas Europe, 6 Dec 2014, "Russia's South Stream decision changes regional dynamics"
} 

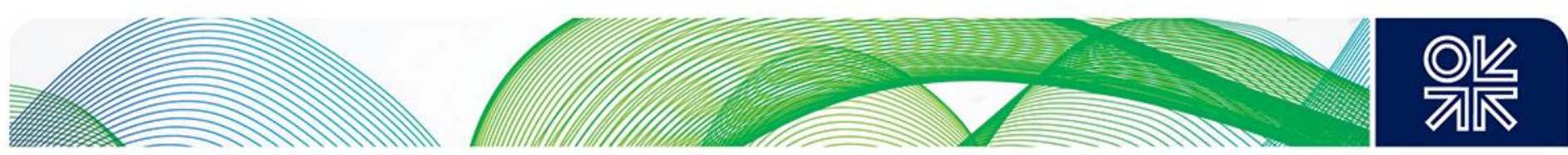

the EU. For Nord Stream the debate has surrounded the OPAL pipeline, ${ }^{264}$ which runs from the landing point in Germany into Central Europe and has a capacity of $36 \mathrm{bcma}$. When it was originally constructed Gazprom applied for an exemption from Third Party Access rules, and although the German regulator initially granted this the European Commission later reduced it to a $50 \%$ exemption, meaning that half the pipeline capacity needed to be offered to third parties. ${ }^{265}$ Furthermore, even though Gazprom is the only realistic user, the EU has to date mandated that $18 \mathrm{bcma}$ of the capacity must be kept free in case an alternative supplier appears, cutting Gazprom's ability to use its $55 \mathrm{bcma}$ Nord Stream pipe by a similar amount. A decision by the EU authorities on an appeal by Gazprom for this rule to be lifted was initially due in March 2014, but the outcome was put on hold because of the annexation of Crimea in February 2014 and the proceedings lapsed at the end of 2014. Another appeal has been made by Gazprom, but at present no resolution is in sight. ${ }^{266}$

A similar issue faced the South Stream project even as Gazprom was bringing it to the point of construction during 2014. With a total proposed capacity of 63bcma the four South Stream pipelines would have enabled Gazprom to reduce its use of transit infrastructure through Ukraine to zero given that the Ukraine system transported $62 \mathrm{bcm}$ of Russian gas to Europe in 2014. ${ }^{267}$ Under the direct instructions of Vladimir Putin, Gazprom committed significant resources towards implementing the project, spending $\$ 17$ billion on infrastructure within Russia to bring West Siberian gas to the Black Sea coast via the Russian Southern Corridor. It also formed a joint venture to construct the $\$ 14$ billion offshore section and negotiated inter-governmental agreements (IGAs) with seven European countries for the onshore line into southern and central Europe. ${ }^{268}$ However, the transit pipelines agreed under these IGAs became a key stumbling block with the European Commission, because in their initial form they did not offer third party access to alternative suppliers and therefore contravened the Third Energy Package. This led the European Commission to insist that they be renegotiated or cancelled, leaving the transit countries within the EU little choice but to comply or face infringement procedures. ${ }^{269}$ Furthermore, the EU also objected to the procurement process for the onshore pipeline in Bulgaria and started proceedings against the Bulgarian government, insisting that the pipeline construction be stopped. ${ }^{270}$

As a result the onshore section of South Stream was suspended while Gazprom raised its objections to the European Commission decision, but it soon became clear that in the midst of the Ukraine crisis no concessions were going to be made to satisfy the Russian side. Gazprom and the Kremlin therefore concluded that the pipe construction should not proceed, primarily because the Bulgarian section of the onshore pipe could not be built. A second reason was that, even if that section was completed, a situation similar to Nord Stream and OPAL could evolve, where billions of dollars were invested in a new pipeline which would then have to keep 50\% of its capacity free for non-Gazprom gas. Although Gazprom had already purchased the pipe for the first offshore string of South Stream and had done significant work on the "southern corridor" inside Russia, this new regulatory issue became the final straw which undermined the viability of a project, the economics of which had already been questioned by many commentators. ${ }^{271}$ On $1^{\text {st }}$ December 2014 Gazprom CEO Alexei Miller announced that, following a meeting of the Russian and Turkish presidents, the pipeline had been cancelled but would be replaced by an alternative line to Turkey. ${ }^{272}$

\footnotetext{
${ }^{264}$ Reuters, 3 Nov 2014, "EU delays decision on Russian access to Opal gas pipeline"

${ }^{265}$ Yafimava (2013) p.28, Note 101

266 Interfax, 15 April 2015, "Gazprom requests use of full OPAL capacity"

${ }^{267}$ Bloomberg, 14 Jan 2015, "Russia to shift Ukraine gas transit to Turkey as EU cries foul"

268 Stern et al (2015) p.2

${ }^{269}$ Stern et al (2015)p.4

${ }^{270}$ Wall Street Journal, 3 June 2014, "EU tells Bulgaria to stop work on Gazprom's South Stream"

${ }^{271}$ Financial Times, 2 Dec 2014, "Putin loses face with cancellation of pharaonic South Stream"

272 Interfax Russia and CIS oil and Gas Weekly, Nov27-Dec 3 2014, pp.11-15, "South Stream project closed over Bulgarian position, Turkey set to be Gazprom's new route south"
} 

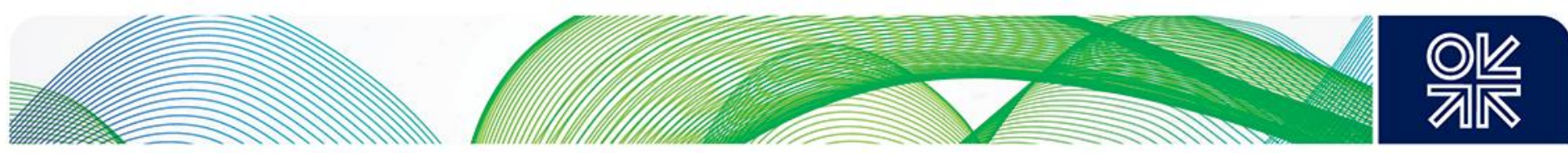

\section{Russia's export pipeline strategy demonstrates the evolving nature of Gazprom's European plans}

The announcement of the strategic switch from South Stream to Turkish Stream appeared to mark a definitive moment in Russian export strategy to Europe, both because it acknowledged that EU rules on control of and third party access to new pipeline infrastructure were legally binding and also because the new route appeared to be more commercially sensible, targeting the fastest growing gas market in Europe and Gazprom's second largest customer. However, even at the time of its unveiling the Turkish Stream project appeared to be a rushed response to a crisis (causing surprise to the Turkish side amongst others). ${ }^{273}$ Subsequent events have underlined that, although Russia and Gazprom appear committed to creating increased diversity of export routes, their plans are still very much at an evolutionary stage.

The potential future capacity of Gazprom's export pipelines to Europe is shown in Figure 24 below. It is clear that the current capacity of existing pipelines (assuming capacity of $142 \mathrm{bcm}$ through Ukraine) $)^{274}$ already provides a surplus of almost $100 \mathrm{bcm}$ over Gazprom's exports to Europe in 2014, while the sum of all future planned expansions could add a further $150 \mathrm{bcm}$ of capacity, taking the total to just under $400 \mathrm{bcm}$. These future plans include not only Turkish Stream but also the possible doubling of capacity in the Nord Stream pipeline announced at the St Petersburg Forum in June 2015 and reiterated in Vladivostok in September 2015,275 as well as the long-discussed addition of a second line to the Yamal-Europe pipeline. Although this potentially dramatic increase in export capacity and the apparent desire of Gazprom and the Kremlin to discuss multiple pipeline options does raise obvious questions about the viability and credibility of the Russian strategy, it nevertheless also leads to some significant conclusions concerning the drivers of company and government policy.

Firstly, Russia's pipeline plans underline its desire to reduce Ukraine's bargaining power significantly by opening up other export routes, or at least threatening to do so. ${ }^{276} \mathrm{It}$ is clearly valid to question whether it will ever be practically possible, both operationally and legally, to reduce Ukraine transit to Gazprom's target of zero, as even President Putin now seems to have concluded that Gazprom must consider continuing transit after the expiry of its current contract in 2019. ${ }^{277}$ One must nevertheless acknowledge the firm Russian objective and its potential consequences.

\footnotetext{
273 The Moscow Times, 21 Jan 2015, "Russia's new Turkish Stream gas strategy more bark than bite"

274 Naftogaz of Ukraine at http://www.naftogaz.com/www/3/nakweben.nst/0/3375A8575C8884D0C22571010035B9D2, accessed on 10 July 2015. This is a figure for total capacity, although only 100-120bcma may be practically usable in 2015 , given maintenance and upgrading requirements

${ }^{275}$ Reuters, 18 June 2015, "Russia's Gazprom to expand Nord Stream gas pipeline with E.ON, Shell, OMV"

276 Interfax, 9 June 2015, "Gazprom: gas transit through Ukraine to end after 2019, come what may"

277 Kyiv Post, 26 June 2015, "Putin orders talks held with Ukraine on gas transit after 2019"
} 

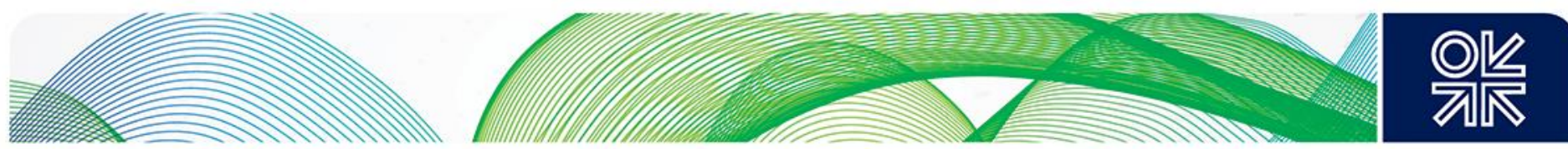

Figure 24: Gazprom current and proposed pipeline capacity to Europe

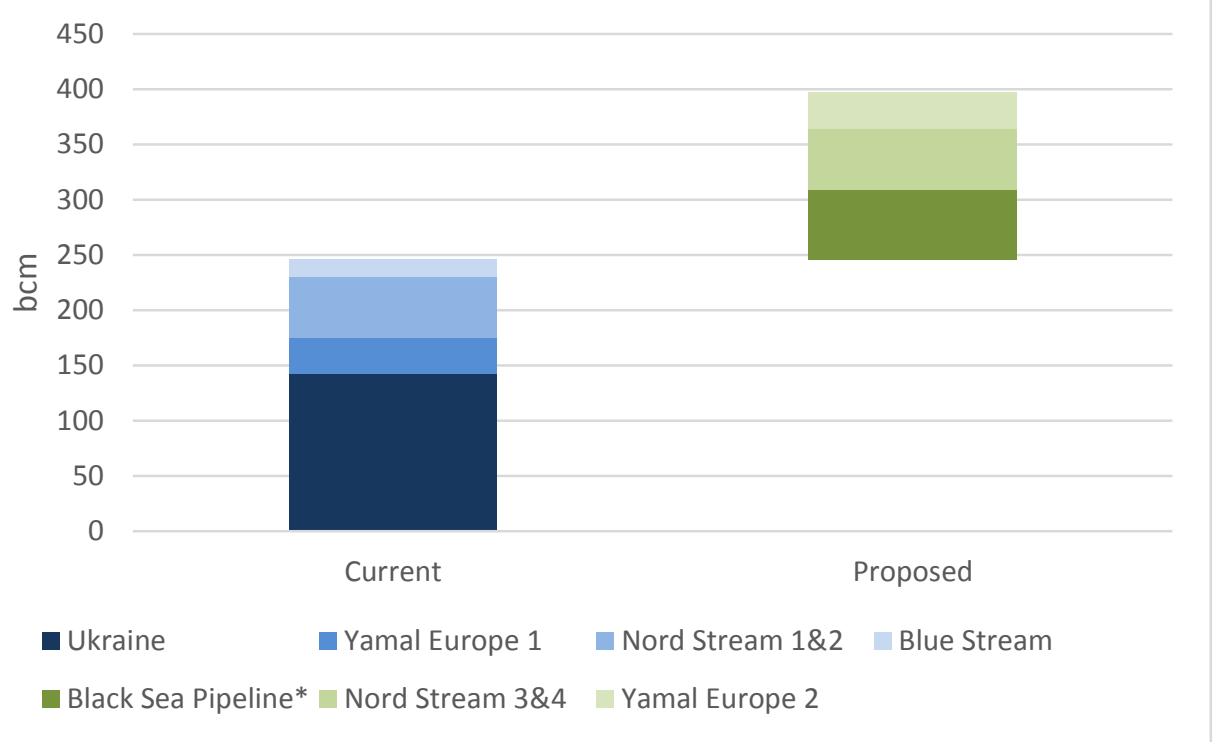

Source: Gazprom, Naftogaz

Secondly, the decision to switch South Stream to Turkish Stream would appear to acknowledge the ability of the European Commission to enforce the Third Energy Package and a new willingness, albeit reluctant, of Gazprom and Russia to abide by it. Indeed, in subsequent statements Alexei Miller has been keen to point out that his company's new strategy "will strictly adhere to the Third Energy Package."278

Thirdly, the Turkish Stream announcement was also accompanied by a statement that, while some of the gas through the proposed $63 \mathrm{bcm}$ pipe would remain in Turkey to satisfy growing demand there, the majority would be available for onward transit into Europe via a new "hub" at the Turkey-Greece border. ${ }^{279}$ Although Gazprom's concept of a hub would not appear to match that of the European Commission, and the creation of a brand new entry point for Russian gas is clearly fraught with issues for its customers, nevertheless the mere fact that Gazprom is now prepared to countenance discussion of its gas being traded in a hub-based system (albeit apparently on its own terms) marks a significant change in emphasis for the company.

Fourthly, Gazprom's willingness to build new pipeline infrastructure to Europe underlines its belief that over the long-term it will be selling more, rather than less, gas to the continent, despite the impact of the Ukraine crisis and sanctions. This point has been underlined by former head of GazpromExport Alexander Medvedev on a number of occasions, ${ }^{280}$ and is a consistent theme in the company's Investor Day strategy presentations. ${ }^{281}$

Nevertheless, the indecision over which routes to pursue, the constant changing of tactics and the adoption of plans such as the Greek pipeline which seem more related to politics than economics, point to a continued uncertainty over the exact outcome. As a result, Gazprom's emerging strategy appears to be an attempt to create alternative options that can allow it to find some compromise between asserting its confidence in the irreplaceability of its gas in Europe and the need to adapt to new European market rules in order to underpin its long-term prospects, while also allowing it to improvise in order to gain political and commercial advantage where possible. However, given the

\footnotetext{
${ }^{278}$ Alexei Miller speech at conference "Europe and Eurasia: Towards the New Model of Energy Security", available at http://www.gazprom.com/press/miller-journal/029076/, accessed on 16 June 2015

${ }^{279}$ Financial Times, 7 May 2015, "Gazprom announces deal with Ankara to build Black Sea pipeline"

${ }^{280}$ Reuters, 3 Mar 2014, "Gazprom says Europe to depend more on Russian gas in years to come"

281 Gazprom Investor Day 2015, Feb 2015 in Hong Kong and Singapore, slide 11
} 

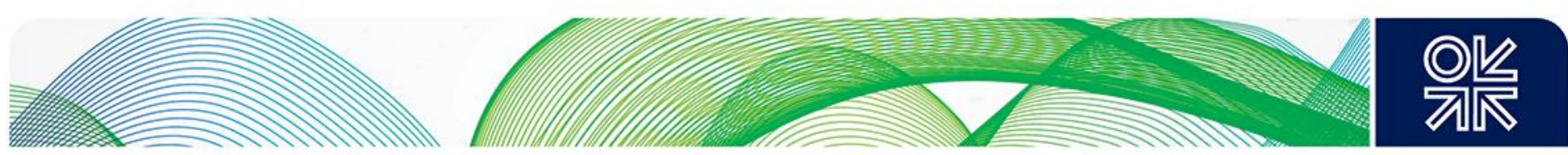

level of uncertainty about both future gas demand in Europe and the level of Russian imports that will be needed and/or wanted to fill any supply gap, it is clearly valid to question the likely realistic result of Gazprom's pipeline plans.

\section{Given the uncertainty, what are the realistic options for Gazprom's export pipelines?}

As highlighted in Figure 24 above, if Gazprom constructed all the new pipelines that it has mentioned to date, including four strings of Turkish Stream $(63 \mathrm{bcm}), 2$ new strings of Nord Stream $(55 \mathrm{bcm})$ and even an expansion of Yamal Europe $(33 \mathrm{bcm})$ then its total export capacity to Europe would reach $400 \mathrm{bcm}$. The only plausible logic for this expansion would be the complete avoidance of Ukraine transit, but even this would only make sense in the maximum Russian export case we outline above, which sees possible exports of $260 \mathrm{bcm}$ by 2030 (see Figure 20). However, as we now know that on a commercial basis Gazprom is financially constrained and also that on a political basis President Putin has conceded that complete avoidance of Ukraine transit is unlikely to be possible (at least in the medium term), then it would appear obvious that not all the proposed lines will be built. Indeed the real question is will any of them be built on their currently proposed timetables?

Perhaps the easiest option to dismiss is the expansion of the Yamal Europe pipeline (known as Yamal-2), which was proposed by Gazprom in 2013 and led to the signing of a memorandum of understanding with Polish company Europol Gaz. ${ }^{282}$ Gazprom had expected to construct the pipeline itself, but was informed by the Polish Prime Minister Donald Tusk that if any construction was to be done it would be by a Polish company, and that any decisions on a new pipeline would be taken by the Polish government alone. ${ }^{283}$ Given Mr. Tusk's subsequent opposition to Russian gas in his new position as President of the European Council, where he has suggested the creation of an Energy Union to encourage diversification away from Russian gas, it seems highly unlikely that Gazprom would be allowed by Poland to proceed with Yamal-2 in the foreseeable future. Indeed the company appears to have accepted this outcome, cancelling preliminary orders for steel to manufacture of the pipe and going silent on the future of the project since $2014 .{ }^{284}$

Instead Gazprom's focus has switched to offshore pipelines in the Black and Baltic Seas, with the former creating the most short-term interest. Russia's decision to cancel the South Stream Project, which was planned to land in Bulgaria, has been discussed above, with the switch to Turkish Stream offering some apparent commercial logic (see Map 2). However, even as the initial announcement was made the Turkish authorities appeared first surprised by the decision and then determined to make the most of it by demanding gas price concessions for effectively acting as a transit country for Russian gas to the proposed "Greece-Turkey" hub. Having initially agreed a $10.25 \%$ discount in March 2015, ${ }^{285}$ it would now seem that the Turks are demanding more as the vital inter-governmental agreement that is needed before any construction can begin was still waiting to be signed in August 2015. ${ }^{286}$ This delay also appears to have been catalysed by a series of political issues that have strained relations between the two countries and could undermine the signing of a strategic gas deal. Firstly in April 2015 President Putin recognised the killing of Armenians by Ottoman Turks in 1915 as genocide, much to the annoyance of Turkish President Tayyip Erdogan. Secondly, the results of the Turkish elections in June 2015 have undermined the position of Erdogan's AKP party and have meant not only that a new election has had to be called for $1^{\text {st }}$ November $2015,{ }^{287}$ delaying any possible agreement on Turkish Stream, but also that the country's energy policy could eventually shift away

\footnotetext{
282 RT, 8 April 2013, "Poland gives Gazprom cold shoulder in pipeline deal"

283 Business New Europe, 5 April 2013, "Poland slams Russia's Yamal-Europe gas pipeline plan"

${ }^{284}$ WBJ, 6 Feb 2014, "Gazprom drops Yamal-Europe 2 expansion"

${ }^{285}$ RT Business, 18 Mar 2015, "Moscow and Ankara agree $10.25 \%$ gas discount for Turkey"

286 Daily Sabah, 4 Aug 2015, "Turkey waiting for Russia to sign natural gas discount deal"

287 BBC, 21 Aug 2015, "Turkey to vote in November snap poll"
} 

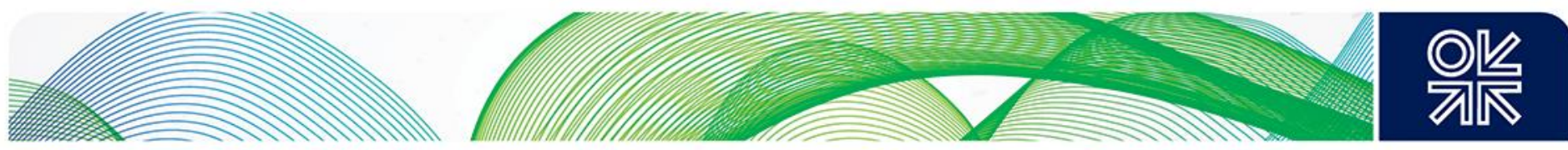

from closer Russian ties towards the EU, again threatening the Turkish Stream pipeline. ${ }^{288}$ Thirdly, the war in Syria has strained ties between Russia, which supports the Assad regime, and Turkey, which opposes it and is now taking military action in the country, leading to criticism of the Turkish government by leading Russian officials. ${ }^{289}$ Finally, statements from Turkish officials have indicated that, although they can see some benefit from Turkish Stream, their current priority is the successful completion of the TANAP project from Azerbaijan, which is seen as an important diversification project by the EU and is also supported by the US. 290

Furthermore, even if the project does move ahead it is unclear exactly how much capacity will be built. Gazprom has already purchased the pipe for a first string of South Stream, which could now be used to build a first $15.5 \mathrm{bcm}$ line to Turkey. Conveniently this would divert all Russian gas currently passing through Ukraine bound for Turkey, thus providing increased security of supply to Turkey. It appears most likely that this line could be constructed in the next two to three years, although Gazprom's target of 2016 seems optimistic given delays to date. Thereafter, the prospects for another three lines seem much less clear. A second line, for which Gazprom has already ordered the pipe due to its original plans for South Stream, ${ }^{291}$ could provide gas for the Balkan countries, if flows through the Balkan pipeline which currently carries gas to Turkey are reversed, and so this could again provide Ukraine transit diversification for South-East Europe. However, the third and fourth lines, which would carry Russian gas to the Greece-Turkey border, are much more speculative, as any gas arriving there would require new infrastructure to be built into the EU to send gas to the delivery points specified in the Russian gas export contracts. Russia has been discussing the potential for a pipeline to be built across Greece with the country's authorities, although this negotiation may have been as much driven by political gamesmanship as commercial reality, ${ }^{292}$ and various plans have also been discussed to move potential supplies on into south-east Europe. ${ }^{293}$ However, as discussed in a forthcoming paper by Pirani and Yafimava (2015) agreement on these issues is far from being reached, and as a result these two extra Turkish Stream lines are very unlikely to be built before $2020 .{ }^{294}$

\footnotetext{
${ }^{288}$ International Business Times, 5 June 2015, "Turkish election could jeopardize Erdogan's energy deals, alter relationship with EU and Russia"

289 Today's Zaman, 29 May 2015, "Russian FM Lavrov criticises Turkey, US for rebel training in Syria"

${ }^{290}$ Natural Gas Europe, 6 July 2015, "Difficulties ahead for Turkish Stream"

291 Offshore Energy Today, 15 April 2014, "South Stream's offshore section pipe No.1 produced"

292 Wall Street Journal, 19 June 2015, "Greece, Russia strike preliminary gas pipeline deal"

${ }^{293}$ For example the Tesla pipeline (http://www.euractiv.com/topics/tesla-pipeline) and the Eastring pipeline

(http://www.eastring.eu/)

${ }_{294}^{29}$ Pirani and Yafimava (2015)
} 

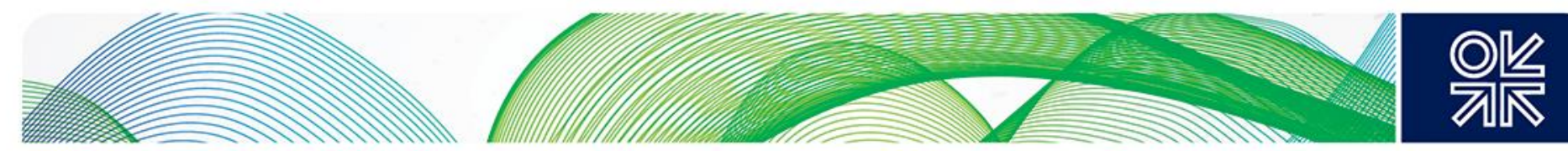

\section{Map 2: Turkish Stream and South Stream pipeline routes}

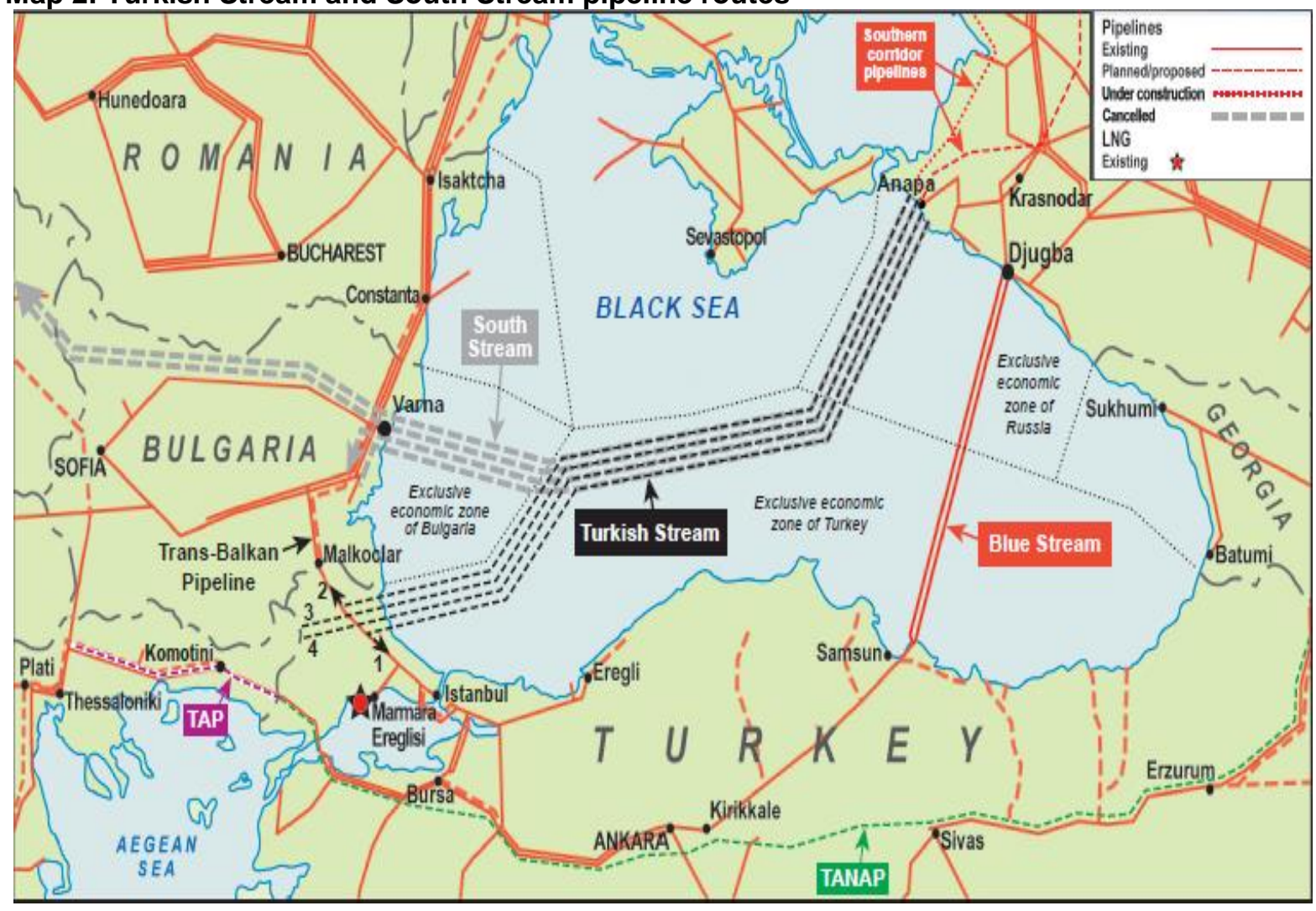

Source: OIES

Increasing uncertainty over the future of Turkish Stream has prompted Gazprom to resurrect its 2009 plan to expand the Nord Stream pipeline via the addition of another two lines ( 3 and 4 ) with an extra $55 \mathrm{bcm}$ of capacity. The new pipelines would be built by a consortium including Gazprom plus Shell, E.ON, OMV, Wintershall and Engie, but its announcement at the St Petersburg International Economic Forum in June 2015 came as a surprise and suggests that it was something of a last minute Russian reaction to its problems with the pipeline to Turkey. 295 Indeed sources in Moscow have suggested that the consortium of foreign companies was put together at late notice, and therefore the future of the project remains under discussion. A major issue will clearly be negotiation with the EU concerning transport of any new gas across the continent, given the problems with the current Nord Stream gas being moved through the OPAL pipeline, and opposition has already been heard from some member countries. ${ }^{296}$ As a result, although an expansion of Nord Stream appears logical given the location of the majority of Gazprom's major customers in Europe, any future progress is likely to be relatively slow as it will have to rely on the smoothing of political relations between the EU and Russia as much as on the commercial logic of the new infrastructure.

\footnotetext{
${ }^{295}$ Reuters, 18 June 2015, "Russia's Gazprom to expand Nord Stream gas pipeline with E.ON, Shell, OMV" 296 The Lithuania Tribune, 9 July 2015, "Nord Stream expansion to do great harm to Ukraine"
} 

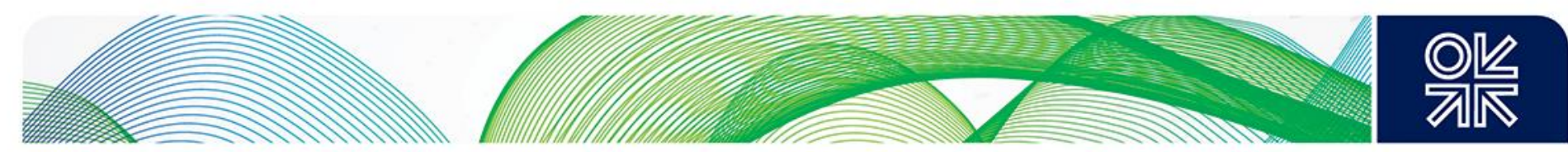

Map 3: Nord Stream pipeline

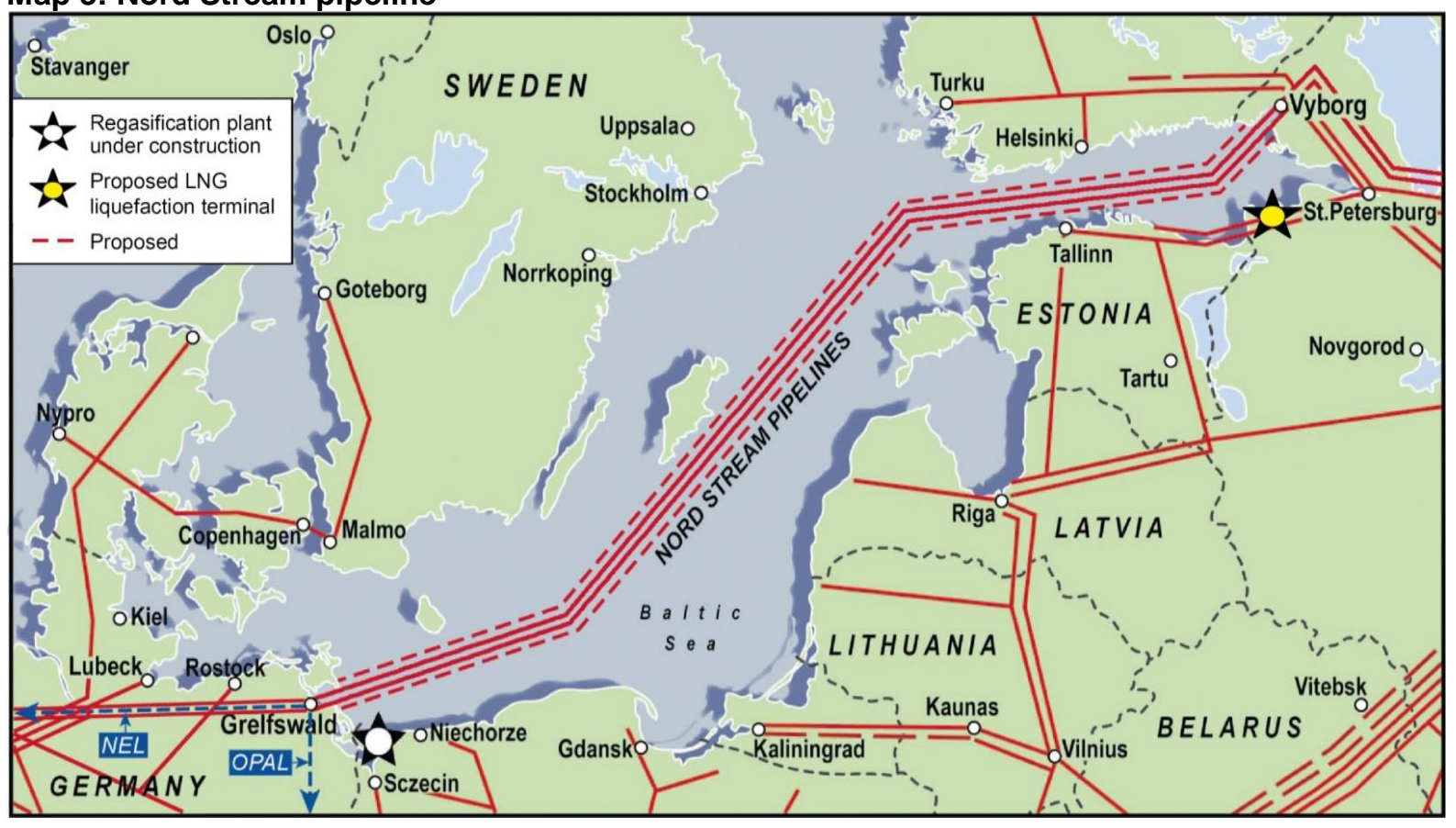

Source: OIES

The potential difficulties with all three of Gazprom's proposed alternatives to Ukraine transit pipelines are compounded both by the existing export contracts which the company has with customers in Europe and by the commitments it has made to use transit pipes in countries bordering Ukraine. The export contracts specify delivery points, many of which can only be reached via Ukraine, meaning that they would either have to be renegotiated (with potentially broader consequences for Gazprom) or that new infrastructure would have to be built (unlikely in the short term). Furthermore, even if the gas did flow, Gazprom has ship-or-pay commitments with companies such as Eustream in Slovakia which mean that it would have to continue paying for gas shipment even if no volumes flow, costing it many millions of euros each year. ${ }^{297}$ The combination of all these issues has led to the realisation in Moscow that the Ukrainian pipeline system will continue to be an indispensable part of the Russian export strategy beyond the end of the current contract in 2019, which is why President Putin has ordered Gazprom CEO Alexey Miller to open negotiations on a continuation of the current trade links. ${ }^{298}$

This apparent partial volte-face on Russia's Ukraine transit avoidance strategy would seem to epitomise the ad hoc nature of the country's gas export strategy, with solutions being sought to shortterm problems, before new problems emerge which demand yet more answers. South Stream was an initial answer to the Ukraine transit issue, but when it became untenable under EU legislation Turkish Stream appeared in a surprise announcement. As Turkish Stream ran into trouble so Nord Stream expansion emerged in another last minute deal, and when the credibility of the whole transit avoidance strategy was called into question the Russian president ordered a re-think and a new discussion with Ukraine, completing the circle. As a result, forecasting the ultimate outcome is fraught with difficulty, although as of August 2015 the authors' best estimate would be that some part of Turkish Stream will be built by 2020 (certainly one and perhaps two lines), while Ukraine transit may fall by an equivalent amount $(15.5-31 \mathrm{bcm})$ but will still be an integral part of the Russian gas export system. Nord Stream 3 and 4 could disturb this picture, but as EU approval for any new onshore

\footnotetext{
297 Bloomberg, 5 June 2015, "Gas transit deal shows cost to Russia of by-passing Ukraine"

298 Kyiv Post, 26 June 2015, "Putin orders talks held with Ukraine on gas transit after 2019"
} 

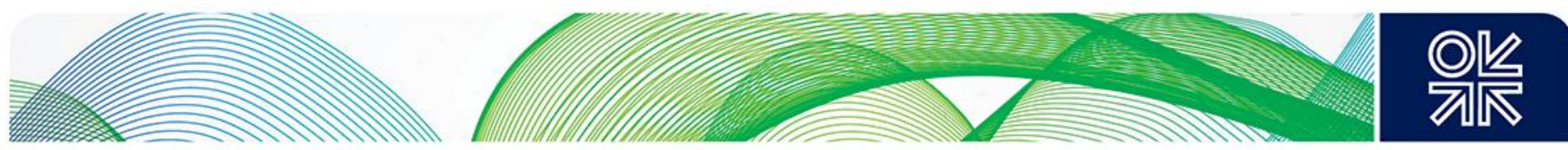

capacity is only likely once the Ukraine conflict has reached some form of mutually agreeable outcome it is certainly possible that politics could delay the project beyond its currently planned timetable.

Table 7 below attempts to summarise this from the perspective of transit through Ukraine, looking at a matrix of outcomes involving Nord Stream expansion and Turkish Stream capacity (taking the latter as a proxy for a Black Sea export pipeline, despite our reservations over the current state of the relationship between Turkey and Russia). As can be seen, the likelihood of Ukraine transit being reduced to zero at any time in the near future is relatively low (and certainly not before the early 2020s), as it would require either the construction of all four lines of Turkish Stream or two lines of Turkish Stream plus at least one new Nord Stream line. A more likely outcome is therefore that between 20 and $30 \mathrm{bcm}$ of gas will continue to flow through the Ukraine system for the foreseeable future, with Russia using the increased leverage offered by a new Black Sea route to ensure competitive tariffs and improved security of supply.

\section{Table 7: Comparison of scenarios for Russian export pipeline expansion to Europe}

\begin{tabular}{|c|c|c|c|}
\hline & No Nord Stream expansion & Nord Stream-3 & Nord Stream-3 and 4 \\
\hline No Turkish Stream & $\begin{array}{l}\text { Transit through Ukraine } \\
\sim 60 \mathrm{bcma}\end{array}$ & $\begin{array}{l}\text { Transit through Ukraine } \\
\sim 30 \mathrm{bcma}\end{array}$ & $\begin{array}{c}\text { No transit through Ukraine } \\
\text { if NS is completely utilized, } \\
\text { otherwise limited Ukraine } \\
\text { transit }\end{array}$ \\
\hline Turkish Stream 1 & $\begin{array}{l}\text { Transit through Ukraine } \\
\qquad \sim 45 \mathrm{bcma}\end{array}$ & $\begin{array}{l}\text { Transit through Ukraine } \\
\qquad \sim 20 \mathrm{bcma}\end{array}$ & No transit through Ukraine \\
\hline Turkish Stream 1 and 2 & $\begin{array}{l}\text { Transit through Ukraine } \\
\sim 30 \mathrm{bcma}\end{array}$ & $\begin{array}{l}\text { No transit through Ukraine } \\
\text { if NS is fully used, otherwise } \\
\text { limited Ukraine transit }\end{array}$ & No transit through Ukraine \\
\hline Turkish Stream 1,2,3 & $\begin{array}{l}\text { Transit through Ukraine } \\
\sim 10-15 \text { bcma }\end{array}$ & No transit through Ukraine & No transit through Ukraine \\
\hline Turkish Stream 1,2,3,4 & No transit through Ukraine & No transit through Ukraine & No transit through Ukraine \\
\hline
\end{tabular}

Source: Author's estimates

Russia's LNG strategy is also in a state of flux, with Novatek set to replace Gazprom as the country's leading player

The relative confusion over Russia's pipeline plans underlines the uncertainty over Russia's gas export strategy as well as the problems being faced by Gazprom as a company as it gradually develops a new export strategy. A further element of risk is added by the company's own plans in Asia and Russia's overall strategy to participate in the LNG market globally, which could have an increasing impact on the European market and again argue for a more market-oriented approach. As far as Gazprom's Asian pipelines are concerned, the company has argued that its pricing strategy in the region can remain oil-linked because that is the prevailing methodology, but it is becoming clear not only that this may not be the case for much longer, ${ }^{299}$ but also that, because of the impending oversupply of LNG, any new Russian pipeline gas sold into China could have a knock-on effect as LNG gets displaced and re-directed to Europe. As a result, Gazprom's own activities in China can potentially undermine not only its business in Europe, especially if it does manage to sign two pipeline

${ }^{299}$ See Stern J. and Rogers H. (2014a) for a detailed discussion 

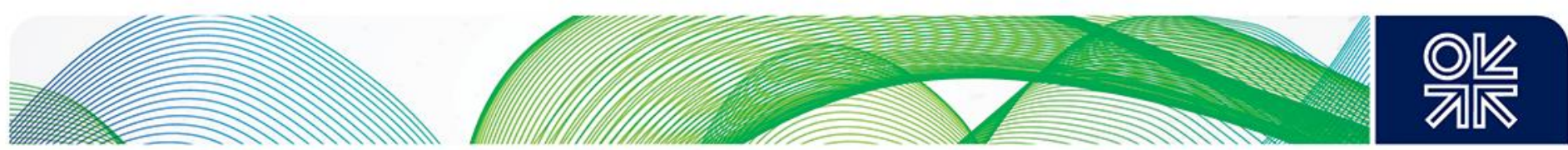

deals with CNPC, but also its plans, as well as those of its emerging competitors Novatek and Rosneft, to expand into the LNG market.

Gazprom's LNG history stretches back to the early 2000s when it first began to make plans for the development of the Shtokman field in the Barents Sea, from where LNG was due to be sent to the US market. ${ }^{300}$ Unfortunately this project was postponed due to a combination of disagreement among the partners concerning the best technological and operational solutions and the dramatic change in the US import requirement caused by the shale gas revolution there. This latter factor also undermined Gazprom's other west-facing scheme at that time, Baltic LNG, which failed to attract sufficient foreign investor interest. Gazprom's one LNG success, in fact, has been in the East where it purchased a $50 \%$ stake in the Sakhalin 2 project in 2006, ${ }^{301}$ although again foreign investor participation has been crucial as a Shell-led consortium (Sakhalin Energy) has led the field development. Indeed a fundamental issue with LNG in Russia is that all the currently available liquefaction technology is manufactured in the US or Europe, and no Russian company has any significant experience of LNG development, meaning that foreign participation is currently a pre-requisite for any scheme to proceed.

Sakhalin 2 came online in 2009 and currently produces $10.5 \mathrm{mtpa}$ of LNG which is sold into the Asian market, predominantly to Japan. ${ }^{302}$ The success of the project, and the clear need for LNG in Asia, where the three main markets (Japan, South Korea and Taiwan) are effectively "gas islands", led Gazprom to refocus its LNG plans on the East, in tandem with the development of its Eastern Gas Programme and the plan to export gas to China. LNG could both provide access to new markets for Russian gas and act as a bargaining chip in negotiations with China over pipeline exports, proving that Gazprom had alternative outlets for its product. Indeed Russia, via Rosneft and Transneft, had adopted the same tactic when expanding oil exports to China, developing a port on the Pacific Coast near Vladivostok as well as a pipeline to China in order to provide a diversity of markets. ${ }^{303}$ Gazprom's plan was to adopt the same scheme, building an LNG plant at Vladivostok as well as a gas pipeline into North-East China (see Map 1).

However, the economic and commercial foundations for constructing an LNG plant more than 3,000 kilometres from its gas source were always going to be challenging irrespective of the technical issues. The estimated breakeven cost of supply from the proposed Vladivostok LNG project was significantly higher than other competing schemes, and customers were reluctant to commit to LNG supply from a development with uncertain prospects. ${ }^{304}$ When these problems were combined with the fact that Gazprom's overall negotiations with China were proceeding relatively slowly, the door was opened to a challenge from third parties which duly materialised as Rosneft and Novatek presented their own LNG projects for consideration. The main obstacle to their development was Gazprom's monopoly over all Russian gas exports, but Rosneft's lobbying power, led by its influential CEO Igor Sechin, succeeded in catalysing a new law (passed in December 2013) which gave export access to two specific types of LNG project. Firstly, those with an LNG plan written into the license agreement (covering Novatek's Yamal LNG project) ${ }^{305}$ could export their output, and secondly projects involving an offshore gas field operated by a state-controlled company (covering Rosneft's proposed Sakhalin 1 LNG scheme, called Far East LNG) ${ }^{306}$ could also sell gas overseas in liquefied form. ${ }^{307}$

\footnotetext{
300 Mitrova (2013), p.15

${ }^{301}$ New York Times, 6 Dec 2006, "Shell cedes control of Sakhalin 2 to Gazprom"

302 Reuters, 6 April 2009, "Japan's first Sakhalin 2 LNG arrives from Russia”

${ }^{303}$ Henderson (2011a), p.11

${ }^{304}$ Henderson \& Pirani (2014), p.239

305 Yamal LNG is a 3-train 16.5mtpa LNG project being developed by Novatek (60\%), Total $(20 \%)$ and CNPC $(20 \%)$ on the north-east coast of the Yamal peninsula, based on production from the South Tambey field. First LNG is expected in 2017. For full details see Novatek presentation to investors, 2 Dec 2014, "Harnessing the Energy of the Far North", slides 15-24

${ }^{306}$ Rosneft's Far East LNG scheme is at an earlier stage than Yamal LNG, but is planned to produce 5mtpa (possibly rising to 10mtpa) from 2020 based on gas from the Sakhalin 1 fields. The Sakhalin 1 partners, including ExxonMobil, are expected to be involved in the project, but plans are currently being delayed by a dispute with Gazprom over pipeline access rights on Sakhalin
} 

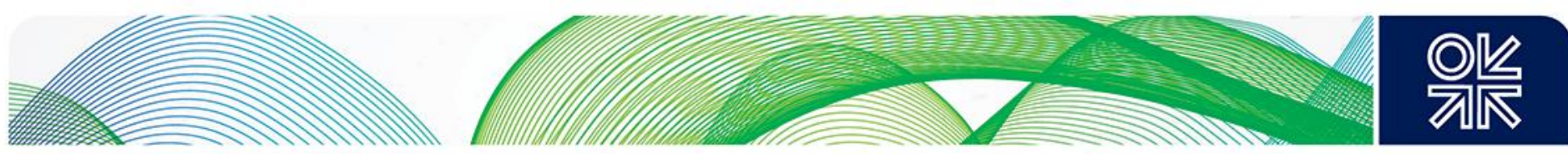

However, subsequent to this law being passed, a number of factors have combined to undermine Russia's LNG plans.

- Firstly the imposition of sanctions by US and EU governments has affected the ability of Gazprom, Novatek and Rosneft to raise financing for their planned projects. ${ }^{308}$

- Secondly, the sharp fall in the oil price has affected the economic prospects for all LNG projects, especially high cost ones such as Far East LNG and Vladivostok LNG, and has further undermined the ability of Russian companies to fund development costs. ${ }^{309}$

- Thirdly, concern among consumers that the sanctions regime could ultimately extend to LNG technology has put off possible partners for the projects.

- Fourthly, some customers have been reluctant to commit to buying LNG from Russia under longterm contracts at a time of geo-political uncertainty, when relations with the US remain a priority for many LNG consuming countries and there is a desire to be seen to be supporting, not undermining, the sanctions regime.

- And finally the US authorities have taken the relatively unprecedented step of imposing sanctions on a specific gas field in the Far East of Russia, South Kirinskoye in the Sakhalin 3 licence, in order to undermine gas supply to a potential expansion of the Sakhalin 2 project.

As a result all of the projects listed in Table 8, which includes LNG schemes in the east and the west of the country, are now faced with significant issues that could cause their delay, postponement or cancellation.

Island, which has caused a re-location of the LNG facilities. A new court ruling in September 2015 has ruled in Rosneft's favour concerning pipeline access, but it remains to be seen how this will affect Rosneft's plans for its LNG strategy.

${ }^{307}$ Mitrova (2013) p.3

${ }^{308}$ Fitch Ratings, 11 Mar 2015, "Sanctions a bigger threat to Russian oil than weak prices"

${ }^{309}$ Financial Times, 13 Nov 2014, "Oil's dive set to transform LNG market" 

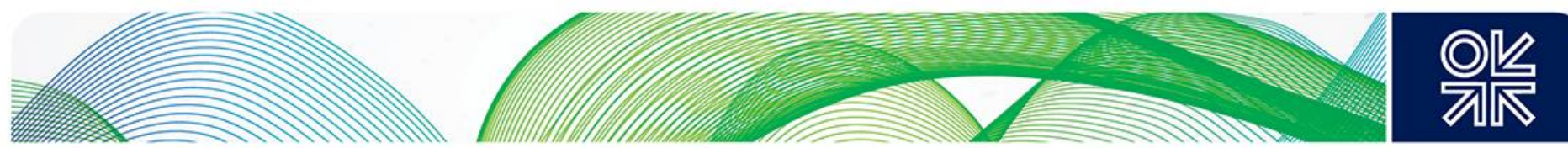

Table 8: LNG projects in Russia (Existing and potential)

\begin{tabular}{|c|c|c|c|c|}
\hline & Russian Operator & Partners & $\begin{array}{c}\text { Volume } \\
\text { (mtpa) }\end{array}$ & Status \\
\hline Sakhalin 2 Existing & Gazprom & $\begin{array}{l}\text { Shell, Mitsubishi, } \\
\text { Mitsui }\end{array}$ & 10 & Producing since 2009 \\
\hline Sakhalin 2 Expansion & Gazprom & $\begin{array}{l}\text { Shell, Mitsubishi, } \\
\text { Mitsui }\end{array}$ & 5 & Possible FID in 2016 \\
\hline Yamal LNG & Novatek & Total, CNPC & 16.5 & $\begin{array}{l}\text { Under construction; first } \\
\text { output planned 2017/18 }\end{array}$ \\
\hline Baltic LNG & Gazprom & & 10 & $\begin{array}{l}\text { Start-up planned for } 2020 \text {, } \\
\text { but still in planning stages }\end{array}$ \\
\hline $\begin{array}{l}\text { Far East LNG (Sakhalin } \\
\text { 1) }\end{array}$ & Rosneft & Exxon, Sodeco, ONGC & $5-10$ & $\begin{array}{l}\text { Initially planned for } 2019 \text {, } \\
\text { but now postponed to early } \\
2020 \text { s }\end{array}$ \\
\hline Vladivostok LNG & Gazprom & & $10-15$ & Postponed until beyond 2020 \\
\hline Arctic LNG & Novatek & & 16.5 & $\begin{array}{l}\text { New LNG concept based on } \\
\text { Gydan peninsula fields. } \\
\text { Possible start-up in mid- } \\
\text { 2020s }\end{array}$ \\
\hline Pechora LNG & Rosneft & Alltech & 4 & $\begin{array}{l}\text { Concept outlined, but no } \\
\text { firm plans yet }\end{array}$ \\
\hline Shtokman (Phase 1) & Gazprom & Total, Statoil & 15 & Postponed indefinitely \\
\hline
\end{tabular}

Source: Gazprom, Novatek, Rosneft, Mitrova (2013)

Plans to add a third train to the Sakhalin 2 project, which appears to be Russia and Gazprom's most logical next LNG project, have been under discussion for a number of years, ${ }^{310}$ but the continuing problem has been gas supply as the Sakhalin 2 license does not have sufficient reserves to supply an expanded liquefaction plant. Furthermore the timing of the development of Gazprom's Sakhalin 3 fields, which contain over $700 \mathrm{bcm}$ of gas, ${ }^{311}$ is now very uncertain while the likelihood of gas being supplied from Rosneft's Sakhalin 1 project is low because of political issues, ${ }^{312}$ (although Rosneft CEO Igor Sechin has stated in September 2015 that he may be prepared to consider a sale if the Sakhalin 1 partners are offered a netback price by Gazprom). ${ }^{313}$ Gazprom has signed a commitment to supply gas to a third train at Sakhalin 2,314 but the development of the Kirinskoye and South Kirinskoye fields at Sakhalin 3 is complicated by the presence of oil, ${ }^{315}$ the relatively deep water in which part of the South Kirinskoye field lies, Gazprom's lack of experience in offshore developments and the addition of the fields to the US sanctions list. ${ }^{316}$ As a result, plans which had been announced for the Sakhalin 2 partners to take a similar share in the Sakhalin 3 development in order to facilitate the development of the gas reserves must now be in doubt, again undermining the Sakhalin 2 expansion plans. ${ }^{317}$

Gas supply doubts have also undermined Gazprom's Vladivostok LNG scheme, with the original concept of gas deliveries from East Siberia now having been shelved, while the alternative concept of gas from Sakhalin also appears to have been dropped as the company re-focuses its efforts on

\footnotetext{
${ }^{110}$ Interfax, 30 Jan 2012, "Sakhalin 2 operator estimates LNG expansion in 2017-18"

${ }^{311}$ Interfax, 17 Aug 2015, "Gazprom puts Yuzhno-Kirinskoye reserves at 706bcm, 111 mln tonnes of condensate"

312 The Diplomat, 24 July 2015, "Squabbling energy oligarchs threaten Moscow's LNG plans"

${ }^{313}$ Vedomosti, 4 Sept 2015, "Rosneft prepared to sell Sakhalin 1 gas to Gazprom"

314 The Moscow Times, 18 June 2015, "Russia's Gazprom, Shell agree to expand Sakhalin 2 project"

315 Platts, 3 June 2013, "Gazprom says South Kirinskoye field reserves comparable to Shtokman"

${ }^{316}$ Reuters, 10 Aug 2015, "US sanctions put Gazprom-Shell alliance plans in jeopardy"

317 Reuters, 18 June 2015, "Gazprom, Shell agree to expand Sakhalin 2"
} 

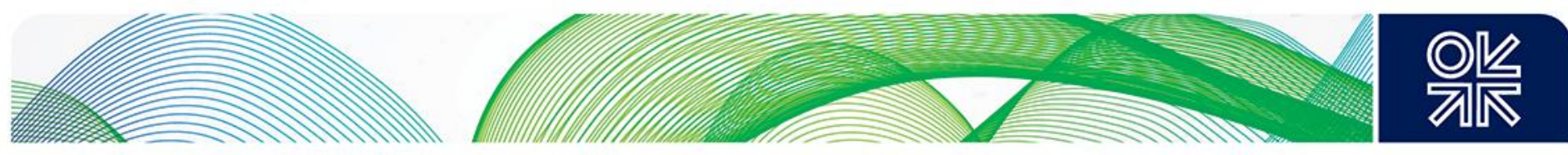

pipeline exports to China (see above). Indeed Gazprom CEO Alexei Miller has stated that his company now regards the Altai gas pipeline as more of a priority than Vladivostok LNG, ${ }^{318}$ and has also signed an initial agreement with CNPC on pipeline gas sales from Sakhalin as well, further undermining LNG plans. ${ }^{319}$ Meanwhile Rosneft's plans for a 5-10mtpa Far East LNG project, which were announced with great fanfare in 2013 as a means to use the Sakhalin 1 project's stranded gas without relying on sales to Gazprom, have been hit both by sanctions and by Rosneft's need to prioritise its investments in a low oil price environment. Therefore it seems unlikely that any LNG will be produced from the proposed scheme before 2020, as despite Rosneft's continued discussion of its LNG plans, the project is reported to have been pushed back by at least two years from its provisional 2018 start-up. ${ }^{320}$

As a result it would appear that the most likely next source of Russian LNG will be Novatek's Yamal LNG project, that is due to come online towards the end of 2017. However, doubts continue to hover over this development too, due to the fact that Novatek is on the US sanctions list with the consequence that project financing has been hard to finalise. With no western banks able to provide US dollar financing for the project, the partners have turned to Russian and Asian banks for support, and in June 2015 Sberbank, Gazprombank and Vnesheconombank, the China Development Bank and Eximbank agreed the principle terms of an agreement. ${ }^{321}$ However, until a final deal is signed the future of Yamal LNG remains uncertain, as even the Russian government, which has provided support for the project from the country's National Welfare Fund, has been reluctant to supply the final tranche of a RR150 billion loan until international project financing is agreed. ${ }^{322}$ However, the sale of 9.9\% of the project to the Chinese Silk Road Fund in September 2015 suggests that Chinese financing will ultimately be provided, ${ }^{323}$ while the $\$ 9$ billion of spending to date suggests that the project must ultimately proceed at some point. Nevertheless it must be possible that timing of first output from the three trains could be delayed beyond the planned 2017/2018/2019 schedule, but it remains probable that first LNG will be delivered to Asia at some point in 2018 from the first train, with the second and third trains perhaps each delayed by 6 months to a year.

Even with this potential delay, though, it is possible that Novatek could become Russia's largest LNG producer and exporter by the end of this decade, especially as Sakhalin 2 expansion is now likely to be delayed until 2021 at the earliest. ${ }^{324}$ This will be significant not only because it will underline the emergence of non-Gazprom players in the global gas market but also because the majority of the LNG from Yamal will be travelling west to Europe rather than east to Asia, as the weather conditions in the Northern Passage mean that LNG can travel to China during only five months of the year. As a result, the remaining gas must be transported to Europe, and although some of it will be transferred from the ice-breaking tankers for onward transport through the Suez Canal towards Asia, ${ }^{325}$ the existing contracts signed by the project partners suggest that a significant amount will remain in the Atlantic Basin. Table 9 below shows the contracts signed for LNG from the Yamal LNG project, highlighting not only that Gas Natural and Total Gas and Power are original purchasers of gas but also that Novatek Gas and Power has sold cargoes on to Shell ${ }^{326}$ and French company Engie. ${ }^{327}$ Furthermore, Gazprom itself has contracted to purchase $2.9 \mathrm{mtpa}$ for 20 years, ${ }^{328}$ and although this is 

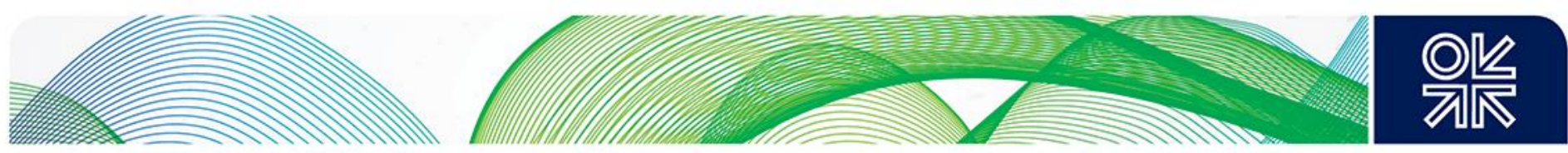

likely to be sent to India to fulfil a 3mtpa contract Gazprom has signed with GAIL it is also possible that some could end up in Europe if Indian gas demand does not meet expectations. ${ }^{329}$

Furthermore Novatek's influence on the Russian LNG business could become even greater if its plans for a second project, "Arctic LNG", located on the Gydan peninsula on the opposite side of the Ob River from Yamal LNG, come to fruition. The company already owns fields in the area that are estimated to contain almost $400 \mathrm{bcm}$ of gas, and the licences allow for LNG development under the new 2013 regulations. ${ }^{330}$ As a result Novatek's current plans see a new project being developed using the Yamal LNG model, with three $5.5 \mathrm{mtpa}$ trains for a total capacity of $16.5 \mathrm{mtpa}$ being online by the mid-2020s. The company's latest schedule sees development commencing in 2018, although this timing will presumably be dependent on the successful completion of Yamal LNG as well as on the potential impact of US and EU sanctions later in the decade.

Table 9: Yamal LNG Sales Contracts

\begin{tabular}{|l|cc|}
\hline Original Purchasers & Volume (mt) & $\begin{array}{c}\text { Duration } \\
\text { (years) }\end{array}$ \\
\hline Gas Natural & 2.50 & $\begin{array}{c}\text { Long-term } \\
\text { Gazprom }\end{array}$ \\
Novatek Gas and Power & 2.90 & $\begin{array}{c}20 \\
\text { Long-term }\end{array}$ \\
Total Gas and Power & 4.00 & Long-term \\
CNPC & 3.00 & 15 \\
Total & 15.26 & \\
Total Capacity & 16.50 & \\
\hline & & \\
Onward Sales & & \\
Novatek Gas and Power & 2.86 & \\
Shell & 0.90 & 20 \\
Engie & 1.00 & 23 \\
Total & 1.90 & \\
\hline
\end{tabular}

Sources: Reuters, Novatek, Gazprom, Shell, Engie

In partial response to this challenge from Novatek, Gazprom has announced plans to establish its own west-facing LNG scheme located on the Baltic Sea close to St Petersburg. The Baltic LNG scheme was first conceived in the mid-2000s, but was postponed due to the 2008 economic crisis. It has now been re-kindled as Gazprom seeks to expand its presence not only in the Atlantic Basin LNG market but also in South America and in the LNG bunker market in the Baltic Sea itself. ${ }^{331}$ It may also supply the Kaliningrad region of Russia, which is currently outside the reach of the trunk pipeline system. Gazprom took an investment decision on the 10mtpa project in April 2015, 332 and has committed to send out first LNG in 2020, ${ }^{333}$ but the decision does not have the weight of a full FID announcement as project financing has not been received and there has also been no announcement about potential partners for the project. Therefore, although Gazprom appears to be committed to the $\$ 18 \mathrm{bn}$ project, and it seems to be the most probable of its LNG projects after the Sakhalin 2 expansion, a level of uncertainty remains over exactly when it may finally go ahead. ${ }^{334}$

One interesting aspect of the Baltic LNG project, should it proceed, is how the LNG will be priced, as it is conceivable that it may need to compete with US LNG on a cost plus basis. Figure 25 below attempts to demonstrate how this might work in practice, using the price of gas in the Leningrad region as a starting point, ${ }^{335}$ before adding a $15 \%$ premium for shrinkage/gas purchasing, a

\footnotetext{
${ }^{329}$ Reuters, 1 Oct 2012, "Gazprom, India's GAIL agree 20-yr LNG sales deal”

${ }^{330}$ Barents Observer, 30 Jan 2014, "Novatek plans second LNG plant in Arctic"

${ }^{331} \mathrm{http}: / /$ www.gazprom.com/about/production/projects/lng/baltic-Ing/, accessed on 13 July 2015

332 Interfax, 17 Apr 2015, "Gazprom approves Baltic LNG investment decision, signs declarations with Leningrad region"

${ }^{333}$ Interfax, 26 June 2015, "Baltic LNG scheduled for completion in 2020"

${ }^{334}$ Interfax, 17 June 2015, "Baltic LNG plant, associated infrastructure to cost about 1 trln roubles - Ust Luga chief"

${ }^{335}$ Assumed to be RR3774/mcm, converted to US\$ using an exchange rate of US\$1=RR60
} 

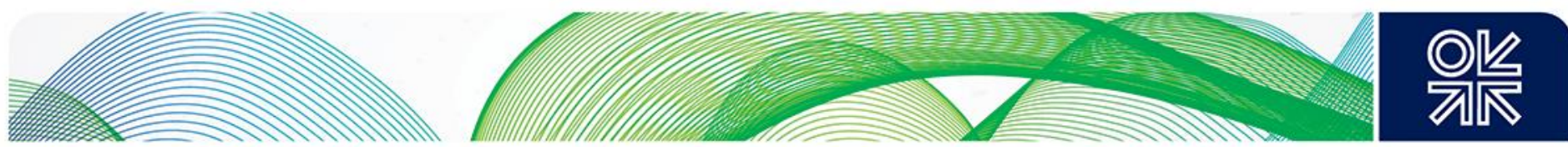

liquefaction fee of $\$ 4 / \mathrm{mmbtu}$ (given the greenfield nature of the site), a transport fee to Europe of $\$ 0.25 / \mathrm{mmbtu}$ and a regasification fee of $\$ 0.50$ (but importantly no export tax which enhances the profitability for Gazprom compared with pipeline sales). This gives a total long-run marginal cost of $\$ 6.8 / \mathrm{mmbtu}$, compared with a notional US LNG full cost (based on a Henry Hub gas price of US $\$ 3 / \mathrm{mmbtu}$ ) of $\$ 8.5 / \mathrm{mmbtu}$. It is certainly unclear whether Gazprom would be prepared to price its gas on this basis, but given that the outcome is close to some of the price levels discussed earlier which may be required to make Russian gas competitive in Europe, it is not inconceivable that a link between the Russian domestic gas price and the European export price could be established.

\section{Figure 25: Theoretical cost of supply from Baltic LNG project compared with US LNG}

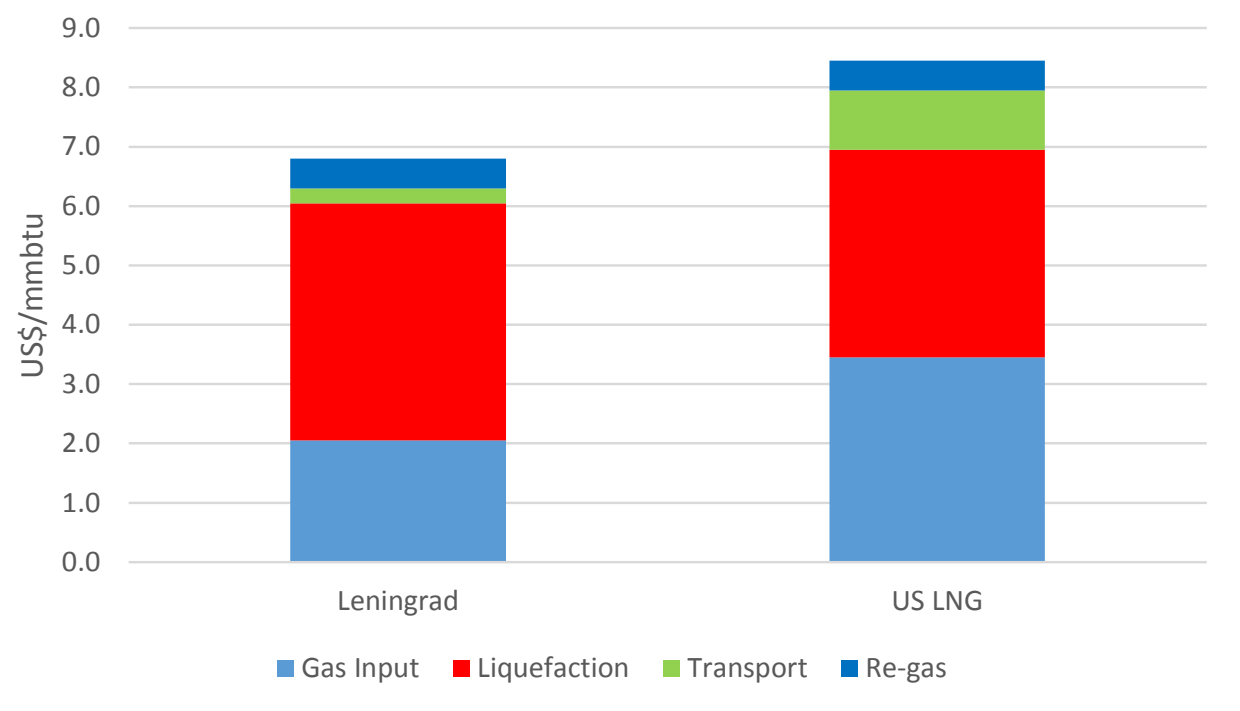

Source: Gazprom, Authors' calculations

The potential output from Baltic LNG is shown in Figure 27 below, which demonstrates that its real effect will only be felt by 2025 , when we estimate that it may be producing $5 \mathrm{mtpa}$. Indeed the overall impact of Russian LNG now appears to have been deferred until the mid-2020s at the earliest, with Sakhalin 2 expansion, Vladivostok LNG and Far East LNG all having been delayed, with the result that Yamal LNG may well be the only new project to be added to the current Sakhalin 2 production before the end of this decade. Thereafter the Sakhalin 2 expansion could still be online by 2025, if sanctions issues are resolved or if the Sakhalin 1 partners ultimately decide to sell their gas to Gazprom, while Far East LNG may proceed as and when Rosneft's financial situation improves and if it can find sufficient gas in the Sea of Okhotsk to fill a $10 \mathrm{mtpa}$, rather than the initial $5 \mathrm{mtpa}$, plant. Novatek's Arctic LNG can also move ahead if the gas reserves on the Gydan peninsula are confirmed, which seems likely, but more importantly if the Yamal LNG project proves to be a financial success and can provide the company with the cashflow to reinvest in a new project. The Russian government certainly seems to be keen to support this second Novatek scheme, having provided tax breaks similar to those offered for the company's first project. ${ }^{336}$ Vladivostok now appears more likely to proceed only by 2030, if the Power of Siberia pipeline is extended to the Pacific Coast or if gas from Sakhalin Island is freed to flow through the Sakhalin-Khabarovsk-Vladivostok pipeline. However, both of these assumptions must now be in some doubt, and so it is certainly possible that Vladivostok LNG may be postponed indefinitely. Finally the Pechora LNG project can also be developed if Rosneft can successfully persuade the Russian authorities to provide an export licence and if it can raise sufficient project financing for another Atlantic Basin LNG project. Having said this, all these latter five projects which have yet to declare FID are shown in grey in Figure 26 to indicate their uncertain

${ }^{336}$ The Moscow Times, 21 Oct 2013, "Putin orders more tax breaks for Yamal" 

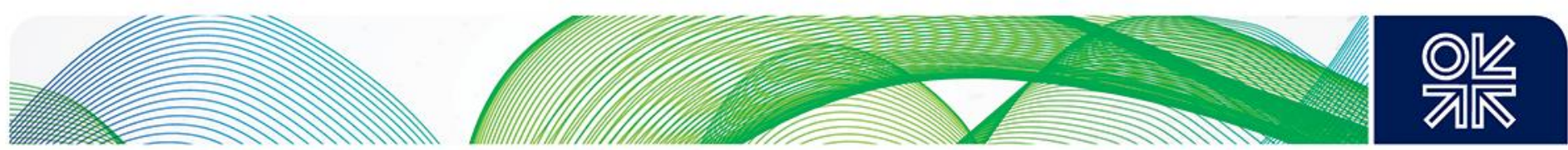

status. Finally the Shtokman project is also included in 2030, although this remains a speculative project given the technical and commercial challenges which have caused its postponement to date.

\section{Figure 26: Potential output from Russian LNG projects}

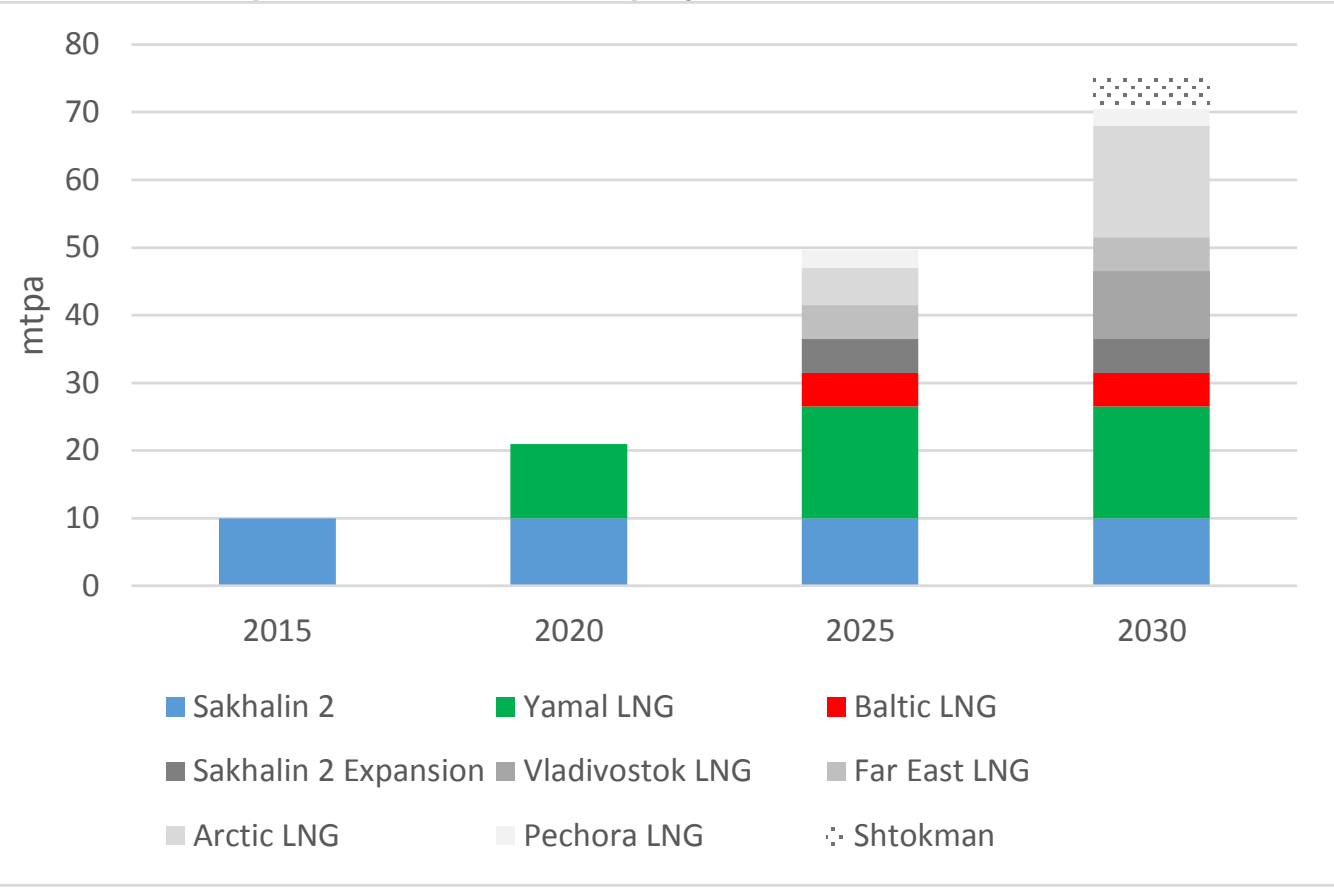

Source: Authors' calculations and estimates

Despite the slowdown in Russia's LNG plans, three important conclusions can nevertheless be drawn related to the country's export strategy. The first is that although the volumes to be exported by 2020 are likely to be less than might have been expected even two years ago, and will mainly be directed towards Asia, nevertheless the impact on Gazprom's marketing strategy in Europe could be significant. Russia's new projects could add to the global LNG oversupply over the next five to ten years, and will start to send gas into the European market either directly (from Yamal LNG and Baltic LNG) or indirectly due to other LNG being backed out of the Asian market. The implication for Gazprom is that it may have to adopt a more flexible and market-oriented marketing and pricing strategy in Europe in order to adapt to this new more flexible gas, as although the LNG may have been sold on long-term contracts its impact will nevertheless be felt in the short-term spot markets in Europe and Asia. This impact is only likely to increase beyond 2020 as more Russian LNG schemes are potentially brought onstream.

A second conclusion is that growth in Russian LNG output may open up new markets for Russian gas, but in order to achieve this exporting companies will need to market their output competitively. In emerging LNG markets such as India and South America US LNG, priced on a Henry Hub basis, is already having an impact even before the first gas has been delivered, with buyers now seeking more market-oriented pricing formulae, and in India's case gas that is cheap enough to encourage demand growth in a relatively poor economy. ${ }^{337}$ Even in the bunker market in the Baltic Sea, where LNG is competing with heavy fuel oil used by tankers and ferries, Russian gas exporters will need to find ways to incentivise ship-owners to incur the cost of investing in LNG-powered vessels rather than installing scrubbers to reduce emissions from oil-fired engines. As a result, competitive pricing will be essential, related to both competing fuels and to alternative sources of gas. 

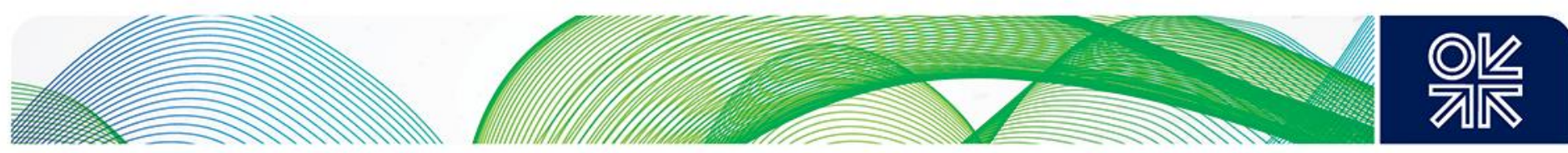

A third conclusion is that the expansion of Russian LNG exports could also imply an expansion of non-Gazprom players in the global gas market, with Novatek the key player with its Yamal-based projects. If Novatek's second scheme does go ahead, then it could be producing more than $30 \mathrm{mtpa}$ of LNG by 2025, making it a significant force in the marketplace and possibly a more important factor than Gazprom. If Rosneft's Far East LNG project also moves ahead, then more than half of Russian LNG exports could come from non-Gazprom players, even if all Gazprom's projects proceed on schedule. Although this is likely to be seen as a threat by Gazprom, it may also indicate that the Russian government understands the need for some diversity in its export strategy, not only to encourage better performance from its domestic players but perhaps also to respond to the antagonism felt towards Gazprom as a monopoly state-owned gas exporter. Although it is too early to say that this is a definitive Kremlin strategy, its support for Novatek, and to an extent Rosneft, suggests that a shift in outlook is starting to occur.

\section{Is it possible that Gazprom's pipeline export monopoly could be broken?}

A final question concerning Russia's gas export strategy might therefore be whether the presence of non-Gazprom players in the export market could be extended to pipeline sales as well as LNG. As far as the domestic market is concerned President Putin has proved to be a strong advocate of third party access on equal terms with Gazprom, going so far as to order the Russian government to develop a plan for offering non-discriminatory access in June 2014. ${ }^{338}$ However, he was also keen to support Gazprom's position in the export market, where its ownership of the UGSS trunk pipeline system provides it with an export monopoly under Russian law. The one exception to this objective, though, may be in the Far East, where the Presidential Energy Commission in June 2014 considered the possibility for non-Gazprom players, and in particular Rosneft, to be allowed access to what essentially will be an export pipeline. ${ }^{339}$

Rosneft, in tandem with its partners at the Sakhalin 1 project, has long been frustrated by its inability to market its gas in the east, having signed an export contract with China as long ago as 2006.340 However, it has been blocked by Gazprom from sending gas through the Sakhalin-KhabarovskVladivostok pipeline, which could have provided a route into north-east China. A second attempt by Rosneft has seen the company look to exploit its associated gas in East Siberia, where it has significant gas reserves, by gaining access to the Power of Siberia pipeline, when it is completed towards the end of this decade. ${ }^{341}$ The decision of the Presidential Energy Commission appeared to mark a step in this direction, with Rosneft pointing out that as the pipeline is not connected to the UGSS then Gazprom's monopoly export rights do not apply. Gazprom has responded by arguing that third party access rights for third parties who have not invested in the pipe would not apply, although it has conceded that it should allow access to associated gas, but only for use in Russia. ${ }^{342}$ Furthermore, it has argued that the gas export contract has been signed by Gazprom and CNPC, and that it sees no need for any other company's gas to be involved. ${ }^{343}$

Gazprom's hard stance on allowing access to pipelines that it has paid for and built is further exemplified by the legal dispute which it has fought with Rosneft over access to the Trans-Sakhalin pipeline, which Rosneft wanted to use to supply its Far East LNG project. Gazprom argued, at first successfully, that there would not be sufficient capacity in the pipeline should it decide to expand the Sakhalin 2 project, and a court decision in its favour led to Rosneft re-locating its planned project to a

\footnotetext{
338 Yafimava (2015) p.12

${ }^{339}$ Financial Times, 22 July 2014, "Putin suggests ending Gazprom pipeline monopoly"

340 The Moscow Times, 24 Oct 2006, "Exxon's Sakhaliln-1 signs China deal"

${ }^{341}$ Interfax, 20 May 2014, "Rosneft hopes to get assess to Power of Siberia gas pipeline"

342 Interfax, 10 Aug 2014, "Independent gas producers can supply APG for Power of Siberia pipeline"

${ }^{343}$ Interfax, 23 Sept 2014, "Gazprom says giving independents access to Power of Siberia pipeline would reduce profitability of its projects"
} 

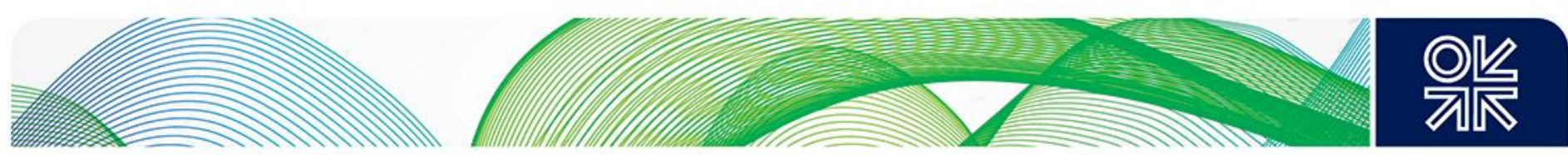

location which it can access by building its own pipeline connection. ${ }^{344}$ Interestingly in September 2015 this decision was reversed on appeal, but it remains to be seen whether this will alter Rosneft's plans given that its Far East LNG scheme already seems to have been delayed until the 2020s. ${ }^{345}$ However, it could provide a precedent for further negotiations concerning access to Gazprom pipelines in the east of Russia, with potential implications for the negotiations concerning Power of Siberia mentioned above.

Clearly, then, the debate is continuing, with uncertainty being caused not only by a lack of clarity over the exact future of Power of Siberia or Power of Siberia-2 (Altai) but also by the fact that Gazprom may indeed need some extra gas if it is unable to develop both the Chayanda and Kovykta fields on schedule. Furthermore, the fact that Power of Siberia is no longer planned to reach Vladivostok also reduces the domestic market opportunities for Rosneft and other non-Gazprom players. Nevertheless, the most likely outcome appears to be that Gazprom will retain full control over pipeline gas exports in the East, while offering some access to domestic customers close to the pipeline and in extremis perhaps offering preferential export-netback prices for third party gas if it is needed to top up its own gas production for export to China. ${ }^{346}$ Indeed Rosneft has been pushing for exactly this outcome not only in the East but also in the West, where it has previously refrained from challenging Gazprom's export rights. In July 2015, though, the company's CEO Igor Sechin launched another attempt to undermine Gazprom's position and to gain access to a share of Russia's export revenues. ${ }^{347}$

Gazprom will certainly be equally robust in defending its position in terms of access to export pipelines to Europe, which do form part of the UGSS and therefore allow it to exercise its monopoly. Until recently very little challenge had been made to Gazprom's position in the west, with Novatek providing the only suggestion of competition when it signed a deal to sell $2 \mathrm{bcma}$ of gas to German utility EnBW in 2012. ${ }^{348}$ However, this gas is supplied from the European spot market, and is seen by Novatek as preparation for marketing its Yamal LNG gas when it arrives in the continent towards the end of this decade, rather than an outright challenge to Gazprom. Indeed Putin himself has defended Gazprom's export position in Europe, with one of his aides describing Gazprom's export monopoly as "unshakeable". ${ }^{349}$ Furthermore there appears to be a consensus among Russian politicians that Russian companies should not compete with each other in the European market. ${ }^{350}$ The one possible motive for altering this position that has been suggested is to alleviate EU concerns about Russia's new pipeline plans, with third party Russian companies perhaps being allowed access to South Stream (when it still existed) and Nord Stream in order to show compliance with the Third Energy Package. However, given the deterioration of relations with Europe since, and the alternative plans that Gazprom appears to be making to adjust its strategy in Europe, this outcome no longer seems likely. Instead, Gazprom's confidence that it will remain the sole supplier of Russian pipeline gas to Europe, thereby providing both a political as well as a commercial lever for the Russian government, seems justified for the foreseeable future, with even its domestic competitor Novatek in agreement with this stance. ${ }^{351}$ The only threat is that it may eventually be forced to give up some of its export revenues to third party producers, if Rosneft's plans are accepted, although this outcome is likely to be tested in the East first before being applied to western markets, where the impact on Gazprom would be much greater.

\footnotetext{
${ }^{344}$ Interfax, 19 Feb 2015, "Court rejects Rosneft request for access to Sakhalin-2 pipe, Rosneft to appeal"

345 Interfax, 9 Sept 2015, "Court requires Sakhalin-2 operator to give Rosneft conditions for connecting to the transport system"

346 Interfax, 20 Feb 2015, "Independent cos could get access to Power of Siberia two years after launch"

347 Vedomosti, 24 July 2015, “«Роснефрть» начала новое наступление на экспортную монополию «Газпрома»"

${ }^{348}$ The Moscow Times, 16 Oct 2012, "Novatek signs deal to supply gas to Germany's EnBW"

${ }^{349}$ Reuters, 23 July 2014, "Gazprom monopoly on pipeline gas exports "unshakeable" - Putin aide"

350 Sputnik News, 28 July 2015, "Gazprom should remain monopoly for gas exports"

351 Bloomberg, 28 Mar 2014, "Novatek sees no need to end Gazprom's pipeline export monopoly"
} 

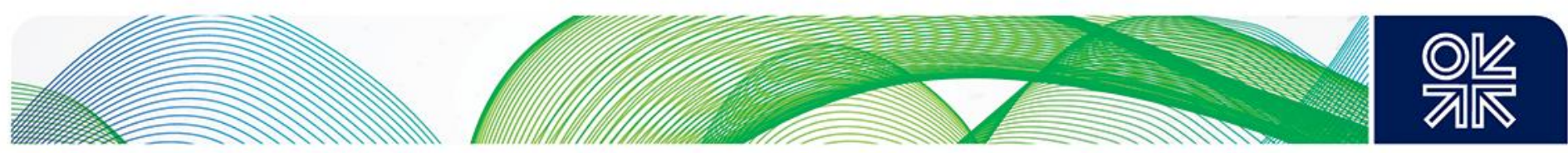

\section{Conclusions}

A variety of competitive and political forces have left Russia, and its main gas company Gazprom, in a difficult position in all of its west-facing markets at a time when significant capital expenditure has been spent on the development of a huge new gas reserve base on the Yamal peninsula in northern Siberia. Demand for its gas in Europe has stagnated due to the impact of US shale gas on the LNG market, the arrival of cheap coal imports, the increased use of renewables and the dampening effect of the economic crisis on overall gas consumption. Meanwhile exports to the FSU have fallen due both to Gazprom's strategy of increasing prices in many countries but also to the obvious impact of the political crisis in Ukraine. At home in Russia Gazprom has also come under pressure from increased competition and has seen its sales fall sharply. The combined effect of all these market forces has left the company with a surplus of supply capacity totalling as much as $100 \mathrm{bcma}$. When this commercial reality is combined with the political issue that many countries in Europe and the FSU are keen to diversify away from Russian gas, seeing it as a security risk, then it is clear that Gazprom needed to create alternative options for selling its gas, while the Kremlin has been keen to demonstrate that Russia need not be reliant on sales to countries which are currently imposing sanctions on it. However, the vast array of political as well as commercial influences on the country's gas export strategy appears to have led to a degree of improvisation that often makes it difficult to interpret the logic of individual tactics as they are frequently announced with surprising timing.

Gas sales to Asia have been contemplated by Russia since the 1990s, and firm negotiations with China have been continuing since 2004. However, it took a geo-political crisis with Europe to catalyse President Putin into action, and he became the driving force behind the May 2014 deal that saw Gazprom agree to sell gas from East Siberia into north-east China, with CNPC being the purchaser. A subsequent deal to sell gas from West Siberia via Altai into north-west China has also been signed since, although with the price still to be agreed. However, the fact that a political catalyst was needed to get the deal done highlights the fact that a number of commercial uncertainties remain, which could yet cause one or both agreements to unwind.

Primarily, the outlook for the Chinese gas supply and demand balance remains very unclear on both sides of the equation. Chinese demand has slowed recently, with forecasts for 2020 being downgraded sharply, while the future of Chinese production remains ambiguous because of the uncertainties surrounding shale gas development. As a result, the level of overall gas import requirements remains a matter of conjecture, with Russia's place within the import balance being equally indeterminate. Adding to the uncertainty is that Russia would appear to have a preference for developing the Altai export route before Power of Siberia, despite its protestations that the latter remains its priority. The Russian government has recently underlined its support for Power of Siberia, but the sense is that both the Kremlin and Gazprom are continuing to search for alternative options that can maximise the political and commercial outcome for Russia in the face of significant global market pressures. As a result, despite the signing of export agreements, an element of opportunism remains within Russian strategic thinking, based on the search for short-term as well as long-term solutions to Gazprom's current problems, with the proposal in September 2015 of a third pipeline to China from the Far East of Russia highlighting a sense of desperation and a desire to have another option on the negotiating table. A further complicating factor is that, given China's strong bargaining position, with ample import alternatives from Central Asia and an oversupplied global LNG market, there must be a significant risk that it could decide to change the terms of trade with Russia, especially if Gazprom fails to commit to its preferred export route in the East and pushes too hard for the Altai route. Russia is not without bargaining strength, as it can offer competitively priced gas in large volume, but its likely need for Chinese financing and the delicate nature of geo-political relations between the two countries means that the Kremlin is unlikely to want to become overly reliant on sales to its southern neighbour. As a result, although the pivot to Asia can provide some diversification for Russian gas exports over the longer term, it is unlikely to offer the strong insurance 

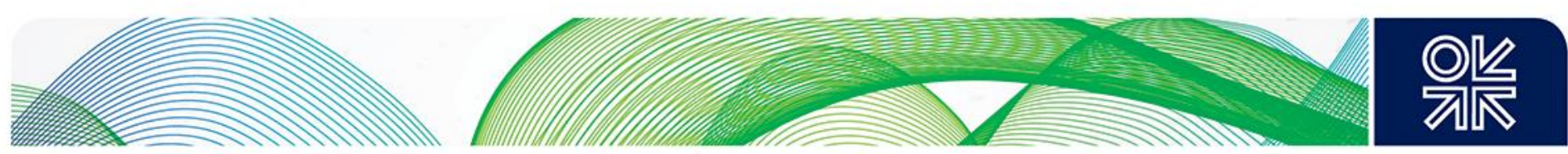

policy that Russia desires and any threat to European supply that it theoretically implied is already being seen as relatively empty. ${ }^{352}$

Therefore it seems very likely that the mutual dependency between Europe and Russia over gas imports will remain for the foreseeable future. It would appear inevitable that Europe will continue to buy significant amounts of Russian gas given both the long-term contracts in place and the lack of viable pipeline alternatives. Equally, Russia will need to continue to maintain Europe as a major export customer in order to sustain Gazprom and Kremlin revenues at a time when low oil prices and a declining economy are impacting the overall tax take. The one major disturbance to this supply picture could come from LNG imports into Europe, with a surge in output from Australia and the US potentially set to create a surplus of gas in the global market which could be priced at short-run marginal cost if producers are desperate to find customers for their output. When this supply challenge is combined with questions about the future of gas demand in Europe, Gazprom may find itself in a difficult position as it decides how to best market its gas available for export.

Gazprom has shown that it is willing to respond to competitive pressure by adjusting its price level and its contractual terms, albeit that some of these changes have been forced upon it by arbitration cases. Nevertheless, its average price in the first half of 2015 was only just above the UK spot price. However, its strategy has to date been very reactive rather than proactive as once again it has looked to find short-term solutions to immediate problems and to create multiple options for negotiating purposes rather than developing a coherent long-term strategy. In order to fend off future competition it may need to consider a more fundamental change to a market-based approach that can allow it to respond to challenges more quickly. Its leadership has indicated that the company is taking some steps in this direction, in particular in north-west Europe where hub-based pricing is most prevalent, but no specific plans have yet been spelled out.

The evolutionary and somewhat improvised nature of Gazprom's export strategy to Europe is perhaps best exemplified by its infrastructure plans, which over the past 12 months have involved a commitment to end transit through Ukraine by building the South Stream pipeline; a switch from South Stream to Turkish Stream; a commitment to sell all its Ukraine transit gas at a new Turkey/Greece hub; the announcement of an expansion of Nord Stream; an apparent uncertainty over the plans for Turkish Stream with contractor contracts being cancelled, onshore lines postponed and an intergovernmental agreement with Turkey delayed; and finally an ostensible reversal of its original Ukraine transit decision under the specific instruction of President Putin. Although the ultimate outcome may provide a reasonable commercial solution, the confusion created during the process would seem to point to Russian uncertainty over its realistic future in the European gas supply and demand balance.

The positive news for Gazprom is that if it needs to compete to maintain its position in the European gas market then it has enough low-cost supply to meet its objectives. Although the full cost of developing fields on the Yamal peninsula is high, leading to a breakeven cost of $\$ 7-10 / \mathrm{mmbtu}$ delivered to Europe, the short-run marginal cost of Russian supply is much lower at around $\$ 4 / \mathrm{mmbtu}$, thanks to low upstream costs and the benefits of rouble devaluation. At this level it can even compete with US LNG imports based on a Henry Hub price of $\$ 3 / \mathrm{mmbtu}$, meaning that on a purely commercial basis Russia could effectively choose its own market share in Europe. In reality its current target is a relatively modest $30 \%$ of European demand by 2030 , a similar market share to 2014 , although its pipeline plans suggest that it anticipates the possibility of much higher demand for its gas beyond 2020.

Given Gazprom and the Kremlin's innate confidence that Europe will need more Russian gas (even if it does not want it), the clear preference in terms of pricing strategy is to maintain the status quo as far as possible, and statements defending long-term oil-linked contracts have been made many times by Gazprom representatives. However, what is also clear is that EU legislation, and in particular the Third Energy Package are having a significant impact on Gazprom's strategy, while the activities of

${ }^{352}$ Atlantic Council, 7 July 2014, “Don't Panic: Russia's energy pivot to Asia and European energy security” 

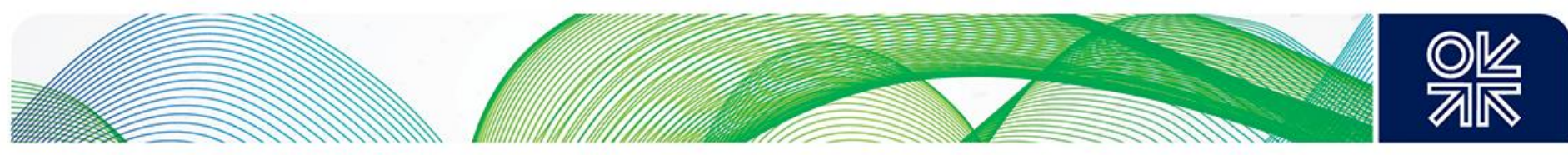

the European Commission in investigating Gazprom's activities in eight Central and Eastern European countries are also causing the company to reassess its position. Indeed Europe is arguably developing a powerful strategy to counter its dependence on Russian gas, by forcing Gazprom to compete more actively and to withdraw from downstream activities. Gazprom appears to be increasingly keen to sell its gas on the borders of Europe, and has initially offered sales at new hubs such as on the Turkish border or in St Petersburg. However, the reversal of its decision on the BASF/Wingas asset swap demonstrates that this strategy is certainly not set in stone, and as such we are probably only seeing the opening gambits in a negotiating process which will continue for the next four years, until the Ukraine transit contract expires in 2019.

This period of negotiation will be continuing during a time when the increasing oversupply of LNG in the global gas market will inevitably create a buyers' market, further strengthening the hand of the EU. Gazprom has demonstrated that, although it would prefer the status quo to remain, it is preparing to respond to change and competition by altering its pricing methodology and contractual terms, and an important question is whether it might adopt a strategy of creating a period of low gas prices in Europe in order to disincentivise new supply from coming online. We believe that a price crash scenario is unlikely, as it entails too much risk for Gazprom and the Kremlin in the short term, but we do not rule out a more volatile price environment as the company attempts to exert some control over market outcomes. From a European perspective, though, this can be a positive indication that its strategy of diversification through market forces is working. It seems inevitable that the continent will remain reliant on Russian gas for the foreseeable future, but it can avoid dependence on Russian gas by continuing its current strategy of creating supply alternatives that are available via interconnections across Europe in order to ensure that countries which are most dependent on Russian gas can develop robust diversification strategies, thus forcing Gazprom to compete with the lowest cost alternative in the major European markets. Furthermore, that lowest cost alternative would be available in the extreme circumstance of a supply interruption, although we regard this as a very low probability event given Russia's export history.

During 2015 solid evidence as to the direction of Russia's evolving gas export strategy could be provided as the negotiations with DG COMP over the latter's Statement of Objections are concluded and also as existing long-term contracts come up for re-negotiation. The most interesting of these in 2015 will be the small, but politically sensitive, contracts with Lithuania and Estonia, which are due to expire at the end of the year. ${ }^{353}$ Both countries are taking a relatively relaxed attitude to the talks with Gazprom, as for the first time they have some bargaining power, following the construction of the LNG import terminal at Klapeida and the announcement that a second regional regasification terminal may be built in Finland in the next few years. ${ }^{354}$ Indeed Lithuanian ministers have stated that "we will have an agreement with Gazprom only if they change the price formula, if it will be a spot price and if they participate equally with others in the market," ${ }^{355}$ and Gazprom's response to this challenge will be instructive for its customers across Europe, especially those in Poland, and potentially Croatia, who will also soon have access to LNG imports.

This new level of competition is, of course, exactly the outcome that the European Commission hoped to achieve with the Third Energy Package, and the investigation by DG COMP into Gazprom's historic practices may also catalyse change when the negotiations restart in September 2015. Both sides have been very cautious in their statements to date, and so it is difficult to draw definitive conclusions, but the fact that Gazprom in particular has not aggressively leapt to its own defence, preferring to take a more calm and measured approach in its response, suggests that it may well agree with, or at least accept, the direction of travel that the EU is encouraging. The question of the timing of further moves towards a more market-based strategy will be driven by a number of other factors over the next few years: the likely arrival of the first US LNG in Europe at the end of 2015; the outcome of the climate change talks in Paris in December 2015; the renegotiation of gas contracts with MOL, OMV, ENI and

\footnotetext{
${ }^{353}$ Reuters, 21 Oct 2014, "We can survive without Russian gas now, says Lithuania's energy minister"

${ }^{354}$ Interfax, 19 Nov 2014, "Finland and Estonia to bridge Baltic with gas"

355 Reuters, 21 Oct 2014, "We can survive without Russian gas now, says Lithuania's energy minister"
} 

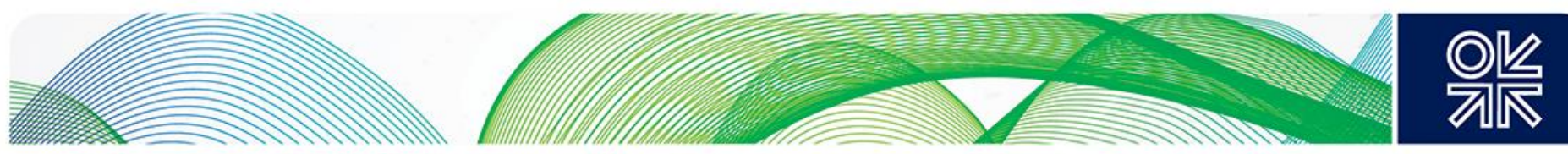

Edison before 2020; the decision over gas transit through Ukraine after 2019; the ultimate outcome for the planned Turkish Stream and Nord Stream 3 \& 4 pipelines; the price of oil; and perhaps most importantly the progression of the conflict in Ukraine, which could insert an overwhelming political dynamic into the commercial discussions. Overall, though, this succession of events would suggest that, although there is unlikely to be a sudden announcement about Gazprom's new export strategy in Europe, the gradual momentum towards a more market-oriented, hub-based, trading-driven strategy seems clear and logical. The main uncertainty surrounds the relatively short-term and improvised nature of both Gazprom and the Kremlin's decision making in the Asian and European markets, where the search for immediate solutions can create confusion over long-term goals. Nevertheless, history would suggest that in the end the logical commercial outcome does ultimately prevail, and in this case that would appear to be a more competitive and market-based gas export strategy, which Gazprom seems to be edging towards as it seeks the position that it believes it deserves in the global gas market. Indeed if it can achieve this shift in strategy then it is not inconceivable that, even assuming a relatively modest sales to Europe, Gazprom could in total be exporting considerably more than $200 \mathrm{bcma}$ by the mid-2020s (see Figure 27), rising to $280 \mathrm{bcm}$ by 2030 , at which point the contribution of the Russian independent sector in the LNG market could take Russia's overall gas export to almost 350bcma, double the level seen in 2013.

Figure 27: Estimate of potential Russian pipeline and LNG gas exports to 2030

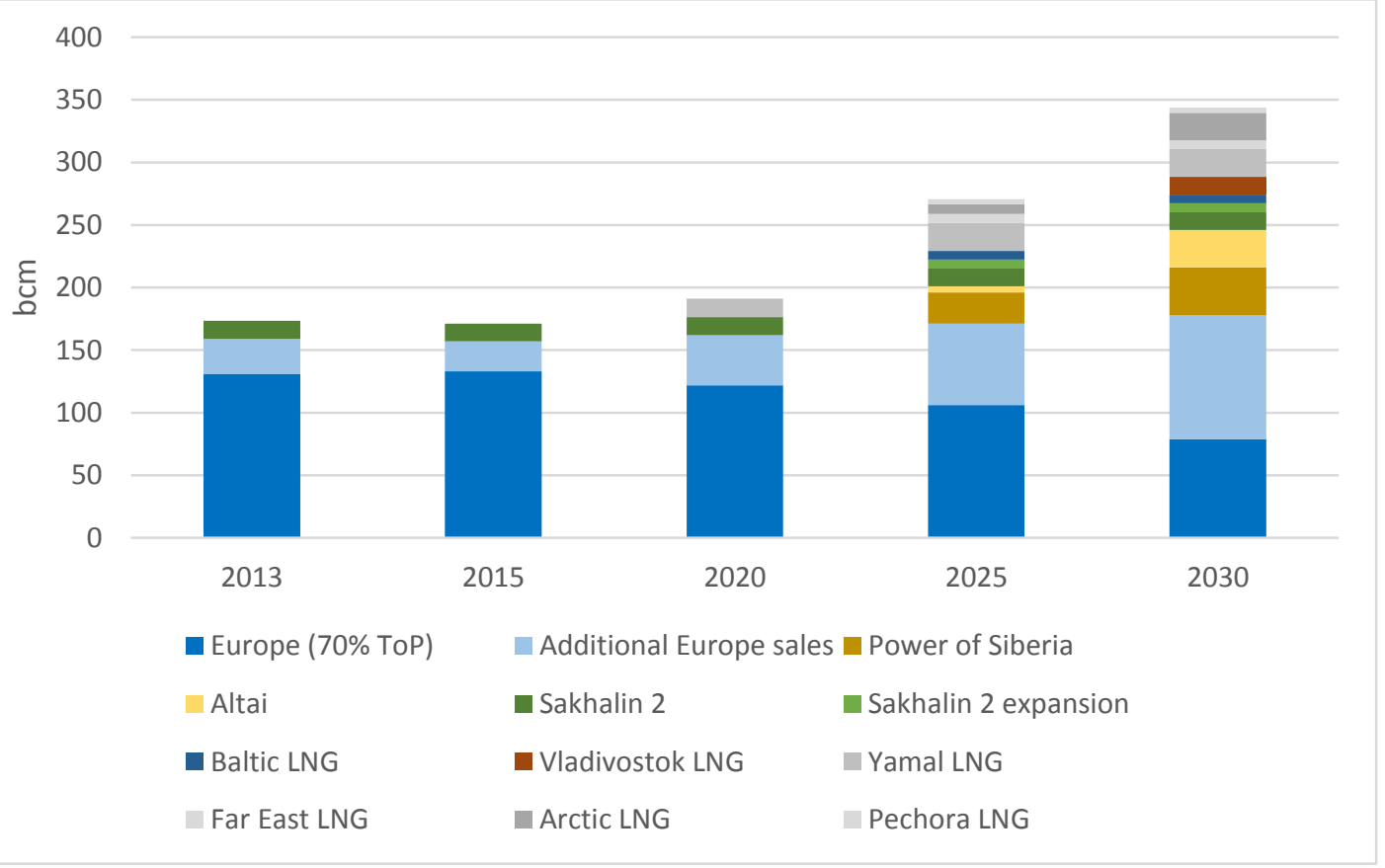

Source: Authors' estimates

One final conclusion on Russia's export strategy concerns its plans for LNG. Although many of its planned projects are likely to be delayed, nevertheless the entry of Russian LNG into the world market in the 2020s will further encourage competitive pricing as all the companies involved will need to fight for a place in an increasingly inter-connected market. Furthermore, the introduction of independents such as Novatek as major players in Russia's export strategy could see a new attitude towards gas marketing that could not only expand the global reach of Russian gas but also impact its pricing strategy in its existing pipeline-based markets. Indeed it may ultimately be the case that LNG exports could be the catalyst for a transformation in the Russian gas sector over the longer term that might see Gazprom either adapt its strategy or start to lose its place as Russia's dominant gas company. 

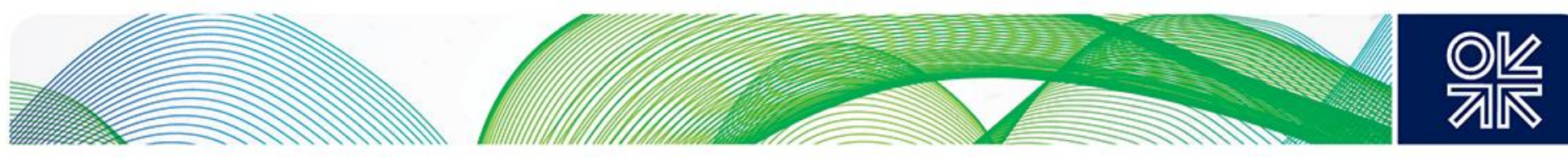

\section{Bibliography}

Arsov, Z \& Liu, L. (2012) "Natural Gas in China - potential for long-term oversupply?" Taylor Dejongh

Bordoff, J. \& Houser T. (2014) American Gas to the Rescue?: The impact of US LNG exports on European security and Russian foreign policy Centre on Global Energy Policy, Columbia University, New York

Buchan, D. \& Keay, M. (2015) Europe's “Energy Union” plan: a reasonable start to a long journey Oxford Energy Comment, Oxford Institute for Energy Studies, Oxford

Cedigaz (2014) Gas and Coal Competition in the EU Power Sector Paris

Chen, M. (2014) The Development of Chinese Gas Pricing Working Paper NG-89, Oxford Institute for Energy Studies, Oxford

Cornot-Gandolphe, S. (2014) China's Coal Market: Can Beijing Tame "King Coal"? Working Paper CL-1, Oxford Institute for Energy Studies, Oxford

EIA (2013) International Energy Outlook 2013 Washington, USA

Gao, F. (2012) Will there be a shale gas revolution in China by 2020? Working Paper NG-61, Oxford Institute for Energy Studies, Oxford

Heather, P. (2012) Continental European Gas Hubs: Are they fit for purpose? Working Paper NG-63, Oxford Institute for Energy Studies, Oxford

Henderson, J. (2011a) The Strategic Implications of Russia's Eastern Oil Resources WMP-41, Oxford Institute for Energy Studies, Oxford

Henderson, J. (2011b) The Pricing Debate over Russia Gas Exports to China Working Paper NG-56, Oxford Institute for Energy Studies, Oxford

Henderson, J. (2014) The Commercial and Political Logic for the Altai Pipeline Oxford Energy Comment, Oxford Institute for Energy Studies, Oxford

Henderson, J. (2015) Competition for Customers in the Evolving Russian Gas Market Europe-Asia Studies 67:3, pp.345-369

Henderson, J. (2015) Key Determinants for the Future of Russian Oil Production and Exports Working Paper WPM 58, Oxford Institute for Energy Studies, Oxford

Henderson, J. \& Stern, J. (2014) The Potential Impact on Asia of Russia's Eastern Gas Strategy Oxford Energy Comment, Oxford Institute for Energy Studies, Oxford

Henderson, J. \& Pirani, S. (2014) The Russian Gas Matrix: How Markets are Driving Change Oxford University Press for the Oxford Institute for Energy Studies

Hogselius, P. (2013) Red Gas: Russia and the Origins of European Energy Dependence Palgrave Macmillan, New York

Honore, A. (2014) The Outlook for Natural Gas Demand in Europe Working Paper NG-87, Oxford Institute for Energy Studies, Oxford

IEA (2013) World Energy Outlook 2013 OECD, Paris

IEA (2014) World Energy Outlook 2014 OECD, Paris

IEA (2015) Medium Term Gas Report 2015 OECD, Paris

IRENA (2015) Renewable Power Generation Costs in 2014 Bonn, Germany

Krutikin, M. (2015) Трубы на траве: что происходит с «Турецким потоком» Carnegie

Endowment for World Piece, Moscow Centre, Moscow 

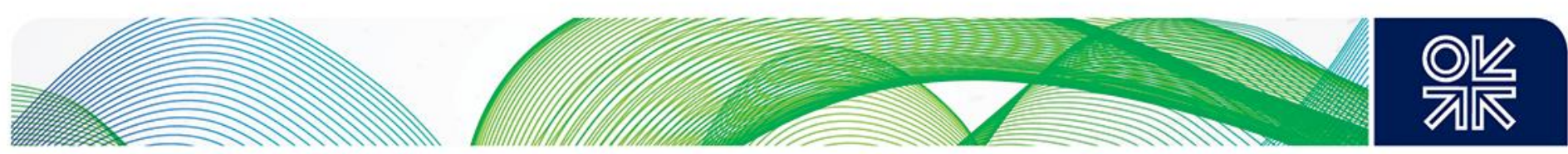

Lazard (2014) Lazard's Levelised Cost of Energy Analysis - Version 8.0 Lazard, London

Melling, J.M. (2010) Natural Gas Pricing and its Future: Europe as the Battleground Carnegie Endowment for International Peace, Washington

Mitrova, T. (2013) Russian LNG: The Long Road to Export IFRI Russia/NIS Research Centre, Paris

Mitrova, T. (2015) Changing Gas Price Mechanisms in Europe and Russia`s Gas Pricing Policy IAEE Antalya Special Issue 2015, pp. 39-40

Mitrova, T., Kulagin, K., Galkina, A. (2015) The transformation of Russia's gas export policy to Europe Proceedings of the Institute of Civil Engineers

O'Sullivan, S. (2013) China Gas: The price is becoming right Trusted Sources Research, London

Paik, K-W (2012) Sino-Russia Oil and Gas Cooperation: The reality and implications Oxford University Press for the Oxford Institute for Energy Studies, Oxford

Paik, K-W. (2015) Sino-Russian Oil and Gas Co-operation: Entering into a New Era of Strategic Partnership? Working Paper WPM-59, Oxford Institute for Energy Studies, Oxford

Pirani, S. (2007) Ukraine's Gas Sector Working Paper NG-21, Oxford Institute for Energy Studies, Oxford

Pirani, S., Stern, J., Yafimava, K. (2010) The April 2010 Russo-Ukrainian gas agreement and its implications for Europe Working Paper NG 42, Oxford Institute for Energy Studies, Oxford

Pirani, S. (2012) Central Asian and Caspian Gas Production and the Constraints on Export Working Paper NG-69, Oxford Institute for Energy Studies, Oxford

Pirani, S., Stern, J. \& Yafimava, K. (2009) The Russo-Ukrainian gas dispute of January 2009: a comprehensive assessment Working Paper NG-27, Oxford Institute for Energy Studies, Oxford

Pirani, S., Stern, J. \& Yafimava, K. (2009) The April 2010 Russo-Ukrainian gas agreement and its implications for Europe Working Paper NG-42, Oxford Institute for Energy Studies, Oxford

Pirani, S., Henderson, J., Honore A., Rogers, H. \& Yafimava, K. (2014) What the Ukraine crisis means for gas markets Oxford Energy Comment, Oxford Institute for Energy Studies, Oxford

Rogers, H. (2015) The Impact of Lower Gas and Oil Prices on Global Gas and LNG Markets Working Paper NG-99, Oxford Institute for Energy Studies

Ryazeva G. (2015) The Outlook for Azerbaijani Gas Supplies to Europe: Challenges and Perspectives Working Paper NG 97, Oxford Institute for Energy Studies, Oxford

Stern, J. (2007) Is there a rationale for the continuing link to oil product prices in Continental European long term gas contracts? Working Paper NG-19, Oxford Institute for Energy Studies

Stern, J. (2009a) Future Gas Production in Russia: is the concern about lack of investment justified? Working Paper NG-35, Oxford Institute for Energy Studies, Oxford

Stern, J. (2009b) Continental European Long-Term Gas Contracts: is a transition away from oil product-linked pricing inevitable and imminent? Working Paper NG-21, Oxford Institute for Energy Studies, Oxford

Stern, J. \& Rogers, H. (2013) The Transition to Hub-Based Pricing in Continental Europe: A Response to Sergei Komlev of Gazprom Export Oxford Energy Comment, Oxford Institute for Energy Studies

Stern, J. \& Rogers, H. (2014a) Challenges to JCC Pricing in Asian LNG Markets Working Paper NG81, Oxford Institute for Energy Studies, Oxford 

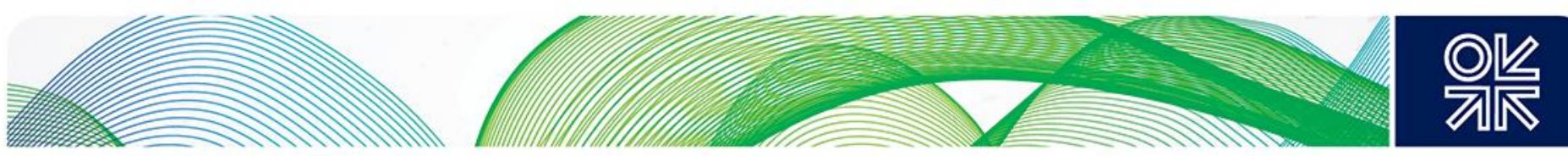

Stern, J. \& Rogers, H. (2014b) The Dynamics of a Liberalised European Gas Market: Key determinants of hub prices, and roles and risks of major players Working Paper NG-94, Oxford Institute for Energy Studies, Oxford

Stern et al (2014c) Stern, J., Dickel, R., Hassanzadeh, E., Henderson, J., Honore, A., El-Khatiri, L., Pirani, S., Rogers, H., Yafimava, K., Reducing European Dependence on Russian Gas: distinguishing natural gas security from geopolitics Working Paper NG-92, Oxford Institute for Energy Studies, Oxford

Stern, J., Pirani, S. \& Yafimava, K. (2015) Does the cancellation of South Stream signal a fundamental reorientation of Russian gas export policy? Oxford Energy Comment, Oxford Institute for Energy Studies, Oxford

Timera Energy (2015) European Gas versus Coal Plant Switching sourced from http://www.timeraenergy.com/content/uploads/2015/03/Timera-gas-v-coal-switching-190515.pdf on 26 August 2015

Yafimava, K. (2013) The EU Third Package and the Gas Target Model: major contentious issues inside and outside the EU Working Paper NG-75, Oxford Institute for Energy Studies, Oxford

Yafimava, K. (2015) Evolution of gas pipeline regulation in Russia: third party access, capacity allocation and transportation tariffs Working Paper NG-95, Oxford Institute for Energy Studies, Oxford 